Editora Poisson

\title{
Meio Ambiente em Foco Volume 4
}

\author{
1a Edição
}

Belo Horizonte

Poisson

2019 
Editor Chefe: Dr. Darly Fernando Andrade

\section{Conselho Editorial}

Dr. Antônio Artur de Souza - Universidade Federal de Minas Gerais

Ms. Davilson Eduardo Andrade

Dr. José Eduardo Ferreira Lopes - Universidade Federal de Uberlândia

Dr. Otaviano Francisco Neves - Pontifícia Universidade Católica de Minas Gerais

Dr. Luiz Cláudio de Lima - Universidade FUMEC

Dr. Nelson Ferreira Filho - Faculdades Kennedy

Ms. Valdiney Alves de Oliveira - Universidade Federal de Uberlândia

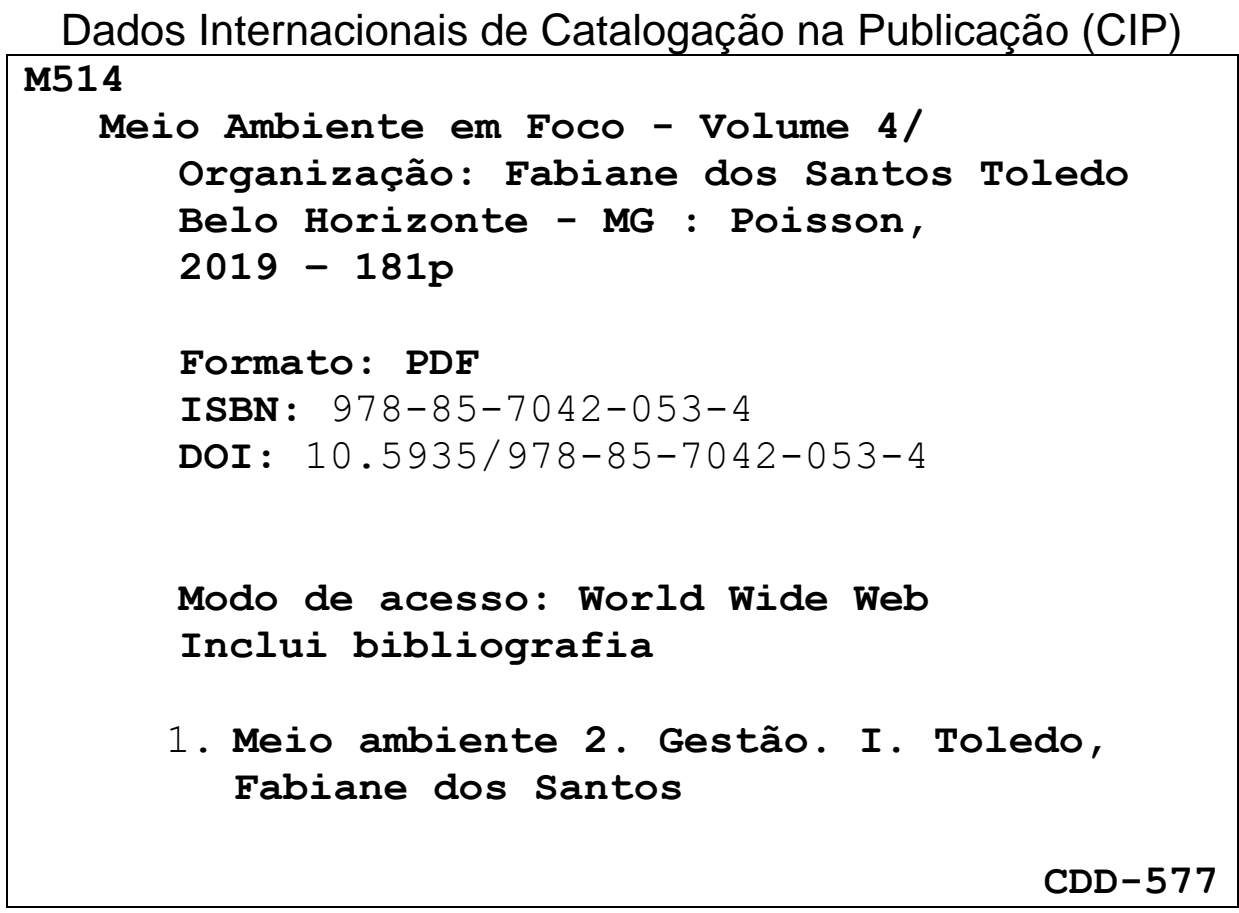

O conteúdo dos artigos e seus dados em sua forma, correção e confiabilidade são de responsabilidade exclusiva dos seus respectivos autores.

Baixe outros títulos gratuitamente em www.poisson.com.br

contato@poisson.com.br 


\section{APRESENTAÇÃO}

Há uma exigência imperiosa em ligarmos as relações humanas com as bases da sustentabilidade para a vida em nosso planeta. Ressignificar, no sentido de atribuir o que se conhece à nossa visão sobre o meio do qual somos integrantes, é um dos caminhos para a percepção ambiental mais eficiente e ativa em prol da educação e da qualidade de vida que constitui a essência de qualquer ser vivo. Para tal, requer-se mudar as perspectivas e alterar os resultados, além das escolhas e dos comportamentos.

Formar entendimento e conectar o ser humano com o meio ambiente apazigua e restaura os valores, as escolhas e as atitudes ambientais, transformando a sociedade e a cultura além das necessidades. É com esse viés que se pode chegar à tomada de consciência e às mudanças significativas.

Ao ampliarmos os conhecimentos e levá-los adiante cumprimos com o desafio de coordenar a riqueza ambiental do país de forma mais equitativa e descentralizada, assegurando a reflexão e o debate com justiça socioambiental. Desenvolvendo, portanto, a clareza do papel de cada um nesse processo.

Alinhar ao que o caro leitor espera, surpreendê-lo e estimulá-lo a compartilhar com o maior número de pessoas, desde estudantes, profissionais, a tomadores de decisões, se propaga nas próximas páginas, recheadas de bons conteúdos, comprometimento dos autores e amplas vias de conhecimento.

Aproveite a leitura!

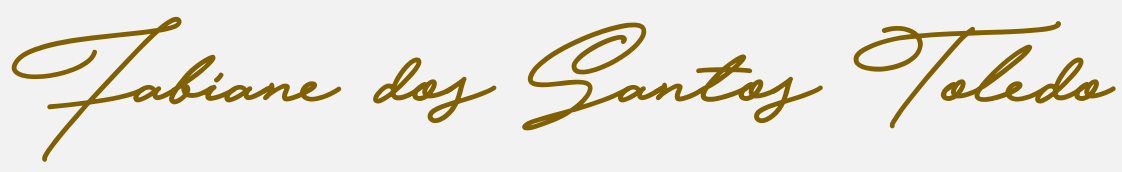




\section{Sumárīo}

Capítulo 1: Estudo de caso sobre possível contaminação do solo devido ao abandono de vagões no município de Iperó/SP.....

Andressa Corrêa Leite, Beatriz Isabella da Silva Pereira, Juliana de Carvalho Pedroso Silva, Maria Caroline Alves de Almeida

Capítulo 2: Identificação dos impactos ambientais associados à cobertura e uso da terra no município de Brotas de Macaúbas (BA)

Niédja Sodré de Araújo, Dária Maria Cardoso Nascimento

Capítulo 3: Evolução temporal do uso e ocupação do solo no município de Itamaraju - BA entre 1990 e 2013

Giovanna França Bispo da Gama, Gabriela Mateus de Fontes Silva, Thiara Helena Mota Almeida, João Batista Lopes da Silva

Capítulo 4: Relações de biodiversidade da fauna edáfica no solo da reserva extrativista do Rio Ouro Preto-RO

José Rodolfo Dantas de Oliveira Granha, Jorge Luiz Heráclito de Mattos, Ana Lucy Caproni, Alan da Silva Sampaio, Léo da Silva Sampaio, Ricardo Luis Louro Berbara

Capítulo 5: Biodiversidade da fauna do solo em três plantios de cana-de-açúcar em Itapira/SP

José Rodolfo Datas de Oliveira Granha, Ana Lucy Caproni, Jorge Luiz Heraclito de Mattos, Sander Luis Stelal, Marina Granha Vieira

Capítulo 6: Mudanças no uso do solo, cobertura vegetacional e estrutura da paisagem no entorno da Estação Ecológica de Fechos - MG.

Luciana Eler França, Lourdes Manresa Camargos, Luiza Cintra Fernandes, Fernando Figueiredo Goulart

Capítulo 7: Condutância estomática, fotossíntese e transpiração de eucalyptus sob condições de déficit hídrico

Renata Teixeira de Almeida Minhoni, Glaucia Regina Santos, Ana Clara de Barros, Ana Paula Leite

Capítulo 8: Evolução dos planos de manejos florestais aprovados e implantados no estado de Mato Grosso no período de 2000-2014

Alessandra Maria Filippin dos Passos, Aumeri Carlos Bampi 


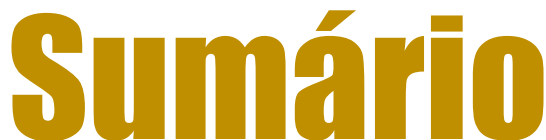

Capítulo 9: Uso de extratos naturais como inibidores de corrosão para o aço AISI 304 84

Juliana Araujo da Silva, Graziella Sarpe Capo, Maurício Masaru de Souza Ribeiro, Maurício Marques Pinto da Silva

Capítulo 10: Perfil de uso de agrotóxicos no povoado Cangandú, Arapiraca Alagoas 90

Helane Carine de Araújo Oliveira, Aldenir Feitosa dos Santos, João Gomes da Costa, Jessé Marques da Silva Júnior Pavão, Maxwel Costa de Amorim

Capítulo 11: Interações entre a cantaxantina e componentes celulares: Possíveis mecanismos toxicológicos

Marina Matos Souto, Marta Maciel Dudus, Raiane Fonseca Silva Herdy, Xiaoxin Wu, Juliana Tomaz Latini, Kátia Calvi Lenzi de Almeida

Capítulo 12: Sistema de produção de biogás para aproveitamento de resíduos orgânicos em navios mercantes

Stéfany Larissa Dantas Nascimento, Diego Leon da Silva Monteiro, Kevin Harley Ferreira Moura, Pedro Rodrigues Bozi Ferrete

Capítulo 13: Aumento da produção de metano no biogás a partir da codigestão de lodo de esgoto com diferentes tipos de resíduos. 103 Janaína dos Santos Ferreira, Isaac Volschna Junior, Magali Christe Cammarota

Capítulo 14: Potencial biotecnológico de bactérias isoladas de biodigestor anaeróbio

Angela Cristina Mélo-Schlub, Vânia Kelly da Silva, Alessandra Lee Barbosa Firmo, Leonor Alves de Oliveira da Silva

Capítulo 15: Avaliação do processo de eletrocoagulação aplicado à remoção de fósforo em reatores aeróbios.

André Aguiar Battistelli, Maria Eliza Nagel Hassemer, Naiara Mottim Justino, Flávio Rubens Lapolli

Capítulo 16: Avanços e retrocessos da atualização da instrução normativa sobre o gerenciamento de resíduos sólidos de saúde com foco nos resíduos

medicamentosos 124

Renata Oliveira Luís, Hygor Aristides Victor Rossoni 


\section{Sumárīo}

Capítulo 17: Carnaval de Manaus: A destinação final dos resíduos sólidos produzidos no desfile das escolas de samba do grupo especial

Davi do Socorro Barros Brasil, Flávia Karenine Silva da Ponte, Tales Vinicius Marinho de Araújo, Anne Marcelle Guimarães Sales, Júlio Fabricio Soares Furtado Belém, Helen Rita Menezes Coutinho

Capítulo 18: Proposição de indicadores para avaliação de impactos ambientais causados por resíduos de estações de tratamento de esgoto sanitário

Poliana Arruda Fajardo, Nemésio Neves Batista Salvador, João Sérgio Cordeiro

Capítulo 19: Avaliação das percepções, dos valores e das dificuldades de uma coleta seletiva de lixo no município de Inhumas-GO 145 João Baptista Chieppe Júnior, Gustavo Henrique Amaral Monteiro Rocha, Natasha Camilo da Silva Oliveira, Marcela Amorim da Silva

Capítulo 20: Levantamento de aspectos e impactos ambientais aplicado aos ecossistemas de ilhas e oceânicos 154

Tális Pereira Matias, Talita Vieira Maywald Prata, Adriana Maria Imperador

Autores: 


\section{Capítulo 1}

\section{ESTUDO DE CASO SOBRE POSSÍVEL CONTAMINACZ̃OO DO SOLO DEVIDO AO ABANDONO DE VAGÕES NO MUNICIPIO DE IPERÓ/SP}

\section{Andressa Corrêa Leite}

Beatriz Isabella da Silva Pereira

Juliana de Carvalho Pedroso Silva

Maria Caroline Alves de Almeida

Resumo: Sabemos que o solo é um receptor limitado de materiais descartáveis, principalmente se tratando de restos de ferragens e de resíduos anteriormente transportados pelos vagões. Este trabalho tem a intenção de esclarecer e demonstrar o estudo de caso referente ao abandono de vagões no município de Iperó/SP, bem como o processo de contaminação e seus respectivos resultados. Através de caminhamento no entorno da Estação Ferroviária, foi realizado um levantamento sobre o uso e ocupação do solo, indicios visuais de contaminação e contabilização dos vagões abandonados. Sondagens foram utilizadas para a coleta de amostras de solo para análise de metais, e com Boletins de Ocorrências e Relatórios elaborados pela Secretaria Municipal da Saúde, foi realizado levantamento sobre as questões Segurança e Saúde. O estudo de caso de áreas contaminadas demonstra a constante preocupação em minimizar os impactos que tais situações podem causar a saúde, segurança e ao ambiente de uma população, principalmente em determinados centros urbanos. Embora os resultados dos laudos tenham sidos negativos para contaminação, foram encontradas grandes quantidades de metais pesados, devido a exposição dos vagões e produtos contidos neles.

Palavras-chave: Saúde. Segurança. Metais. Meio Ambiente. 


\section{INTRODUÇÃO}

O abandono de vagões é um fato que ocorre em diversas cidades de pequeno e médio porte que possuem linhas férreas atravessando seu território, o que ocasiona problemas tanto para a população quanto ao meio ambiente. O município de Iperó, localizado na Região Metropolitana de Sorocaba/SP, com cerca de 33 mil habitantes. (IBGE, 2015), sofreu consequências desse abandono.

Com a expansão e retificação de diversos trechos da malha ferroviária, devido ao aumento dos transportes de carga e passageiros, a Estação Ferroviária de Iperó foi abandonada durante anos, sendo castigada pelo tempo e vandalismo. Consequentemente vagões foram abandonados ao redor do prédio, num dos maiores pátios da EFS Estrada de Ferro Sorocabana, totalizando em torno de cinco hectares de área. A situação se agravou após a privatização da Empresa responsável pela EFS, no fim da década de 1990, o que prejudicou os munícipes na questão saúde e segurança com a proliferação de doenças e aumento da criminalidade local, e a questão ambiental com a possível contaminação do solo, verificada através de indícios de vazamentos de produtos transportados nos vagões, devido ao desgaste e exposição dos mesmos por um longo período.

Através de laudos solicitados pela Prefeitura Municipal, foi constatado que os vagões abandonados no pátio da Estação Ferroviária transportavam combustíveis, óleo diesel, massa asfáltica, óleo BPF (Baixo Ponto de Fluidez), entre outros produtos químicos. O eventual desgaste dos vagões e a exposição de materiais deixados no interior dos mesmos configuraram uma fonte de contaminação, uma vez que todos se encontravam a céu aberto. Área contaminada pode ser definida como uma área, local ou terreno onde há comprovadamente poluição ou contaminação causada pela introdução de quaisquer substâncias ou resíduos que nela tenham sido depositados, acumulados, armazenados, enterrados ou infiltrados de forma planejada, acidental ou até mesmo natural (CETESB, 2001).

No ano de 2013, após diversos processos judiciais, a Prefeitura Municipal obteve uma liminar para a retirada dos vagões, saindo vitoriosa da grande "Guerra dos Vagões" que havia se formado.

Com o objetivo de aprofundar o conhecimento sobre o caso dos vagões bem como o processo de contaminação e seus respectivos resultados, foi realizado o estudo de caso.

Figura 1 - Pátio de Vagões (2012)

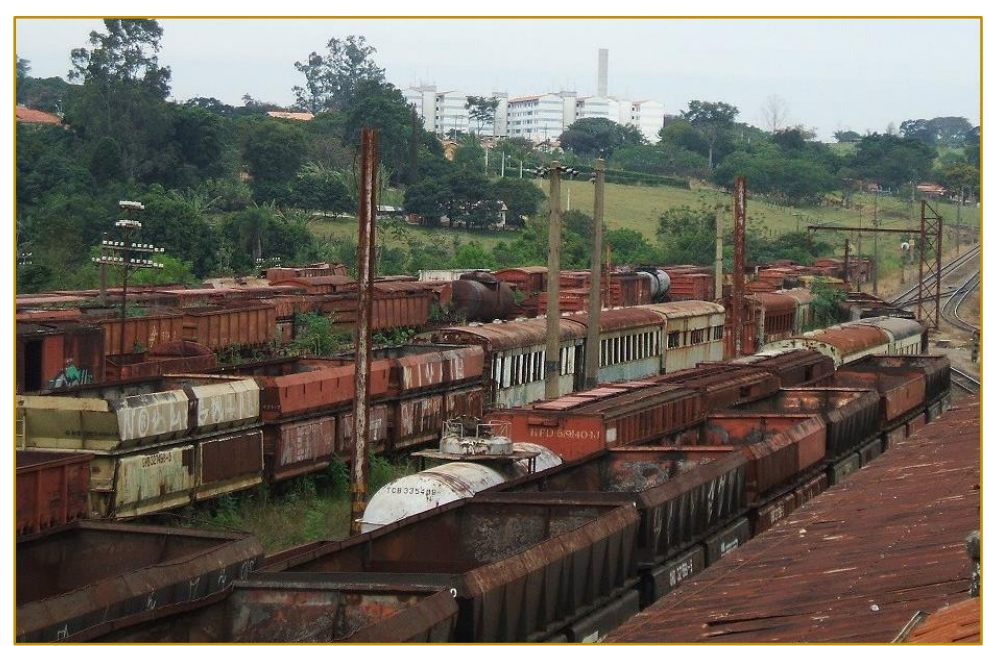

(Paulo Sérgio Vieira Filho) 
Imagem 2 - Pátio de Vagões (1990)

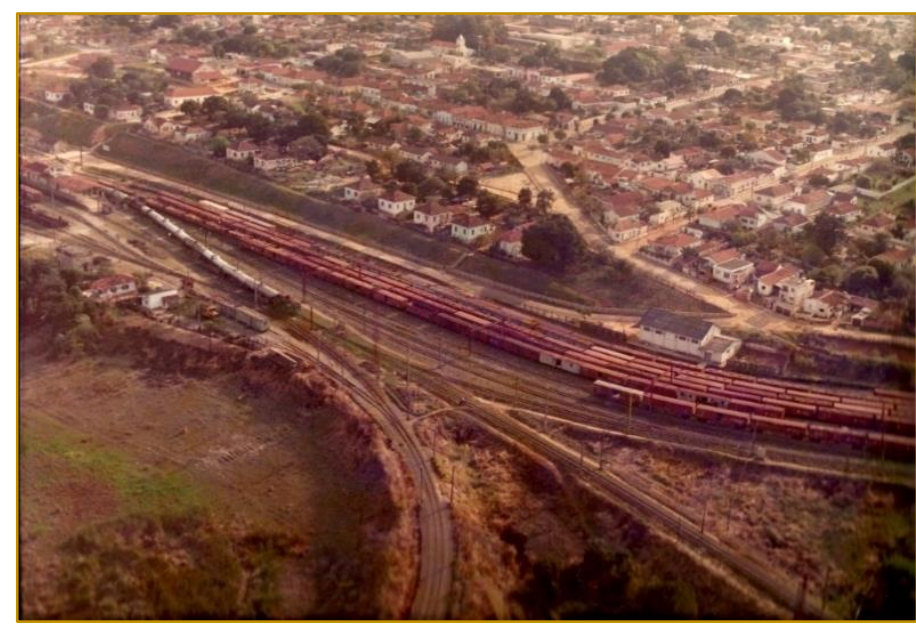

(José Roberto Moraga Ramos)

\section{MATERIAIS E MÉTODOS}

Foram realizadas a caracterização do uso e da ocupação do solo, identificação da existência de possíveis poços de captação de água subterrânea, contabilização dos vagões abandonados e inspeção de eventuais indícios visuais de contaminação, por meio de caminhamento na área de interesse, num raio de 200 metros a partir dos limites da área do empreendimento, utilizando mapas locais e informações cedidas por moradores e proprietários de estabelecimentos vizinhos à área em conformidade, com recomendações da CETESB.

A coleta de amostras para análise de metais se deu a partir da cravação do liner, por meio de um martelete hidráulico, em 16 pontos de sondagem (S-01 a S- 16), sendo coletadas amostras a cada metro perfurado, variando a profundidade de $2,50 \mathrm{~m}$ a $11,20 \mathrm{~m}$, utilizando trado mecanizado, com diâmetro de perfuração de 6 polegadas. A parcela de solo selecionada foi transferida manualmente do liner para um frasco de vidro, identificada e resfriada a $4^{\circ} \mathrm{C}$, antes de ser enviada ao laboratório. Para os resultados foram utilizados somente os pontos que apresentaram alguma concentração de metais (S-02, S-07, S-09, S-12 e S-14), nos demais não foram identificados valores acima de 0 (zero), então não foram demonstrados.

Os padrões de referência utilizados nas análises de metais foram USEPA 6010C/USEPA 1631E e as concentrações máximas aceitáveis preconizadas pela CETESB. Embora, segundo o plano diretor municipal, a área seja considerada de expansão urbana, o valor de intervenção utilizado para comparação de resultados foi o Industrial, com base na Decisão de Diretoria 045/2014-E-C-I, de 20 de fevereiro de 2014, que dispõe sobre os Valores Orientadores para Solos e Águas Subterrâneas no Estado de São Paulo.

Foram levantados Boletins de Ocorrências emitidos pela Secretaria de Estado da Segurança Pública - Polícia Civil do Estado de São Paulo, de casos de sinistros ocorridos na área atingida pelos vagões abandonados e estacionados na linha férrea e Relatórios elaborados pela Secretaria Municipal da Saúde de Iperó/SP.

\section{RESULTADOS E DISCUSSÃO}

A área de estudo, localizada na cidade de Iperó, coordenadas UTM 225,356km E / $7.415,043 \mathrm{~km} \mathrm{~N} \mathrm{(23} \mathrm{k,} \mathrm{WGS-84),} \mathrm{é} \mathrm{de}$ ocupação mista, onde encontram-se comércios juntamente com residências. A água para abastecimento utilizada no entorno é proveniente da companhia de abastecimento e não há poços de captação de água subterrânea cadastrados nas imediações da área de estudo. Porém, de acordo com a norma ABNT/NBR 13.786/2001, a área investigada pode ser classificada como Classe 3 , devido à presença de corpos naturais superficiais de água destinados à proteção de comunidades aquáticas. A área adjacente ao objeto de estudo é uma área de várzea.

Foram contabilizados 326 vagões em péssimo estado de conservação, enferrujados, desgastados e alguns com indícios de vazamento de produtos anteriormente 
transportados, como combustíveis, óleo diesel, massa asfáltica e óleo BPF. O eventual desgaste dos vagões e a exposição de materiais deixados no interior dos mesmos configura uma fonte de contaminação, uma vez que todos estavam dispostos a céu aberto.

Os resultados obtidos a partir das análises das amostras de solo indicaram que, apesar de identificadas concentrações de metais, não foi ultrapassado o valor de intervenção da CETESB para uso industrial. Na Tabela 1 estão expostos somente os pontos que apresentaram alguma concentração de metais, nos demais não foram identificados valores acima de 0 (zero).

Tabela 1. Concentrações de metais no solo.

\begin{tabular}{|c|c|c|c|c|c|c|c|c|}
\hline Parâmetros & S-02 & S-07 & S-09 & S-12 & S-14 & & $\begin{array}{l}\text { es de interver } \\
\text { Cetesb }\end{array}$ & ção - \\
\hline Metais (mg/kg) & $1 \mathrm{~m}$ & $1,5 \mathrm{~m}$ & $0,5 \mathrm{~m}$ & $4,5 \mathrm{~m}$ & $5,0 \mathrm{~m}$ & Agrícola & Residencial & Industrial \\
\hline Alumínio & 10092,6 & 15622,6 & 17807,7 & 15622,6 & 17807,7 & - & - & - \\
\hline Antimônio & ND & ND & ND & ND & ND & 5 & 10 & 25 \\
\hline Arsênio & ND & ND & ND & ND & ND & 35 & 55 & 150 \\
\hline Boro & ND & ND & ND & ND & ND & - & - & - \\
\hline Bário & 13,3 & 7,12 & 11,1 & 7,12 & 11,1 & 500 & 1300 & 7300 \\
\hline Cádmio & ND & ND & ND & ND & ND & 3,6 & 14 & 160 \\
\hline Chumbo & 4,51 & 8,79 & 7,85 & 8,79 & 7,85 & 150 & 240 & 4400 \\
\hline Cobalto & ND & ND & ND & ND & ND & 35 & 65 & 90 \\
\hline Cobre & ND & 3,65 & 4,2 & 3,65 & 4,2 & 760 & 2100 & 10000 \\
\hline Cromo & 5,96 & 218,4 & 14,5 & 218,4 & 14,5 & 150 & 300 & 400 \\
\hline Ferro & 3620 & 11280,5 & 8558 & 11280,5 & 8558 & - & - & - \\
\hline Manganês & 90,1 & 66,2 & 60,5 & 66,2 & 60,5 & - & - & - \\
\hline Mercúrio & ND & ND & ND & ND & ND & 1,2 & 0,9 & 7 \\
\hline Molibdênio & ND & ND & ND & ND & ND & 11 & 29 & 180 \\
\hline Níquel & ND & ND & ND & ND & ND & 190 & 480 & 3800 \\
\hline Prata & ND & ND & ND & ND & ND & 25 & 50 & 100 \\
\hline Selênio & ND & ND & ND & ND & ND & 24 & 81 & 640 \\
\hline Vanádio & 11,5 & 40 & 30,8 & 40 & 30,8 & - & - & - \\
\hline Zinco & 7,13 & 9,28 & 9,81 & 9,28 & 9,81 & 1900 & 7000 & 10000 \\
\hline Sódio & - & 59,9 & - & 59,9 & 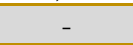 & - & - & - \\
\hline
\end{tabular}

Fonte: Geoambiente, 2014.

Segundo a CETESB (2014) os Valores de Prevenção indicam que há uma preocupação quanto a uma alteração a qualidade do solo. Já os Valores de Intervenção indicam que determinada substância no solo está acima do limite, existindo riscos em potencial. O Valor de Prevenção do Cromo(Cr) é de 75 (mg/kg), podendo observar, nos pontos S-07 e S-12, que os valores obtidos com a análise ultrapassam tal referência.

Águas subterrâneas não foram analisadas, porém seria de extrema importância que fossem realizadas análises para se ter conhecimento da situação em que as mesmas se encontram, pois as substâncias encontradas no solo podem ter percolado.

Com o levantamento dos Boletins de Ocorrência, foram obtidos dados de situações como tráfico e esconderijo de drogas, esconderijos de meliantes, homicídios, localização de cadáver, entre outros, conforme Tabela 2. 
Tabela 2. Boletins de ocorrência e ofícios.

\begin{tabular}{|c|c|c|}
\hline Data & Documento & Assunto \\
\hline 27/06/2011 & $\begin{array}{l}\text { Ofício da Polícia Militar de SP no } \\
\text { 40BPMI-236/340/11 }\end{array}$ & Registro de existência de homicídio e encontro de cadáver \\
\hline 06/07/2011 & $\begin{array}{l}\text { Ofício da Delegacia de Polícia } \\
\text { de Iperó n-340/11 }\end{array}$ & Homicídio consumado e encontro de cadáver \\
\hline 06/10/2011 & $\begin{array}{l}\text { Boletim de Ocorrência RDO } \\
868 / 2011\end{array}$ & Prisão em flagrante - tráfico de drogas \\
\hline $10 / 06 / 2013$ & $\begin{array}{l}\text { Ofício da Polícia Militar de SP no } \\
\text { 40BPMI-212/340/13 }\end{array}$ & $\begin{array}{l}\text { Tráfico e esconderijo de drogas e localização de indivíduo em } \\
07 / 06 / 13 \text { entre o vagões portanto arma de fogo }\end{array}$ \\
\hline $11 / 07 / 2013$ & $\begin{array}{l}\text { Boletim de Ocorrência RDO } \\
553 / 2013\end{array}$ & Furto qualificado de diversos materiais no prédio da Estação \\
\hline 19/07/2013 & $\begin{array}{l}\text { Ofício da Delegacia de Polícia } \\
\text { de Iperó n-492/13 }\end{array}$ & $\begin{array}{l}\text { Conteúdo: } 05 \text { B.O. de tráfico de entorpecentes, } 04 \text { B.O.de } \\
\text { furtos residenciais, } 02 \text { B.O. de furtos consumados (trilhos), } 02 \\
\text { B.O. de capturade foragidos e procurados, } 01 \\
\text { B.O. de lesão corporal culposa e } 01 \text { B.O. de ato infracional } \\
\text { art.309 e art. } 310 \text { em } 2012 \text { e } 02 \text { B.O. de tráfico } \\
\text { de entorpecentes, } 01 \text { B.O. de furto residencial, } 01 \text { B.O. de } \\
\text { ocorrência de homicídio, } 01 \text { B.O. de captura de foragidos e } \\
\text { procurados, } 01 \text { B.O. de furto qualificado, } 01 \\
\text { B.O. de localização e apreensão de drogas e } 01 \text { B.O. de } \\
\text { localização de veículo produto de roubo, utilizado em } \\
\text { assalto a banco no município em } 2013 \text {. }\end{array}$ \\
\hline 2013 & $\begin{array}{l}\text { Relatório da Guarda Civil } \\
\text { Municipal de Iperó }\end{array}$ & $\begin{array}{l}\text { BO n. } 20562 \text { - Ato infracional adolescente; BO n. } 20576 \text { - } \\
\text { Auxilio Público de Socorro; BO n.․ } 21459 \text { - Averiguação; BO } \\
\text { n. } 22237 \text { - Averiguação: uso de entorpecentes; BO n.․ } 22685 \\
\text { - Dano e depredação iluminação de via; BO n.․ } 22685 \text { - Dano } \\
\text { e depredação do Centro de Convivência da Terceira Idade } \\
\text { (CECONTI) }\end{array}$ \\
\hline
\end{tabular}

Fonte: Multiper Corrêa \& Viola, 2013.

Nos relatórios elaborados pela Secretaria Municipal da Saúde, a Vigilância Epidemiológica relata que a situação de abandono causa à população um grande risco para saúde, devido à proliferação de dengue e de animais peçonhentos tais como, aranha, escorpião, roedores e aumento de caramujos africanos. Relata também o aparecimento e aumento de algumas doenças como leptospirose, tétano, AIDS e outras Doenças Sexualmente Transmissíveis - DST's.

\section{Imagem 3 - Estação Ferroviária e Antigo Pátio de Vagões (2016)}

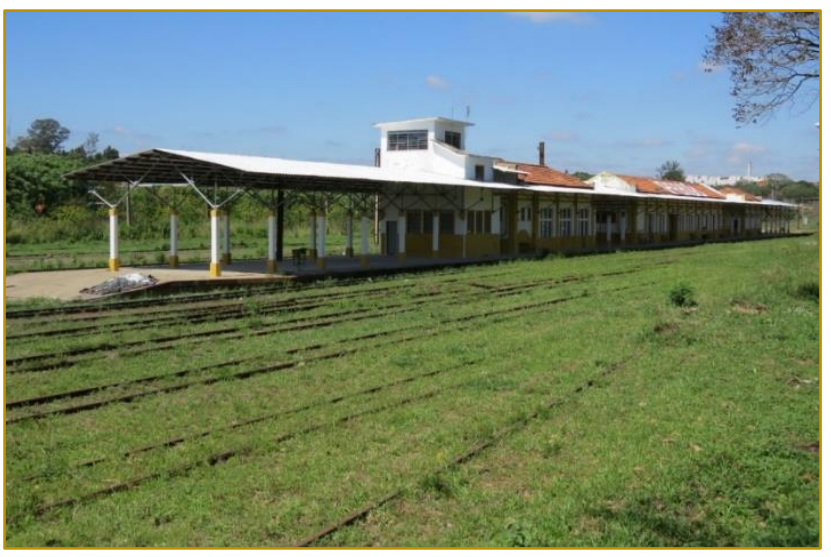

(Hugo Augusto Rodrigues)

Em âmbitos Jurídicos a prefeitura de Iperó propôs uma ação de remoção das sucatas sob pena de multa diária. Após a inercia da empresa, o Dep. Jurídico recorreu ao Tribunal de Justiça de São Paulo aplicando nova multa.

Prefeitura de Iperó também atuou através da Ação Civil Pública conforme proporcionado 
pelo Artigo 249 do Código Civil e Artigo 634 do Código de Processos Civil que possibilitaram que o "credor" (Prefeitura de Iperó) aja a favor do objetivo principal (retirada dos vagões e limpeza da área) e o "devedor" (empresa responsável pela logística dos vagões) custeie todo o valor gasto na execução do propósito inicial.
Após o caso judicial, o município de Iperó conseguiu uma liminar na justiça e pôde executar a retirada dos vagões antes encontrados no local e realizar a limpeza do terreno. Os laudos e seus resultados encontram-se em análise pela CETESB para determinar a contaminação e ação que será aplicada no local.

Imagem 4 - Início Da Retirada Dos Vagões (2013)

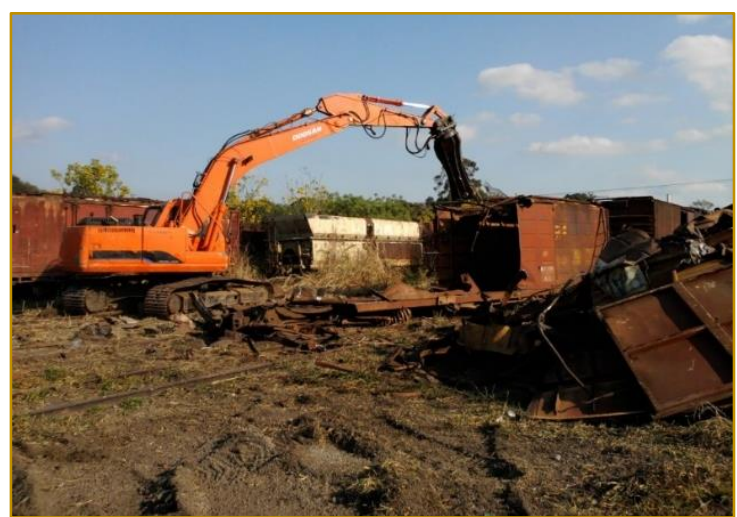

(Hugo Augusto Rodrigues)

\section{CONCLUSÕES}

É possivel concluir que o abandono dos vagões no entorno da Estação Ferroviária de Iperó/SP trouxe danos tanto para a população, vítimas de doenças e criminosos, quanto ao meio ambiente, pois embora não tenha sido comprovada.

contaminação do solo, foram encontrados metais no mesmo, onde ficou exposto durante bastante tempo e até o momento não foram aplicadas medidas mitigadoras.
Podemos notar também a suma importância do Direito Ambiental na Constituição Federal para que a qualidade de vida seja humanizada e digna para as presentes e futuras gerações. $O$ envolvimento da sociedade em questões ambientais não deve ser esquecido, pois é cumprimento da legislação onde é cobrado atitudes do Ministério Público.

Imagem 5 - Atualmente onde ficavam alocados os vagões abandonados existe o Centro Nacional de Balonismo de Iperó (2017)

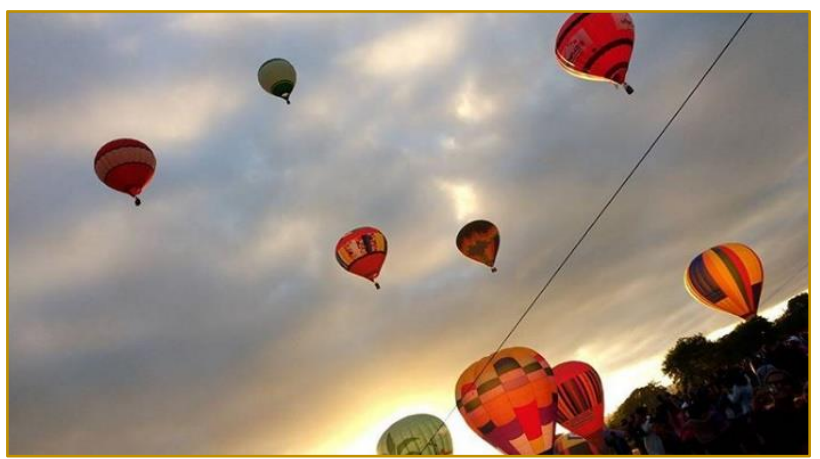

(Stephanie Fidalgo) 


\section{AGRADECIMENTOS}

Agradecemos à Universidade de Sorocaba e à nossa orientadora Profẹ $\stackrel{a}{\text {. Dr }}$. Débora Zumkeller Sabonaro, por nos orientar e nos acompanhar desde o começo. Ao Dr. Solano de Camargo por nos inspirar a lutar pelos nossos ideais com a história verídica contada

\section{REFERÊNCIAS}

[1] Arcaro, N. P. Laudo Técnico de Avaliação Preliminar no Âmbito da Área da Prefeitura Municipal de Iperó/SP. Piracicaba: Grupo Sondamar, 2013. 34 p.

[2] Camargo, S. A Guerra dos Vagões: A luta de uma comunidade pelo fim do cemitério de vagões. Editora Casa do Novo Autor, 2015. 220p.

[3] Canatelli,S.Ahistóriadelperó.Online.Disponí vel em:<http://www.ipero.sp.gov.br/nossa-historia/> Acesso em: 05 nov. 2015.

[4] Cetesb. Valores orientadores para solo e água subterrânea no Estado de São Paulo, 2014. Online.Disponívelem:<http://solo.cetesb.sp.gov.br/ wp- content/uploads/sites/34/2014/12/valoresorientadores-nov-2014.pdf $>$. Acesso em: 10 mar. 2016. em seu livro "A Guerra dos Vagões", ao Sr. Hugo Augusto Rodrigues, Sr. Sandro Canatelli, Sr. Lino Leandro de Barros, à Prefeitura Municipal de Iperó e CETESB Sorocaba por todo apoio que nos foi dado.

[5] Corrêa, R. C. Laudo Técnico - Estação de Trens Prefeitura Municipal de Iperó. Vinhedo: Multiper Corrêa e Viola, 2013. 33p.

[6] Ibge - Instituto Brasileiro de Geografia e Estatística. São Paulo >> Iperó. Online. Disponível em:<http://www.cidades.ibge.gov.br/xtras/perfil.ph p?lang=\&codmun=352100\&search=llinfogr\%E 1ficos:-informa\%E7\%F5es-completas> Acesso em: 10 nov. 2015.

[7] Masset, R. B. G. Relatório de Monitoramento Ambiental da Qualidade do Solo. São José do Rio Preto, Geoambiente, 2014. 261 p.

[8] Rodrigues, H. A. Iperó - História do município remonta a mais de 500 anos. Online. Disponível

em: <http://www.cidadedeipero.com.br/ipero.html> Acesso em: 07 nov. 2015. 


\section{Bapítulo 2}

\section{IDENTIFICACÃO DOS IMPACTOS AMBIENTAIS ASSOCIADOS À COBERTURA E USO DA TERRA NO MUNICÍPIO DE BROTAS DE MACAÚBAS (BA)}

Niédja Sodré de Araújo

Dária Maria Cardoso Nascimento

Resumo - O município de Brotas de Macaúbas está localizado no Estado da Bahia e possui $2.367,56 \mathrm{~km}^{2}$. Esta pesquisa teve por objetivo analisar a cobertura e uso da terra do município e os principais impactos ambientais associados. Utilizou-se imagem orbital Landsat8, realizaram-se composição e fusão de bandas espectrais, segmentação e classificação não supervisionada. Destacaram-se a cobertura vegetal $(64,02 \%)$ e os tipos Pastagens (15,80\%) e Cultura Temporária (15,18\%). As áreas Urbanizadas, e Áreas Descobertas totalizaram apenas 5,0\%. Adicionaram-se polígonos georreferenciados de explotação mineral (DNPM, 2014) com Áreas de concessão de lavra e simbologia pontual para mina e parque eólico. Os principais impactos negativos verificados em campo: modificação da paisagem e produção de ruídos pela mineração; condições insalubres em minas subterrâneas; e, poluição visual e do ar pelo descarte e queima de resíduos sólidos em lixão a céu aberto. Dentre os impactos positivos destacam-se a melhoria dos acessos rodoviários em localidades próximas ao complexo eólico e acesso aos serviços de documentação para comunidades impactadas pelo mesmo complexo, e dentre outros, geração de renda para pequenos trabalhadores rurais na agricultura familiar ou em atividade de garimpo nos período de estiagem.

Palavras-chave: Geotecnologias, Mapeamento, Ambiente. 


\section{INTRODUÇÃO}

O município de Brotas de Macaúbas localizase no Estado da Bahia, na região semiárida do Nordeste e na Chapada Diamantina, a 600 $\mathrm{km}$ da capital. Possui 2.367,56 km², 10.717 habitantes e destes 7.599 residem em área rural, portanto, o município é predominantemente agrário. A descoberta de diamante e ouro foi a principal razão para o povoamento do lugar, desenvolvendo-se, posteriormente a agricultura, pecuária e tornou-se independente em 16 de julho de1878. Segundo o IBGE, o levantamento sobre Cobertura e o Uso da Terra comporta análises e mapeamentos muito úteis para 0 conhecimento atual das formas de uso e de ocupação do espaço geográfico (IBGE, 2013). Com o melhoramento das técnicas de geotecnologias a geografia passou a contar com a possibilidade de desenvolver documentos cartográficos mais precisos para produção de conhecimento sobre os fenômenos geoespaciais com diferentes níveis de detalhamento.

As geotecnologias podem ser entendidas como as novas tecnologias, ligadas e correlatas às geociências e sistemas de referência, para auxiliar no desenvolvimento de pesquisas, planejamento, gestão, manejo dentre outros aspectos relacionados à estrutura do espaço geográfico (FITZ, 2008). Neste contexto, o impacto ambiental significa a alteração da qualidade ambiental, benéfica ou adversa e resulta da modificação de processos naturais ou sociais, provocada por ação humana. Assim o conceito de ambiente pode incluir natureza, sociedade e faz referência ao meio de onde a humanidade extrai os recursos essenciais à sua sobrevivência (SÁNCHEZ, 2008). Esta pesquisa teve como objetivo geral mapear a cobertura e os tipos de uso da terra no município de Brotas de Macaúbas (BA) e os objetivos específicos foram: i) Classificar a cobertura e os principais tipos de uso da terra no Nível II; ii) Relacionar os principais impactos ambientais identificados em campo aos tipos de uso; iii) Espacializar áreas de explotação mineral.

\section{MATERIAL E MÉTODOS}

Realizou-se download de uma imagem orbital do satélite Landsat 8, com resolução espacial de $30 \mathrm{~m}$, órbita 218 , ponto 68 , de agosto de 2014, no banco de dados do Serviço Geológico dos Estados Unidos (USGS, 2014).
Em seguida, no Spring - um Sistema de Informações Geográficas (SIG), combinaramse as bandas 6, 5 e 4 na ordem RGB, realizaram-se reamostragem e fusão com a banda pancromática, por meio do software Spectral Transformer for Landsat para assumir resolução espacial de $15 \mathrm{~m}$. Atualizou-se a base cartográfica (edição de estradas e localidade) no ArcGis utilizando como referência as folhas topográficas SC-23-X-IV, SC-23-X-II, SD-23-F-I e SD-23-F-II, escala 1: 100.000, e limite municipal atualizado de 2013 pela Superintendência de Estudos Econômicos e Sociais da Bahia (SEI). No Spring realizou-se segmentação e classificação não supervisionada para mapeamento de cobertura e uso da terra na escala de 1: 250.000. Foram geradas 19 classes e em seguida estas foram exportadas para o formato vetorial (em polígono) shapefile e manipuladas no ArcGis onde foram generalizadas em 6 classes com área mínima de $1,56 \mathrm{~km}^{2}$, em Nível II de detalhamento, adaptado do manual técnico de cobertura e uso da terra do IBGE (2013). As Áreas de Concessão de Lavra integram o mapa e correspondem aos polígonos georreferenciados de processos minerários do Departamento Nacional de Produção Mineral (DNPM, 2014) totalizando 7 classes: i) Áreas Urbanizadas; ii) Áreas de Concessão de Lavra, iii) Culturas Temporárias, iv) Pastagens (associadas a Culturas Temporárias); v) Área Campestre I (predomínio de Savana-Estépica) e vi) Área Campestre II (contato entre Savana Arborizada e Savana-Estépica); e, vii) Áreas Descobertas. Por fim, foram realizados trabalhos de campo em 2014 e 2015, utilizando-se Global Positioning System (GPS) de navegação para coleta de pontos de interesse e obteve-se apoio da Prefeitura Municipal de Brotas de Macaúbas para deslocamento no município e validação do mapa. Realizou-se entrevista semi-estruturada com trabalhadores vinculados às atividades de mineração durante trabalho de campo.

\section{RESULTADOS E DISCUSSÃO}

As Áreas Urbanizadas compreendem apenas a cidade de Brotas de Macaúbas, embora o complexo industrial eólico e algumas localidades também pertençam a essa classe, as extensões correspondentes $\mathrm{em} \mathrm{km}^{2}$ na imagem orbital são inferiores à área mínima de mapeamento, portanto, foram representadas por símbolos do tipo ponto. As 
Áreas de Concessão de Lavra correspondem às áreas autorizados para explotar recursos minerais. Dentro dessas áreas foi possível localizar algumas minas onde foram representadas por símbolos pontuais. As Culturas Temporárias estão associadas aos mosaicos de usos que envolvem a utilização de mais de três produtos, geralmente conjugam culturas temporárias, avicultura e suinocultura, como ocorre na agricultura familiar e de subsistência (IBGE, 2013). As pastagens correspondem às áreas destinadas a pecuária extensiva associadas às culturas temporárias. Na Área Campestre I predomina Savana-Estépica e na Área Campestre II há contato entre Savana Arborizada e Savana-
Estépica, prevalecendo estrato arbustivo, esparsamente distribuído sobre terreno com cobertura vegetal lenhosa em diferentes tipologias. As Áreas Descobertas referem-se aos ambientes naturais ou antrópicos, por exemplo, rochas desnudas, áreas abandonadas de extração mineral ou sem cobertura vegetal ou outras categorias não classificadas no manual técnico de cobertura e uso da terra, correspondendo neste trabalho aos terrenos com concentração de murundus, ou seja, montículos sobre o terreno. A Figura 1, Cobertura e Uso da Terra do Município de Brotas de Macaúbas - Bahia, 2015, corresponde ao mapeamento realizado.

Figura 1 - Cobertura e Uso da Terra do Município de Brotas de Macaúbas - Bahia, 2015.

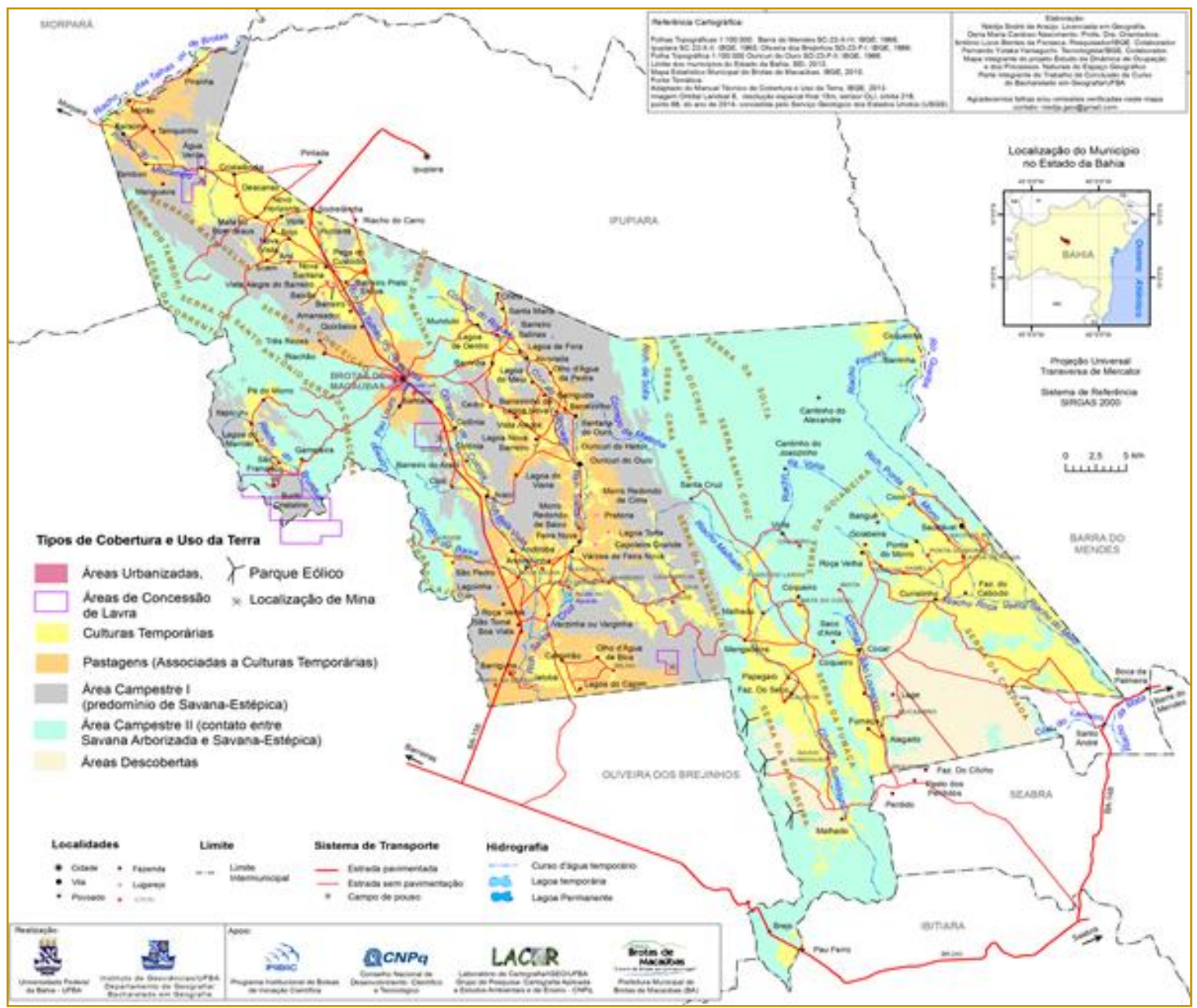

Fonte: As autoras, 2015.

Áreas Urbanizadas: corresponde à sede municipal com 3,25 $\mathrm{km}^{2}$ da área total $(0,14 \%)$ e ao parque eólico representado no mapa por símbolo pontual. alguns impactos positivos: melhoria da renda local pelo repasse de royalties aos proprietários de terra arrendada, alargamento de estradas, acesso à energia elétrica, aquisição de carteiras de trabalho e de identidade pela população local, contudo, ocorreram conflitos envolvendo posse de terra 
no processo de implantação. impactos negativos: poluição do ar pelo descarte e queima de resíduos sólidos em lixão; comprometimento das águas fluviais no período chuvoso pelo lançamento de efluentes da área urbana "in natura" no riacho de brotas.

\begin{abstract}
Áreas de concessão de lavra
As minas subterrâneas (garimpo de quartzo) e as superficiais a céu aberto (extração de conglomerados e quartzito), figura 2, foram representadas no mapa por polígonos georreferenciados registrados no dnpm que referem-se às áreas de concessão de lavra, no total $30 \mathrm{~km}^{2}$.
\end{abstract}

Figura 2 - Minas a céu aberto e minas subterrâneas com garimpeiros sobre pilhas de rejeito, município de Brotas de Macaúbas (BA).

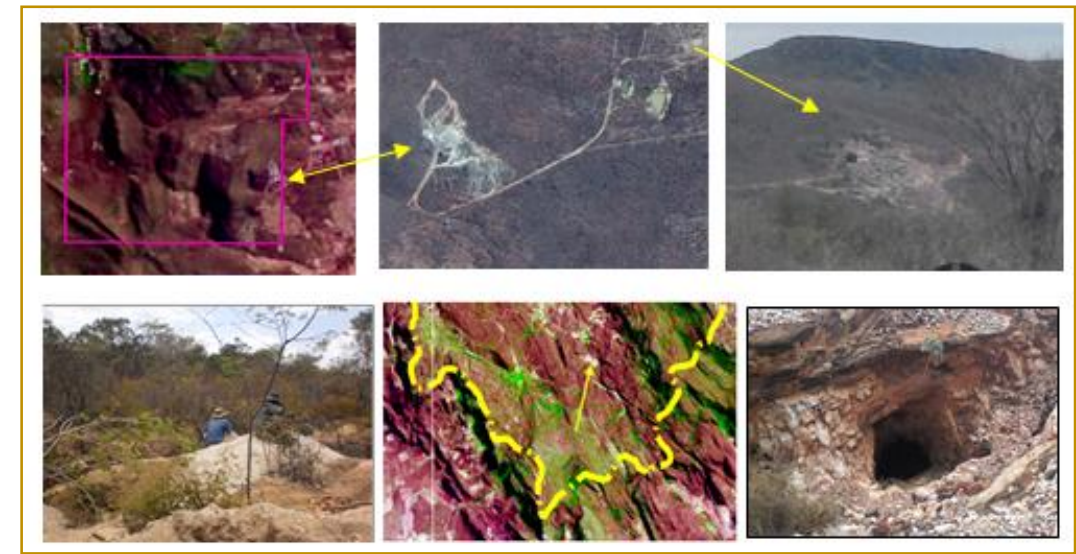

Fonte: Trabalho de Campo, 2015; USGS, landsat8, 2014; Google, 2015.

As coordenadas geodésicas de algumas minas foram coletadas em campo e na imagem orbital verificaram-se manchas brancas que correspondem à resposta espectral de pilhas de rejeito (solos revolvidos e lascas de cristais) de minas subterrâneas ou de solo exposto resultante das minas superficiais a céu aberto, representadas cartograficamente por símbolos pontuais (Localização de Mina). As atividades em minas subterrâneas podem causar os seguintes impactos na saúde e segurança dos garimpeiros a: i) inalação de poeira e componentes da rocha dispersos no ar; ii) desconforto térmico com altas temperaturas conforme aumento de profundidade no subsolo, iii) pouca disponibilidade de oxigênio e iluminação, iv) riscos de desabamento de terra ou rolamento de bloco de rochas sobre eles, durante as escavações v) risco de acidentes durante manipulação de explosivos ou associados à falta de uso de Equipamento de Proteção Individual (EPI) para segurança, entretanto, esta atividade causa pouco impacto visual e atrai trabalhadores rurais nativos durante as estações secas na região (outono/inverno) e estes carecem de apoio financeiro para modernização do garimpo e ampliação da economia municipal neste setor. O outro tipo de mineração a céu aberto mais industrializada, requer mão-de-obra qualificada para operar os equipamentos e emprega poucos nativos. Tais atividades consomem água potável na extração mineral, recurso natural escasso no ambiente de estudo. Assim, a mineração na superfície do solo causa maior poluição visual comparada à subterrânea, pois, remove consideravelmente a cobertura vegetal para a retirada de blocos de rochas e oferece baixo retorno econômico para o município, visto que o refinamento das rochas para comercialização é realizado por empresas de outros estados, a citar, Minas Gerais e Espírito Santo, conforme verificado com trabalhadores em campo. Vale ressaltar também que a declaração da quantidade bruta explotada é realizada pela própria empresa de mineração. Outro tipo de mineração identificada em campo confere à extração de areia, que não foi mapeada nesta pesquisa, mas merece ser fiscalizada. No DNPM não consta declaração das atividades de mineração de areia, assim há ausência de arrecadação tributária sobre este tipo de 
recurso, além de impactos ambientais na paisagem e ausência de recuperação de áreas degradadas.

Culturas Temporárias: Este tipo de uso corresponde aos cultivos com ciclo vegetativo inferior a um ano $e$ às lavouras semipermanentes como cana-de-açúcar, mandioca, algumas forrageiras, também pertencem à categoria de culturas temporárias (IBGE, 2013). No município destacam principalmente o cultivo de mandioca, milho, feijão e cana-de-açúcar (IBGE, 2014a) e estão concentradas nos arredores dos povoados, principalmente em áreas pediplanadas e às margens de cursos d'água, contabilizando $359,42 \quad \mathrm{~km}^{2}$, equivalente a $15,18 \%$ da área.

As culturas temporárias localizam-se nas áreas de pediplano onde os solos são mais desenvolvidos, predominando os Latossolos. Entre os impactos negativos causados por este uso: queimada e desmatamento das savanas para a agricultura e remoção da vegetação ciliar das margens dos cursos d'água temporários. Entretanto, este uso corresponde a uma forma de subsistência no contexto da agricultura familiar durante a primavera e o verão quando ocorre concentração de chuva na região.

Pastagens (associadas a Culturas Temporárias):As pastagens não são naturais da área, ocorrem principalmente nas margens de trechos da BA-156 e em locais pediplanados, ocupam $374,10 \mathrm{~km}^{2}$ (15,80\%). Algumas áreas com plantações de feijão, milho, dentre outros, são utilizadas para pastagem no período de estiagem. Há ocorrência de criação de bovinos livres de cercados, em áreas de fundo e fecho de pasto associada à caatinga. Assim, ocorre remoção da cobertura vegetal natural para inserção de pasto e compactação do solo por pisoteamento.

Área Campestre I (Predomínio De SavanaEstépica) E Área Campestre li (Contato Entre Savana Arborizada E Savana-Estépica): $\mathrm{Na}$ Área Campestre I predomina SavanaEstépica, também denominada de caatinga, com espécies xerófilas, lenhosas, adaptadas ao clima semiárido do Nordeste, morfologia de porte pequeno e cespitoso, ou seja, ramificações de troncos sustentados por uma mesma raiz. Totalizam $464,56 \mathrm{~km}^{2}$ ou $19,62 \%$, com ocorrência em solos pedregosos e rasos. Nos topos de serras há o contato entre Savana-Estépica e Savana Arborizada por ser uma área de transição, de maior altitude e umidade, juntas totalizam 64,02\%. Na área Campestre II com 1.051,13 km² predomina a Savana Arborizada ou Cerrado, localizada em superfícies pediplanadas, relevos montanhosos e dissecados inseridos no Grupo Chapada Diamantina, com espécies lenhosas, baixas e tortuosas, entre 2 a $4 \mathrm{~m}$ (BRASIL, 1982, p. 468-492). Nas áreas campestres I e II ocorre extração de lenha, porém, destacam-se: a produção de umbu, coquinho licuri, mangaba e castanha de caju (IBGE, 2014b), que são fonte de renda para pequenos produtores rurais. As savanas são impactadas negativamente principalmente pelas atividades agropecuárias e mineração.

Áreas Descobertas:As Áreas Descobertas fazem referência às superfícies continentais terrestres com cobertura vegetal rarefeita com presença de murundus (Figura 03), ou seja, montículos sobre o terreno, associados à atividade biológica ou erosão diferenciada.

Figura 03 - Vista horizontal e vertical de áreas com murundus, município de Brotas de Macaúbas (BA).



Fonte: Trabalho de Campo, 2014; USGS, Landsat8, 2014. 
Para alguns autores murundu corresponde a um tipo de micro-relevo associado às condições de má drenagem e são formações de origem natural com configuração aproximadamente cônica, em geral da ordem de 3 a 22 m de diâmetro, à base, e a altura raramente excede 3 metros" (RESEND et al. 2002; OLIVEIRA FILHO 1998 apud ANTUNES et al. 2012). Representam 115,1 km² (4,86\%), concentrados na porção sul do oeste, embora também ocorra em outras áreas e geralmente estão associadas à criação de animais de médio e grande porte como suínos, caprinos, bovinos.

\section{CONCLUSÕES}

Dentre os tipos de uso e cobertura da terra destacou-se a cobertura vegetal com 64,02\% da área total do município de Brotas de Macaúbas, seguido do tipo Pastagens (associadas às Culturas Temporárias) com 15,80\%, posteriormente, Cultura Temporária $15,18 \%$, Áreas Urbanizadas e Áreas Descobertas que representam juntas $5 \%$ e as Áreas de Concessão de Lavras sobre a cobertura vegetal correspondem a $30 \mathrm{~km}^{2}$. Dentre os impactos ambientais identificados em trabalho de campo, sobressaem: as condições insalubres e periculosas de garimpeiros em minas subterrâneas que comprometem a saúde dos mesmos; a modificação da paisagem e produção de ruídos ocasionados pela mineração; e a poluição visual e do ar pelo descarte e queima de resíduos sólidos a céu aberto. Entre os impactos positivos: melhoria da

\section{REFERÊNCIAS}

[1] Antunes, P. D. (et al.). Caracterização físico-química de micro-relevo de montículos "murundus" na região de Janaúba no norte de Minas Gerais. Revista de Geociência Geonomos. Minas Gerais: v.20, n.1, maio 2012, p. 81-85.

[2] Araújo, N. S. Estudo Ambiental do Município de Brotas de Macaúbas (BA) Face à Cobertura e Uso da Terra. Universidade Federal da Bahia (Monografia - Conclusão de Curso), Instituto de Geociências, Salvador, 2015.

[3] Brasil. Ministério das Minas e Energia. Secretaria Geral. PROJETO RADAM BRASIL. Folha SD 23 Brasília: geologia, geomorfologia, pedologia, vegetação e uso potencial da terra. Rio de Janeiro, 1982, p. 468-492. renda local pela geração de royalties com instalação do Parque Eólico, melhoria de estradas e acesso à energia elétrica em localidades próximas ao parque. Os resultados desta pesquisa poderão auxiliar o município subsidiando a gestão municipal.

\section{AGRADECIMENTO}

As autoras deste trabalho agradecem à Universidade Federal da Bahia (UFBA) em parceria com o Programa Institucional de Bolsas de Iniciação Científica (PIBIC) por apoiarem a realização desta pesquisa, bem como aos colegas do Laboratório de Cartografia da UFBA (LACAR) e ao pesquisador Fernando Yamaguchi do IBGE/BA por terem contribuído no desenvolvimento do estudo. Agrademos também à Secretaria de Meio Ambiente de Brotas de Macaúbas por ter apoiado os trabalhos de campo realizados em 2015 e agradecemos as participações voluntárias do amigo Olderico Barreto e familiares da primeira autora - Maurício Sodré e Libânio Sodré (in memoria) nas visitas aos garimpos realizadas na presença dessa autora. Este artigo foi apresentado no XIII Congresso Nacional de Meio Ambiente em Poços de Caldas (MG) com poucas alterações, correspondendo ao trabalho final do curso de Especialização em Geotecnologias (Instituto de Qualificação Profissional/EEEMBA) e integra o Trabalho de Conclusão de Curso do Bacharelado em Geografia (UFBA), ambos da primeira autora.

[4] Dnpm. Sistema de Informações Geográficas da Mineração: Processos Minerários, $2014 . \quad$ Disponível em: http://sigmine.dnpm.gov.br/webmap/. Acesso em: 28 nov. 2014

[5] Fitz, P. R. Geoprocessamento sem complicação. São Paulo: Oficina de Textos, 2008, $160 p$

[6] Ibge. Manual Técnico de Cobertura e Uso da Terra. Rio de Janeiro, 2013, n7, Ed 3르, 155 p.

[7]_...Produção.agrícola.do.município.de Brotas.de.Macaúbas,.2014a. Disponível em:

[8] .http://www.cidades.ibge.gov.br/xtras/tema s.php?lang $=\&$ codmun $=290450 \&$ idtema $=149 \&$ searc $\mathrm{h}=$ bahialbrotas-de-macaubaslproducao-agricolamunicipal-lavoura-temporaria-2014. Acesso em: 15 ago. de 2015 
[9] _...Produção de extração vegetal do município de Brotas de Macaúbas,.2014b.. Disponível.em:.http://www.cidades.ibge.gov.br/xtra s/temas. php?lang=\&codmun=290450\&idtema $=150$ \&search=bahialbrotas-de-macaubaslextracaovegetal-e-silvicultura-2014. Acesso em: 15 ago. de 2015.
[10] Sánchez, L. E. Avaliação de impacto ambiental: conceitos e métodos. São Paulo: Oficina de Textos, 2008, p. 17-42.

[11] Usgs. Imagem de Satélite Landsat 8. Disponível em: http://earthexplorer.usgs.gov/. Acesso em 10 set. 201 


\section{Bapítulo 3}

\section{EVOLUCÃO TEMPORAL DO USO E OCUPAÇÃO DO SOLO NO MUNICÍPIO DE ITAMARAJU - BA ENTRE 1990 E 2013}

\section{Giovanna França Bispo da Gama}

Gabriela Mateus de Fontes Silva

Thiara Helena Mota Almeida

João Batista Lopes da Silva

Resumo: Objetivou-se por meio desse estudo, analisar a evolução temporal do uso e ocupação do solo em toda extensão territorial do município de Itamaraju, localizado no Extremo Sul da Bahia, nos anos de 1990, 1994, 2002, 2006 e 2013. Para montagem dos mapas, utilizou-se o programa QGIS versão 2.18.9. Foram utilizadas classes de uso do solo, como: Agricultura; Comunidade Aluvial Arbórea; Eucalipto; Floresta Estágio Inicial; Floresta Estágio Médio/Avançado; Pasto Limpo; Pasto Sujo. Identificou-se que a pastagem é a matriz da paisagem, com maior conversão nesta classe entre 2006 e 2013. 


\section{INTRODUÇÃO}

Segundo dados do Instituto Brasileiro de Geografia e Estatísticas - IBGE, em 2017 a população do município foi estimada em 67.356 habitantes, e sua área territorial equivalente a $2.360 \mathrm{~km}^{2}$, dos quais, de acordo com o censo agropecuário, em 2006 possuía $2.175 \mathrm{~km}^{2}$ (cerca de 92\%) ocupada por estabelecimentos agropecuários.

Entende-se por uso do solo a forma pela qual o espaço é ocupado. As mudanças de uso e ocupação do solo ocorrem devido às atividades humanas, e incluem aspectos socioambientais, políticos e econômicos. Portanto, conhecer este aspecto é de grande importância, na medida em que os efeitos do uso desordenado causam impactos negativos (LATUF et al., 2007).

A partir de uma iniciativa do Diálogo Florestal no Brasil, foram criados os Fóruns Florestais Regionais, dentre eles, o Fórum Florestal do Sul e Extremo Sul da Bahia, que buscou gerar informações detalhadas sobre a dinâmica temporal da cobertura florestal na região a partir do projeto "Monitoramento Independente da Cobertura Florestal das Bacias Setentrionais do Extremo Sul da Bahia", no qual foram utilizados dados de sensoriamento remoto e ferramentas de geoprocessamento para identificar e mapear as mudanças do uso e cobertura do solo entre 1990 e 2013 (RIBEIRO et al., 2015).

Caracterizar a evolução temporal do uso e ocupação do solo em um município, região ou bacia hidrográfica permite diversas análises dos aspectos ambientais, sociais e econômicos envolvidos, sendo uma etapa fundamental para diagnóstico e gestão dos recursos naturais. Nesse sentido, os Sistemas de Informação Geográfica (SIG) e as inúmeras ferramentas de geoprocessamento, permitem análise quantitativa das áreas convertidas para os diversos fins. Diante da carência de estudos regionais publicados sobre essa temática, objetivou-se por meio desse trabalho, analisar a evolução temporal do uso e ocupação do solo na extensão territorial do município de Itamaraju-BA entre os anos de 1990 e 2013.

\section{METODOLOGIA}

A cidade de Itamaraju está localizada na região do Extremo Sul Baiano sob as coordenadas: latitude $17^{\circ} 02^{\prime} 2^{\prime \prime} \mathrm{S}$ e longitude $39^{\circ} 31^{\prime} 51^{\prime \prime} \mathrm{O}$, com área total de $2.368 \mathrm{~km}^{2}$ (Figura 1).

Figura 1 - Localização do município de Itamaraju - BA.

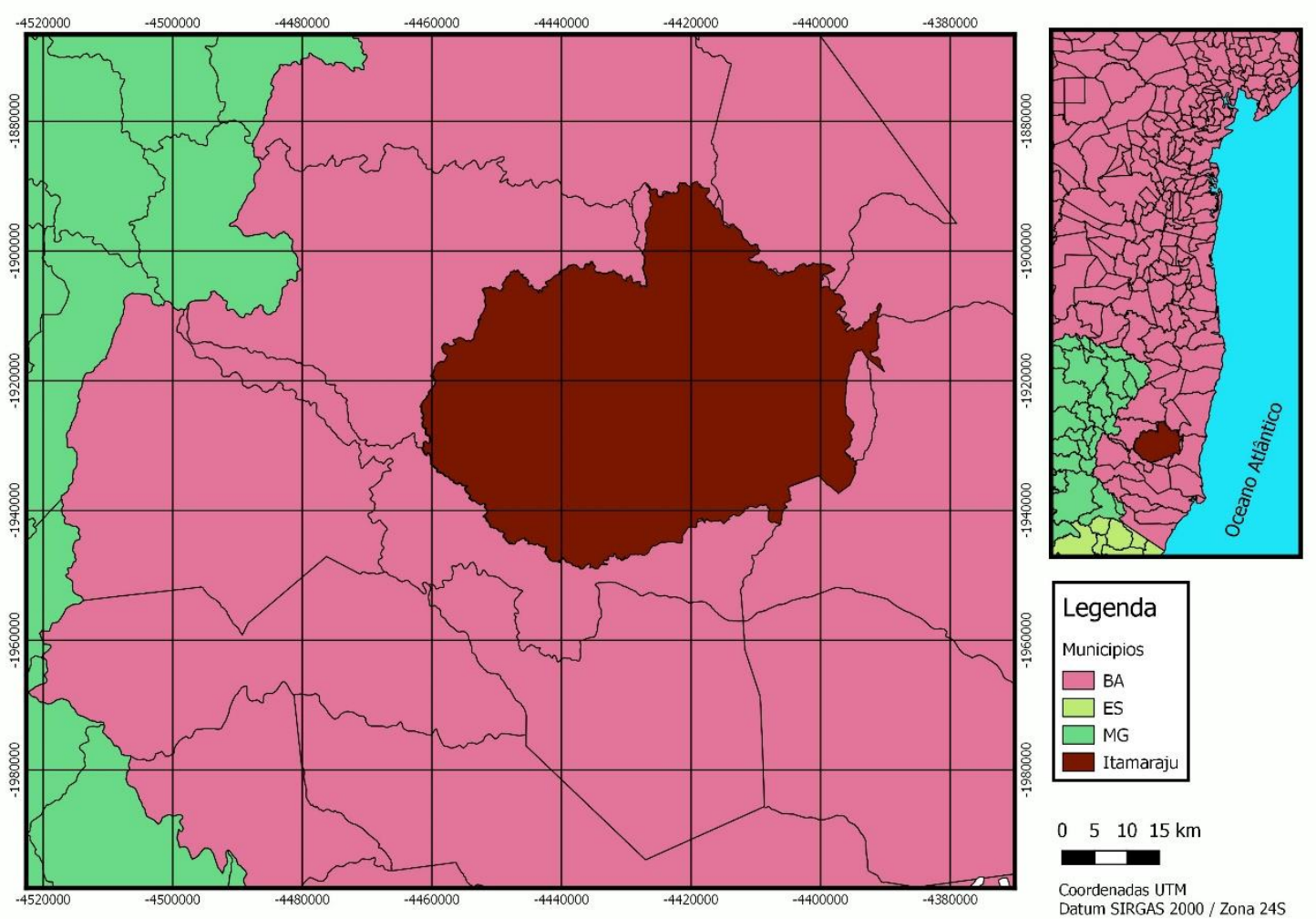


Os dados utilizados neste trabalho (tamanho da área, extensão e delimitação das classes de uso do solo) foram cedidos pelo Fórum Florestal do Extremo Sul da Bahia, utilizados para análise espaço-temporal para confecção de mapas e tabulação de dados considerando quatro intervalos de anos: 1990; 1994; 2002; 2006; 2013. Os dados provieram do processamento dos satélites Landsat 5 sensor TM (Thematic Mapper) e exclusivamente no ano de 2013 as imagens foram registradas pelo satélite RapidEye, que apresenta uma maior definição.

Para montagem dos mapas, utilizou-se o programa QGIS versão 2.18.9. Foram utilizadas as seguintes classes de uso do solo: Afloramento rochoso, Agricultura, Área úmida/várzea, Área urbana, Campos de restinga, Comunidade Aluvial Árborea, Eucalipto, Floresta estágio inicial, Floresta estágio médio/avançado, Instalações rurais, Pasto limpo, Pasto sujo, Seringal, Sistema viário (principais) e Solo exposto.

\section{RESULTADOS E DISCUSSÃO}

Não foram identificados Campo Rupestres, Mussunungas e Manguezais. Quando se considera todo o período estudado, ou seja, de 1990 até 2013, algumas classes apresentaram variação pouco expressiva como é o caso da área urbana $(0,13 \%)$, Eucalipto (0,46\%), Instalações Rurais (0,16\%), Lagos, lagoas, represas $(-0,07 \%)$ Sistema Viário $(-0,08 \%)$ e Solo Exposto $(0,02 \%)$, assim como as classes Afloramento Rochoso, Agricultura e Área Úmida/Varzea, que apresentaram conversão de aproximadamente um por cento. Em alguns casos, como a agricultura, houve um aumento considerável em um determinado período ( $5 \%$ entre 1994 e 2002), com uma redução nos períodos subsequentes ou vice-versa. Neste caso específico, observa-se que houveram mudanças na produção agrícola (Cana-deaçúcar, café e citros) que em sua maioria foi transformada em pastagem após 2002 (Figura 2 e Tabela 1).

Figura 2 - Uso e ocupação no território de Itamaraju, Bahia (1990, 1994, 2002, 2006 e 2013).
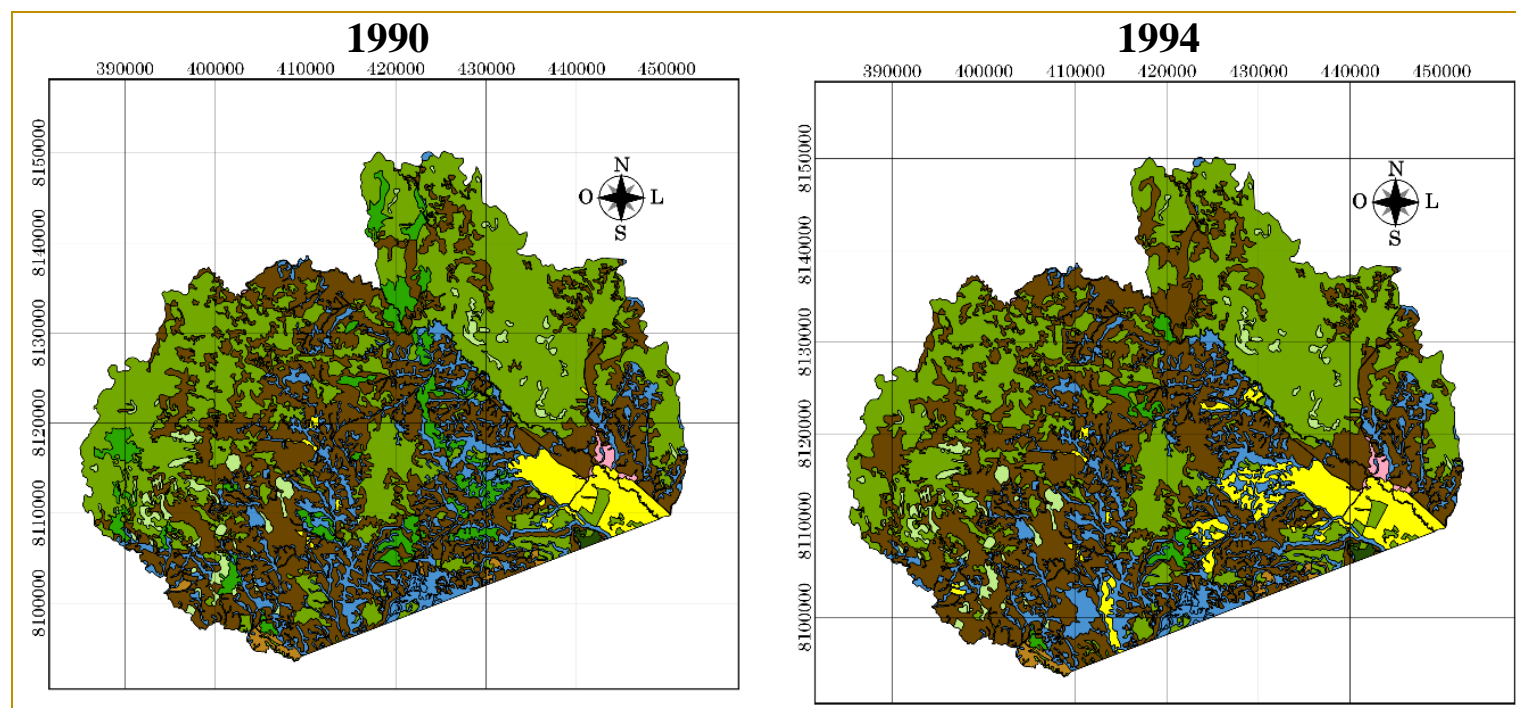
Figura 2 - Uso e ocupação no território de Itamaraju, Bahia (1990, 1994, 2002, 2006 e 2013) (continuação)

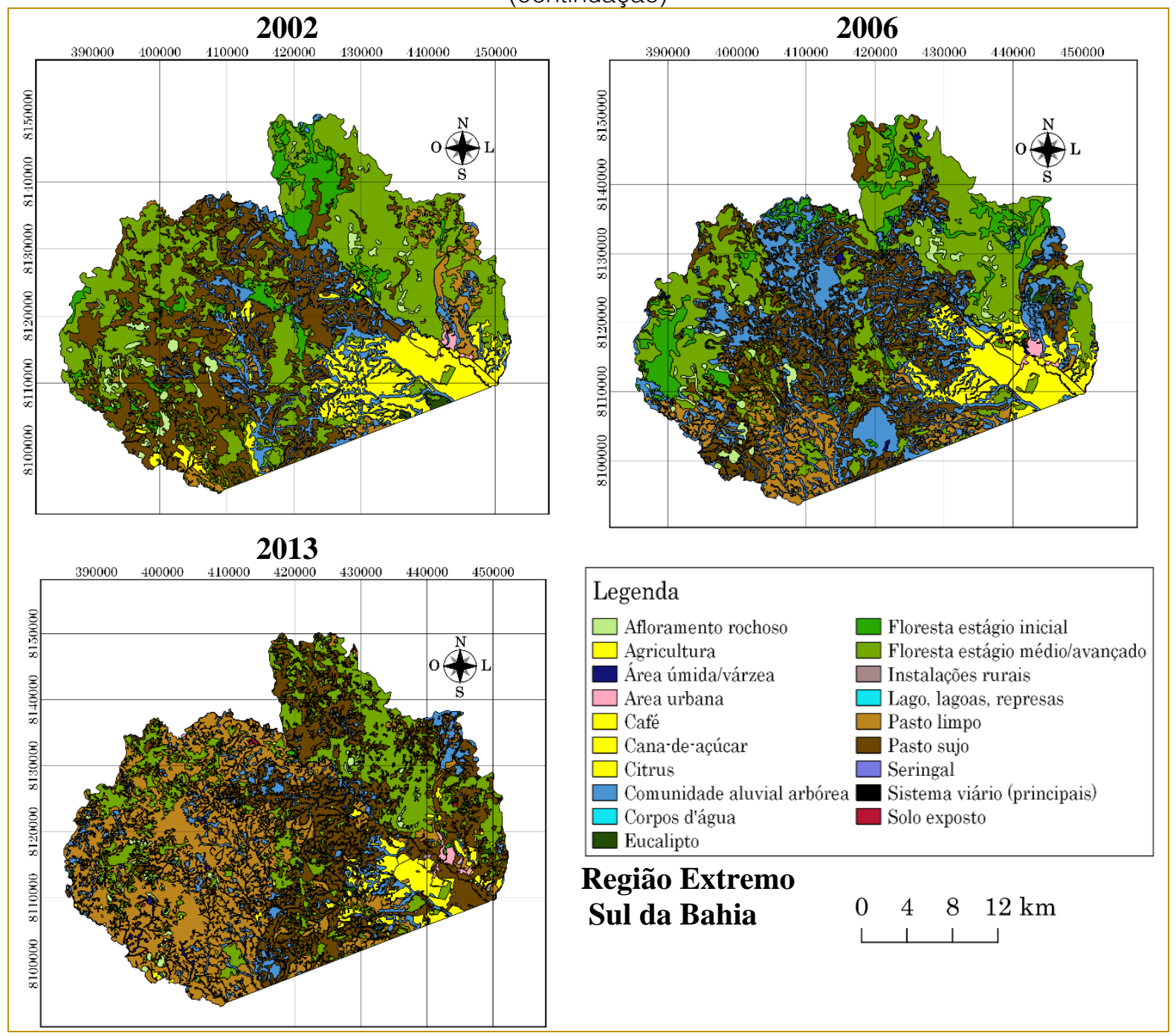

Tabela 1 - Evolução temporal do uso e ocupação do solo no município de Itamaraju - BA, nos anos de 1990, 1994, 2002, 2006 e 2013 em km² e \%

\begin{tabular}{|c|c|c|c|c|c|c|c|c|c|c|}
\hline \multirow{2}{*}{ Classe } & \multirow{2}{*}{\multicolumn{2}{|c|}{1990}} & \multicolumn{2}{|c|}{1994} & \multicolumn{2}{|c|}{2002} & \multicolumn{2}{|c|}{2006} & \multicolumn{2}{|c|}{2013} \\
\hline & & & $\mathrm{km}^{2}$ & $\%$ & $\mathrm{~km}^{2}$ & $\%$ & & $\%$ & & \\
\hline Afloramento Rochoso & 56,7 & 2,4 & 56,6 & 2,4 & 55,9 & 2,4 & 47,7 & 2,0 & 30,9 & 1,3 \\
\hline Agricultura & 72,0 & 3,0 & 114,5 & 4,8 & 236,6 & 10,0 & 169,4 & 7,2 & 100,7 & 4,3 \\
\hline Área Úmida/Narzea & 0,0 & 0,0 & 0,0 & 0,0 & 0,0 & 0,0 & 6,5 & 0,3 & 27,3 & 1,2 \\
\hline Área Urbana & 7,4 & 0,3 & 7,4 & 0,3 & 7,5 & 0,3 & 8,5 & 0,4 & 10,5 & 0,4 \\
\hline Campo Rupreste & 0,0 & 0,0 & 0,0 & 0,0 & 0,0 & 0,0 & 0,0 & 0,0 & 0,0 & 0,0 \\
\hline Campos de Restin & 0,0 & 0,0 & 0,0 & 0,0 & 0,0 & 0,0 & 0,0 & 0,0 & 0,0 & 0,0 \\
\hline Comunidade Alu & 324,5 & 13,7 & 323,6 & 13,7 & 258,5 & 10,9 & 571,0 & 24,1 & 280,8 & 11,9 \\
\hline Eucalipto & 3,5 & 0,1 & 3,5 & 0,1 & 6,1 & 0,3 & 5,9 & 0,2 & 14,3 & 0,6 \\
\hline Floresta Est. Inicial & 119,2 & 5,0 & 23,3 & 1,0 & 141,6 & 6,0 & 167,9 & 7,1 & 5,2 & 0,2 \\
\hline Floresta Est. Médio// & 911,2 & 38,5 & 865,0 & 36,5 & 872,8 & 36,9 & 660,7 & 27,9 & 512,2 & 21,6 \\
\hline Instalações Rurais & 0,0 & 0,0 & 0,0 & 0,0 & 0,0 & 0,0 & 0,0 & 0,0 & 3,8 & 0,2 \\
\hline Lagos, lagoas, repr & 5,2 & 0,2 & 5,2 & 0,2 & 5,2 & 0,2 & 1,2 & 0,1 & 3,4 & 0,1 \\
\hline Manguezal & 0,0 & 0,0 & 0,0 & 0,0 & 0,0 & 0,0 & 0,0 & 0,0 & 0,0 & 0,0 \\
\hline Mussununga & 0,0 & 0,0 & 0,0 & 0,0 & 0,0 & 0,0 & 0,0 & 0,0 & 0,0 & 0,0 \\
\hline Pasto Limpo & 13,5 & 0,6 & 12,7 & 0,5 & 99,7 & 4,2 & 168,7 & 7,1 & 800,1 & 33,8 \\
\hline Pasto Sujo & 852,9 & 36,0 & 954,3 & 40,3 & 682,4 & 28,8 & 558,0 & 23,6 & 578,2 & 24,4 \\
\hline Restinga Arbustiva & 0,0 & 0,0 & 0,0 & 0,0 & 0,0 & 0,0 & 0,0 & 0,0 & 0,0 & 0,0 \\
\hline Sistema Viário (prin & 2,3 & 0,1 & 2,3 & 0,1 & 2,2 & 0,1 & 2,8 & 0,1 & 0,5 & 0,0 \\
\hline Solo Exposto & 0,0 & 0,0 & 0,0 & 0,0 & 0,0 & 0,0 & 0,4 & 0,0 & 0,6 & 0,0 \\
\hline
\end{tabular}


A maior conversão de uso e ocupação do solo em Itamaraju (BA) ocorreu nas áreas de Floresta Estágio Médio/Avançado, que perderam quase $400 \mathrm{~km}^{2}(-16,8 \%)$, sendo sua maioria convertida em pastagem, especialmente entre 2002 e 2006. A Floresta Estágio Inicial sofreu redução de 4\% de 1990 até 1994, aumento nos dois períodos subsequentes (6\%) e redução de $6,8 \%$ entre 2006 a 2013, resultando em um déficit de $4,8 \%$.

A Secretaria do Meio Ambiente do Estado da Bahia (SEMA) lançou em 2018 um portal onde é possível acessar informações do monitoramento da cobertura vegetal do estado, relatando no Mapa de Áreas sem Vegetação Nativa que em Itamaraju $1868 \mathrm{~km}^{2}$ estavam desmatados em 2008. Enquanto neste trabalho foram contabilizados $1856 \mathrm{~km}^{2}$ sem floresta em estágio médio ou avançado até 2013. Estes resultados mostram a necessidade de aferir as metodologias de mapeamento e classificação quando se deseja análises mais específicas.

A classe Pasto Limpo, por sua vez, teve um incremento de 33\% em 19 anos, especialmente no último período, $26 \%$ de 2006 a 2013. Nota-se também que muitas das áreas de Pasto Sujo foram convertidas em Pasto Limpo, visto que a primeira classe apresentou uma redução de $11 \%$, o que pode ser constatado nos mapas.

Nos mapas, chama-se a atenção para a perda de comunidades aluviais, que apesar de apresentarem um aumento de 13\% entre 2002 a 2006, sofreram posteriormente uma redução de $12 \%$, que somada aos anos anteriores resultou em um déficit de 1,8\%. 0 que sugere a necessidade de um estudo mais aprofundado sobre essas áreas relacionandoas com a hidrografia.

\section{REFERÊNCIAS}

[1] IBGE. Cidades. Disponível em: < https://cidades.ibge.gov.br/brasil/ba/itamaraju/pes quisa/24/65644>. Acessado em julho de 2018.

[2] LATUF, M.O. Mudanças no uso do solo e comportamento hidrológico nas bacias do rio Preto e Ribeirão entre Ribeiros. Dissertação de Mestrado em Engenharia Agrícola, UFV, Viçosa, MG 103p. 2007.

[3] RIBEIRO, M.C.; SANTOS, J.S.; RIBEIRO, J.W.; MARQUES, A.; BORGES, R.; ANDRADE, D.;

\section{CONCLUSÃO}

A matriz principal da paisagem é a pastagem que conforme a classificação (pasto limpo e pasto sujo) ocupa $58 \%$ do território.

Houve bastante desmatamento no município entre 2002 e 2013. Os períodos considerados não permitiram identificar se as áreas desmatadas entre 2006 e 2013 dever-se-ão ser recuperadas conforme o novo código florestal, que obriga os proprietários a recomporem a vegetação desmatada após 2008.

Ainda que o geoprocessamento seja uma ferramenta muito importante para a gestão do uso e ocupação do solo, visitas a campo e o estudo de outras variáveis que influenciam os processos ambientais, sociais e econômicos que ocorrem no território são indispensáveis para o diagnóstico ambiental de uma região. A hidrografia e a topografia, por exemplo, permitirão verificar a ocupação das áreas de APP e áreas prioritárias para conservação dos recursos hídricos.

\section{AGRADECIMENTOS}

Os autores agradecem ao Fórum Florestal do Extremo Sul da Bahia pelos dados e ao CNPq pela concessão de bolsa de Iniciação Científica e de Mestrado.

SETTE, P.; LEAL, S.; WALDBURGER, T.; NOVAES, W.; ANDRADE, A.C. 2015. Monitoramento independente da cobertura vegetal dos municípios da área de influência da Veracel no Extremo Sul da Bahia para o ano 2013. Relatório técnico IBIO/ECONAMFI/LEEC/ECONECTA.

[4] SILVA, L.C.N.; FERNANDES, A.L.V.; OLIVEIRA, W. Análise de uso de ocupação do solo na microbacia Dom Tomaz no município de Três Lagoas-MS. In: SEMINÁRIO DE RECURSOS HIIDRICOS DA BACIA HIDROGRÁFICA DO PARAÍBA DO SUL, 1, 2007, Taubaté. Anais... Taubaté: IPABHi, 2007. p. 325-330. 


\section{Capítulo 4}

\section{RELAÇÕES DE BIODIVERSIDADE DA FAUNA EDÁFICA NO SOLO DA RESERVA EXTRATIVISTA DO RIO OURO PRETO-RO}

José Rodolfo Dantas de Oliveira Granha

Jorge Luiz Heráclito de Mattos

Ana Lucy Caproni

Alan da Silva Sampaio

Léo da Silva Sampaio

Ricardo Luis Louro Berbara

Resumo: Os microrganismos do solo, destacando-se os pequenos invertebrados, são os principais agentes da atividade bioquímica do solo, estando envolvidos diretamente em todos os processos biológicos e influenciando processos físicos e químicos, que antecedem os processos da fauna do solo. No Bioma amazônico onde os ecossistemas edáfico-florestais estão presentes, a fauna do solo, ainda constitui fator ecológico pouco elucidado até o momento. Os processos ecológicos conduzidos pelos organismos do solo, especialmente pela fauna edáfica, identificam-se bastante nos serviços ambientais reconhecidos hoje como um dos principais atributos da Biodiversidade do solo. Porém, com a ausência dos macroartrópodos edáficos, o trabalho dos microrganismos do solo terá uma redução em suas atividades bioquímicas, as quais são de profunda importância na participação do dreno de Carbono em excesso em nossa atmosfera, destinado à conversão em Matéria Orgânica no solo. A fauna do solo exerce um papel fundamental na fragmentação dos resíduos vegetais e na regulação indireta dos processos biológicos do solo, estabelecendo interações em diferentes níveis com os microrganismos. Este trabalho teve como objetivo avaliar a fauna do solo na Reserva Extrativista Rio Ouro-Preto, em três áreas agroextrativistas, no município de Guajará-Mirim-RO. Para a captura da fauna do solo utilizou-se o método do TSBF, com a obtenção de 60 amostras de solo em uma avaliação (setembro/2014), para a avaliação na Reserva Extrativista Rio Ouro-Preto, em uma área agroextrativista. Delinearam-se três octógonos de 17 metros de raio, formando um triângulo equilátero de 30 metros para as amostragens. Encontraram-se quatro grupos ou Ordens dominantes da macrofauna edáfica, às quais constituíram-se de Araneae, Hymenóptera (Família Formicidae), Pseudoescorpionídeas e Isóptera, na época seca. Para os octógonos com maiores quantidades de Serrapilheira encontrou-se a maior biodiversidade de macroartrópodos edáficos.

Palavras Chave: Invertebrados do solo; Biodiversidade do solo; Estabilidade do solo e Reserva extrativista. 


\section{INTRODUÇÃO}

A fauna do solo, particularmente a macrofauna, exerce um papel fundamental na fragmentação dos resíduos vegetais e na regulação indireta dos processos biológicos do solo, estabelecendo interações em diferentes níveis com os microrganismos (SWIFT et al., 1979).

A fauna e os microrganismos do solo são afetados pelas modificações impostas pelo uso agrícola do solo e, de um modo geral, os organismos do solo são afetados pela compactação e porosidade, diminuição no potencial hídrico ou excesso de água, queda na quantidade e qualidade do material orgânico e mudanças bruscas das condições climáticas.

Os microrganismos do solo são os principais agentes da atividade bioquímica do solo, estando envolvidos diretamente em todos os processos biológicos e influenciando processos físicos e químicos, os quais se integram aos processos da fauna do solo. No entanto, a fauna do solo pode influenciar os processos do solo por meio de duas vias principais: diretamente, pela modificação física da serrapilheira e do ambiente do solo, e indiretamente, pelas interações com a comunidade microbiana (GONZÁLEZ et al., 2001). Porém, os processos microbianos em geral serão intensificados após e durante as atividades da fauna edáfica (Benckinser, 1997).

Os invertebrados do solo, por sua vez, possuem uma capacidade enzimática limitada, restringindo-se à digestão de proteínas, lipídios e glicídios simples. Além de atuarem como reguladores da atividade microbiana, os invertebrados do solo agem como fragmentadores do material vegetal e também como engenheiros do ecossistema edáfico, modificando-o estruturalmente (Lavelle, 1997).

A caracterização e a descrição dos recursos de origem biológica no solo são quantificadas por intermédio do conjunto de informações estruturadas no campo da diversidade de espécies edáficas.

Portanto, é estratégica a elaboração de estudos objetivando a caracterização de métodos que sejam eficientes em avaliar a estabilidade e a resiliência edáfica, e mais do que a determinação da complexidade estrutural determinada pela interrelação ecossistêmica dos componentes bióticos de natureza edáfica, a determinação da Estrutura e natureza da complexidade e de como os mesmos a estrutura e a complexidade edáficas, se interrelacionam com os solos.

Um estudo abordando a fauna edáfica realizado na Resex Rio Ouro Preto/RO foi de suma importância para um melhor entendimento dos processos ecológicos ocorrentes nesta reserva. As informações obtidas nesta pesquisa possibilitarão uma integração na forma de inventário a qual será de extremo significado e poderá servir de informação para compor o quadro de dados pertinentes ao Plano de Manejo da Resex compondo assim, dados da biodiversidade do estrato marrom (solo), constituída dos macroartrópodos edáficos avaliados neste artigo.

Neste trabalho, por meio de parâmetros biológicos, foi possível avaliar a estabilidade, considerando o geossistema como padrão de referência, em unidades de conservação ambiental, enfatizada na integração dos aspectos biológicos (biodiversidade), e a interação entre os organismos e seu ambiente (ecologia), com princípios ecológicos associados aos conceitos de estabilidade, resistência e resiliência do ecossistema.

Para atingir este fim, determinou-se a biodiversidade da macrofauna edáfica e de suas implicações na determinação da qualidade e da estabilidade no estrato marrom (Solo e Serrapilheira).

\section{A FAUNA EDÁFICA}

Fauna edáfica é o termo utilizado para identificar a comunidade de invertebrados que vive permanente ou que passa um ou mais ciclos de vida no solo (Anderson, 1988).

Estes invertebrados são sensíveis ao manejo, aos impactos antropogênicos, bem como a propriedades inerentes ao próprio ecossistema, tais como mudanças climáticas (Silva et al., 2007) que, segundo Briones, Inesan e Picarce (1997), podem resultar no surgimento de novas espécies, no aumento do número de espécies mais tolerantes a temperaturas elevadas, bem como na migração para outros micro-habitats ou camadas, dormência ou extinção.

Decaens et al. (1998) descrevem que, as condições do solo, como o pH, conteúdo de nutrientes e matéria orgânica, e a estrutura da vegetação que determina a diversidade de 
micro-habitats e das condições de vida dos invertebrados, apresentando considerável influência sobre estes organismos do solo.

Nos processos de transformação da matéria orgânica há a disponibilização de nutrientes para as plantas nos quais estão envolvidos uma diversidade de organismos do solo, Stevenson e Cole (1999):

A abundância e diversidade dos organismos que compõem a teia alimentar decompositora determinam a velocidade e a magnitude de processos como a mineralização e imobilização desses nutrientes. Consequentemente, a assimilação de nutrientes pelas plantas e a produtividade das culturas podem ser fortemente afetadas pelos organismos do solo, mesmo quando é feita uma adubação mineral.

Apesar de os microrganismos serem os principais responsáveis pelo processo de mineralização dos nutrientes, é a fauna do solo que exerce um papel de regulação das populações microbianas. Cragg; Bardgett (2001) afirmam que a predação seletiva de fungos e bactérias, feita especialmente pela microfauna; a estimulação, digestão e disseminação de microrganismos ingeridos pela macrofauna e a fragmentação dos detritos realizada pelas meso e macrofauna interferem na decomposição da matéria orgânica e alteram a disponibilidade de nutrientes para as plantas.

As interações da fauna de solo com os microrganismos e a sua ação sobre a decomposição e ciclagem de nutrientes variam entre os diferentes grupos, sendo resultantes de características intrínsecas de cada grupo e, por vezes, de cada espécie da fauna de solo. A morfologia, aliada a características fisiológicas e comportamentais, é fundamental na determinação de onde e como a fauna de solo irá intervir na decomposição e na ciclagem de nutrientes. O tipo de deslocamento apresentado por um animal do solo, se preponderantemente horizontal, promove a redistribuição de nutrientes e matéria orgânica em uma determinada área, como no caso dos macroartrópodes que vivem na serapilheira, tais como isópodos e diplópodos (Correia; Oliveira, 2006).

Se esse deslocamento for preferencialmente vertical, essa redistribuição ocorre no perfil do solo, enquanto ocorre um aumento da heterogeneidade na área como um todo, com a formação de um mosaico de pequenas manchas de solo mais ou menos fértil. Um bom exemplo disso são os corós (larvas de besouros escarabeídeos), que se enterram no solo e levam consigo uma grande quantidade de matéria orgânica (Brown et al., 2001).

De acordo com Lavelle et al. (1992), a interação da fauna de solo com os microrganismos e as plantas ocasiona a modificação funcional e estrutural do solo, exercendo uma regulação sobre os processos de decomposição e ciclagem de nutrientes (Correia; Oliveira, 2006).

Os artrópodes da serapilheira podem digerir parte da biomassa microbiana ou desenvolver interações mutualísticas nos seus excrementos. Na mesofauna, os grandes artrópodes, que normalmente ingerem material orgânico puro, desenvolvem um mutualismo externo com a microflora baseado em um "rúmen externo" (Swift et al., 1979).

Como exemplo de transformador de serapilheira, temos os diplópodes, conhecidos vulgarmente como gongolos, são um grupo saprófago importante encontrado em todos os tipos de ecossistemas, sejam florestais, agrícolas ou de pastagens (Correia; Oliveira, 2006). Durante a passagem da serapilheira pelo tubo digestivo dos diplópodes, esse material é triturado, o que aumenta a sua superfície específica, umedecido e enriquecido com microrganismos (Correia; Oliveira, 2006).

Em ambientes estruturalmente complexos, como as florestas tropicais, as formigas são consideradas um dos principais componentes biológicos, compreendendo um terço da biomassa animal, junto com os cupins (Fittkau; Klinge, 1973). Elas formam a megadiversa família Formicidae (Insecta, Hymenóptera), a qual está constituída de 21 subfamílias, aproximadamente 300 gêneros e mais de 12400 espécies descritas (Agosti; Johnson, 2009).

As florestas tropicais são ecossistemas com elevada diversidade de processos ecológicos e maior diversidade biológica que qualquer outro ambiente terrestre (Bawa et al,. 2004). Isso está relacionado principalmente à alta abundância de espécies de insetos, e outros artrópodes, nessas áreas (Primack; Rodrigues, 2001).

Em ecossistemas tropicais, formicídeos são organismos dominantes em riqueza de espécies, abundância e diversidade em vários hábitats; sendo encontrados em todos 
os estratos florestais, utilizando inúmeros recursos e desenvolvendo funções relevantes na ciclagem de nutrientes (Hölldobler; Wilson, 1990).

A fauna de formigas pode estar associada até $50 \%$ à serapilheira em alguns locais tropicais uma vez que nela podem ser encontrados artrópodes em abundância, considerados potenciais presas para formigas; grande número de sítios para nidificação; e uma série de microhábitats que garantem condições favoráveis às formigas (Benson; Harada, 1988).

Com aproximadamente 2.800 espécies, os térmitas (cupim) pertencem à ordem Isóptera dos insetos que Myles (1988), explica basicamente que esse grupo é especializado em uma dieta à base de materiais lignocelulósicos $^{1}$, fato esse que os colocou evolutivamente em contato com um recurso trófico extremamente produtivo.

Lavelle et al. (1997) confirmam que de forma significativa os térmitas contribuem para o enriquecimento do solo adjacente por meio da construção de ninhos, que acumulam material fecal de importante qualidade, auxiliando na humificação da matéria orgânica do solo, e também pelo aumento da atividade microbiana tanto dentro como na própria área adjacente ao ninho, o que permite uma aceleração da ciclagem e a reabsorção dos nutrientes pelos produtores primários.

Os nutrientes retidos nas estruturas dos térmitas, ninhos e galerias retornam para 0 solo por erosão, possibilitando que ocorra um mosaico de nutrientes na paisagem, preservando a diversidade ecológica (Lavelle et al., 1992).

Black e Okwakol (1997) afirmam que algumas práticas agrícolas como aração, manutenção de monoculturas e utilização de pesticidas podem influenciar negativamente as

\footnotetext{
1 Lignocelulósicos são materiais fibrosos, que formam matrizes complexas constituídas de celulose, um rígido polímero de glicose, hemiceluloses, pectinas e outras gomas. Adicionalmente, essa matriz é impregnada com lignina, a qual pode ser considerada como uma cobertura de resina plástica. Os materiais lignocelulósicos são encontrados na biomassa vegetal, termo usualmente empregado para designar matéria orgânica produzida, tanto pelas espécies vegetais, como por seus resíduos. (Farage, R. M. P. 2009 105p.).
}

populações de térmitas preestabelecidas, fazendo com que a diversidade diminua drasticamente, o que possibilitaria a entrada de outras espécies, entre estas as espéciespragas e, mais importante, alguns processos ecológicos dos quais os térmitas são mediadores essenciais seriam claramente prejudicados.

Conforme estudo de Fragoso et al. (1997), estima-se que existam por volta de 7.254 espécies de Oligoqueta (minhocas), e, destas, 3.627 são terrestres, sendo a taxa anual de descrição de novas espécies próxima de 50 , normalmente descobertas em áreas tropicais.

As minhocas são importantes organismos do solo, que pertencem ao Domínio Eukarya, Reino Animália, Filo Annelida, Classe Clitellata e Subclasse Oligochaeta (Ruppert, 2005; Madigan et al., 2010). Apresenta corpo alongado e segmentado em forma de anéis, o que originou o nome do Filo (Ruppert, 2005).

Lavelle et al. (1997) afirmam que a ocorrência e a abundância das minhocas variam em um gradiente termolatitudinal, sendo normalmente excluídas das áreas mais secas, principalmente com pluviosidade abaixo de $800 \mathrm{~mm}$, e, apesar do número de espécies não se modificar muito ao longo desse gradiente, a diversidade funcional aumenta consideravelmente. O substrato utilizado como alimento e/ou moradia determina os tipos funcionais presentes e os mais comuns são as minhocas que se alimentam de serapilheira, as que se alimentam de matéria orgânica e as que vivem em galerias.

Pashanasi et al. (1992) verificaram que a presença de minhocas influenciou 0 crescimento de algumas espécies vegetais, enquanto outras espécies não foram influenciadas, 0 que se supõe estar relacionado com o tamanho e a distribuição do sistema radicular de cada planta, pois existe uma relação direta entre tamanho do sistema radicular e a absorção dos nutrientes liberados via coprólitos.

\section{UNIDADES DE CONSERVAÇÃO E A RESERVA EXTRATIVISTA RIO OURO PRETO}

A Lei 9.985 de 18 de julho de 2000, que instituiu o Sistema Nacional de Unidades de Conservação da Natureza - SNUC define que, as Unidades de Conservação estão divididas em dois grupos, a saber: as UCs de 
Proteção Integral e as UCs de Uso Sustentável.

As UCs de Proteção Integral visam à preservação da natureza, com uso apenas indireto de seus recursos naturais, e as UCs de Uso Sustentável visam compatibilizar a conservação da natureza com uso sustentável dos recursos naturais. As unidades de Proteção integral podem ser de 5 categorias no Brasil tais como: Estação Ecológica, Reserva Biológica, Parque Nacional, Monumento Natural e os Refúgios de Vida Silvestre. As unidades de uso sustentável são apresentadas em seis categorias como: Área de Proteção Ambiental, área de Relevante Interesse Ecológico, Floresta Nacional, Reserva Extrativista e Reserva de Fauna.

A Reserva Extrativista é definida e
caracterizada no Artigo 18 da Lei no
9.985/2000 como:

"(...) uma área utilizada por populações extrativistas tradicionais, cuja subsistência baseia-se no extrativismo e, complementarmente, na agricultura de subsistência e na criação de animais de pequeno porte, e tem como objetivos básicos proteger os meios de vida e a cultura dessas populações, e assegurar o uso sustentável dos recursos naturais da unidade".

As RESEX representam um marco na história da conservação da biodiversidade no país, inovando por terem sido criadas "de baixo para cima", ou seja, a partir de movimentos sociais organizados, e também, por tomar por base as características diferenciais de populações extrativistas de ecossistemas amazônicos de modo a articular às dimensões ambiental e fundiária (Almeida, 2003; Cunha, 2002; Millikan, 1994).

As quatro primeiras Resex federais foram criadas no ano de 1990, um ano depois do assassinato do líder sindicalista Francisco Alves Mendes Filho popularmente conhecido como "Chico Mendes". Dentre essas primeiras reservas, duas delas situam-se no Estado do Acre (Alto Juruá e Chico Mendes), uma no Amapá (Cajari) e uma em Rondônia (Rio Ouro Preto) (Brasil, 2013).

Não existe em outros Países, modelo de Unidade de Conservação com a categoria Resex, essa definição é especificamente Brasileira. A categoria surgiu como resposta a uma demanda organizada dos movimentos sociais encabeçados pelos "Povos da Floresta", que revindicavam a manutenção das áreas florestadas e a garantia de acesso e uso dos recursos naturais utilizados para extrativismo, especialmente seringa e castanha (Ibama/DIMAM, 2006).

A Reserva Extrativista (Resex), escolhida para a avaliação está localizada, conforme Plano de Manejo da Unidade, no extremo oeste do Estado de Rondônia, nos municípios de Guajará-Mirim e Nova Mamoré. A Reserva Extrativista do Rio Ouro Preto é circundada por outras áreas protegidas, formando um mosaico, com exceção do seu limite noroeste, onde se confronta com propriedades agropecuárias (Brasil, 2013).

No ano de 1990 o Governo Federal seguindo uma política de dar origem a reservas extrativistas no Brasil, deu inicio em 13/03/1990 pelo Decreto no 99.166 a criação da Reserva Extrativista do Rio Ouro Preto.

A Resex Ouro Preto limita-se ao norte com a Terra Indígena Lage e Parque Estadual de Guajará-Mirim, ao sul e oeste com a Reserva Biológica Estadual do Rio Ouro Preto, Reserva Extrativista Estadual do Pacaás Novos, e ao leste com a Terra Indígena Uru-Eu-Wau-Wau, localizada entre 6418' e 6516', Oeste e 1035' e 1103 Sul, abrangendo uma área de 204.583 hectares .

\section{SERRAPILHEIRA E SOLO}

A serrapilheira é a camada formada pela deposição e acúmulo de restos de vegetação, como folhas, arbustos, caules e cascas de frutos em diferentes estágios de decomposição, fazem parte dela também restos de animais e suas fezes em diferentes estágios de decomposição que reveste superficialmente o solo. Esta camada é a principal fonte de nutrientes para ciclagem em ecossistemas florestais, enriquecendo o solo, sustentando a vegetação presente nele. Fungos e bactérias agem na decomposição dessa matéria orgânica, mas outros seres vivos também contribuem com esse processo como: minhocas, lesmas, formigas dentre outros insetos (MAMAN et al., 2007). Segundo o conceito, citado dentre as diversas definições de solo, a que melhor se adapta ao levantamento pedológico é a do Soil Survey Manual (1984) (IBGE, 2007, p.31) solo é:

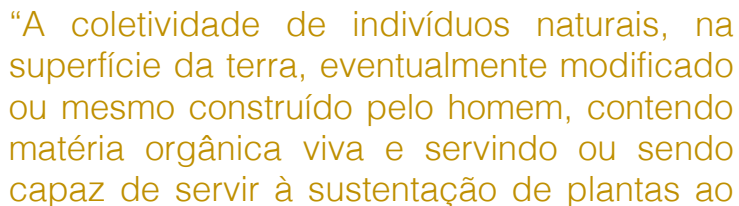


ar livre. Em sua parte superior, limita-se com o ar atmosférico ou águas rasas. Lateralmente, limita-se gradualmente com rocha consolidada ou parcialmente desintegrada, água profunda ou gelo. O limite inferior é talvez o mais difícil de definir. Mas, o que é reconhecido como solo deve excluir o material que mostre pouco efeito das interações de clima, organismos, material originário e relevo, através do tempo".

O solo e o suporte dos ecossistemas e das atividades humanas sobre a terra, seu estudo e imprescindível para o planejamento. Quando se analisa o solo, pode-se deduzir sua potencialidade e fragilidade como elemento natural, como recurso produtivo, como substrato de atividades construtivas ou como concentrador de impactos (SANTOS, 2004, p. 80).

Conforme descrito no Plano de Manejo, na RESEX, predominam os solos:

1. Aluviais (acumulados por detritos) recentes.

2. Solos aluviais mais antigos, de drenagem limitada, ou inundados periodicamente, sazonalmente saturados incluindo os gleysolos (várzeas contendo argila, argila e detritos).

3. Solos com drenagem impedida (igapós), que estão associados a florestas médias a baixas, semi-caducifólias e hidromórficas (muito úmidas).

4. Os solos antigos, provavelmente "ferralsols" (latossolos e ou podzolicos, profundos ou rasos), são localizados em áreas de boa a média drenagem de planície pleneplanadas. Estes solos em geral têm um pH de 5-5,6 com baixo nível de $\mathrm{Ca}$, alto nível de $\mathrm{Al}$, baixo nível de $P$ e níveis médios e baixos de matéria orgânica (BRASIL, 2013).

No Plano de Manejo da RESEX Rio Ouro Preto, consta que, as terras na sua quase totalidade, são consideradas inaptas para 0 cultivo de espécies anuais ou pastagens extensivas cultivadas, por não apresentar aptidão agrícola. Portanto, para a pequena agricultura é importante destacar a necessidade de práticas adequadas de adubação e escolha do tipo de cultura em função do solo existente (BRASIL, 2013).

O objetivo deste trabalho foi avaliar a fauna do solo da Reserva Extrativista do Rio Ouro Preto, no município de Guajará-Mirim/RO, como bioindicador ambiental no solo na época de máxima estiagem (setembro de 2014).

\section{METODOLOGIA}

\subsection{CARACTERIZAÇÃO DA ÁREA DE ESTUDO}

$\mathrm{Na}$ área de realização das coletas das amostras de Serrapilheira e de solos, foi dividida em três octógonos. Sendo que cada octógono tinha 17 metros de comprimento do centro até um dos vértices e uma distância de 40 metros um do outro.

O local das coletas das amostras distancia 40 km da cidade de Guajará-Mirim, acesso terrestre, e $3 \mathrm{~km}$ do barracão do Pompeu, acesso fluvial, localizando-se na propriedade do morador Sr. WM. Essa propriedade está localizada no Km 40 no ramal do Pompeu nas Coordenadas Geográficas S1052'49.80" W06504'26.03".

\subsection{AMOSTRAGEM E LOCAL DA COLETA}

As amostras de Serrapilheira e de solo foram realizadas utilizando amostragem aleatória simples (A.A.S.), nos espaços delineados dos três octógonos, conforme descritos a seguir:

O primeiro octógono ficou mais próximo à residência do morador, cerca de 30 metros de distância, e distante da floresta. O segundo octógono ficou a cerca de 70 metros de distância da residência do morador, à 40 metros distante do $1^{\circ}$ octógono e à 40 metros distante do 3o octógono. O terceiro octógono, ficou distante 110 metros da residência do morador, à 80 metros do 1 o octógono e à 40 metros do $2^{\circ}$ octógono. Assim, o 1o octógono é o mais próximo da residência do morador e o $3^{\circ}$ octógono é o mais próximo à floresta, sendo que o $2^{\circ}$ octógono ficou no centro entre a residência e a floresta (Figura 1). 
Figura 1 - Local das amostragens de serrapilheira e solos



Foram retiradas 20 amostras em cada octógono, sendo 10 amostras de Serrapilheira e 10 amostras de solo. Totalizando 60 amostras realizadas no mês de Setembro de 2014, sendo 30 amostras de Serrapilheira e 30 amostras de solo.

\subsection{AMOSTRAGENS E COMPUTAÇÃO DOS DADOS}

As amostragens de solo e de Serrapilheira, para identificação da macrofauna edáfica foram realizadas em setembro de 2014, pelo método Tropical Soil Biology and Fertility $(\mathrm{TSBF})^{2}$ modificado.

As amostras de solo e de serrapilheira foram acondicionadas em sacos de plástico e conduzidas ao Laboratório de Biologia e Química do curso de Gestão Ambiental da UNIR de Guajará-Mirim/RO, para triagem e identificação dos macroinvertebrados edáficos, por meio de catação manual. Os invertebrados do solo foram coletados com auxílio de lupa binocular e separados por grandes grupos taxonômicos. Após a triagem, os invertebrados foram acondicionados em placas de petri de plástico, com álcool a $70 \%$, para a identificação com auxílio de aparelhos estereoscópicos binoculares elétricos.

Foi também determinado os resultados da biodiversidade da macrofauna edáfica e de suas implicações na determinação da Qualidade e da Estabilidade no solo e na serrapilheira. As ordens da fauna do solo e da serrapilheira foram determinadas através de

\footnotetext{
${ }^{2} \mathrm{O}$ método (TSBF) é indicado sendo endossado pela Sociedade Internacional de Ciência do Solo e faz parte da União Internacional de Ciências Biológicas / 'O Homem e a Biosfera "da UNESCO Programa. ANDERSON, J. M.; INGRAM, J. S. I. Tropical soil biological and fertility: a handbook of methods. 2 ed. UNESCO, 1993. 221 p.
}

quatro índices de biodiversidade, segundo Odum (1988):

1) Índice de Shannon $\left(H^{\prime}\right)$, através da equação: $\mathrm{H}^{\top}=-\sum(\mathrm{Pi}$. Log $\mathrm{Pi})$, sendo que o valor resultante de $\mathrm{Pi}$, é correspondente a Probabilidade de ocorrência da i-ésima espécie, (ordem taxonômica) correspondente a equação: $\mathrm{Pi}=$ ni/ $\mathrm{N}$, onde ni é igual a população de determinada espécie (ou ordem taxonômica) e o N é correspondente a População Amostral total da comunidade de macroartrópodos edáficos. Este índice é referido por muitos como um excelente descritor de Estabilidade e da Qualidade do solo, sendo referido por alguns como um descritor de Heterogeneidade do ecossistema em avaliação.

2) Índice de Pielou (e), dado pela seguinte equação: $e=H / \log S$, sendo que $\log$ corresponde ao Logaritmo decimal e $\mathrm{S}$, ao número de Espécies (ou Ordens), encontradas nas amostras em estudo.

3) Índice de Simpson (Ds), dado pela equação: $\mathrm{Ds}=\sum(\mathrm{Pi})^{2}$;

4) Índice de Margalef ( Mgf), dado pela equação: $M g f=(S-1) / \operatorname{logN}$.

\section{RESULTADOS E DISCUSSÃO}

\subsection{GRUPOS TAXONÔMICOS}

As coletas de serrapilheira e de solos foram realizadas na época considerada de menores níveis de pluviosidade no mês de setembro de 2014. Utilizou-se do método denominado: Fertilidade da Biota dos Solos Tropicais TSBF, onde, foi realizada a triagem dos macroinvertebrados edáficos das amostragens de serrapilheira e de solos, sendo os espécimens identificados por grupos taxonômicos (a nível de Ordem) e 
também efetuada a contagem da população amostral encontradas em cada octógono.

\subsection{PRIMEIRO OCTÓGONO}

No primeiro octógono, foram quantificadas 10 amostras coletadas na serapilheira, onde foi registrada uma população de 49 indivíduos, constituída por 11 grupos de animais invertebrados distribuídos em que 6 Ordens da Classe Insecta tais como: Blattaria, Coleoptera, Collembolo, Hymenoptera, Isoptera e Thysanura, de 5 Ordens, pertencentes aos demais invertebrados como: Ácaro, Araneae, Diplura, Pseudoescorpionideae e Solifugae. Foram também quantificadas 10 amostras de solo constituída também de 11 grupos de animais invertebrados contendo 40 indivíduos com 9 grupos de animais invertebrados, de 5 Ordens da Classe Insecta tais como: Coleoptero, Diptero, Hemíptero-Homóptero, Hymenoptero, e Isoptero e de 4 Ordens dos demais invertebrados do solo tais como: Araneae, Diplura, Chilopodo e Pseudoescorpionideae.

$\mathrm{Na}$ serapilheira os espécimens pertencentes às ordens: Hymenoptero, Coleoptero e Isoptero, apresentaram $59 \%$ de toda população amostral. Nas amostras de solo, Isóptero, Larva de Coleóptero, Coleóptero e Hymenóptero apresentaram 67,5 \% da população amostral. Coleoptero seguido de Hymenoptero e este de Isoptero, respectivamente, foram as três Ordens mais abundantes representando cerca de $54 \%$ de toda população amostral considerando a Serrapilheira e o Solo em conjunto.

O índice de diversidade de Shannon foi maior na Serrapilheira $(0,88$ nats) do que no Solo $(0,79$ nats), sendo que o índice de Uniformidade de Pielou apresentou o mesmo valor (0,76 nats), tanto para a Serrapilheira como para o Solo. O índice de Dominância de Simpson foi de 0,14 nats considerado para o solo e de 0,16 nats para a Serrapilheira. O índice de Margalef foi maior para o solo $(6,25)$ do que para a Serrapilheira $(5,52)$, (Tabela 1$)$. Dessa forma podemos interpretar que ao considerar duas áreas edáficas (Serrapilheira e Solo), distintas, constituídas de mesmo número de Ordens (11), e de outro demais grupo taxonômico em que cada Ordem contenha uma única espécie, a área de menor população (Solo), apresentará o menor valor para a Dominância de Ordens ou de Espécies, pois o valor da Uniformidade de Pielou $(0,76)$, seja o mesmo para ambos os ambientes: Serrapilheira e Solo (Tabela 1). Caso o grau de Uniformidade também aumentasse para as amostras da Serrapilheira, relativa às amostras do Solo, então as amostras de Serrapilheira apresentariam um menor índice de Dominância do que o presente na situação atual, caso se mantenha a mesma quantidade de indivíduos. Da mesma forma o índice de Margalef indicou que em locais de menores densidades populacionais (como o Solo) o valor para este índice foi maior. Neste caso, indicou existir uma relação entre menor população e aumento da Estabilidade do componente biótico dos ecossistemas, indicando que a Serrapilheira tem um grau de estabilidade pouco menor do que no Solo, o que é indicado mesmo pelo maior valor apresentado pelo índice de Dominância de Simpson no local da Serrapilheira (Tabela 1). Assim, a propriedade de Heterogeneidade apresentada pelo índice de Shannon mostrou um maior valor para esta (heterogeneidade) acompanhada de um maior valor também para Dominância (cerca de 12,5\%) maior comparativamente ao Solo (Tabela 1).

A obviedade da Serrapilheira apresentar valores maiores para heterogeneidade e Dominância comparativamente ao Solo, indica existir uma estrutura com maior grau de desorganização do que no Solo, indicado sobretudo pelo valor menor do índice de Margalef na Serrapilheira. Dessa forma a interpretação sistêmica e simultânea dos quatro índices de Diversidade empregados neste trabalho, quando analisadas em conjunto proporcionam melhor compreensão e entendimento do funcionamento dos ecossistemas identificados nos níveis de Estabilidade a que passa ao menos o componente biótico dos ecossistemas. 
Tabela 1 - Índice de diversidade de Shannon ( $H^{\prime}$ ), Pielou (uniformidade e), Dominância de Simpson

(Ds) e Margalef (Mgf), numa área de plantio agroextrativista no solo e na serrapilheira, utilizando queimada de restos culturais e de plantas invasoras. Octógono 01.

\begin{tabular}{|l|l|l|}
\hline \multicolumn{1}{|l|}{ Índice /área } & Solo & Serrapilheira \\
\hline$H^{\prime}$ & 0,79 & 0,88 \\
\hline e & 0,76 & 0,76 \\
\hline Ds & 0,14 & 0,16 \\
\hline Mgf & 6,25 & 5,52 \\
\hline$N^{*}$ & 40 & 49 \\
\hline$S^{*}$ & 11 & 11 \\
\hline
\end{tabular}

${ }^{*} \mathrm{~N}$ e ${ }^{*} \mathrm{~S}$, respectivamente são o número de indivíduos para 10 amostras de solo e de 10 amostras para serrapilheira e o número de Táxons (ordem) destes indivíduos.

OBS: No local deste octógono foi realizada queimada, ficando agora em recuperação.

No local deste primeiro octógono foi realizada queimada, o que explica o comportamento anteriormente descrito relativos aos valores dos índices de diversidade anteriormente discutidos tornando ímpar lembrar que os efeitos de um incêndio nos ecossistemas ocasionam de imediato a perda de biodiversidade seguida de um incremento de perturbação identificada no incremento de dominância de ordens e grupos taxonômicos à qual, a dominância pode até mesmo ser a promotora de um incremento de heterogeneidade (maiores valores observados para o índice de Shannon).

\subsection{SEGUNDO OCTÓGONO}

No segundo octógono, com 20 amostras no total, sendo 10 de serapilheira, constituídas por 89 indíviduos distribuídos em 9 Ordens ou grupos taxonômicos de mesma categoria, contendo 6 ordens distribuídos em 78 indivíduos da Classe Insecta tais como: Blattaria, Collêmbolo, Coleoptero, Hymenoptero, Isoptero, Larva de Diptero e de três demais ordens de Invertebrados contendo somente 11 indivíduos tais como: Araneae, Pauropodo e Pseudoescorpionídeae (Tabela 2). As Ordens contendo maior número de indivíduos na Serrapilheira foram: Hymenoptero, seguido de Coleopetro e de Isoptero nessa respectiva ordem decrescente com 69 indivíduos, ou seja um montante de $77,5 \%$ da população total. Para o solo, as Ordens Isoptero e Hymenoptero e Coleoptero nessa respectiva ordem decrescente, apresentaram uma população total de 45 indivíduos o que representa o total de 81,8 \% relativo à população amostral total do Solo. Sua população era constituída por 10 Ordens (Tabela 2).

O índice de Diversidade de Shannon indicou um valor de 9,2\% maior para Serrapilheira e o índice de Uniformidade, de 11,6\% também maior na Serrapilheira comparativamente ao Solo. Consequentemente o valor indicado para o índice de Dominância de Simpson na Serrapilheira foi de $37,5 \%$ menor do que no Solo, e o do índice de Margalef, de 20,2\% menor na Serrapilheira comparativamente ao Solo. Foi empregada a queimada de restos culturais na Serrapilheira onde foi verificado um maior valor no índice de Uniformidade de Pielou, proporcionado pela queima de restos culturais considerada de baixo impacto à qual possivelmente proporcionou uma maior taxa de disponibilização de nutrientes favorecendo uma oferta maior de recursos alimentares para a biota edáfica. Assim uma maior presença de grupos generalistas na Serrapilheira seria favorável mostrado pelo menor valor do índice de Dominância de Simpson (0,15 nats na Serrapilheira) (Tabela 2). Mostrando assim, uma maior heterogeneidade (índice de Shannon com valor de 0,82 nats), para o local onde detivesse uma maior Uniformidade $(0,86$ nats), comparativamente com os valores amostrais obtidos no solo os quais apresentaram os valores de 0,76 nats para o índice de Shannon e de Pielou (Uniformidade), com 0,24 nats para a Dominância de Simpson e um valor maior para o índice de, Margalef (5,17 nats), cerca de $20,7 \%$ maior do que o encontrado na Serrapilheira (4,10 nats) (Tabela 2). Pode-se notar que este último índice estaria atribuindo um maior valor, relativo às Ordens de menores abundâncias proporcionais, às quais podem mesmo serem constituídas de indivíduos de Ordens pertencentes às espécies de maior raridade, observadas nas amostras populacionais do Solo.

Dessa forma a Dominância para este segundo Octógono estaria associada de forma antagônica à Heterogeneidade relacionada 
ao índice de Shannon, tanto no Solo como na Serrapilheira, o que constituiria a forma mais comum de relacionamento entre estes dois índices representantes de duas propriedades básicas da Diversidade: Heterogeneidade e Dominância (Tabela 2). Mas também que a relação da Dominância com uma terceira propriedade, a da Uniformidade também seja de forma associativa dada em geral sempre da forma recíproca, à qual se deu também nesse segundo caso (referente ao segundo Octógono) (Tabela 2). No local do octógono 2 , foi realizada a queimada antes dos locais dos outros dois octógonos.

Tabela 2 - Índice de diversidade de Shannon (H'), Pielou (uniformidade e), Dominância de Simpson (Ds) e Margalef (Mgf), numa área de plantio agroextrativista no solo e na serrapilheira, utilizando queimada de restos culturais e de plantas invasoras. Octógono 2.

\begin{tabular}{|c|c|c|}
\hline Índice/área & Solo & Serrapilheira \\
\hline$H^{\prime}$ & 0,76 & 0,82 \\
\hline $\mathrm{e}$ & 0,76 & 0,86 \\
\hline $\mathrm{Ds}$ & 0,24 & 0,15 \\
\hline Mgf & 5,17 & 4,10 \\
\hline $\mathrm{N}^{*}$ & 55 & 89 \\
\hline $\mathrm{S}^{*}$ & 10 & 9 \\
\hline
\end{tabular}

${ }^{*} \mathrm{~N}$ e $\mathrm{S}$, respectivamente é o número de indivíduos para 10 amostras de solo e de10 amostras para serrapilheira e o número de Táxons (ordem) destes indivíduos.

OBS: No local do octógono 2, foi realizada a queimada antes dos locais dos outros dois octógonos.

\subsection{TERCEIRO OCTÓGONO}

No 3 o octógono nas 20 amostras no total, sendo 10 de serapilheira, constituídas de oito Ordens contendo seis Ordens dos representantes da Classe Insecta contendo cerca de 32 indivíduos (ou espécimens), dados por: Blattaria, Collêmbolo, Coleóptera, Homoptero, Hymenoptero e Larva de Coleoptero com 37,5\%. O valor apresentado para a Ordem de maior quantidade de indivíduos em sua população amostral, foi a ordem Hymenoptera (família Formicideae); outros cinco indivíduos amostrais seriam pertencentes aos demais invertebrados nãoinsetos tais como Araneae e Diplura. As outras 10 amostras, de solo, foram constituídas de uma população amostral de 31 indivíduos em que apresentou 30 espécimens da Classe Insecta distribuídos de forma desigual dada para 6 Ordens desta classe taxonômica, sendo que 18 indivíduos fossem constituídos de uma única Ordem (Hymenoptera), a qual representa 58\% de toda população amostral existente. O número total de ordens do solo para este terceiro octógono foi de 7 (Tabela 3).
Com as amostras do solo apresentando uma menor população (31 indivíduos) e também com uma única Ordem taxonômica anteriormente constatada, constituída de 58\% da população total, foi no Solo o local detentor do menor índice de Shannon (Heterogeneidade), com valor de 0,60 nats, acompanhado do maior valor dado pelo índice de Dominância de Simpson, (0,38 nats), e também com um menor valor apresentado para o índice de diversidade de Margalef (4,02 nats) (Tabela 3). Antagonicamente à Serrapilheira, destituída de qualquer forma enviesada, definida por intermédio de um valor modal máximo para a dominância de alguma Ordem taxonômica, tal qual foi a dos Hymenopteros no Solo, apresentou, o menor valor para o índice de Dominância de Simpson (0,19 nats), em torno de $50 \%$ menor do que o valor para Dominância encontrado no Solo neste terceiro octógono, acompanhado de um valor para o índice de Shannon em torno de $24 \%$ maior e cerca de 42,5\% maior para o índice de Uniformidade encontrado na Serrapilheira (Tabela 3). Sendo que o valor de $9 \%$ maior dado para o índice de Margalef $(4,46)$, foi influenciado principalmente pelo maior número de Ordens, cerca de uma a mais, encontradas na Serrapilheira, equivalente a um acréscimo de $8,8 \%$ relativo à quantidade total de Ordens, no Solo (Tabela 3). Obviamente que a utilização da queimadas de plantas invasoras e de restos culturais no local favoreceram maiores níveis de Estabilidade representada pelo maior valor do índice de Shannon dado para a Serrapilheira, acompanhado do comportamento previsto 
pelos demais outros três índices verificados por Pielou (1983), e Margalef (1980) (Tabela 3). Inclusive tais níveis de Estabilidade poderiam estar associados a um menor grau de impacto das substâncias bioquímicas repelentes e antagônicas (e até mesmo alelopáticas) relacionadas às ervas nativas e invasoras no agroecossistema extrativista, desde que tais ervas estejam ausentes ou constituídas em menores populações através de um manejo de controle efetivo de tais ervas.

Tabela 3 - Índice de diversidade de Shannon (H'), Pielou (uniformidade e), Dominância de Simpson

(Ds) e Margalef (Mgf), numa área de plantio agroextrativista no solo e na serrapilheira, utilizando queimada de restos culturais e de plantas invasoras. Octógono 03.

\begin{tabular}{|c|c|c|}
\hline Índice/área & Solo & Serrapilheira \\
\hline$H^{\prime}$ & 0,60 & 0,79 \\
\hline $\mathrm{e}$ & 0,50 & 0,87 \\
\hline $\mathrm{Ds}$ & 0,37 & 0,19 \\
\hline $\mathrm{Mgf}$ & 4,02 & 4,46 \\
\hline $\mathrm{N}^{*}$ & 31 & 37 \\
\hline $\mathrm{S}^{*}$ & 7 & 8 \\
\hline
\end{tabular}

*N e S, respectivamente é o número de indivíduos para 10 amostras de solo e de10 amostras para serrapilheira e o número de Táxons (ordem) destes indivíduos.

\section{CONSIDERAÇÕES FINAIS}

No primeiro octógono foi realizada a prática da queimada, o que, em parte, explica o comportamento descrito relativos aos valores dos índices de diversidade, tornando ímpar lembrar que os efeitos de um incêndio nos ecossistemas ocasionaram de imediato a perda de biodiversidade seguida de um incremento de perturbação identificada no incremento de dominância de ordens ou de grupos taxonômicos à qual, a dominância pode até mesmo ser a promotora de um incremento de heterogeneidade (maiores valores observados para o índice de Shannon) conforme verificado neste primeiro octógono.

A Dominância, quantificada pelo índice de Simpson, observada, no segundo Octógono, estaria associada de forma antagônica à Heterogeneidade relacionada ao índice de Shannon, tanto no Solo como na Serrapilheira, o que constituiria a forma mais comum de relacionamento entre estes dois índices representantes de duas propriedades básicas da Diversidade: Heterogeneidade e Dominância. Mas também que a relação da Dominância com uma terceira propriedade, a da Uniformidade também seja de forma associativa dada em geral sempre da forma recíproca, à qual se deu também nesse segundo caso (referente ao segundo Octógono).

Obviamente que a utilização da queimadas de plantas invasoras e de restos culturais no terceiro Octógono favoreceram maiores níveis de Estabilidade com significados apresentado pelo maior valor do índice de Shannon verificado na Serrapilheira, sendo que de forma antagônica à Serrapilheira (destituída de qualquer forma enviesada), deu-se no Solo, a ocorrência de uma extrema dominância de alguma Ordem taxonômica tal qual foi a dos Hymenopteros (constituídos pelas famílias de Formicideae), sendo que a Serrapilheira apresentou em consequência disso, um menor valor para o índice de Dominância de Simpson (0,19 nats), em torno de $50 \%$ menor do que o valor para Dominância encontrado no Solo neste terceiro octógono, acompanhado de um valor dado para o índice de Shannon (heterogeneidade) em torno de $24 \%$ maior e cerca de $42,5 \%$ maior para o índice de Uniformidade de Pielou encontrado na Serrapilheira,. 


\section{REFERENCIAS}

[1] Almeida, M. W. B. A Luta dos Seringueiros na Amazônia. In: Seminário ANPOCS. Mesa redonda sobre Amazonas. Caxambu. Caderno de Resumos ANPOCS, 2003.

[2] Anderson, J.M. Invertebrate-mediated transport process in soils. Agriculture Ecosystems and Environment, Amsterdan, v.25, p. 5-14, 1988.

[3] Anderson, J.M.; Ingram, J.S.I. Tropical soil biology and fertility: a handbook of methods. Wallingford: CAB International, 2. ed. 221p. 1993.

[4] Agosti, D.; Johnson, N. F. Number of species recorded in Formicidae. In: D. Agosti; Johnson, N. F. Antbase. Available in the World Wide Web at: http://osuc.biosci.ohiostate.edu/hymenoptera/tsa.sppcount?the_taxon=Fo rmicidae. Acesso:[05/set./2014].

[5] Bawa, S. K. et al. Beyond paradise meeting the challenges in tropical biology in the 21st century. Biotropica, 36. p. 437-446. 2004.

[6] Benson, W. W.; Harada, A. Y. Local diversity of tropical and temperate ant fauna (Hymenoptera: Formicidae). Acta Amazonica, p. 275-289. 1988.

[7] Black, H. I. J.; Okwakol, M. J. N. Agricultural intensification, soil biodiversity and agroecosystem function in the tropics: the role of termites. Applied Soil Ecology, Amsterdam, v. 6, p. 37-53, 1997.

[8] Brasil. Decreto № 99.166, de 13 de março de 1990. Cria a Reserva Extrativista do Rio Ouro Preto.1990.

[9] Brasil, Lei 9985 de 18 de julho de 2000. Sistema Nacional de Unidades de Conservação. 2000.

[10] Brasil. Ministério do Meio Ambiente. Diretoria de Criação e Manejo de Unidades de Conservação - DIMAN. Plano de Manejo Reserva Extrativista do Rio Ouro Preto. Brasília, DF, 2013.

[11] Briones, M.J.I. et al. Effects of climate change on soil fauna; responses of enchytraeids, Diptera larvae and tardigrades in a transplant experiment. Applied Soil Ecology, Amsterdam, v.6, p.117-134, 1997

[12] Brown, G.G. Diversidade e função da macrofauna no sistema edáfico agrícola. In: CONGRESSO BRASILEIRO DE CIÊNCIA DO SOLO, 28, 2001, Londrina. Anais...Londrina: Sociedade Brasileira de Ciência do solo. p.56. 2001.

[13] Correia, M. E. F.; Oliveira, L. C. M. Importância da fauna de solo para ciclagem de nutrientes. Cap.4, p. 77-93, 2006.

[14] Cragg, R. G.; Bardgett, R. How changes in soil faunal diversity and composition within a trophic group influence decomposition processes.
Soil Biology and Biochemistry, Oxford, v. 33, p. 2073-2081, 2001.

[15] Decaens, T. et al. Factors influencing soil macrofaunal communities in post-pastoral successions of Western France. Applied Soil Ecology, Amsterdam, v. 9, p.361-367, 1998.

[16] Fragoso, C. et al. Agricultural intensification, soil biodiversity and agroecosystem function in the tropics: the role of earthworms. Applied Soil Ecology, Amsterdam, v. 6, p. 17-35, 1997.

[17] Fittkau, E. J., Klinge, H. The biomass and trophic structure of the Central Amazonia rain forest ecosystem. Biotropica, 5: 2-14. 1973.

[18] González, G. et al. Soil ecological interactions: comparisons between tropical and subalpine forests. Oecologia, New York, v. 128, p. 549-556, 2001.

[19] Hölldobler, B.; Wilson, E. O. The Ants. Cambridge, The Belknap Press of Havard University Press, 731 p. 1990.

[20] Ibge, 2007. Cidades. Guajará-Mirim. Dados Estatísticos. Disponível em: www.ibge.gov.br/cidadesat/topwindow.htm?1 Acesso: [07/out./2014].

[21] Lavelle, P. et al. The properties of soils in the humid tropics. In: LAL, R.; Sanchez, P. A., (Ed.). Myths and science of soils of the tropics. Madison: Soil Science Society of America/American Society of Agronomy. p. 157-185. 1992

[22] Lavelle, P. Faunal activities and soil process: strategies that determine ecosystem function. Advances in Ecological Research, London, v. 37, p. 93-132, 1997.

[23] Madigan, M. T. et al. Microbiologia de Brock. Porto Alegre: Artmed. 12aㅡ ed. 1160 p. 2010.

[24] Maman, A.P. et al. Produção e acúmulo de serapilheira e decomposição foliar em mata de galeria e cerradão no sudoeste de Mato Grosso. Revista de Ciências Agro-Ambientais, Alta Floresta, v.5, n.1, p.71- 84, 2007.

[25] Margalef, R. La Biosfera: entre la termodinámica y el juego. Barcelona: Omega. 214p. 1980

[26] Millikan, B. Levantamento Sócio econômico da Reserva Extrativista do Rio Ouro Preto. Porto Velho, IEA, Mimeo. 1994.

[27] Myles, T. G. Resource inheritance in social evolution from termites to man. In: C.N. Slobodchikoff, C. N., (Ed.). The ecology of social behaviour. San Diego: Academic. p. 379-423. 1988.

[28] Pashanasi, B. et al. Effect of inoculation with the endogeic earthworm Pontoscolex corenthrurus (Glossoscolecidae) on N availability, soil microbial biomass and the growth of three tropical fruit tree seedlings in a pot experiment. Soil 
Biology and Biochemistry, Oxford, v. 24, p. 16551660, 1992.

[29] Pielou, E .C. Population and community ecology. Principles and Methods. 4 ed. Gordon; Breach, New York. 424p. 1983.

[30] Primack, R. B.; Rodrigues, E. Biologia da conservação. Londrina, Editora Planta, 328 p. 2001.

[31] Ruppert, E. E. et al. Zoologia dos Invertebrados: uma abordagem funcional-evolutiva. 7. ed. São Paulo, Roca, 1145p. 2005.

[32] Santos, R. F. Planejamento ambiental: teoria e prática. São Paulo: Oficina de Textos. P. 80-184. 2004
[33] Silva, R. F. et al. Macrofauna invertebrada edáfica em cultivo de mandioca sob sistemas de cobertura do solo. Pesquisa Agropecuária Brasileira, v.42, p.865-871, 2007.

[34] Stevenson, F. J.; Cole, M. A. Cycles of soil: Carbon, nitrogen, phosphorus, sulfur, micronutrients. New York: John Wiley \& Sons. 427 p. 1999.

[35] Swift, M. J. et al.Decomposition in Terrestrial Ecosystems. Decomposição em Ecossistemas Terrestres. Vol. Vol. 5, University of California Press, Berkeley, pp: 167-219.5, University of California Press, Berkeley, pp: 167219. 1979 


\title{
Bapítulo 5
}

\section{BIODIVERSIDADE DA FAUNA DO SOLO EM TRES PLANTIOS DE CANA-DE-AÇÚCAR EM ITAPIRA/SP}

\author{
José Rodolfo Datas de Oliveira Granha \\ Ana Lucy Caproni \\ Jorge Luiz Heraclito de Mattos \\ Sander Luis Stella \\ Marina Granha Alfenas Vieira
}

Resumo: Este trabalho objetivou-se de uma avaliação pontual no solo em três tipos de cultivos de cana-de-açúcar, em larga escala para a produção industrial, no final do mês de Agosto de 2013, em Itapira/SP. Analisaram-se as características da ecologia de comunidades dos Artrópodos. As influências teóricas da perturbação de natureza agrícola na produtividade de cada cultura em crescimento e do efeito da biota edáfica (Artrópodos), sob a influência de um plantio sem colheita, da mecanização agrícola e da queima na lavoura da cana-de-açúcar nos ecossistemas hipo-edáficos (Solo) e na serrapilheira. A fauna edáfica na Região rural de Itapira-SP, cultivos de Cana-de açúcar abriga muitos dos Artrópodos edáficos, responsáveis pela estruturação dos solos tropicais, sendo que é na Serrapilheira que se dá a ocorrência de uma maior abundância proporcional, ou relativa à nível de qualquer táxon, como o de Ordem. A biodiversidade da fauna edáfica obtidas de 60 amostras de solo da região hipoedáfica e da serapilheira foi calculada pela relação entre o número complementar do número de espécies (ou de táxon quaisquer) relativo ao logaritmo do número populacional de um conjunto de amostras representativos das três áreas de estudo em questão, é indicada pelo índice de Margalef. $\mathrm{O}$ índice de Dominância de Simpson também empregado neste estudo e juntamente com o de Margalef, foram favoráveis aos monitoramentos e acompanhamentos das características Ecológicas inerentes a estes, para melhor compreensão das relações ecológicas e a influência da perturbação de natureza agrícola considerados neste estudo. O efeito da biota edáfica, particularmente dos Artrópodos, sob a influência da mecanização agrícola e sobretudo da influência da queima empregada na lavoura da Cana-de-açúcar pode ser apontada como a principal vilã da degradação ambiental, relativamente pôde ser confirmado neste estudo. Porém não menos como no método utilizado no Plantio Mecanizado, responsável, em grande parte, pela subtração da abundância populacional de segunda e terceira ordens consideradas neste estudo.

Palavras-chave: Biodiversidade do Solo; Estresse e Perturbação Ambiental, Índices de Biodiversidade, Cana-de-açúcar. 


\section{INTRODUÇÃO}

É reconhecido que existe ainda poucas espécies da fauna do solo identificadas nas regiões tropicais e subtropicais. Apesar da existência das limitações químicas registradas nesses solos, existem várias Ordens e de outros táxons em considerável quantidade (BECKER; BIGARELLA; PASSOS, 1996; BARRET; ODUM, 2008).

Uma grande biodiversidade biológica, nesse estudo, dos Artrópodos edáficos pode ser encontrada nas camadas mais superficiais do solo, entre 20 e $30 \mathrm{~cm}$ de profundidade. Esta camada de solo, denominada hipo-edáfica, geralmente situada no Horizonte orgânico, ou $\mathrm{O}$, possui em sua maioria, abaixo o Horizonte A, e acima o denominado de serrapilheira. A serrapilheira é constituída de restos vegetais liberados ao longo do tempo e acumulados na superfície edáfica (BRUSSAARD; MOREIRA; SIQUEIRA, 2008).

É na Serrapilheira que se dá a existência de maior abundância proporcional, ou relativa tanto das espécies ou de quaisquer taxa em sua devida consideração (BRUSSAARD; MOREIRA; SIQUEIRA, 2008).

A presença de uma abundância vegetacional nestas regiões proporciona proteção contra a perda de solo e de nutrientes considerados críticos, pois já é reconhecido que a dinâmica dos nutrientes nas Florestas Tropicais, são completamente dependentes dos diversos mecanismos de fitociclagem até o momento não completamente compreendidos (TERBORGH, 1992; MASON, 1980).

Estes mecanismos ainda mostram uma estreita e delicada relação de conservação de seus estoques de nutrientes em intensa ciclagem do solo para a planta, e vice-versa, e são também como porta de entradas à atmosfera e à sua porção pluvial e fluvial. Esta porção é constituída por inúmeros rios e outros cursos de água existentes nas regiões tropicais, com um regime de regular pluviosidade nessas áreas em relação a outros biomas do planeta. E nessa rapidez de circulação de nutrientes é que se fornece a necessária garantia dos funcionamentos ecossistêmicos nessas regiões, bem como de seus serviços ambientais proporcionados pelas florestas. Estes serviços influenciam também como pré-concepção de existência diversidade das paisagens, que em interação com os elementos geológicos e geomorfológicos, proporcionaram um melhor entendimento dos aspectos funcionais das paisagens tropicais (TERBORGH, 1992).

\subsection{A REDUNDÂNCIA DE BIODIVERSIDADE, A HIPOTESE DO DISTÚRBIO INTERMEDIÁRIO (HDI) E A TEORIA DO CICLO DA RENOVAÇÃO DE SCHUMPETER}

Terborgh em 1992, assinalou que a garantia para um padrão de biodiversidade no planeta somente poderia ser fruto de um mecanismo recentemente descoberto e denominado de hipótese do distúrbio intermediário (HDI), o qual estabelece uma destruição ecossistêmica parcial de baixo impacto, como por exemplo, das quedas das árvores mais velhas num ambiente florestal tropical, proporcionando através desse fato o relacionamento de alguma reorganização, assim denominada através do ciclo da renovação de Schumpeter, proporcionando dessa forma consideráveis modos e alternativas possíveis de incrementar a biodiversidade em seus aspectos funcionais realizados nos ecossistemas (FOLKE et al., 1997).

O episódio das quedas arbóreas ocorridas de forma natural, a qual se apresenta na fase do ciclo da renovação, denominada de liberação, pode ser entendido como o fato principal desencadeador de outros, que por meio de um adicional de mais três novas fases, começa pela fase de explotação. A fase de explotação caracteriza-se pela presença de arranjos das 12 interações populacionais observadas em ecologia de comunidades, tal como a interação de competição tanto da biota, onde a restauração tanto de seu constituinte abiótico tal como o do solo inerte ou de seu componente biótico, incluindo o substrato serrapilheira, o que proporcionará às condições de incremento na Redundância de espécies ou de táxons funcionais dos invertebrados edáficos na fase posterior à da explotação (a segunda fase deste ciclo, denominada de conservação). Desde que hajam condições adequadas estabelecidas pela estabilidade, persistência e resiliência dos ecossistemas tropicais, garantindo a disponibilidade de seus nutrientes através do reservatório de $\mathrm{MO}$, relacionados a esta fase de conservação, em que deve-se considerar também a presença de abrigos ou habitats, os quais são necessários ao estímulo da redundância de espécies dos invertebrados edáficos. 
Esta redundância se relaciona a estabilidade real adquirida pelo ecossistema e também dos táxons e dos grupos funcionais que interajam entre si sem ocasionar repentinas e significativas mudanças drásticas nos ecossistemas no intuito de comprometer de vez sua estrutura, fato que tornaria ineficaz $e$ até mesmo inoperante o referido ciclo da renovação (MATTSON, 1977). O substrato serapilheira é o responsável tanto pela vantagem de considerável quantidade de abrigo quanto de alimento não somente para as Plantas, pois que este constitui um importante compartimento de nutrientes depois de sua profunda e complexa transformação físico-química ocasionada primariamente pela fauna edáfica como de forma secundária pela não-edáfica, e de suas complexas transformações bioquímicas dadas pelos microrganismos edáficos no substrato da Serrapilheira e/ou na camada superficial do solo ( MOREIRA; SIQUEIRA 2009).

\subsection{A FAUNA DO SOLO NOS TRÓPICOS}

Os animais que integram os solos tropicais possuem a peculiaridade de ocorrência de ampla distribuição posicionada em mosaicos de habitats de intensa variabilidade, os quais são resultantes da elevada biodiversidade presente nos trópicos. A presença de resíduos vegetais fibrosos, constituídos em sua maior parte por ligninas e celulose de difícil decomposição, mostram uma rápida transformação desses materiais, mesmo quando 0 produto resultante dessa degradação vem a se constituir nos subprodutos orgânicos que conserve quase as suas estruturas originais constituídas de celulose e de lignina, formando um húmus tipo Mull. O que ocorre preferencialmente nos diversos solos tropicais e subtropicais são os mais variados tipos de latossolos, com a presença dos artrópodos de duas ordens taxonômicas da classe insecta, que são a dos Hymenópteros (Família Formicideae formigas) e os da Ordem dos Isópteros (várias famílias principalmente a dos Kalodermes Cupins), os quais são os principais e maiores integrantes zoológicos em termos de biomassa existentes nos trópicos especificamente no interior do solo (COLLINS, ROBERTSON, KLUG, 1995; VARGAS; HUNGRIA, 1997). Ambos, recentemente, foram denominados de engenheiros do solo, devido a sua importância para a formação da estruturação física dos solos, os quais seriam também um dos principais componentes na formação destes solos denominados de ferralíticos ou Oxissols (os latossolos, argissolos, planossolos e outros da mesma categoria), conforme a classificação Norte Americana de taxonomia dos solos (BECKER; BIGARELLA; PASSOS, 1996). As formigas e os cupins formam imensas galerias subterrâneas que revolvem o solo de forma natural, oferecendo a este uma resistência aos processos de eluviação e lixiviação dos seus constituintes materiais, principalmente os nutrientes integrantes dos minerais do solo responsáveis pela existência da planta na biosfera. Este processos permitem então, que os nutrientes fiquem retidos nas camadas mais superficiais do solo, possibilitando uma maior acúmulo e possibilidade de participarem por inúmeras vezes no processo da ciclagem ou fitociclagem de nutrientes minerais no sistema solo-planta-atmosfera, possibilitando assim a manutenção da biomassa e da biodiversidade das plantas e das faunas edáfica não-edáfica, existente na serrapilheira e no solo (BECKER; BIGARELLA; PASSOS, 1996; VARGAS; HUNGRIA, 1997).

A grande importância dessas duas ordens de insetos, vem a se integrar a um terceiro grupo de animais de invertebrados da classe insecta, que pertencente ao grupo dos oligochaetas, os quais vem a se constituir em espécies de minhocas, que segundo Lavelle (2000), denominadas de engenheiros do solo, grupo ao qual se integra os cupins e formigas anteriormente citados. O aspecto funcional desse grupo de animais que além de estabelecer câmaras subterrâneas que oferecem resistência à Eluviação ou à translocação de material de constituição da estrutura do solo e de seus nutrientes, é a de formar uma maior rede de drenagem responsável pela redução da velocidade e fluxo de água no solo a uma determinada área de escoamento.

Também que estes engenheiros do solo São favoráveis a um incremento de volume da água infiltrada no solo e de seu consequente escoamento vertical, relacionado à diminuição da energia destrutiva nos agregados do solo, através do incremento da porosidade edáfica, ocasionado pela intensificação das atividades destes constituintes da fauna edáfica no solo, responsáveis pela agregação, incremento e manutenção da estabilidade no solo. Dessa forma, a presença dos engenheiros do solo, os quais são favorecedores de uma redução das forças erosivas, responsáveis pela perda 
de biodiversidade e da produtividade, nos ecossistemas edáficos, destacadamente a vegetal, favorece a presença do ecossistema terrestre com integração adequada entre a planta, a fauna, a água e o solo em questão. Além dos denominados engenheiros do solo, encontram-se em menores abundâncias proporcionais os seguintes grupos ou ordens de Artrópodos nos ecossistemas terrestres tropicais: aranhas, Miriápodos, Centípodos, Colêmbolos, Orthópteros, Coleópteros, Dípteros, Lepidópteros, Dipluros, Proturos, Diplópodos, Symphyllas, Thysanópteros, Homópteros, Hemípteros, ácaros do solo, Moluscos, Isópodos dentre outros tais como como pseudoescorpiões, Mantódeos, Odonatas, Nematóides e Dermápteros, constituem os principais grupos e ordens que aparecem nos solos tropicais em diferentes proporções e constituições de acordo com a característica e particularidade do ecossistema de seus habitats (BECKER; BIGARELLA; PASSOS, 1996). A abundância populacional de Colêmbola e de ácaros edáficos, dependem fortemente da textura e do tipo de solo. Ambos os taxa necessitam de espaços porosos para todas suas atividades bio-ecológicas e raramente são capazes de cavar. Em geral a população é alta quando em solos arenosos como os Latossolos, quando comparados com solos com maiores teores de argila, tais como os Argissolos, os Alissolos, e os Planossolos denominados de antigos Podzólicos (BECKER; BIGARELLA; PASSOS, 1996). Uma mínima biodiversidade, registrada nos ecossistemas edáficos na maioria das vezes, consistirá numa abundância proporcional de características dominantes com sua frequência de ocorrência constituída de poucas espécies, as quais em geral, são mais capazes de enfrentar o estresse e a perturbação ecológica e/ou ambiental que se impõem no momento de baixa biodiversidade.

Em outras ocasiões, a supressão do estresse permitirá uma cíclica recuperação populacional, e também de táxons, assim como uma restauração da funcionalidade ecossistêmica, fazendo mais frequentemente que o sistema ecológico da comunidade em avaliação cresça de forma positiva. De forma inversa ao crescimento da Dominância de espécimens agrupados por suas Ordens taxonômicas, a comunidade e suas populações, serão submetidas a um consequente e sucessivo crescimento da Heterogeneidade populacional da comunidade em avaliação, o qual será relativo ao valor apresentado pelo logaritmo das espécies totais, variadas em intervalo de tempo, sucessivos destes eventos em variação (BARRET; ODUM, 2008).

Assim, pode-se imaginar um Sistema de Retroalimentação, "subjetivo", invisível, mas tão presente e consistente na realidade, que sua presença, calcada na Teoria da Informação de Claude Shannon, objetiva o principal, o qual seja a cognição cibernética da natureza da comunidade em estabelecer regras de controle populacional, reguladoras importantes do Ecossistema, através da simples interrelação estimuladora da Biodiversidade (BARRET; ODUM, 2008).

Este trabalho objetivou-se de uma avaliação pontual no solo em três tipos de cultivos de cana-de-açúcar, em larga escala para a produção industrial, no final do mês de Agosto de 2013, em Itapira/SP. Analisou-se as características da ecologia de comunidades dos Artrópodos edáficos à fim de se compreender através dessas relações de natureza cibernética, por intermédio de dois descritores de biodiversidade, a influência teórica da perturbação de natureza agrícola na produtividade de cada cultura em crescimento e do efeito da biota edáfica (Artrópodos), sob a influência da mecanização agrícola e da queima na lavoura da cana-de-açúcar, nos ecossistemas hipoedáficos (Solo) e no ecossistema serrapilheira.

\section{MATERIAL E MÉTODOS}

\subsection{DESCRIÇÃO DA ÁREA E AMOSTRAGENS}

Para este estudo foi monitorada a diversidade da biota do solo, em três áreas localizada na usina de refino açúcar e de destilação de álcool, que está localizada no estado de São Paulo, no município de Itapira. Situada nos paralelos $22^{\circ} 26^{\prime} \mathrm{OO}$ ' de latitude sul e pelos meridianos $46^{\circ} 49^{\prime} 18^{\prime \prime}$ de longitude a oeste de Greenwich, num sopé de planalto, iniciando elevações do acidentado relevo da divisa do estado de São Paulo com Minas Gerais, situado numa altitude média de 643 metros acima do nível do mar. Os solos predominantes são os Latossolos e Argissolos. O clima é o tropical de altitude denominado de Cwa na classificação de Köppen. A região apresenta uma pluviosidade média de 1,6 metros anuais com temperatura anual média de $22^{\circ} \mathrm{C}$ 
A diversidade da biota foi avaliada em amostras coletadas durante o mês de setembro de 2013 (final da época de inverno), em três áreas onde cada com aproximadamente um hectare, abrangendo três subdivisões de manejo: cultivo em Plantio Mecanizado (PM), cultivo em plantio de área de queima (PAQ) e cultivo em plantio novo sem colheita (PNSC).

\subsection{DETERMINAÇÃO DA DIVERSIDADE DE ESPÉCIES}

Os artrópodos da mesofauna no solo e serrapilheira foram coletados por um coletor cilíndrico de metal de volume 0,9 dl., o qual abrange uma faixa de profundidade de $10 \mathrm{~cm}$ no solo. Os artrópodos foram separados através do método TSBF, sendo que para identificação de alguns artrópodos incluiu-se um copo de vidro à fim de capturar cada espécimen de Artrópodo que fosse fugidio, tentando se esconder, ou sair fora do campo visual de identificação.

A identificação taxonômica dos Artrópodos foi feita em nível de ordem.

Os dados gerais obtidos foram avaliados quanto a:

1) Abundância da comunidade (número de indivíduos de cada Ordem/população total, correspondente ao $p$.

2) Índice de dominância de Simpson $(\lambda s)$, conforme descrito por Pielou (1977).

$$
\lambda=\sum_{i}^{S_{o b s}} p_{i}{ }^{2} \text { Onde: } \quad p_{i}^{2}=\left(\frac{N_{i}}{N_{T}}\right)^{2}
$$

$\mathrm{N}_{\mathrm{i}}$ é o número de indivíduos da l-ésima espécie e $\mathrm{N}_{T}$ o total de indivíduos na amostra.

3) Índice de Margalef, conforme também descrito por Pielou, 1977 :

Marg = S / Log N onde S, indica o número de espécies e $\mathrm{N}$ a população total amostral.

4) Avaliação do aspecto funcional da biodiversidade no solo e serrapilheira, nos canaviais.

\section{RESULTADOS E DISCUSSÃO}

\subsection{AVALIAÇÃO DOS GRUPOS TAXONÔMICOS NO ECOSSISTEMA HIPO-EDÁFICO}

Para a área do Plantio Mecanizado (PM), Plantio na Área de Queima (PAQ) e no Plantio Novo Sem Colheita (PNSC) foram registrados 15 grupos de invertebrados -Artrópodos do solo, na região superior do solo considerada até uma profundidade máxima de $10 \mathrm{~cm}$, região neste estudo denominado de ecossistema hipo-edáfico, constituída dos grupos: Araneae, Acarineae, Colêmbolo, Dipluro, Symphila, Diplópodo, Chilópodo, Thysanóptero, Proturo, Hymenóptero (família Formicideae), Blattodeo, Díptero, Coleóptero, larvas de Coleóptero e de Lepidóptero.

\subsubsection{PLANTIO MECANIZADO}

Para a área do plantio mecanizado, foram registrados alguns invertebrados na região superior do solo, tendo como representantes sete grupos taxonômicos constituídos de 23 indivíduos encontrados de: Proturo, Dipluro, Diplópodo, Araneae, Hymenóptero e Colêmbolo. O representante mais abundante foi do grupo dos Diplópodos com 11 indivíduos equivalentes a $50 \%$ da população total, seguido de 4 indivíduos pertencentes ao grupo das araneaes com cerca de $18 \%$ da população total e $32 \%$ de Hymenóptero (Formicideae), Proturo, Dipluro, Colêmbolo e de 2 indivíduos de identificação desconhecida (Tabela 1). 
Tabela 1 - Distribuição populacional de oito amostras numa área de Plantio Mecanizado (PM), de Cana-de-açúcar (Sacharum officinalis spp), no ecossistema hipo-edáfico com sete grupos taxonômicos constituídos de 23 indivíduos.

\begin{tabular}{|c|c|c|c|c|c|c|c|c|c|}
\hline Ordens taxonômicas & \multicolumn{9}{c|}{ Amostras } \\
\hline Colêmbolo & 1 & 2 & 3 & 4 & 5 & 6 & 7 & total \\
\hline Hymenóptero(formicidae) & - & - & - & - & - & - & 1 & - & 1 \\
\hline Araneae & - & - & - & 1 & - & - & - & - & 1 \\
\hline Dipluro & - & - & - & 1 & - & 2 & - & 1 & 4 \\
\hline Diplópodo & - & - & 1 & - & - & - & 1 & - & 2 \\
\hline Proturo & - & - & - & 2 & 2 & 6 & 1 & - & 11 \\
\hline ENI & - & 2 & - & - & - & - & - & - & 2 \\
\hline Total & - & - & - & - & - & 2 & - & - & 2 \\
\hline & 0 & 2 & 1 & 4 & 2 & 10 & 3 & 1 & 23 \\
\hline
\end{tabular}

Diplópodo e Araneae constituem 2/3 ou mais de $68 \%$ da população total nessa área (PM), o que constitui uma elevada dominância dos grupos taxonômicos em destaque, demonstrando que esse sistema de plantio suportou um elevado estresse ambiental devido à intervenção produtiva altamente perturbadora em termos ecológicos. Sendo que em três amostras, das oito analisadas, demonstraram a presença de Aranea e de Diplópodos, os quais são os representantes adequados de uma perturbação ambiental, pois ambos os grupos são predadores, o que dá indício de ser um bom indicador de perturbação e de perda de estabilidade ecossistêmica, devido às condições rudes em que é imposta no Plantio Mecanizado.

\subsubsection{PLANTIO NA ÁREA DE QUEIMA}

No plantio da área de queima (PAQ) foram identificados cerca de oito grupos taxonômicos de invertebrados no solo, com o total de 39 indivíduos, tais como os Hymenópteros (família Formicideae) com 25 indivíduos, correspondentes a $64 \%$ da população total, seguido de cinco Dipluros e de nove indivíduos distribuídos da seguinte forma: três Coleópteros, dois indivíduos nãoidentificados, e um indivíduo para cada seguinte grupo: Thysanóptero, Chilópodo, Proturo, e Araneae (Tabela 2).

Tabela 2 - Distribuição populacional de oito amostras numa área de Plantio de Área Queimada (PAQ), de Cana-de-açúcar (Sacharum officinalis spp.), no ecossistema hipo-edáfico com oito grupos taxonômicos constituídos de 39 indivíduos.

\begin{tabular}{|l|c|c|c|c|c|c|c|c|c|}
\multicolumn{1}{r}{ Ordens taxonômicas } & \multicolumn{9}{c}{ Amostras } \\
\hline Hymenóptero(formicidae) & 1 & 2 & 3 & 4 & 5 & 6 & 7 & 8 & total \\
\hline Coleóptero & 17 & - & 1 & 1 & - & - & - & 6 & 25 \\
\hline Araneae & 1 & 1 & - & - & - & - & 1 & - & 3 \\
\hline Dipluro & - & - & - & - & - & - & - & 1 & 1 \\
\hline Proturo & 1 & - & - & - & - & 2 & - & 2 & 5 \\
\hline ENI & - & 1 & - & - & - & - & - & - & 1 \\
\hline Total & 1 & 1 & - & - & - & - & - & 2 & 4 \\
\hline
\end{tabular}

ENI:Espécie não identificada.

Neste ecossistema observou-se uma elevada dominância de dois grupos taxonômicos com a presença de $75 \%$ de Hymenópteros e Dipluros na totalidade amostral, sendo identificados em somente três amostras. Indicando assim, perturbação ecológica ocasionada pela intervenção produtiva, que foi caracterizada pela ação destrutiva da queima, responsável pelo incremento em biodiversidade de dominância da comunidade destes Artrópodos edáficos. A presença de uma ordem a mais relativa ao $P M$, e de uma população quase que o dobro no PAQ indica que a queima apesar de nociva ao canavial é menos impactante que os efeitos verificados no PM. 


\subsubsection{PLANTIO NOVO SEM COLHEITA}

Na área do Plantio Novo Sem Colheita (PNSC) foram identificados no solo somente dois grupos taxonômicos da ordem Hymenoptera, constituídos de 4 indivíduos da família
Formicideae e um indivíduo da família Araneae, totalizando cinco indivíduos (Tabela 3).

Tabela 3 - Distribuição populacional de oito amostras dos dois grupos taxonômicos frequentes numa área de Plantio Novo Sem Colheita (PNSC), de Cana-de-açúcar (Sacharum officinalis spp.), no ecossistema hipo-edáfico com cinco indivíduos.

\begin{tabular}{|c|c|c|c|c|c|c|c|c|c|}
\hline \multirow{2}{*}{ Ordens taxonômicas } & \multicolumn{9}{|c|}{ Amostras } \\
\hline & 1 & 2 & 3 & 4 & 5 & 6 & 7 & 8 & total \\
\hline Hymenóptero(formicidae) & - & 2 & - & 2 & - & - & - & - & 4 \\
\hline Araneae & - & - & - & - & - & - & - & 1 & 1 \\
\hline Total & - & 2 & - & 2 & - & - & - & 1 & 5 \\
\hline
\end{tabular}

ENI:Espécie não identificada

O maior grau de impacto em um sistema produtivo foi verificado para esse sistema de cultivo da cana-de-açúcar, o PNSC, onde ocorrem condições muito impactantes, definida pela retirada ou a exportação total da biomassa do canavial, causando um desequilíbrio ecológico sem precedentes, de natureza biológica. Gerou-se uma condição ecológica de subtração drástica da biodiversidade e da sua abundância populacional, o que resultou na maior dominância da biodiversidade em relação aos outros dois sistemas de plantios, com características mais drásticas de perturbação ecológica que os outros dois sistemas de plantios. Este sistema de plantio causa inclusive desestruturação e desarranjo das partículas do solo, levando à perda de habitat dos animais e da biota como um todo devido ao efeito da desestruturação da porção superior do solo, local de abrigo da maior parte da biota do solo, principalmente, dos primeiros 30 centímetros de profundidade.

\subsection{AVALIAÇÃO DOS GRUPOS TAXONÔMICOS NO ECOSSISTEMA SERRAPILHEIRA}

Nas áreas de plantio mecanizado (PM) e de plantio na área de queima (PAQ) e de plantio novo sem colheita (PNSC) foram registrados 15 grupos de invertebrados -Artrópodos do solo, na região acima do solo ou do ecossistema hipo-edáfico, denominada de serapilheira sendo constituída de resíduos de folhas e de restolhos em geral da cana-deaçúcar, depositados na superfície do solo de plantio, onde foram identificados 15 grupos de Artrópodos: Araneae, Ácarineae, Colêmbolo, Dipluro, Symphila, Diplópodo, Chilópodo, Thysanóptero, Proturo, Hymenóptero (família Formicideae), Blattodeo, Díptero, Coleóptero, Larvas de Coleóptero e de Lepidóptero.

\subsubsection{PLANTIO MECANIZADO}

Para a área do Plantio Mecanizado (PM),foram registrados alguns invertebrados na região acima da superfície do solo, denominada de Serrapilheira, tendo como representantes dos seguintes 12 grupos taxonômicos de Artrópodos, constituídos de 177 indivíduos encontrados de: Colêmbolo, Hymenóptero (Formicidae), Blattodeo, Díptero, Coleóptero, Larva de Coleóptero, Araneae, Dipluro, Simphyla, Diplópodo, Proturo, Acarineae e de uma ordem não identificada, sendo que o representante mais abundante foi 0 do Colêmbolo com 132 indivíduos equivalentes a quase $75 \%$ da população total, seguido de 18 indivíduos pertencentes ao grupo das araneaes- cerca de $10,2 \%$ da população total e do restante(dos demais 10 grupos taxonômicos), constituídos por 14,8 \% da população amostral constituídos por cerca de 27 indivíduos (Tabela 4). 
Tabela 4 - Distribuição populacional de oito amostras constituídas de 12 grupos taxonômicos numa área de Plantio Mecanizado (PM), de Cana-de-açúcar (Sacharum officinalis spp.), no ecossistema Serrapilheira com 177 indivíduos.

\begin{tabular}{|l|c|c|c|c|c|c|c|c|c|}
\multicolumn{1}{c}{ Ordens taxonômicas } & \multicolumn{9}{c}{ Amostras } \\
\hline Colêmbolo & 1 & 2 & 3 & 4 & 5 & 6 & 7 & total \\
\hline Hymenóptero(formicidae) & 26 & 6 & 0 & 19 & 19 & 33 & 21 & 8 & 132 \\
\hline Blattodeo & 2 & - & - & 1 & - & 2 & 2 & - & 7 \\
\hline Díptero & 1 & - & - & - & - & - & - & - & 1 \\
\hline Coleóptero & - & 1 & - & - & - & - & - & - & 1 \\
\hline Larva de Coleóptero & 1 & - & - & - & - & - & 1 & 1 & 3 \\
\hline Araneae & - & - & - & - & - & - & 1 & - & 1 \\
\hline Dipluro & 1 & 6 & - & 1 & 3 & 5 & 1 & 1 & 18 \\
\hline Symphila & 1 & - & - & - & - & - & - & - & 1 \\
\hline Diplópodo & 1 & - & - & 2 & 2 & - & 1 & 1 & 7 \\
\hline ENI & - & - & 1 & - & - & - & - & - & 1 \\
\hline Ácaro & - & 1 & - & - & 1 & 1 & - & - & 3 \\
\hline Total & - & - & - & - & - & 1 & 1 & - & 2 \\
\hline
\end{tabular}

ENI:Espécie não identificada

A elevada população de Colêmbolos verificada na área de PM, em área de Serrapilheira foi em torno de $75 \%$ da população total (177 indivíduos), em conjunto com o segundo grupo taxonômico mais dominante, constituído pelo grupo das Araneae, o qual representa 10\% da população total do PM, identifica da mesma forma que o verificado no PM, em área de solo (hipo-edáfica), uma elevada dominância, advinda da mesma perturbação ambiental do PM na área hipoedáfica, só que destacada pela presença de Colêmbolos, o que indica a ação de uma atividade restauradora, de reorganização do ecossistema através da formação de Húmus proporcionada por esses insetos na área de plantio em consideração.

\subsubsection{PLANTIO NA ÁREA DE QUEIMA}

No plantio de área de queima (PAQ) foram registrados alguns invertebrados na serrapilheira, tendo como representantes 11 grupos taxonômicos constituídos de 70 indivíduos pertencentes aos Colêmbolo, Hymenóptero (Formicidae), Blattodeo, Díptero, Coleóptero, Araneae, Dipluro, Simphyla, Larva de Lepidóptero, Chilópodo e uma larva de uma ordem não identificada. $\mathrm{O}$ representante mais abundante foi 0 do Hymenóptero (Formicideae) com 22 indivíduos perfazendo $31,5 \%$ da população total, seguido de Araneae com 14 indivíduos equivalentes a $20 \%$ da população total, seguido de 13 indivíduos pertencentes a ordem dos Coleópteros com 18,5\% com cerca dos restantes $30 \%$ da população total, constituídos pelos oito grupos restantes (Tabela 5). 
Tabela 5 - Distribuição populacional de oito amostras num dos grupos taxonômicos numa área de Plantio de Área Queimada (PAQ), de Cana-de-açúcar (Sacharum officinalis spp.), no ecossistema Serrapilheira com 70 indivíduos.

\begin{tabular}{|l|c|c|c|c|c|c|c|c|c|}
\multicolumn{1}{c}{ Ordens taxonômicas } & 1 & 2 & 3 & 4 & 5 & 6 & 7 & \multicolumn{2}{c|}{ total } \\
\hline Colêmbolo & - & - & 1 & - & - & - & - & 1 & 2 \\
\hline Hymenóptero(formicidae) & 5 & 3 & 7 & 4 & - & - & - & 3 & 22 \\
\hline Blattodeo & - & 1 & - & - & - & - & - & - & 1 \\
\hline Díptero & - & 1 & 1 & 2 & - & - & - & - & 4 \\
\hline Coleóptero & 1 & 4 & 4 & 3 & - & 1 & - & - & 13 \\
\hline Araneae & 3 & 2 & 2 & 4 & 1 & 1 & - & 1 & 14 \\
\hline Dipluro & - & - & - & - & - & - & - & 1 & 1 \\
\hline Symphila & - & 2 & - & - & - & - & - & - & 2 \\
\hline ENI & 2 & 4 & - & 1 & 1 & 1 & - & 2 & 11 \\
\hline Total & 11 & 17 & 15 & 14 & 2 & 3 & 0 & 8 & 70 \\
\hline
\end{tabular}

- $\quad$ Amostra 4, o ENI, constitui de uma larva não identificada; Amostra 5 e 6, o ENI, constitui de uma Larva de Lepidóptero, também não identificada; Amostra 8, o ENI, constitui de: um Chilópodo e de uma Larva de Lepidóptero.

No plantio da área de queima (PAQ), na serrapilheira, observou-se a menor dominância de biodiversidade. Este fato pode ser atribuído pelo benefício da queima proporcionando ao aparecimento de alguns grupos taxonômicos relativo à sua abundância proporcional e de sua distribuição populacional, de forma empírica através dos números distribuídos de forma mais uniforme (Tabela 5) do que no PAQ-Solo (Tabela 2). Dessa forma a queima, mesmo que parcial, na serapilheira do PAQ proporcionou maior heterogeneidade $\mathrm{e}$ uniformidade na constituição de sua biodiversidade, proporcionando um "incentivo ecológico" à restauração da atividade ecológica do solo, levando ao início de uma recuperação biótica do ecossistema e o incentivo adicional para a recuperação da porção física e química do solo (porção abiótica do ecossistema).

\subsubsection{PLANTIO NOVO SEM COLHEITA}

Nesta área em avaliação não houve a presença de serrapilheira.

\section{3 ÍNDICES DE DIVERSIDADE DE ESPÉCIES NOS ECOSSISTEMAS HIPO-EDÁFICO E SERRAPILHEIRA}

\subsection{1 ÍNDICE DE MARGALEF NO ECOSSISTEMA HIPO-EDÁFICO}

O índice de Margalef mostrou resultados com uma diferença de pouco menos de $10 \%$ de variação entre os valores da área de plantio mecanizado (PM) com a área de plantio na área de queima (PAQ), para uma profundidade de até $10 \mathrm{~cm}$ no solo. Uma variação de quase 300\% ocorreu entre estas duas áreas quando comparadas com a área do plantio novo sem colheita (PNSC) (Tabela $6)$.

\subsection{2 ÍNDICE DE MARGALEF NO ECOSSISTEMA SERRAPILHEIRA}

O índice de Margalef mostrou resultados similares com uma diferença significativa de pouco menos de $11,24 \%$ de variação entre os valores da área de plantio mecanizado (PM) com a área de plantio na área de queima (PAQ), valor de $10 \%$ sendo quase igual ao do ecossistema hipo-edáfico. Nenhuma variação ocorreu entre estas duas áreas mencionadas quando comparadas com a área do plantio novo sem colheita, devido à ausência de serrapilheira nessa área. 
Tabela 6 - Valores do índice de Margalef (Mg),da população (N),e do número de espécies (S), para 3 áreas de plantio de cana-de-açúcar, no sistema hipo-edáfico e na Serrapilheira.

\begin{tabular}{|c|cl|cc|cc|}
\multicolumn{4}{c}{ Hip PNSC Serrap } & Hip (PM) & Serrap & \multicolumn{2}{c|}{ Hipoedf (PAQ) } \\
Serrap \\
\hline N & 5 & 0 & 22 & 177 & 39 & 70 \\
\hline S & 2 & 0 & 7 & 9 & 8 & 9 \\
\hline Mg & 1,43 & 0 & 4 & 4,89 & 4,4 & 4,34 \\
\hline
\end{tabular}

Hip: Sistema Hipoedáfico; Serrap: Serrapilheira; PNSC: Plantio Novo Sem Colheita; PM: Plantio Mecanizado; PAQ: Plantio em Área de Queima.

Observa-se menos contraste entre as porções taxonômicas para os sistemas de cultivo de cana-de-açúcar, implicando em menores valores deste índice, indicando portanto uma maior estabilidade do ecossistema, sendo a recíproca verdadeira e associada a uma maior estabilidade.

Sendo assim, foi o PM que apresentou o menor valor deste índice no sistema hipoedáfico, o que indica uma menor perturbação ecológica no ecossistema que empregou este tipo de plantio, enquanto o PAQ neste mesmo sistema com o maior valor indica apresentar uma menor estabilidade; já na Serrapilheira o $P A Q$ de menor valor do que o do PM, indica apresentar uma maior estabilidade do que este último.

Verificou-se no sistema hipo-edáfico (o solo propriamente dito), que o índice de Margalef, foi satisfatório em explicar a biodiversidade taxonômica da fauna edáfica constituída de alguns representantes dos Artrópodos da fauna, entre o plantio mecanizado (PM), e o plantio na área de queima (PAQ). Um terceiro plantio, o plantio novo sem colheita (PNSC), houve uma ordem crescente no valor do índice de Margalef, com o significado de que os maiores valores apresentaram maior biodiversidade, numa área mais impactada e portanto indicando em apresentar maiores níveis de recuperação demonstrada no aspecto quantitativo, relativo a uma maior população de Artrópodos edáficos na dependência diretamente proporcional quanto ao crescimento dos valores mostrados por este índice. Dessa forma a área do $P A Q$ comparativa à do PM, indica através desse índice, uma maior intervenção destrutiva ocasionada pelos efeitos deste sistema de cultivo, e que de forma inversa à estas considerações, foram dadas para as condições da serrapilheira, sendo o PAQ, o sistema que apresentou a maior estabilidade em razão da distribuição de sua abundância com menos diferenças entre as abundâncias proporcionais ou populações de seus grupos (ordens) taxonômicos do que estes valores quando observados no PM.

No plantio na área queimada no sistema hipoedáfico foi identificado uma maior perturbação ou impacto ecológico, reconhecida de forma tradicional pelas comunidades humanas. O ordenamento de valores crescentes do índice de Margalef foi indicado na razão proporcional ao potencial de impacto ou do estresse ocorrente como sendo o fator responsável em identificar maior biodiversidade de Margalef para o PAQ, o que seria condizente com um maior grau de perturbação ocasionado por uma perda ou redução da estabilidade ecossistêmica, ocasionada pelo fogo.

Porém os valores dados pelo índice de Margalef, na área da serrapilheira mostraram justamente o inverso, isto é, registrou-se uma menor biodiversidade de Margalef para o $P A Q$ do que no PM o que assegura um maior nível de estabilidade para o PAQ.

O grau de Importância dos grupos taxonômicos, pode ser compreendido através das distribuições (em porcentagem) da abundância proporcional no ecossistema hipo-edáfico em valores decimais de três grupos taxonômicos avaliados em três tipos de plantio de cana-de-açúcar. Sendo o PM para o grau de dominância assinalado para a $1^{\text {a }}$ ordem, constituído por $50 \%$ da população de Diplópodos, $18 \%$ de Aranhas ( $2^{\mathrm{a}}$ ordem) e de $32 \%$ para outros cinco grupos taxonômicos (residual), também o PAQ, que é constituído de 64\% de Hymenópteros (Formicidae) para $1^{a}$ ordem, $13 \%$ de Dipluros ( $2^{\mathrm{a}}$ ordem) e de $23 \%$ para outros seis grupos taxonômicos (residual), e completando com o PNSC, constituído de somente dois grupos taxonômicos com somente cinco indivíduos, constituído de um maior valor tanto para a $1^{\text {a }}$ ordem quanto para a segunda, relativo ao seu grau de Importância (Tabela 7 ). 
Tabela 7 - Valores porcentuais do Grau de Importância dos Grupos taxonômicos no ecossistema hipo-edáfico, considerados três agrupamentos taxonômicos para primeira e segunda ordem e o residual, considerados para três sistemas de cultivos de canavial.

\begin{tabular}{|c|c|c|c|}
\hline Grau de importância & PNSC $(\mathrm{I} \cdot \mathrm{Mg}=0,8)$ & $\mathrm{PM}(\mathrm{i} \cdot \mathrm{Mg}=4)$ & $\mathrm{PAQ}(\mathrm{i} \cdot \mathrm{Mg}=4,4)$ \\
\hline $1^{\mathrm{a}}$ ordem & 0,80 & 0,50 & 0,64 \\
\hline $2^{\mathrm{a}}$ ordem & 0,20 & 0,18 & 0,13 \\
\hline Residual & 0,00 & 0,32 & 0,23 \\
\hline
\end{tabular}

I.Mg: Índice de Margalef; PNSC: Plantio Novo Sem Colheita; PM: Plantio Mecanizado; PAQ: Plantio em Área de Queima.

Assim o PM do Sistema hipo-edáfico apresentou menor variação entre seus grupos taxonômicos quando comparado com o PAQ, estabelecendo uma relação inversa para o valor do índice de Margalef com o grau de estabilidade da porção biótica do ecossistema, indicando maior estabilidade para este (PM), de menor valor (4), comparativo ao PAQ para este índice, sendo a recíproca verdadeira para o PAQ (Tabela 7).

O Grau de Dominância no ecossistema serrapilheira em valores decimais considerados para três grupos taxonômicos também pode ser avaliados em dois tipos de plantio de cana-de-açúcar. Sendo O PM considerado para o grau de dominância para a $1^{a}$ ordem, constituído por aproximadamente de $75 \%$ da população de Colêmbolos, 10,2\% de Aranhas ( $2^{\mathrm{a}}$ ordem), e 14,8\% para outros 10 grupos taxonômicos (residual), sendo que 8\% para dois grupos incluídos aí no grupo residual constituídos de Symphila e de Hymenópteros; e o PAQ, que foi constituído de $31,4 \%$ de Hymenópteros (Formicidae) para $1^{\mathrm{a}}$ ordem, $20 \%$ de Araneae ( $2^{\mathrm{a}}$ ordem), e $48,6 \%$ para outros seis grupos taxonômicos (residual), sendo que 18,6\% constituído da Ordem Coleóptero (Tabela 8); por não existir serrrapilheira no PNSC, não houve nenhuma avaliação quanto ao grau de dominância neste plantio.

Tabela 8 - Valores porcentuais do Grau de Dominância dos Grupos taxonômicos no ecossistema da Serrapilheira, considerados três agrupamentos taxonômicos para primeira e segunda ordem e o residual, em dois sistemas de Plantios no canavial.

\begin{tabular}{|c|c|c|}
\hline Grau de Importância & PM (i.Mg = 4,84) & PAQ (i.Mg = 4,34) \\
\hline $1^{\text {a }}$ ordem & 0,75 & 0,31 \\
\hline $2^{\mathrm{a}}$ ordem & 0,10 & 0,20 \\
\hline Residual & 0,15 & 0,49 \\
\hline
\end{tabular}

I.Mg:Índice de Margalef; PM: Plantio Mecanizado; PAQ: Plantio em Área de Queima.

Assim O PAQ da serrapilheira apresentou menor variação entre seus grupos taxonômicos quando comparado com o PM, estabelecendo uma relação inversa para o valor do índice de Margalef com o grau de estabilidade da porção biótica do ecossistema, indicando maior estabilidade para o $P A Q$, de menor valor para este índice $(4,34)$, sendo a recíproca verdadeira ocorrendo com o PM (Tabela 8).

\subsection{3 ÍNDICE DE DOMINÂNCIA DE SIMPSON NOS ECOSSISTEMAS HIPO-EDÁFICO E SERRAPILHEIRA}

A necessidade de maior compreensão do funcionamento de um ecossistema, é advinda do resultado da análise da coleta de dados de maior quantidade de fatores bio- ecológicos existentes, enfatizando como base de estudo os principais fatores determinantes ao entendimento da totalidade dos fatores ecológicos.

Dessa forma, a inclusão de uma crescente averiguação dos ecossistemas através de diferentes índices que assinalam outras propriedades inerentes ao funcionamento e compreensão dos ecossistemas baseadas na presença da biodiversidade, resultará no objetivo almejado de melhor qualidade de informação e na determinação do grau de qualidade dos ecossistemas em estudo, o que pode ser mesclado com a informação do grau de estabilidade dos mesmos.

Então incluiu-se neste estudo a discussão da avaliação do índice de dominância de Simpson, como alternativa de uma complementariedade ou até como possível 
substituição do índice de Margalef. Porém não deverá levar em consideração o descarte deste índice, mesmo que o índice de Simpson predecessor em avaliação resulte em melhores acurácias informativas baseadas na Teoria da Informação. Será portanto, melhor associar os índices de menores graus de acurácia com os de maiores, a fim de maior entendimento do funcionamento dos ecossistemas baseado nas propriedades inerentes à biodiversidade, tais quais a dominância das espécies.

\subsection{4 ÍNDICE DE DOMINÂNCIA DE SIMPSON NO SISTEMA HIPO-EDÁFICO:}

A área de menor dominância relativa observada no PM correspondeu de forma recíproca a de maior Uniformidade, com menor variação entre os valores do grau de importância, ou do percentual relativo ou proporcional, entre a população de cada grupo taxonômico com a população total. Sendo que para o $P A Q$, isso ocorreu de forma inversa, com um maior grau de dominância observado neste plantio, mas não maior como o constatado no PNSC, constituído do menor grau de uniformidade empírica (Tabela 7).

Utilizando então o índice de diversidade de Simpson, constatou-se a mesma tendência encontrada no grau de dominância empírico (Tabela 7), onde os valores crescentes deram-se na seguinte ordem: PM, seguido do PAQ e este do PNSC (Tabela 8).
Dessa forma pôde-se constatar maior discrepância para este índice, para os plantios, do que os averiguados pelo índice de Margalef, o que é geralmente desejável, para se atribuir critérios de melhor escolha do emprego de um índice para obter melhores resultados na avaliação da biodiversidade.

Observou-se que o grau de dominância empírico de ordem "residual" (Tabela 7), estabeleceu um ordenamento recíproco, conforme a tendência normal estabelecida pelo índice de Simpson (Tabela 8), e pela dominância empírica de $1^{\text {a }}$ ordem (Tabela 7), mas de forma parcial pela Dominância de $2^{a}$ ordem, estabelecendo-se de forma completamente invertida na ordem ou termo Residual (Tabela 7).

De forma inversa ao ocorrido no ecossistema serrapilheira, verificou-se que o plantio de menor dominância relativa observada no sistema hipo-edáfico, no PM, correspondeu ao plantio de maior uniformidade, indicada por menor variação entre os valores do grau de dominância, ou do percentual relativo ou proporcional, entre a população de cada grupo taxonômico com a população total, sendo que para o PAQ, isso ocorrereu de forma inversa, com maior grau de dominância observado neste plantio (Tabela 9 ).

Utilizando então o índice de diversidade de Simpson, constatou-se a tendência inversa encontrada no grau de dominância empírica (Tabela 8), em que o valor do PM, foi seguido pelo do PAQ (Tabela 9).

Tabela 9 - Índices de Margalef e de dominância de Simpson(Ds), dados comparativos entre três áreas de plantios de cana-de-acúcar no sistema hipoedáfico.

\begin{tabular}{|c|c|c|c|}
\hline & PNSC & PM & PAQ \\
\hline $\mathrm{N}$ & 5 & 22 & 39 \\
\hline $\mathrm{S}$ & 2 & 7 & 8 \\
\hline $\mathrm{Mg}$ & 1,43 & 4 & 4,40 \\
\hline $\mathrm{Ds}$ & 0,68 & 0,28 & 0,44 \\
\hline
\end{tabular}

N, é a população amostral de cada plantio, e S, o número total de Grupos taxonômicos, ou de Ordens destes invertebrados. Mg, é o Índice de Margalef e Ds, o Índice de Simpson. PNSC: Plantio Novo Sem Colheita; PM:

Plantio Mecanizado; PAQ: Plantio em Área de Queima.

\subsection{5 ÍNDICE DE DOMINÂNCIA DE SIMPSON NO ECOSSISTEMA SERRAPILHEIRA}

Conforme verificado anteriormente, no início dos Resultados e Discussão, do ecossistema hipo-edáfico, o índice de dominância de Simpson, poderá ser utilizado como alternativa e pretexto de uma complementariedade ou até mesmo como substituto do índice de Margalef.
Porém será preferível não descartar este índice, mesmo que o seu predecessor em avaliação obtenha melhores acurácias informativas baseadas na Teoria da Informação. Será portanto, melhor aceitar o índice de menores graus de acurácia, conjuntamente com os de maiores, a fim de que possamos entender o funcionamento dos ecossistemas baseado nestas propriedades 
inerentes à biodiversidade, tais quais a Dominância, aqui em discussão.

De forma inversa ao ocorrido no ecossistema hipo-edáfico, verificou-se que a área de menor dominância relativa à observada no $P A Q$, da serrapilheira, correspondeu de forma recíproca a de maior uniformidade, indicada através de menor variação entre os valores do grau de dominância, ou do percentual relativo ou proporcional, entre a população de cada grupo taxonômico com a população total, sendo que para o $\mathrm{PM}$, isso ocorrerá de forma inversa, com um maior grau de dominância observado neste plantio, constituído do modo inverso de menor grau de uniformidade empírica constatado (Tabela 10).

Utilizando então o índice de diversidade de Simpson, constatou-se a mesma tendência verificada no grau de dominância empírico (Tabela 8), em que o valor do PM, foi seguido pelo do PAQ (Tabela 10).

Tabela 10 - Índices de Margalef e de Dominância de Simpson dados comparativamente para 2 áreas de plantios de Cana-de-Açúcar na Serrapilheira.

\begin{tabular}{|c|c|c|}
\hline & PM & PAQ \\
\hline $\mathrm{N}$ & 177 & 70 \\
\hline $\mathrm{Mg}$ & 12 & 9 \\
\hline $\mathrm{Ds}$ & 4,89 & 4,34 \\
\hline
\end{tabular}

N é a população amostral de cada plantio, e S, o número total de Grupos taxonômicos, ou de Ordens destes invertebrados. Mg é o Índice de Margalef e Ds, o Índice de Simpson; PM: Plantio Mecanizado; PAQ: Plantio em Área de Queima.

Da mesma forma como ocorrida no ecossistema hipo-edáfico, pôde-se constatar maior discrepância para este índice, quando comparado com índice de Margalef, no ecossistema serrapilheira, o que é geralmente desejável, para se atribuir critérios de melhor escolha do emprego de um índice, com melhores resultados na avaliação da biodiversidade. Observou-se que o grau de dominância empírico de ordem "residual" (Tabela 8), estabeleceu um ordenamento recíproco, conforme também a tendência normal estabelecida pelo índice de Simpson (Tabela 9), e também pela dominância empírica de $1^{\text {a }}$ ordem (Tabela 8), mas de forma parcial pela dominância de $2^{\mathrm{a}}$ ordem, estabelecendo-se de forma completamente invertida na ordem ou termo residual (Tabela 8).

\section{CONCLUSÕES}

O Índice de Margalef não foi um bom descritor de biodiversidade quando considerado somente com os parâmetros do número de espécies (ou de grupos taxonômicos) e da população total do sistema de plantio. Este índice foi eficaz em considerar valores proporcionais para a abundância proporcional, em que as menores diferenças entre os grupos que compunham essa abundância para cada sistema de plantio, indicavam menores valores verificados para este índice, sendo a recíproca verdadeira.

A distribuição populacional assinalada pela distribuição da abundância proporcional dos grupos taxonômicos em cada sistema de plantio de cana-de-açúcar, indica que as menores diferenças entre as abundâncias consideradas para cada sistema de plantio, indica maior uniformidade acompanhada da menor dominância e vice-versa, com o significado de um plantio com maior grau de perturbação.

Para o sistema hipo-edáfico, O PM, apresentou os menores valores para os índices de Margalef e o de dominância de Simpson, o PAQ com os maiores valores, e o PNSC com valores altos somente para o índice de Simpson. Este fato se caracterizouse pelas diferentes condições edáficas impactadas. Sendo assim o PM apresenta o melhor grau de manutenção ou de estabilidade comparativamente ao PAQ, e o PNSC coloca-se em último lugar.

Para o sistema de serrapilheira, o PAQ foi o plantio que apresentou os menores valores para os índices de Margalef e o de dominância de Simpson, sendo o PM, com os maiores valores. Sendo assim, O PAQ apresenta o melhor grau de manutenção ou de estabilidade comparativamente ao PM, o que pode implicar em novas e importantes considerações de medidas para o manejo e 
açúcar.

\section{REFERÊNCIAS}

[1] Barret, G. W., Odum, E. P. Fundamentos de Ecologia. Ed. Cengage Learning. São Paulo. 2008. 628p.

[2] Becker, Bigarella e Passos: Estrutura e Origem das Paisagens Tropicais e Subtropicais vol2. Ed.da UFSC. Florianópolis. 1996. 453 p.

[3] Brussaard, I., Moreira, F. M. S., Siqueira, J.O. Biodiversidade do Solo em Ecossistemas Brasileiros. Ed UFLA. Lavras, 2008. 678p.

[4] Beckinser, G. Fauna in soil ecosystems. Marcel Deckker, 1997. 414p.

[5] Collins,H.P., Robertson,G.P.,Klug,M.J. The significance and regulation of soil biodiversity. Kluwer Academic Publishers. Dordrecht, 1995. 300p.

[6] Lavelle, P. Ecological challenges for soil science. Soil Science, v. 165, n. 1 p. 73-86, 2000.

[7] Magurran, A. Ecological diversity and its mesasurement. Croom Helm London, 1988. 204 p.

[8] Mason, C.F. Decomposição, coleção temas de biologia. EPU/Edusp: São Paulo, v.18, 1980. $76 \mathrm{p}$.

[9] Mattson, W. J.(ed.). The Role of Arthropods in Forest Ecosystems-Proceedings in

Life Sciences; ED.: Spring Verlag. New York, 1977.104 pp

[10] Moreira, F. M. S.; Siqueira, J.O., Microbiologia e Bioquímica do solo. Lavras: Ufla, 2009.626 p.

[11] Perrings, C.;Mäler K.; Folke C.; Holling, C.S.;Jansson, B. Biodiversity loss- economic and ecological issues. Cambridge University Press. New York 1997. 347 p.

[12] Pielou,E.C. Population and community ecology. Principles and Methods. 4 ed. Gordon \& Breach, New York, 1983.424p.

[13] 1984. 276p. Silva, O. Manual Prático e Técnico de Agricultura. Campinas. Editora Cartgraf limitada. 1982. 540 p.

[14] Terborgh, J. Maintenance of diversity in tropical forests. Biotropica 24: 283-292, 1992.

[15] Vargas, M.A.T. \& Hungria, M., eds. Biologia dos solos dos cerrados. Planaltina, Empresa Brasileira de Pesquisa Agropecuária, Centro de Pesquisa Agropecuária dos Cerrados, 1997. p.297-360. 


\section{Bapítulo 6}

\section{MUDANCAS NO USO DO SOLO, VEGETACIONAL E ESTRUTURA DA PAISAGEM NO ENTORNO DA ESTAÇÃO ECOLÓGICA DE FECHOS - MG.}

\section{Luciana Eler França}

\section{Lourdes Manresa Camargos}

\section{Luiza Cintra Fernandes}

\section{Fernando Figueiredo Goulart}

Resumo: As alterações da paisagem geradas por atividades antrópicas causam a fragmentação da vegetação natural e o isolamento de unidades de conservação, resultando em uma maior exposição e perturbações externas destes ambientes, sendo importante a avaliação desses processos. Esse trabalho teve como objetivo realizar uma análise espacial e temporal das mudanças de cobertura vegetal e tipos de uso do solo e fitofisionomias nos últimos 25 anos do entorno da Estação Ecológica de Fechos. Através de técnicas de geoprocessamento e ecologia da paisagem obteve o resultando da identificação das pressões antrópicas sobre a cobertura vegetal. Verificou-se o aumento da área urbana, fruto da expansão imobiliária, em 313\% e da área de mineração em 159\%, na região de estudo. Constatou-se uma grande pressão dessas áreas antrópicas sobre as unidades de conservação e Áreas de Preservação Permanente (APP). Considerando os resultados encontrados, conclui-se que essas técnicas permitem uma análise robusta da evolução territorial de uso do solo ao longo do tempo e possibilita que sejam realizadas diretrizes de tomadas de decisão baseadas em dinâmicas ecológicas espacialmente explícitas.

Palavras-chave: Estação Ecológica de fechos; Ecologia da Paisagem; Geoprocessamento; Planejamento; Unidades de Conservação. 


\section{INTRODUÇÃO}

A Lei 9.985, de 18 de julho de 2000, que instituiu o Sistema Nacional de Unidades de Conservação (SNUC) define a unidade de conservação, como sendo um espaço territorial e todos os recursos ambientais que compõe o mesmo, tendo como objetivo a conservação e manutenção da biodiversidade dentro do seu limite definido. Um problema relacionado com essas áreas é a manutenção da sua biodiversidade, pois a legislação atua somente no interior destas áreas e descreve somente diretrizes para minimização das pressões e alterações em relação a sua paisagem do seu entorno (COSTA, 2013). Estas alterações geram a fragmentação do ambiente, modificando extensas áreas de vegetação natural, resultando em um mosaico e isolando a unidade de conservação (FORMAN \& GORDON, 1986).

Qualquer estudo paisagístico deve compreender as relações do meio ambiente e sua dinâmica. Para isso, é necessária uma visão integrada dos fatores físicos e biológicos de sistemas naturais e suas interações com os fatores socioeconômicos e políticos (FILHO, 1998). O estudo da ecologia da paisagem é uma maneira de identificar alterações da paisagem. Trata-se de uma disciplina que propõe o estudo da estrutura, função e mudança destas regiões heterogêneas, buscando identificar padrões das alterações e estudar a dinâmica de uma região geográfica através de métricas da paisagem (MARTINS et al, 2004).

O estado de Minas Gerais possui, atualmente, 562 unidades de conservação criadas, representando uma área de 5.700.963,2 ha, equivalente apenas a 9,71\% da área total do Estado (IEF, 2017). Esse valor é extremamente baixo em relação à extensão territorial total do estado. Além disso, essas unidades de conservação, dependendo do entorno, acabam por se tornarem ilhas, pois ficam isoladas em relação à matriz da paisagem do seu entorno, perdendo a função que lhes cabem.

A Ecologia da Paisagem é uma ciência que estuda a dinâmica de uma região geográfica, definida como paisagem. Essa terminologia é caracterizada por ser uma área espacialmente heterogênea (TURNER \& GARDNER, 1990), que engloba a descrição das características estáticas e dinâmicas de uma determinada região em relação aos aspectos naturais e culturais.
O estudo das questões ambientais dentro de uma paisagem qualquer deve compreender as relações do meio ambiente e sua dinâmica. Para isso, é necessária uma visão integrada dos fatores físicos e biológicos de sistemas naturais e suas interações com os fatores socioeconômicos e políticos (FILHO, 1998). O estudo da ecologia da paisagem é uma maneira de identificar alterações da paisagem. A disciplina que propõe o estudo da estrutura, função e mudança destas regiões heterogêneas, buscando identificar padrões das alterações e estudar a dinâmica de uma região geográfica através de métricas da paisagem (MARTINS et al, 2004).

Os dados quantitativos da estrutura da paisagem são denominados como índices ou métricas da Ecologia da Paisagem. Ao quantificar a composição e configuração da paisagem, esses índices permitem a comparação entre paisagens ou entre a mesma paisagem em diferentes momentos, permitindo a identificação dos processos funcionais e dos padrões ecológicos das paisagens (LUCAS, 2011).

As informações adquiridas por esse tipo de análise podem apoiar a formulação de políticas de planejamento urbano e manutenção de recursos naturais. A caracterização de uma determinada paisagem é obtida através da quantificação de suas estruturas, possibilitando contextualizar a distribuição espacial de seus elementos e determinar as ações resultantes desse processo, que por sua vez, permitem o melhor direcionamento das ações de conservação e preservação dos recursos florestais (VIANA et. al., 1992).

Esse tipo de estudo é, portanto, imprescindível para a análise da qualidade ambiental de uma área, permitindo selecionar aquelas de interesse à manutenção biótica e assim reduzir impactos na dinâmica espacial em uma determinada região.

Diante do exposto, objetiva-se com este trabalho fazer uma análise espaço-temporal de 25 (1992, 2001, 2010 e 2017) anos do entorno da Estação Ecológica de Fechos, visando identificar pressões antrópicas na área, permitindo um melhor direcionamento das ações de conservação e preservação dos recursos florestais. 


\section{METODOLOGIA}

\section{1ÁREA DE ESTUDO}

A Estação Ecológica de Fechos localiza-se no município de Novo Lima, em Minas Gerais. O território está inserido na região do Quadrilátero Ferrífero, dentro da Área de Preservação Ambiental (APA) Sul da Região Metropolitana de Belo Horizonte (Figura 1). A área-alvo deste estudo compreende uma área de raio de $10 \mathrm{~km}$, a partir da EE de Fechos e abrange uma área total de 41.361,83 ha. A região é composta por fitofisionomias florestais (floresta estacional semi-decidual), áreas de campos rupestres, principalmente sobre litologias de canga e uma importantíssima área de Campo Ferruginoso.

Figura 1 - Localização da área de estudo

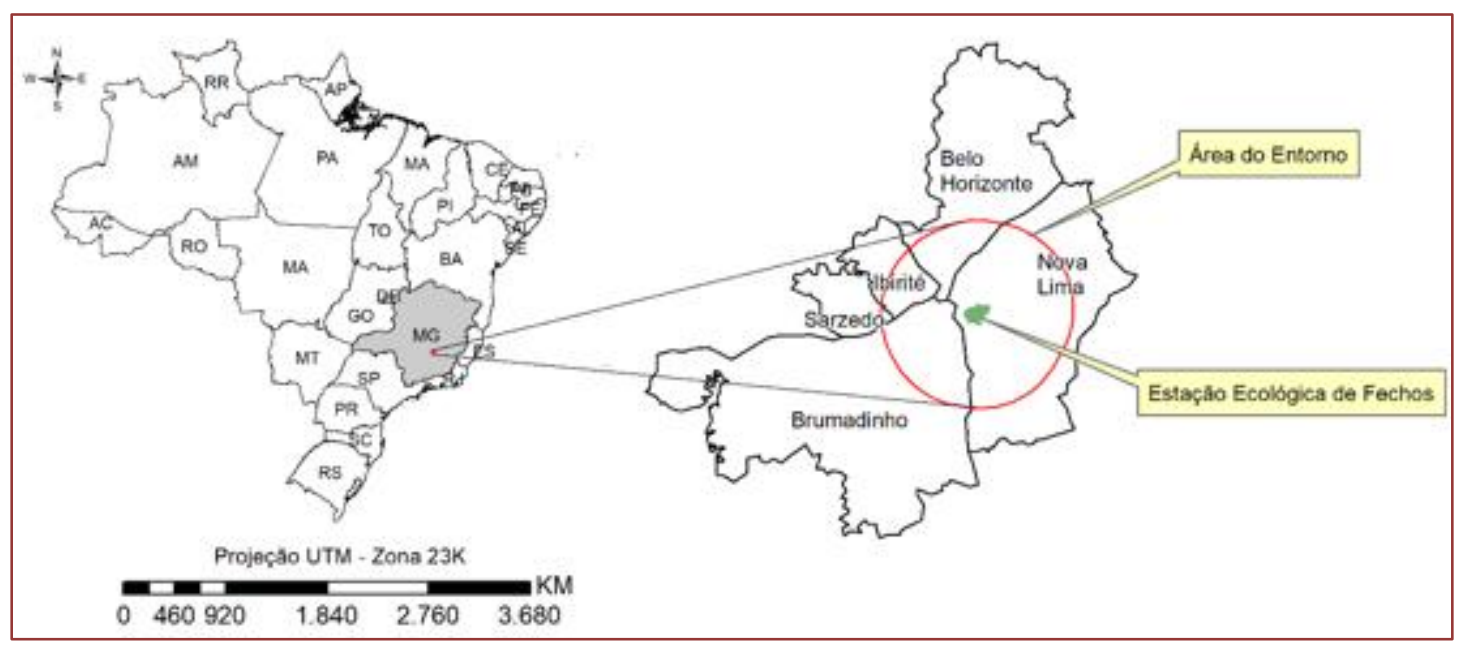

Essa unidade foi instituída pelo Decreto $n^{\circ}$ 36.073, de 27 de setembro de 1994 e teve como objetivo a proteção do manancial de água na bacia do ribeirão dos Fechos e dos ambientes naturais.

A área-alvo deste estudo compreende uma área de raio de $10 \mathrm{~km}$, a partir da $\mathrm{EE}$ de Fechos e abrange uma área total de 41.361,83 ha. Essa área foi definida de acordo com a descrição da Resolução Conama $n^{\circ} 13$, de 06 de dezembro de 1990. Esta resolução esboça que obrigatoriamente qualquer empreendimento que possa afetar a biota e encontrar-se dentro do limite de uma área de $10 \mathrm{~km}$ do entorno de unidades de conservação deverá ser licenciada pelo órgão ambiental competente (ZAÚ, 1998; BRITO, 2006). Essa área de $10 \mathrm{~km}$ é delimitada em casos de unidade de conservação que não possui a área de amortecimento definida pelo seu plano de manejo. A delimitação dessa área é considerada fundamental na manutenção da funcionalidade ecológica dos fragmentos que compõe as unidades de conservação, denominando-se assim, como zonas de uso restritivo (zona de amortecimento). Logo, para estudar o impacto da pressão antrópica sobre a unidade, o ideal é pegar a área definida como fundamental e com a existência de amparo jurídico.

\section{PROCEDIMENTOS METODOLÓGICOS}

O presente trabalho consistiu nas seguintes etapas metodológicas, presentes no fluxograma da Figura 2 e descritas em seguida: 
Figura 2 - Fluxograma da metodologia.

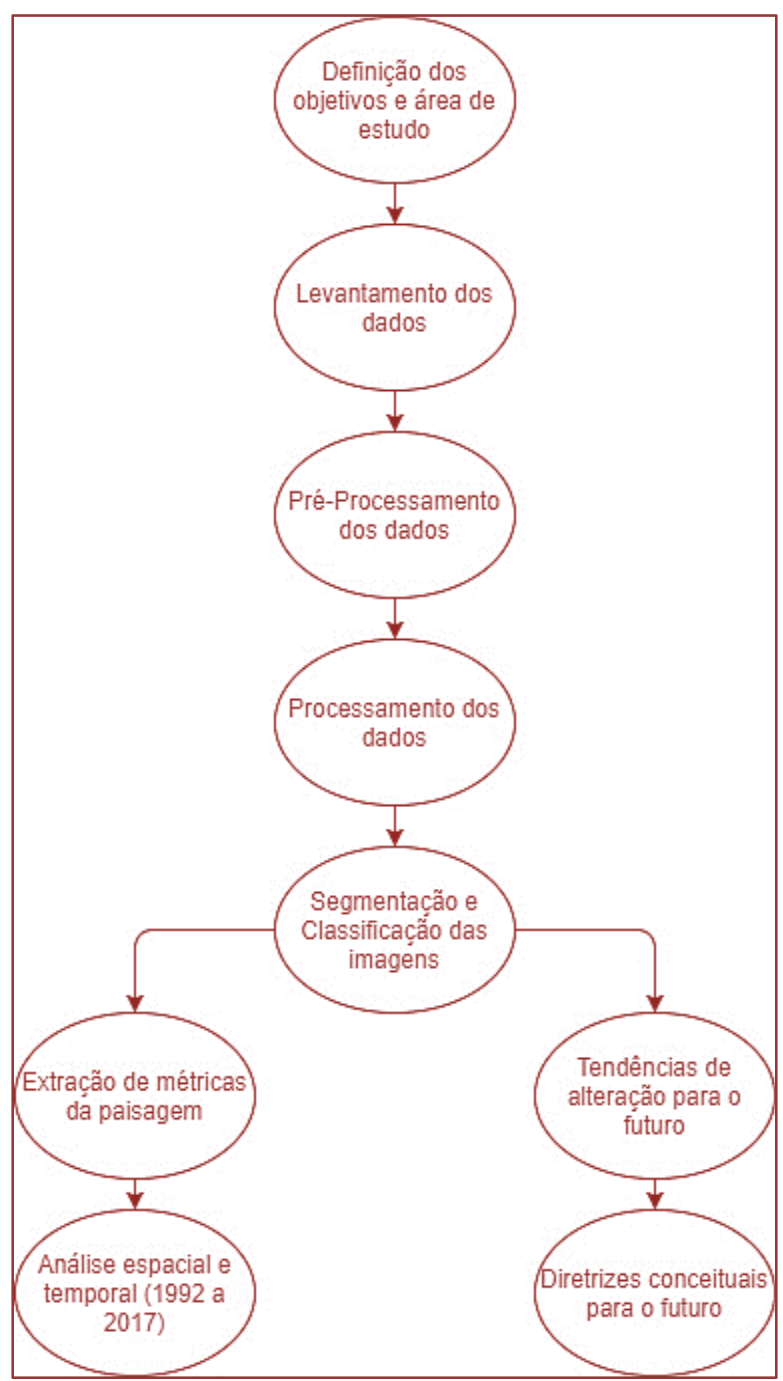

- Aquisição de imagens de satélite obtidas no Instituto Nacional de Pesquisa Espaciais - INPE para o recobrimento da área de estudo. Para isso, foram necessárias três imagens Landsat 7 - Sendor TM $(30 \mathrm{~m}$ de resolução espacial, 8 bits por pixel de resolução radiométrica) relativas às cenas 218/074 e uma imagem Landsat 8 (30m de resolução espacial, 16 bits por pixel de resolução radiométrica), relativa à cena 225/085. O satélite Landsat 7 e Landsat 8, fornecem imagens de 7 e 8 bandas espectrais, respectivamente. Contudo, no presente projeto foram utilizadas as seguintes bandas para cada imagem:

- Imagens do satélite Lansat 7 dos anos 1992, 2001 e 2010, das bandas 3 (vermelho), 4 (infravermelho próximo) e 5 (infravermelho médio);

- Imagens do satélite Lansat 8 do ano de 2017, das bandas 4 (vermelho), 5 (infravermelho próximo) e 6 (infravermelho médio).

- Pré-processamento das imagens como remoção de ruídos e aplicação de contraste de composição RGB453 (Landsat 7) e RGB564 (Landsat 8). Esta etapa e a etapa seguinte foram realizadas no software Spring 5.5.2;

- Processamento das imagens: primeiramente foi realizada a segmentação e posteriormente, foi realizada a classificação supervisionada das imagens, utilizando-se o classificador Bhattacharya. O Bhattacharya trata-se de um classificador superviosionado por regiões, que utiliza a distância Bhattacharya para medir a separabilidade estatística entre cada par de classes espectrais, sendo que a separabilidade é calculada através da distância média entre as distribuições de probabilidades de classes espectrais (Leão et al., 2007). Este 
classificador requer a obtenção de áreas de treinamento, que foram obtidas através da seleção de amostras prévias pertinentes a cada tipo de classe. A seleção de amostras de classes ocorreu por meio de interpretação visual, baseada em elementos como tonalidade/cor, forma e textura dos pixels de cada cena. A classificação foi dividida em cinco classes de uso e ocupação do solo: área urbana, área de mineração, formação campestre, formação florestal e corpos de água;

- Realização de análise temporal e espacial de fragmentação da área de estudo dos anos de 1992, 2001, 2010 e 2017. A análise ocorreu através da extração de métricas de ecologia da paisagem, a partir de categorias de área, densidade e tamanho, forma, área nuclear, proximidade e diversidade, utilizando-se os índices descritos na Tabela 1. Esta etapa foi realizada no software Arcgis 10.1, com as extensões Patch e V-Late Beta 2.0:

- Em relação à categoria Densidade e Tamanho foram analisadas as métricas: Número do Fragmento, Tamanho Médio do Fragmento e Desvio Padrão do Tamanho Médio do Fragmento (Tabela 3);

- Em relação à categoria de forma, o índice de forma foi analisado somente para a formação florestal e formação campestre, pois o seu fundamento a pressão ocasionada pelo efeito borda. Este índice analisado no formato vetorial possui a forma padrão adotada por um círculo (PIROVANI, 2010; Lucas 2011). Quanto mais próximo de 1, mais circulares são os fragmentos (FORMAN, 1995). Este índice é calculado de modo a representar a proporção perímetro/área dos fragmentos. Um fragmento com forma circular ou quadrangular, apresenta uma área interna maior e uma maior razão interior/borda, interagindo em menor intensidade com a matriz circundante e estando menos sujeito às ações do efeito de borda;

- Em relação à categoria Área Nuclear foram analisadas as métricas: Número de Áreas Centrais, Área Central Total e Índice de Área Central (Tabela 5 e Figura 6). Para o cálculo dessa categoria foi aplicado um buffer negativo de $100 \mathrm{~m}$, resultando a Área Core, que descreve a área para dentro do fragmento (SILVA e SOUZA, 2014). Em relação à categoria de Área Nuclear foi analisado somente para a formação florestal e formação campestre, pois o seu fundamento é verificar se sofreram problemas ocasionados pelo efeito borda;

- Em relação a categoria proximidade foi analisada o Índice de distância do vizinho mais próximo. Este índice descreve a distância entre os fragmentos mais próximos (CABACINHA, CASTRO e GONÇALVES, 2010);

- Em relação à categoria Diversidade foram analisadas as métricas: Proporção; Índice de Diversidade de Simpson - SDI e Índice de Equitatibilidade de Shannon (SEI) (Tabela 7). Este índice de diversidade poderá ser igual a zero, se houver apenas uma classe na paisagem e quando for maior que zero significa um maior número de tipos de classes ou distribuição proporcional de aumentos de tipos de classes (PIROVANI et al., 2015; MOREIRA, 2008). Assim, quanto maior os valores dos índices (SDI e SEI) significa maior diversidade de paisagem, refletindo com isso a uma maior riqueza e equitatibilidade (MOREIRA, 2008). Segundo Moreira (2008) o Índice de Diversidade de Simpson verifica a riqueza das classes que compõe a paisagem e o Índice de Equitatibilidade de Shannon mede a perspectiva da fragmentação e heterogeneidade da paisagem. 
Tabela 4 - Índices de ecologia de paisagem utilizados.

\begin{tabular}{|c|c|c|c|}
\hline Categoria & Métrica & Sigla & Observação \\
\hline Área & Área da Classe (ha) & CA & Área de todos os fragmentos da classe em hectares. \\
\hline \multirow{3}{*}{$\begin{array}{l}\text { Densidade e } \\
\text { Tamanho }\end{array}$} & $\begin{array}{l}\text { Número de Fragmentos } \\
\text { (Adimensional) }\end{array}$ & NP & Número de fragmentos existentes na classe. \\
\hline & $\begin{array}{l}\text { Tamanho Médio do Fragmento } \\
\text { (ha) }\end{array}$ & MPS & $\begin{array}{l}\text { Média entre as áreas em hectares de todos os } \\
\text { fragmentos da classe. }\end{array}$ \\
\hline & $\begin{array}{l}\text { Desvio Padrão do tamanho do } \\
\text { fragmento (ha) }\end{array}$ & PSSD & $\begin{array}{l}\text { A raiz quadrada do erro médio quadrático do tamanho } \\
\text { dos }\end{array}$ \\
\hline Forma & $\begin{array}{l}\text { Índice de Forma médio } \\
\text { (Adimensional) }\end{array}$ & PAFRAC & $\begin{array}{l}\text { É a média do índice SHAPE para os fragmentos da } \\
\text { classe correspondente. }\end{array}$ \\
\hline \multirow{3}{*}{ Área Nuclear } & $\begin{array}{l}\text { Número de áreas centrais } \\
\text { (admensional) }\end{array}$ & $\mathrm{NCA}$ & Número de áreas centrais de toda a classe. \\
\hline & Área Central total (ha) & TCA & Soma das áreas centrais de toda a classe em hectares. \\
\hline & Índice de área central (\%) & TCAI & $\begin{array}{l}\text { Percentagem da classe que é área central, baseado na } \\
\text { largura de borda especificada. }\end{array}$ \\
\hline Proximidade & $\begin{array}{c}\text { Distância do vizinho mais próximo } \\
(\mathrm{m})\end{array}$ & NEAR & $\begin{array}{l}\text { Distância euclidiana borda-a-borda entre o fragmento e } \\
\text { o mais próximo de mesma classe }\end{array}$ \\
\hline \multirow{2}{*}{ Diversidade } & Índice de Diversidade & SHDI & $\begin{array}{l}\text { Soma, entre todas as classes, da abundância } \\
\text { proporcional de cada classe multiplicada por aquela } \\
\text { proporção (abundância da proporção vezes o logaritmo }\end{array}$ \\
\hline & Índice de Diversidade & SIDI & $\begin{array}{l}1 \text { menos a soma, entre todas as classes, da abundância } \\
\text { proporcional de cada classe ao quadrado. }\end{array}$ \\
\hline
\end{tabular}

\section{RESULTADOS E DISCUSSÃO}

\subsection{COBERTURA VEGETAL E USO DO SOLO}

A variação da ocupação das classes de uso e cobertura da terra na área de estudo é possível ser visualizada na Figura 3 que mostra os mapas obtidos da classificação supervisionada dos anos de 1992 (A), 2001 (B), 2010 (C) e 2017 (D). As classes de cobertura vegetal e de uso do solo que foram detectadas são: Formação Campestre e Florestal, Corpos de Água, Mineração e Urbanização. 
Figura 3 - Cobertura Vegetacional e Uso do Solo de 1992 (A), 2001 (B), 2010 (C) e 2017 (D).



A classe de cobertura vegetal predominante para os anos avaliados, em questão de área, foi a Formação Campestre. Com relação ao uso do solo, a classe predominante foi Área Urbana (Tabela 5). Em termos de pressão antrópica sobre a cobertura vegetal da área de estudo, a área urbana teve um aumento de $313 \%$ e a área de mineração de 159\%. O aumento destas classes ocorreu pela expansão imobiliária e minerária nesta região, que vêm crescendo consideravelmente nos últimos anos. A classe Formação Campestre reduziu $35 \%$ e a classe Formação Florestal reduziu 11\% no intervalo de 25 anos (Tabela 5 e Figura 44). 
Figura 4 - Evolução das classes de uso e ocupação do solo ao longo dos anos

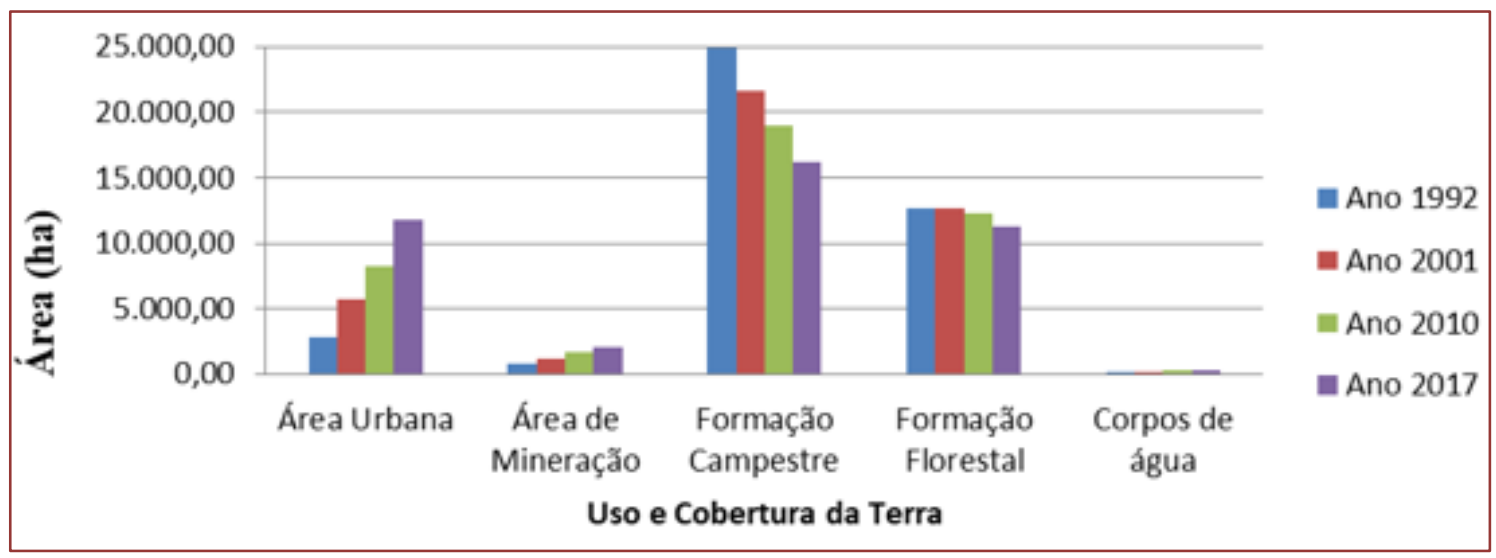

Tabela 5 - Cobertura Vegetacional e Uso do solo em 1992, 2001, 2010 e 2017

\begin{tabular}{|ccccccccc|}
\hline Ano & \multicolumn{2}{c}{1992} & \multicolumn{2}{c}{2001} & & & & \\
Tipologia & Área (ha) $\begin{array}{c}\text { Representati } \\
\text { vidade (\%) }\end{array}$ & Área (ha) & $\begin{array}{c}\text { Representati } \\
\text { vidade (\%) }\end{array}$ & Área (ha) & $\begin{array}{c}\text { Reprentati } \\
\text { vidade (\%) }\end{array}$ & $\begin{array}{c}\text { Área (ha) } \\
\text { Representati } \\
\text { vidade (\%) }\end{array}$ \\
\hline Área Urbana & $2.833,34$ & 6,85 & $5.654,82$ & 13,67 & $8.247,37$ & 19,94 & $11.711,98$ & 28,32 \\
\hline Área de Mineração & 790,71 & 1,91 & $1.196,58$ & 2,89 & $1.720,54$ & 4,16 & $2.051,89$ & 4,96 \\
\hline Campo & $24.913,94$ & 60,23 & $21.640,72$ & 52,32 & $18.905,20$ & 45,71 & $16.128,79$ & 38,99 \\
\hline Floresta & $12.625,69$ & 30,52 & $12.655,61$ & 30,60 & $12.231,23$ & 29,57 & $11.207,94$ & 27,10 \\
\hline Corpos de água & 198,15 & 0,48 & 214,13 & 0,52 & 257,49 & 0,62 & 261,20 & 0,63 \\
\hline Total & $41.361,83$ & 100,00 & $41.361,82$ & 100,00 & $41.361,84$ & 100,00 & $41.361,80$ & 100,00 \\
\hline
\end{tabular}

\section{ANÁLISE DA PAISAGEM}

\subsection{DENSIDADE E TAMANHO}

A quantidade de fragmentos de formação florestal teve uma redução de 35 fragmentos. Já o tamanho médio e do desvio padrão do tamanho dos fragmentos teve uma redução pequena, 1,93 ha e 0,82 ha, respectivamente. A quantidade de fragmentos da formação campestre teve um aumento de 64 fragmentos, com uma redução de 94 ha de tamanho médio e 1.106,27 ha do desvio padrão do tamanho do fragmento (Tabela 3 e Figura 5). Conclui-se que houve supressão vegetal das duas tipologias, sendo que a área total suprimida de formação florestal foi bem menor e pressupôs-se que esses fragmentos suprimidos foram os de pequenas áreas. Os fragmentos de formação campestre, além de sofrer uma redução da vegetação, também tiveram um aumento na fragmentação do mesmo. Conclui-se que os fragmentos florestais possuem uma legislação forte que ampara a sua manutenção, o que não ocorre para a formação campestre.

Os fragmentos de área de mineração se mantiveram e a sua área média e o desvio padrão aumentaram, portanto não houve a abertura de nova área, mas sim o crescimento das áreas existentes. Já os fragmentos de áreas urbanas tiveram um aumento de 199 fragmentos, ou seja, indica que há um grande crescimento dessa classe. Conclui-se que esse crescimento ocorreu sem planejamento urbano, pois foi detectada uma diminuição do tamanho médio de fragmentos e uma grande variabilidade de tamanho. 
Figura 5 (a): Número do Fragmento; (b): Tamanho Médio do Fragmento; (c): Desvio Padrão do Tamanho Médio do Fragmento.

(a)



(b)

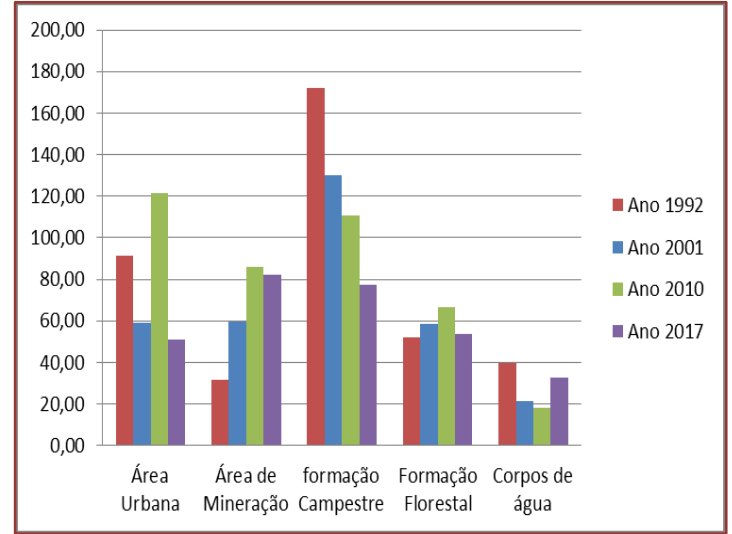

(c)



Tabela 3 - Métricas da Ecologia da Paisagem de Densidade e Tamanho para os anos 1992, 2001, 2010 e 2017.

\begin{tabular}{|c|c|c|c|c|c|c|c|c|c|c|c|}
\hline \multirow[b]{2}{*}{ Grupo } & \multirow[b]{2}{*}{ Métrica } & \multicolumn{5}{|c|}{ Ano 1992} & \multicolumn{5}{|c|}{ Ano 2001 } \\
\hline & & $\begin{array}{c}\text { Área } \\
\text { Urbana }\end{array}$ & $\begin{array}{c}\text { Área de } \\
\text { Mineração }\end{array}$ & $\begin{array}{c}\text { Formação } \\
\text { Campestre }\end{array}$ & $\begin{array}{r}\text { Formação } \\
\text { Florestal } \\
\end{array}$ & $\begin{array}{c}\text { Corpos de } \\
\text { água }\end{array}$ & $\begin{array}{c}\text { Área } \\
\text { Urbana }\end{array}$ & $\begin{array}{c}\text { Área de } \\
\text { Mineração }\end{array}$ & $\begin{array}{c}\text { Formação } \\
\text { Campestre }\end{array}$ & $\begin{array}{c}\text { Formação } \\
\text { Florestal }\end{array}$ & $\begin{array}{r}\text { Corpos } \\
\text { de água }\end{array}$ \\
\hline \multirow{3}{*}{$\begin{array}{c}\text { Densidade e } \\
\text { Tamanho }\end{array}$} & $\begin{array}{c}\text { Número de } \\
\text { Fragmentos } \\
\text { (Adimensional) }\end{array}$ & 31 & 25 & 145 & 243 & 5 & 96 & 20 & 166 & 217 & 10 \\
\hline & $\begin{array}{c}\text { Tamanho Médio } \\
\text { do Fragmento } \\
\text { (ha) }\end{array}$ & 91,40 & 31,63 & 171,82 & 51,96 & 39,63 & 58,90 & 59,83 & 130,37 & 58,32 & 21,41 \\
\hline & $\begin{array}{l}\text { Desvio Padrão } \\
\text { do tamanho do } \\
\text { fragmento (ha) }\end{array}$ & 275,26 & 57,78 & $1.571,26$ & 303,08 & 44,41 & 398,43 & 100,45 & $1.256,57$ & 312,76 & 29,67 \\
\hline \multicolumn{7}{|c|}{ Ano 2010} & \multicolumn{5}{|c|}{ Ano 2017} \\
\hline Grupo & Métrica & $\begin{array}{c}\text { Área } \\
\text { Urbana }\end{array}$ & $\begin{array}{c}\text { Área de } \\
\text { Mineração }\end{array}$ & $\begin{array}{c}\text { formação } \\
\text { Campestre }\end{array}$ & $\begin{array}{r}\text { Formação } \\
\text { Florestal } \\
\end{array}$ & $\begin{array}{c}\text { Corpos de } \\
\text { água }\end{array}$ & $\begin{array}{c}\text { Área } \\
\text { Urbana }\end{array}$ & $\begin{array}{c}\text { Área de } \\
\text { Mineração }\end{array}$ & $\begin{array}{c}\text { Formação } \\
\text { Campestre }\end{array}$ & $\begin{array}{c}\text { Formação } \\
\text { Florestal } \\
\end{array}$ & $\begin{array}{r}\text { Corpos } \\
\text { de água }\end{array}$ \\
\hline \multirow{3}{*}{$\begin{array}{l}\text { Densidade e } \\
\text { Tamanho }\end{array}$} & $\begin{array}{c}\text { Número de } \\
\text { Fragmentos } \\
\text { (Adimensional) } \\
\end{array}$ & 68 & 20 & 171 & 183 & 14 & 230 & 25 & 209 & 208 & 8 \\
\hline & $\begin{array}{c}\text { Tamanho Médio } \\
\text { do Fragmento } \\
\text { (ha) }\end{array}$ & 121,28 & 86,03 & 110,56 & 66,84 & 18,39 & 50,92 & 82,08 & 77,17 & 53,88 & 32,65 \\
\hline & $\begin{array}{l}\text { Desvio Padrão } \\
\text { do tamanho do } \\
\text { fragmento (ha) }\end{array}$ & 632,16 & 124,19 & 824,70 & 309,98 & 27,69 & 416,53 & 154,25 & 464,99 & 302,25 & 33,25 \\
\hline
\end{tabular}




\subsection{FORMA}

Esse índice variou de 1,84 para 1,96 para formação campestre, demonstrando que grande parte das manchas possuem formas mais alongadas e recortadas. $O$ mesmo ocorreu para formação florestal, passando de 1,86 para 2,02. Tanto para formação florestal como para a formação campestre tiveram um aumento do índice de forma médio (Tabela 4).
Portanto, continuam sendo considerados como irregulares e susceptíveis ao efeito borda. Esse aumento descreve que com passar dos anos avaliados a suscetibilidade desses ambientes aumentaram em relação à pressão antrópica exercida pela urbanização e mineração.

Tabela 6 - Métricas da Ecologia da Paisagem de Forma Médio para os anos 1992, 2001, 2010 e 2017.

\begin{tabular}{|c|c|c|c|c|c|c|c|c|c|}
\hline & & \multicolumn{2}{|c|}{ Ano 1992} & \multicolumn{2}{|c|}{ Ano 2001} & \multicolumn{2}{|c|}{ Ano 2010} & \multicolumn{2}{|c|}{ Ano 2017} \\
\hline Grupo & Métrica & $\begin{array}{l}\text { Formação } \\
\text { Campestre }\end{array}$ & $\begin{array}{r}\text { Formação } \\
\text { Florestal }\end{array}$ & $\begin{array}{l}\text { Formação } \\
\text { Campestre }\end{array}$ & $\begin{array}{c}\text { Formação } \\
\text { Florestal }\end{array}$ & $\begin{array}{l}\text { Formação } \\
\text { Campestre }\end{array}$ & $\begin{array}{r}\text { Formação } \\
\text { Florestal }\end{array}$ & $\begin{array}{l}\text { Formação } \\
\text { Campestre }\end{array}$ & $\begin{array}{r}\text { Formação } \\
\text { Florestal }\end{array}$ \\
\hline Forma & $\begin{array}{c}\text { Índice de Forma } \\
\text { médio } \\
\text { (Adimensional) }\end{array}$ & 1,84 & 1,86 & 1,84 & 1,91 & 1,89 & 1,94 & 1,96 & 2,02 \\
\hline
\end{tabular}

\section{3 ÁREA NUCLEAR}

Analisando a distância de 100m entre os fragmentos os valores encontrados de áreas centrais foram maiores que os valores dos números de fragmentos, tanto para a formação florestal quanto para a formação campestre. Esse evento é denominado como áreas-núcleo disjuntivas. Ou seja, os números dos fragmentos foram subdivididas em diversas áreas, criando áreas de habitats ilhadas. Logo, conclui-se que são fragmentos vulneráveis ao efeito borda, resultando em uma diminuição significativa da área de habitats efetivamente utilizáveis (FORMAN, 1995). Considerando que a forma dos fragmentos, conforme mencionado anteriormente, tende a ser irregular, entendese que provavelmente haja um relevante efeito de borda em um grande número de fragmentos da área avaliada (Tabela $5 \mathrm{e}$ Figura 6).

O número de áreas centrais pode ser confirmado quando analisado o tamanho da área total e do índice de área central que tiveram uma diminuição, o que confirma a fragmentação e o efeito borda (Tabela 5 e Figura 6). A Formação Campestre perdeu 5.685,38 ha de área central total, o equivalente a 44,18\%. Em relação ao índice de área também houve uma perda de 7,12\%, passando de 51,41\% em 1992 para 44,29\% em 2017. Já a formação florestal teve uma perda de 1.089,66 ha, o equivalente a $23,44 \%$. Em relação ao índice de área também houve uma perda de 5,06\%. 
Figura 6: (a) Número de áreas centrais; (b) Área Central Total; (c) Forma Médio

(a)

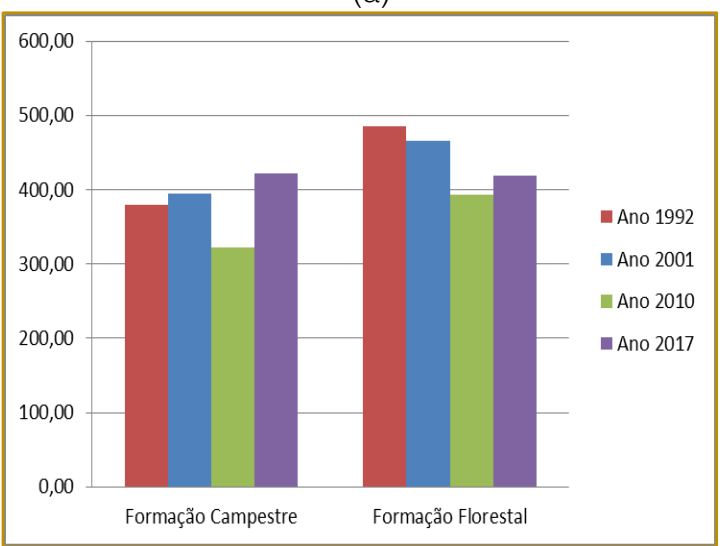

(b)

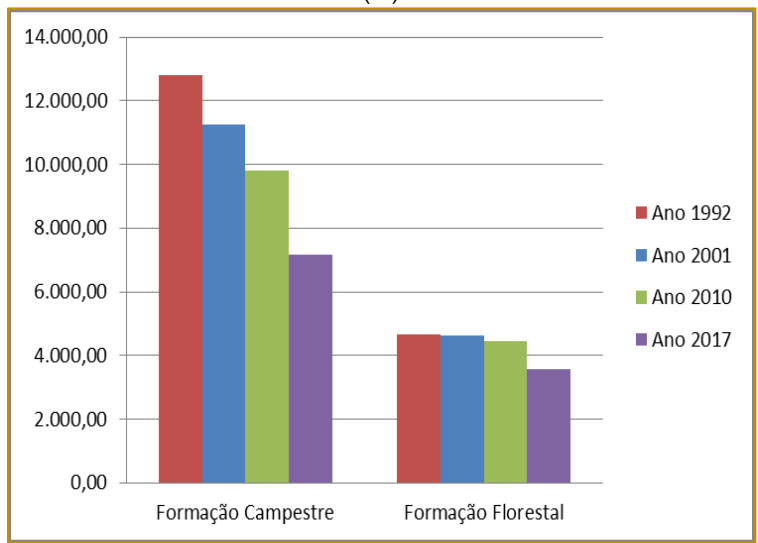

(c)

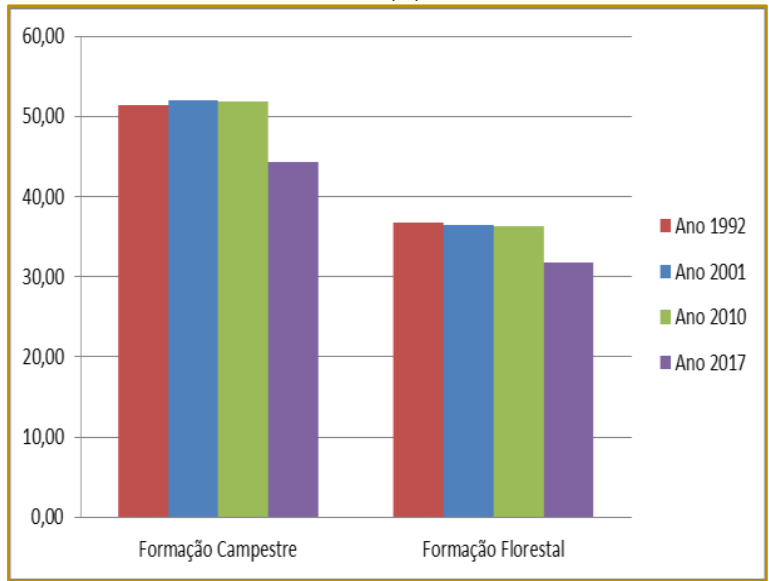

Tabela 5 - Métricas da Ecologia da Paisagem de Área Nuclear para os anos 1992, 2001, 2010 e 2017.

\begin{tabular}{|c|c|c|c|c|c|c|c|c|c|}
\hline \multirow[b]{2}{*}{ Grupo } & \multirow[b]{2}{*}{ Métrica } & \multicolumn{2}{|c|}{ Ano 1992} & \multicolumn{2}{|c|}{ Ano 2001} & \multicolumn{2}{|c|}{ Ano 2010} & \multicolumn{2}{|c|}{ Ano 2017} \\
\hline & & $\begin{array}{l}\text { Formação } \\
\text { Campestre }\end{array}$ & $\begin{array}{c}\text { Formação } \\
\text { Florestal }\end{array}$ & $\begin{array}{l}\text { Formação } \\
\text { Campestre }\end{array}$ & $\begin{array}{c}\text { Formação } \\
\text { Florestal }\end{array}$ & $\begin{array}{l}\text { Formação } \\
\text { Campestre }\end{array}$ & $\begin{array}{c}\text { Formação } \\
\text { Florestal }\end{array}$ & $\begin{array}{l}\text { Formação } \\
\text { Campestre }\end{array}$ & $\begin{array}{r}\text { Formação } \\
\text { Florestal }\end{array}$ \\
\hline \multirow{3}{*}{$\begin{array}{c}\text { Área } \\
\text { Nuclear }\end{array}$} & $\begin{array}{c}\text { Número de } \\
\text { áreas centrais } \\
\text { (admensional) }\end{array}$ & 379 & 485 & 394 & 466 & 322 & 393 & 422 & 419 \\
\hline & $\begin{array}{c}\text { Area Central } \\
\text { total (ha) }\end{array}$ & $12.808,80$ & $4.648,02$ & $11.259,48$ & $4.609,54$ & $9.793,04$ & $4.437,38$ & $7.150,42$ & $3.558,36$ \\
\hline & $\begin{array}{c}\text { Índice de área } \\
\text { central (\%) }\end{array}$ & 51,41 & 36,81 & 52,03 & 36,42 & 51,80 & 36,28 & 44,29 & 31,75 \\
\hline
\end{tabular}

\subsection{PROXIMIDADE}

Foi observado um aumento na média de distância do vizinho mais próximo, tanto para a formação florestal como para a formação campestre. Para formação Campestre foi de 67,35m no ano de 1992 para 109,53m no ano 2017, uma diferença de 42,18m. Para Formação Florestal foi de $123,74 \mathrm{~m}$ no ano de 1992 para 151,73m no ano de 2017, uma diferença de 27,99m (Tabela 6) Isso significa uma pressão intensa sobre os fragmentos, aumentando a dificuldade dos animais atravessarem de um fragmento ao outro. Apesar da distância do vizinho mais próximo ser uma indicação direta de conectividade estrutural, é possível que a fragmentação subdivida uma área grande em várias menores, criando novas manchas de habitat próximas e possivelmente aumentado a distância média do vizinho mais próximo. 
Tabela 6 - Métricas da Ecologia da Paisagem de Proximidade para os anos 1992, 2001, 2010 e

\begin{tabular}{|c|c|c|c|c|c|c|c|c|c|}
\hline \multirow[b]{2}{*}{ Grupo } & \multirow[b]{2}{*}{ Métrica } & \multicolumn{2}{|c|}{ Ano 1992} & \multicolumn{2}{|c|}{ Ano 2001} & \multicolumn{2}{|c|}{ Ano 2010} & \multicolumn{2}{|c|}{ Ano 2017} \\
\hline & & $\begin{array}{l}\text { Formação } \\
\text { Campestre }\end{array}$ & $\begin{array}{c}\text { Formação } \\
\text { Florestal }\end{array}$ & $\begin{array}{l}\text { Formação } \\
\text { Campestre }\end{array}$ & $\begin{array}{c}\text { Formação } \\
\text { Florestal }\end{array}$ & $\begin{array}{l}\text { Formação } \\
\text { Campestre }\end{array}$ & $\begin{array}{c}\text { Formação } \\
\text { Florestal }\end{array}$ & $\begin{array}{l}\text { Formação } \\
\text { Campestre }\end{array}$ & $\begin{array}{c}\text { Formação } \\
\text { Florestal }\end{array}$ \\
\hline Proximidade & $\begin{array}{l}\text { Distância do } \\
\text { vizinho mais } \\
\text { próximo (m) }\end{array}$ & 67,35 & 123,74 & 87,66 & 147,51 & 105,94 & 151,82 & 109,53 & 151,73 \\
\hline
\end{tabular}

\subsection{DIVERSIDADE}

O índice de diversidade de Shannon (SDI) de 0,95 para 1992 e 1,26 para 2017, sendo que esses valores denotam a diversidade dos usos na área analisada. Um aumento desse índice pode ser explicado pela alteração no arranjo da paisagem e distribuição das classes na paisagem (Tabela 7).

O aumento do outro índice de diversidade, Índice de Equitatibilidade de Shannon, de 0,59 em 1992 para 0,78 em 2017, evidencia essa mudança no arranjo e a distribuição das classes, gerando nesse caso um processo de fragmentação quando observado em conjunto com os demais índices (Tabela 7).

Alinhado com esses dois índices foi avaliado a proporção de representatividade das classes analisadas. Quando analisada a proporção de representatividade reafirma as análises já adquiridas até o momento. Houve um aumento das classes de áreas urbanas e mineração e consequentemente uma diminuição das classes de formação campestre e florestal

Tabela 7 - Métricas da Ecologia da Paisagem de Diversidade para os anos 1992, 2001, 2010 e 2017.

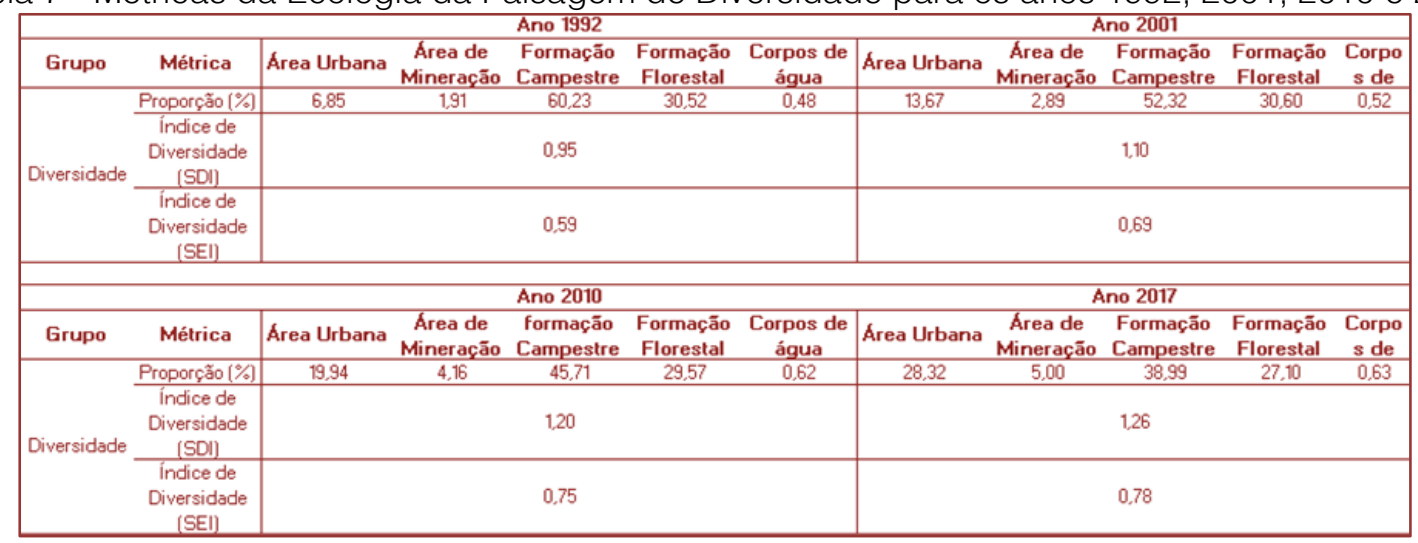

\subsection{BARREIRAS DE EXPANSÃO URBANA E MINERÁRIA}

A região de estudo apresenta uma tendência marcante da expansão de Área Urbana e Minerária. Detectou-se por este estudo essa expansão, dentro da área-alvo, com um crescimento de aproximadamente $313,36 \%$ para área urbana e $159,59 \%$ para área de mineração (Tabela 5). Existem áreas que poderiam ser denominadas como "barreiras de impedimento" dessa expansão, as áreas de preservação permanente e áreas de unidades de conservação. Entretanto, mesmo possuindo uma jurisprudência para conservação e manutenção dos ecossistemas e biodiversidade através dessas áreas é perceptível que existe uma lacuna no cumprimento da legislação.

\section{7 ÁREAS ANTRÓPICAS EM ÁREAS DE CONSERVAÇÃO E APPS}

Sobrepondo-se as Unidades de Conservação e as Áreas de Preservação Permanente às classes de cobertura vegetacional e uso do solo do ano de 2017 (Figura 7), percebe-se que existe uma grande ocupação de atividades antrópicas em áreas que originalmente eram destinadas à proteção ambiental. 
Figura 7 - Áreas conflitantes com Unidades de Conservação - Usos Sustentável e Proteção integral (E) e com APPs (F).

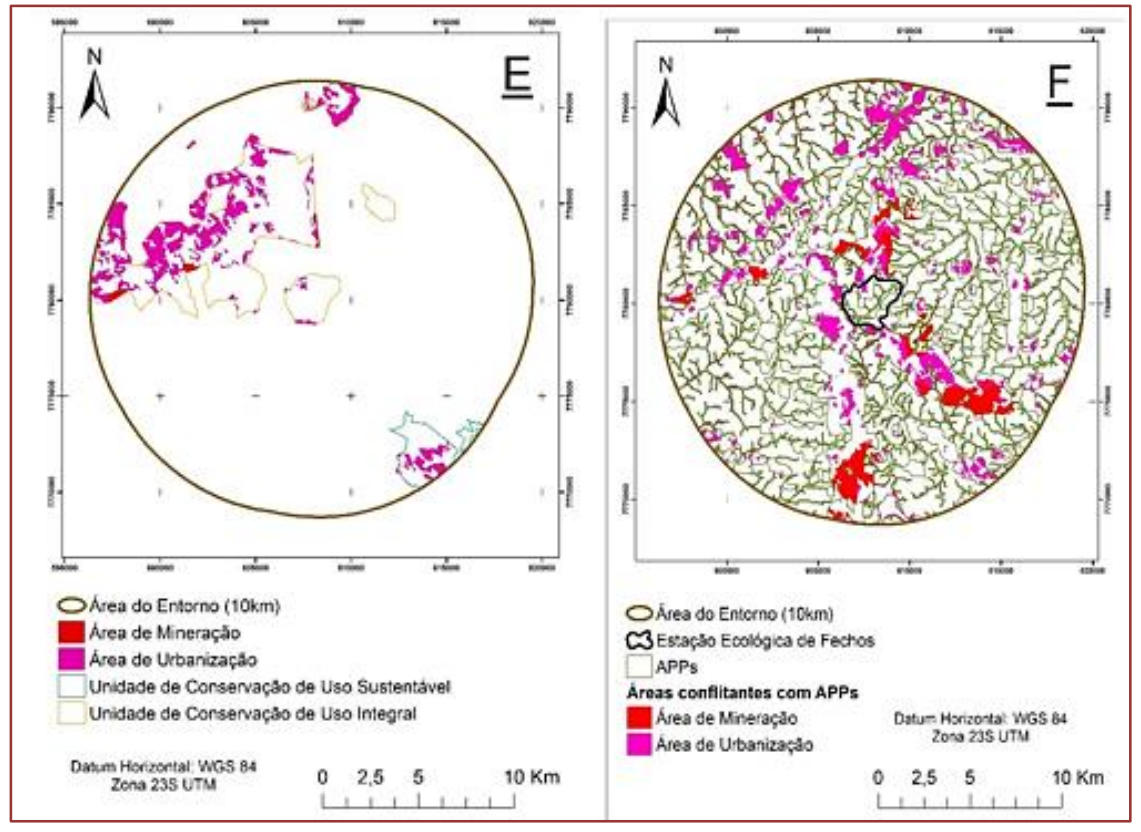

Segundo a Lei $n^{\circ}$ 9.985/2000 do SNUC as unidades de conservação são divididas em duas categorias unidades, denominadas como: Proteção Integral e de Uso Sustentável. Para a primeira categoria é definido somente o uso indireto dos recursos naturais existentes dentro dos limites da unidade de conservação, pois seu objetivo é preservar integralmente. Já a segunda categoria, como o objetivo é conciliar a conservação da natureza com a possiblidade do uso dos seus recursos naturais e assim define a possibilidade do uso de uma parte dos recursos naturais, sendo de maneira sustentável.

Identificou que $13,81 \%$ das áreas destinadas às unidades de conservação, da categoria uso sustentável, são áreas de urbanização (

Tabela ). Com relação às áreas destinadas às unidades de Proteção Integral, para o ano de 2017, 36,13\% são áreas de mineração $(12.990,11$ ha) e 21,94\% são áreas de urbanização (um equivalente a 7.889,84 ha) (Tabela ).

Tabela 8 - Áreas Mineração X Unidades de Conservação

\begin{tabular}{|cccc|}
\hline Classe Original & Classe Alterada & Área (ha) & Proporção (\%) \\
\hline Unidade de Uso Sustentável & Área de urbanização & 813,75 & 13,81 \\
\hline
\end{tabular}

Tabela 9 - Áreas de Mineração e Urbanização X Unidades de Proteção Integral

\begin{tabular}{|cccc|}
\hline Classe Original & Class e Alterada & Área (ha) & Proporção (\%) \\
\hline \multirow{2}{*}{ Unidade de Proteção Integral } & Área de mineração & $12.990,11$ & 36,13 \\
\cline { 2 - 4 } & Área de urbanização & $7.889,84$ & 21,94 \\
\hline
\end{tabular}

As Áreas de Preservação Permanente foram substituídas em 8,27\% por áreas de mineração (1.382,97 ha) e em 25,21\% por áreas de urbanização, representando 4.213,50 ha (Tabela 10). 
Tabela 10- Áreas Mineração e Urbanização X APPs.

\begin{tabular}{|cccc|}
\hline Classe Original & Classe Alterada & Área (ha) & Proporção (\%) \\
\hline \multirow{2}{*}{ APPs } & Área de mineração & $1.382,97$ & 8,27 \\
\cline { 2 - 4 } & Área de ưbanização & $4.213,50$ & 25,21 \\
\hline
\end{tabular}

\subsection{SISTEMA VIÁRIO COMO CONTRIBUINTE PARA EXPANSÃO URBANA E MINERÁRIA}

Um fator que está proporcionalmente ligado à expansão minerária e principalmente urbana é o sistema viário (NASCIMENTO e MATIAS, 2011). A existência de infraestrutura contribui para o crescimento urbano e muitas vezes este crescimento ocorre sem um planejamento urbano.

Na área-alvo é perceptível que a existência de infraestrutura viária possivelmente induzindo a expansão da urbanização e mineração. Como as áreas a noroeste estão bastante adensadas, em análise a Figura 8 , existe um crescimento pequeno à nordeste e leste, que em conjunto com o sistema viário, pode proporcionar um estímulo à expansão urbana. Bem como já ocorre ao sul de maneira mais intensa. Principalmente, quando o tipo de expansão urbana, que no caso da região acontece está ligada ao bem estar e qualidade de vida relacionado à cobertura vegetal existente fortemente na área. Análises quantitativas devem ser conduzidas para confirmar tais padrões qualitativos.

Figura 8- Rodovias presentes na área de estudo

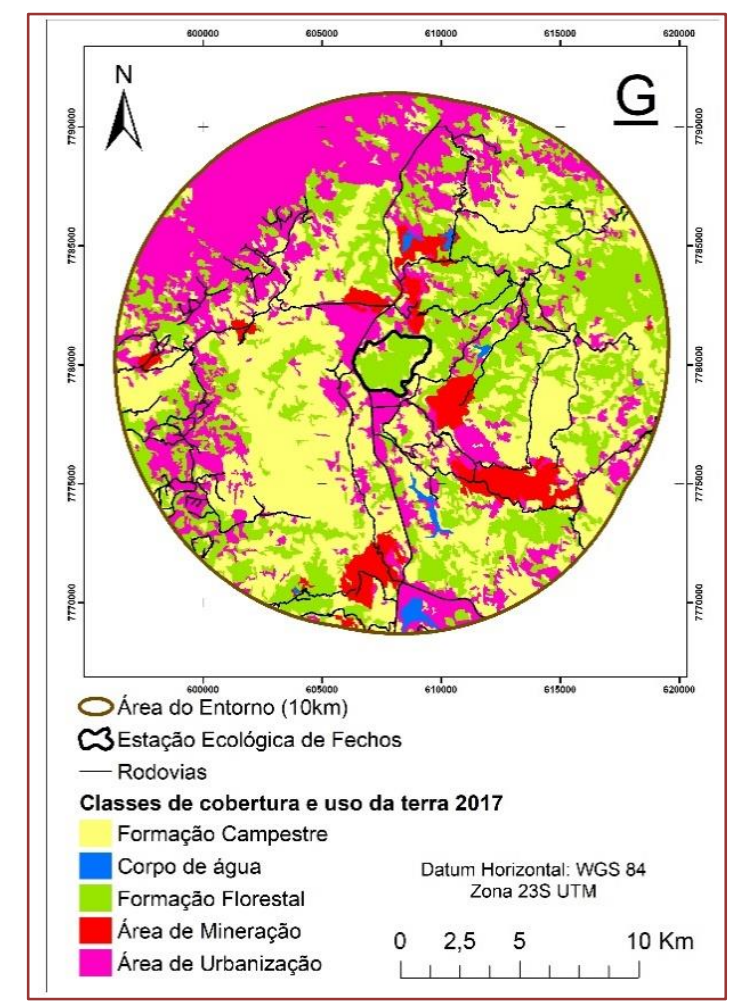




\section{CONCLUSÃO}

O presente trabalho possibilitou realizar uma análise espacial das mudanças de cobertura vegetal e tipos de uso do solo nos últimos 25 anos do entorno da Estação Ecológica de Fechos, permitindo identificar pressões antrópicas sofridas na área de estudo, através de técnicas de geoprocessamento e ecologia da paisagem.

A partir dessa análise espacial temporal possibilitou verificar que o entorno da E.E. de Fechos sofre uma intensa pressão antrópica sobre a cobertura vegetal devido à expansão urbana e minerária. As análises das métricas

\section{REFERÊNCIAS}

[1] Brasil, 2000. Lei Federal n. 9.985, de 18 de julho de 2000. Institui o Sistema Nacional de Unidades de Conservação da Natureza - SNUC. Disponível em: 13/11/2017 Acesso em: < http://www.planalto.gov.br/ccivil_03/I> nov. 2017.

[2] Brasil. Decreto no 36.073, de 27 de setembro de 1994. Cria a Estação Ecológica de Fechos. Diário do Executivo - Minas Gerais.

[3] Brito, F. Corredores Ecológicos: Uma Estratégia Integradora na Gestão de Ecossistemas. Florianópolis, Ed. Da UFSC, 2006.

[4] Cabacinha, C. D.; Castro, S. S.; Gonçalves, D. A. Análise da estructura da paisagem da alta bacia do rio Araguaia na Savana Brasileira. Floresta. Curitiba, PR, v. 40, n. 4, p. 675690, out/dez. 2010.

[5] Costa, D. R. T. R. et al. Zonas de Amortecimento em Unidades de Conservação: levantamento legal e comparativo das normas nos Estados de Minas Gerais, Rio de Janeiro e São Paulo. Desenvolvimento e Meio Ambiente. v. 27, p. 57-70, jan./jun. 2013. Editora UFPR.

[6] Instituto Estadual de Florestas (IEF), 2017. Disponível em: <http://www.ief.mg.gov.br> Acesso em: 13/11/2017

[7] Filho, B.S.S. Análise de Paisagem: Fragmentação e Mudanças. Departamento de Cartografia. Centro de Sensoriamento Remoto Insituto de Geociências - UFMG, 1998.

[8] Forman, R. T. T. Land mosaics: The Ecology of Landscapes and Region. New York: Cambridge Press, 1995. 632p.

[9] Forman, R.T.T. \& Godron, M. Landscape Ecology. New York: John Wiley, 1986.

[10] Leão, C.; Krug, L. A.; Kampel, M.; fonseca, L. M. G. Avaliação de métodos de classificação em imagens TM/Landsat e CCD/CBERS para 0 mapeamento do uso e cobertura da terra na região costeira do extremo sul da Bahia. In: Simpósio da paisagem possibilitaram verificar que as alterações da paisagem geradas por atividades antrópicas causam a fragmentação da vegetação natural e o isolamento de unidades de conservação, resultando em uma maior exposição e perturbações externas destes ambientes.

Dessa forma, é necessário um controle planejado do uso do solo na área do entorno da E.E. de Fechos com medidas de gestão pública, para que essa unidade não se torne apenas uma ilha de preservação, visto a necessidade do fluxo de algumas espécies fundamentais para a manutenção da área de estudo.

Brasileiro de Sensoriamento Remoto, 13., 2007, Florianópolis. São José dos Campos, INPE, 2007. p. 939-946.

[11] Lucas, D.F. Análise Espacial das Fragmentos Florestais no Município de São Gonçalo do Rio Abaixo/MG. Curso de Especialização em Geoprocessamento, Instituto de Geociências, Universidade Federal de Minas Gerais, 2011.

[12] Martins, É. S. el al. Ecologia da Paisagem: Conceitos e Aplicações Potenciais no Brasil. Documentos, Platina, DF. n.121, p.1-35, jul. 2004.

[13] Moreira, C. A. S. Alteração da Paisagem e Comportamento do Fogo na Freguesia de França, Bragança. Tese de mestrado Em Gestão e Conservação da Natureza. Instituto Politécnico de Bragança. Dezembro, 2008.

[14] Nascimento, E.; Matias, L. F. Expansão Urbana e Desigualdade Socioespacial: Uma Análise da Cidade de Ponta Grossa (PR). RA'E GA 23 (2011), p. 65-97. Curitiba, Departamento de Geografia - UFPR ISSN: 2177-2738

[15] Pirovani, D. B. Silva, A. G., Santos, A. R. Análise da Paisagem e Mudanças no Uso da Terra no Entorno da RPPN Cafundó, ES. DOI: 10.1590/01047760201521011182. Revista CERNE, v. 21 n. 1, p. 27-35, 2015. ISSN 0104-7760.

[16] Pirovani, D. B. Fragmentação, florestal, dinâmica e ecologia da paisagem na bacia hidrográfica do rio Itapemirim, ES. Dissertação (mestrado) - Universidade Federal do Espírito Santo. Centro de Ciências Agrárias, 2010.

[17] Silva, M. S. F.; Souza, R. M. Padrões Espaciais de Fragmentação Florestal na Flona do Ibura - Sergipe. DOI: 10.4215/RM2014.1303.0009. Mercator, Fortaleza, v. 13, n. 3, p. 121-137, set./dez. 2014.

[18] Turner, M.G.; Gardner, R. H. 1990. Quantitative methods in landscape ecology: the 
analysis and interpretation of landscape heterogeneity. New York: Springer Verlag, 536 p.

[19] Viana, V.M.; Tabanez, A.J.A; Matinez, J.L.A.1992. Restauração e Manejo de Fragmentos Florestais. Anais. 20 Congresso Nacional sobre Essências Nativas. 29 mar 1992.
[20] Zaú, A.S. Fragmentação da Mata Atlântica: Aspectos Teóricos. Floresta e Ambiente, v.5, p. 160 - 170, Janeiro 1998. 


\section{Capítulo 7}

\section{CONDUTÂNCIA ESTOMÁTICA, FOTOSSINATESE E TRANSPIRACÃO DE EUCALYPTUS SOB CONDICCÕES DE DÉFICIT HÍDRICO}

\section{Renata Teixeira de Almeida Minhoni}

\section{Glaucia Regina Santos}

Ana Clara de Barros

Ana Paula Leite

Resumo: O estresse hídrico provoca um impacto negativo nas variáveis fisiológicas da planta, prejudicando o seu desenvolvimento e causando perdas na produtividade florestal. O objetivo deste trabalho foi realizar uma revisão de literatura sobre pesquisas que abordaram o comportamento de espécies do gênero Eucalyptus, submetidas a condições de déficit hídrico. Foram utilizadas informações nacionais e internacionais para o embasamento deste trabalho. Assim, foram reunidos resultados de pesquisas a respeito de três variáveis fisiológicas das plantas: condutância estomática, fotossíntese e transpiração. Verificou-se nos trabalhos consultados que as condições de déficit hídrico interferiram nas respostas fisiológicas, das três variáveis pesquisadas, de diferentes espécies de Eucalyptus. Este fato evidencia a importância da seleção de espécies com maior resistência à seca, como forma de se garantir um maior desenvolvimento e uma produtividade florestal.

Palavras-chave: escassez hídrica; estresse hídrico; eucalipto; silvicultura. 


\section{INTRODUÇÃO}

Em 2015 o Brasil apresentou uma área total de árvores plantadas de 7,8 milhões de hectares, sendo que 5,6 milhões de hectares estavam relacionadas ao plantio de árvores do gênero Eucalyptus, destacando-se os estados de Minas Gerais, com 24\%, São Paulo, com 17\% e Mato Grosso do Sul, com 15\% (IBÁ, 2016). O Brasil possui relevância mundial na área florestal, tanto para árvores nativas como para árvores plantadas, principalmente as de eucalipto (CARVALHO; SOARES; VALVERDE, 2005).

Popularmente conhecidas como eucalipto, essas árvores compõem um grupo de espécies que formam o gênero Eucalyptus, caracterizado como sendo um dos maiores gêneros de plantas do mundo (FLORES et al., 2016). Trata-se de uma planta exótica originada na Austrália, Nova Guiné, Indonésia e Filipinas, que foi introduzida no Brasil em meados do século XIX. As espécies mais utilizadas no Brasil são o eucalipto Grandis (móveis e casas), Citriodora (construção civil), Saligna (telhados), Tereticornis (estruturas pesadas) e Cloeziana (construção civil e rural), cuja madeira apresenta elevada qualidade (SCOLFORO, 2008).

Entre os produtos fornecidos pelas florestas de eucalipto, estão a madeira para celulose, a lenha, carvão vegetal e, em expansão, produtos de madeira maciça e óleos essenciais (COOK; BINKLEY; STAPE, 2016). Resíduos florestais, como cavacos, galhos, cascas e folhas de eucalipto, provenientes da indústria de papel e celulose, podem ser utilizados na geração de eletricidade e de calor. Da mesma maneira que o etanol, o biodiesel, resíduos alimentares, domésticos e municipais, estes resíduos são considerados como produtos bioenergéticos, que podem ser utilizados para geração de energia renovável (GASPARATOS et al., 2017).

O plantio do eucalipto está sendo realizado com frequência em áreas que apresentam alta demanda atmosférica e baixa e desigual precipitação anual, interferindo no sucesso da floresta e em sua produtividade (XAVIER, 2010). O eucalipto é comumente plantado em regiões de bioma cerrado, locais com solos de baixa fertilidade e propensos a longas temporadas de déficit hídrico (SILVA et al., 2014). O plantio do eucalipto nessas regiões é resultado do crescimento da demanda por produtos florestais e do desenvolvimento de tecnologias no manejo florestal (BARBOSA; HODECKER; BARROS, 2016).

Pesquisas no sentido de se verificar a tolerância à seca pelo eucalipto podem contribuir com uma melhora na produtividade e o no comércio das árvores em regiões com longos períodos de seca ou áridas (MATOS et al., 2016). Tais pesquisas caminham no sentido de se selecionar genótipos, com potencial de uso comercial, capazes de tolerar ambientes com déficit hídrico, exigindo estudos a respeito de fatores anatômicos, bioquímicos, fisiológicos e moleculares (BARBOSA; HODECKER; BARROS, 2016).

Ao perceberem condições de déficit hídrico as plantas ativam diversas respostas para sincronizarem seu desenvolvimento e atividades moleculares, como forma de defesa para sua sobrevivência (VALDÉS et al., 2013). Essas respostas influenciam na morfologia e na fisiologia das plantas, para que possam se adaptar as condições de estresse hídrico do meio (FERRAZ, 2012; PIMENTEL, 2005).

Com o intuito de contribuir com as pesquisas e para um melhor entendimento do comportamento do eucalipto frente a condições de déficit hídrico, este artigo teve como objetivo realizar uma revisão de literatura sobre déficit hídrico e sua relação com os principais aspectos fisiológicos e morfológicos da cultura do eucalipto.

\section{DESENVOLVIMENTO}

\subsection{DÉFICIT HÍDRICO}

As plantas enfrentam inúmeros fatores relacionados ao estresse ambiental, conhecidos como "estresse abiótico", no qual fazem parte $\mathrm{O}$ déficit hídrico, a salinidade, temperaturas extremas e a baixa concentração de oxigênio no meio (VALDÉS et al., 2013), e também a nutrição deficiente, a matocompetição, as doenças, as pragas, danos mecânicos e danos causados por animais (LOPES et al., 2009). Identificar quando esses fatores abióticos são limitantes para o crescimento das plantas é importante para compreender como esses déficits podem ser atenuados.

O déficit hídrico, um dos principais fatores que interferem da produção agrícola e florestal, ocorre quando o volume de água 
disponível para as raízes da planta se torna limitante ou quando ocorre uma elevada taxa de transpiração (LISAR et al.,2012). Para se adaptarem as condições de déficit hídrico, as plantas reduzem o potencial hídrico juntamente com ajustes fisiológicos, anatômicos e morfológicos, não existindo um procedimento universal de combate à escassez de água (NOGUEIRA et al., 2005). Adicionalmente, o déficit hídrico ocasiona a maior exploração do sistema radicular em direção a zonas mais profundas e úmidas ao longo do perfil do solo (SANTOS; CARLESSO, 1998).

O estresse sofrido pelas plantas pode ser reversível ou irreversível (LARCHER, 2004), sendo que a eficiência na utilização da água pode ser entendida como sendo uma estratégia de adaptação, por meio da qual a planta adquire maior elasticidade para enfrentar situações de déficit hídrico (LIMA, 1995). Assim, a adaptação e aclimatação as condições de estresse do meio são provenientes de eventos que acontecem nos níveis anatômico, morfológico, celular, molecular e bioquímico, ou seja, em todos os níveis de organização (LOPES et al., 2011).

Para o caso do eucalipto, a fase de muda é mais afetada pela condição de déficit hídrico, pois são quando os sintomas são mais drásticos e mais fáceis de serem identificados (SILVA, et al., 2004). Dessa maneira, o comportamento do eucalipto frente ao déficit hídrico vem sendo intensivamente estudado, pois a restrição de água é a principal limitação para sua produção e ganhos econômicos (STAPE et al., 2008).

\subsection{ASPECTOS FISIOLÓGICOS}

A ação de abertura e o fechamento dos estômatos é definida pela absorção e pela redução de água nas células-guarda, localizadas na epiderme foliar, que perdem turgor devido à perda de água para a atmosfera (TAIZ et al., 2017). Desse modo, as influências do ambiente sobre o controle estomático são de fundamental importância tanto para amenizar os efeitos do estresse hídrico como para a manutenção da produtividade (Otto et al. 2013).

Frente ao déficit hídrico, primeiramente as plantas tendem a fechar os estômatos como forma de se evitar a perda de água pela transpiração, sendo que a diminuição da condutância estomática possibilita uma melhor manutenção da água, evitando danos excessivos à sua atividade metabólica (SENGUPTA; KANNAN; REDDY, 2011). A continuação da situação de déficit hídrico promove uma redução no fechamento estomático, mas não ocorre a redução da pressão do xilema (CHOAT, 2012). Assim, de acordo com os mesmos autores, caso o solo não seja reabastecido com água antes da ocorrência da completa falha hidráulica, a planta poderá morrer por dessecação. Desse modo, a redução da perda de água por meio do fechamento dos estômatos e a contínua absorção de água e nutrientes pelas raízes são mecanismos essenciais para a sobrevivência das plantas em situações de estresse hídrico.

Segundo McAdam, Sussmilch e Brodribb (2016) a regulação do uso da água pelas plantas se dá pelo movimento de abertura e fechamento das células guarda nos estômatos, e uma evidência reconhecida que desencadeia este processo é a alteração na umidade do ar, especificamente, a alteração no déficit de pressão de vapor entre a folha e a atmosfera. Além das variações da umidade do ar e da condição de hidratação da folha, a luz também é um dos principais fatores relacionados ao processo de abertura e fechamento dos estômatos (COSTA; MARENCO, 2007). Assim, uma vez que se estabelece o estresse hídrico, ocorrerá a redução na condutância estomática.

Otto et al. (2013) conduziram estudos utilizando quatro clones de Eucaliptus, com o objetivo de avaliar a condutância estomática, a fotossíntese e a produtividade. Para isso, os autores instalaram experimentos em área úmida e em área seca. Em relação à condutância estomática, os autores concluíram que na área úmida todos os clones apresentaram sua condutância estomática reduzida em relação ao aumento do déficit de pressão de vapor, e na área seca não encontraram relação entre a condutância estomática e o déficit de pressão de vapor, pois, em todos os clones, os estômatos de mantiveram praticamente fechados no decorrer do período do experimento.

Zhu et al. (2015) realizaram estudos, nas estações seca e chuvosa, com duas espécies de eucalipto, Eucalyptus grandis e Eucalyptus urophyla, com cinco anos de idade. Dentre outros fatores, os autores analisaram a condutância estomática, que apresentou uma relação linear com o déficit 
de pressão de vapor para ambas as espécies. Os valores de condutância estomática reduziram com o aumento do déficit de pressão de vapor, apresentando os menores valores na época seca. Os autores concluíram que as duas espécies de eucalipto apresentaram variações semelhantes em relação ao uso da água nas épocas analisadas.

Marrichi (2009) realizou uma pesquisa abordando variáveis fisiológicas em sete clones de Eucalyptus em resposta ao déficit de pressão de vapor, realizando medições aos dezesseis e aos trinta e seis meses. Segundo a autora, para todos os clones, houve redução da condutância estomática frente ao aumento do déficit de pressão do autor, sendo está relação mais acentuada aos dezesseis meses. Assim, Otto et al. (2013), Zhu et al. (2015) e Marrichi (2009) encontraram resultados semelhantes para 0 comportamento da condução estomática em relação ao déficit da pressão de vapor. Porém, Marriche (2009) ressalta que as sensibilidades dos clones ao estresse hídrico foram diferentes, o que reforça a necessidade de se conhecer a potencialidade hídrica local para a seleção mais adequada de espécies e clones de eucalipto.

\subsection{FOTOSSÍNTESE}

A fotossíntese é um processo fisiológico importante no crescimento e desenvolvimento das plantas, pois ocorre a transformação de energia luminosa em energia química, por meio de moléculas de matéria orgânica (TAlZ et al., 2017). Assim, qualquer alteração ambiental que interfira na fotossíntese poderá afetar no crescimento e acúmulo de fitomassa pela planta.

O comportamento da fotossíntese em relação ao estresse hídrico é extremamente complexo, pois envolve interações que ocorrem em diversos locais das células presentes nas folhas e em diferentes estágios de desenvolvimento das plantas (CHAVES; FLEXAS; PINHEIRO, 2009). Condições de déficit hídrico induzem o fechamento dos estômatos, o que prejudica a absorção de $\mathrm{CO}_{2}$ e, consequentemente, reduz a atividade fotossintética e o crescimento da planta (OSAKABE et al., 2014).

Assim como a condutância estomática, Otto et al. (2013) também avaliaram a fotossíntese de quatro clones de Eucalyptus localizados em regiões com diferentes condições edafoclimáticas, uma úmida e outra seca. Os autores encontraram variação significativa na fotossíntese nas duas regiões estudadas, sendo que na região úmida a taxa fotossintética máxima média dos quatro clones variou de 12,5 a $16,4 \mu \mathrm{mol} \mathrm{m} \mathrm{m}^{-1}$ e na região seca variou de 1,2 a $3,4 \mu \mathrm{mol} \mathrm{m} \mathrm{m}^{-1}$. Essa variação refletiu na produtividade dos clones, que foi 3,3 vezes maior na região úmida em relação à região seca, demonstrando que a fotossíntese é um dos fatores responsáveis pelo ganho de produtividade do Eucalyptus na região úmida.

Héroult et al. (2013) realizaram uma pesquisa com quatro espécies de Eucalyptus, provenientes de regiões com diferentes regimes de precipitação, $E$. cladocalyx (450-650 mm.ano-1), E. melliodora (450-1300 mm.ano $\left.{ }^{-1}\right)$, E. dunnii (1200-1500 $\mathrm{mm} \cdot \mathrm{ano}^{-1}$ ) e E. saligna (900-1800 mm.ano ${ }^{-1}$ ). As espécies foram dispostas em um mesmo local e submetidas a períodos secos e úmidos.

E. dunnii e E. saligna, provenientes de regiões com regime de precipitação mais elevado,

apresentaram os maiores valores de condutância estomática e de taxa fotossintética, quando comparadas as espécies E. cladocalyx e E. melliodora, provenientes de regiões com menor regime de precipitação. Todas as espécies tiveram a condutância estomática reduzida em resposta ao aumento do déficit de pressão de vapor, mas as espécies E. cladocalyx e E. melliodora apresentaram uma queda menos acentuada, evidenciando as diferentes respostas para condutância estomática e para fotossíntese, de acordo com o local de origem de cada espécie e seu respectivo regime hídrico.

Assim como Otto et al. (2013) e Héroult et al. (2013), outros pesquisadores, como Tatagiba et al. (2007) e Vellini et al. (2008), também encontraram resultados similares em suas pesquisas com eucalipto, onde em condições de déficit hídrico as plantas apresentaram redução na atividade fotossintética. Tatagiba et al. (2007) pesquisaram o comportamento árvores adultas de dois clones de Eucalyptus, e encontraram maiores valores para a taxa fotossintética e outras variáveis fisiológicas 
na época chuvosa, em relação à época seca. Vellini et al. (2008) avaliaram a resposta de mudas de dezoito clones de Eucalyptus, submetidos a quatro regimes de irrigação (diária, a cada dois dias, a cada quatro dias e a cada seis dias). Os autores observaram que, no geral, a taxa fotossintética antes dos regimes de irrigação, ou seja, na condição de estresse hídrico, apresentou pouca diferença entre os clones, mas foi inferior na irrigação a cada seis dias.

\subsection{TRANSPIRAÇÃO}

O déficit hídrico desencadeia uma série de processos metabólicos que promovem 0 fechamento parcial ou total dos estômatos. Esse fato limita a perda de água e a fixação de dióxido de carbono para se reduzir o risco de desidratação. Nesse sentido, a taxa de transpiração decresce com o fechamento dos estômatos devido a redução da disponibilidade de água no solo (LARCHER, 2004).

Dessa maneira, além da condutância estomática e da fotossíntese, o déficit hídrico também ocasiona alterações na transpiração do eucalipto (FERNANDES; CAIRO; NOVAES, 2015). Os mesmos autores conduziram estudo em casa de vegetação para avaliar respostas fisiológicas de mudas de quatro clones de eucalipto submetidos a déficit hídrico. Os autores concluíram que a restrição hídrica causou reduções expressivas na transpiração de todos os clones, sem apresentar diferenças significativas entre eles.

Matos et al. (2016) realizaram uma pesquisa com Eucalyptus urocan, com o objetivo de avaliar a tolerância das mudas submetidas ao déficit hídrico. O experimento foi conduzido em uma casa de vegetação e as mudas receberam diferentes lâminas de irrigação. Os autores apontaram que a transpiração apresentou valores crescentes com o aumento da disponibilidade hídrica no solo, ou seja, com o aumento da lâmina d'água aplicada no vaso.

Gentil (2010) avaliou a taxa de transpiração em clones de Eucalyptus em parcelas irrigadas e não irrigadas na cidade de
Eunápolis (BA). Foram instaladas sondas no tronco das árvores para avaliar o fluxo xilemático durante um período de cinco meses. Ao final do experimento concluiu-se que a transpiração média das árvores que receberam irrigação foi igual ou superior, quando comparada as árvores sem irrigação, apresentando valores entre 68 a 79 litros ao longo do período estudado. Este incremento na taxa transpiratória proporcionou um aumento na biomassa, que foi de $16 \mathrm{~kg}$ por árvore na parcela irrigada e $10 \mathrm{~kg}$ por árvores na parcela sem irrigação. Assim, a autora ressalta que a quantidade superior de água perdida no processo de transpiração pelas árvores irrigadas refletiu efetivamente na maior colaboração à fixação de carbono nos troncos.

Pereira et al. (2006), em experimento conduzido em casa de vegetação no município de Botucatu (SP), avaliaram os efeitos do estresse hídrico no comportamento fisiológico de dois clones de Eucalyptus urograndis (105 e 433). A transpiração foi maior em um dos clones, tanto em condições de estresse como não estresse, mas o tratamento sem estresse hídrico teve melhor resposta em ambos os clones estudados.

\section{CONCLUSÕES}

Verificou-se que muitos estudos que abordaram o comportamento do eucalipto em relação ao déficit hídrico relataram a interferência da disponibilidade de água na fotossíntese, na condutância estomática e na transpiração da planta. Porém, as consequências da escassez hídrica em plantas deste gênero variam de acordo com a espécie, com o local, com o manejo do solo e da água, entre outros fatores.

Assim, faz-se necessária a condução de pesquisas direcionadas à seleção de espécies que apresentem maior resistência a condições de déficit hídrico em determinadas regiões, de maneira a proporcionar um melhor desenvolvimento e consequente elevada produtividade florestal, beneficiando tanto pequenos produtores como empresas florestais de grande porte. 


\section{REFERENCIAS}

[1] CARVALHO, R. M. M. A., SOARES, T. S., VALVERDE, S. R. Caracterização do setor florestal: uma abordagem comparativa com outros setores da economia. Ciência Florestal, Santa Maria, v. 15, n. 1, p. 105-118. 2005.

[2] CHAVES, M. M., FLEXAS, J., PINHEIRO, C. Photosynthesis under drought and salt stress: regulation mechanisms from whole plant to cell. Annals of Botany, 103: 551 - 560, 2009.

[3] CHOAT et al. Global convergence in the vulnerability of forests to drought. Nature, v. 491, 2012

[4] COOK R. L., BINKLEY, D., STAPE, J. L. Eucalyptus plantation effects on soil carbon after 20 years and three rotations in Brazil. Forest Ecology and Management, 92-98, 2016.

[5] COSTA, G. F., MARENCO, R. A. Fotossíntese, condutância estomática e potencial hídrico foliar em árvores jovens de andiroba (Carapa guianensis). Acta Amazonica, vol. 37(2), p. 229234, 2007.

[6] FERNANDES, E. T., CAIRO, P. A. R., NOVAES, A. B. D. Respostas fisiológicas de clones de eucalipto cultivados em casa de vegetação sob deficiência hídrica. Ciência Rural, Santa Maria, v. 45, n. 1, p. 29-34, 2015

[7] FERRAZ, T. M. Ecofisiologia de clones de eucalipto submetidos a restrição hídrica em condições de campo. Tese (Doutorado em Produção Vegetal). Universidade Estadual do Norte Fluminense, Campo dos Goytacazes, 2012.

[8] FLORES, T. B., ALVARES, C. A., SOUZA, V. C., STAPE, J. L. Eucalyptus no Brasil: zoneamento climático e guia para identificação. Piracicaba: IPEF, 2016. 448 p.

[9] GASPARATOS, A., DOLL, C.N.H., ESTEBAN, M., AHMED, A. Renewable energy and biodiversity: Implications for transitioning to a Green Economy. Renewable and Sustainable Energy Reviews 70, 161-184, 2017

[10] GENTIL, M. S. Transpiração e eficiência do uso da água em árvores clonais de Eucalyptus aos 4 anos em áreas com e sem irrigação em Eunápolis, Bahia. Dissertação (Mestrado em Recursos Florestais). Escola Superior de Agricultura "Luiz de Queiroz", Universidade de São Paulo, Piracicaba, 2010. $71 \mathrm{p}$.

[11] HÉROULT, A., LIN, Y., BOURNE, A., MEDLYN, B. E., ELLSWORTH, D. S. Optimal stomatal conductance in relation to photosynthesis in climatically contrasting Eucalyptus species under drought. Plant, Cell and Environment, v. 36, 262274, 2013

[12] IBÁ - Indústria Brasileira de árvores. Relatório anual 2016. Brasília/DF, 2016. 100 p. Disponível em:

<http://iba.org/images/shared/Biblioteca/IBA_Relato
rioAnual2016_.pdf> Acesso em: 19 abr. 2017.

[13] LARCHER, W. Ecofisiologia vegetal. 3 ed. São Carlos: Rima, 531p., 2004.

[14] LIMA, W.P. Impactos da cultura do eucalipto. Revista Silvicultura, n.64, p.32-8, 1995.

[15] LISAR, S. Y. S., MOTAFAKKERAZAD, R., HOSSAIN, M. M., RAHMAN, I. M. M. Water Stress in Plants: Causes, Effects and Responses. In: RAHMAN, I. M. M., HASEGAWA, H. Water stress. 2012

[16] LOPES, J. L. W., SAAD, J. C. C., GUERRINI, I. A., LOPES, C. F. Influência dos fatores bióticos e abióticos na sobrevivência de eucalipto em função do solo e do manejo hídrico de viveiro. Biotemas, v.22, n.2, p.29-38, 2009.

[17] LOPES, J. L., J. C. C., GUERRINI, SILVA, M. R., SAAD, J. C. C., LOPES, C. F. Estresse hídrico em plantio de Eucalyptus grandis vs. Eucalyptus urophylla, em função do solo, substrato e manejo hídrico de viveiro. Revista Árvore, v. 35, n. 1, p. 3139, 2011

[18] MARRICHE, A. H. C. Caracterização da capacidade fotossintética e da condutância estomática em sete clones comerciais de Eucalyptus e seu padrões de resposta ao déficit de pressão de vapor. Dissertação (Mestrado em Recursos Florestais). Universidade de São Paulo, Escola Superior de Agricultura "Luiz de Queiroz", Piracicaba, 2009. 104 p.

[19] MATOS, F. S., OLIVEIRA, P. R. C., GIL, J. L. R. A., SOUSA, P. V., GONÇALVES, G. A., SOUSA, M. P. B. L., SILVEIRA, P. S., SILVA, L. M. Eucalyptus urocan drought tolerance mechanisms. Afr. J. Agric. Res. Vol. 11(18), pp. 1617-1622, 2016

[20] McADAM, S. A. M., SUSSMILCH, F. C., BRODRIBB, T. J. Stomatal responses to vapour pressure deficit are regulated by high speed gene expression in angiosperms. Plant, Cell and Environment, v. 39, 485-491, 2016.

[21] NOGUEIRA, R. J. M. C., ARAÚJO, E. L., WILLADINO, L.G. CAVALCANTE, U. M. T. Estresses ambientais: danos e benefícios em plantas. Recife: UFRPE, Imprensa Universitária, 2005. 110 p.

[22] OSAKABE, Y., OSAKABE, K., SHINOZAKI, K., TRAN, L. S. P. Response of plants to water stress. Frontiers in Plant Science, v. 5, article 86, 2014.

[23] OTTO, M.S.G., VERGANI, A. R., GONÇALVES, A. N., VRECHI, A., SILVA, S. R., STAPE, J. L. Fotossíntese, condutância estomática e produtividade de clones de Eucalyptus sob diferentes condições edafoclimáticas. Revista Árvore, v. 37, n. 3, p. 431-439, 2013.

[24] PEREIRA, M. R. R., KLAR, A. E., SILVA, M. R., SOUZA, R. A., FONSECA, N. R. Comportamento fisiológico e morfológico de clones de Eucalyptus urogranis submetidos a diferentes níveis de água no solo. Irriga, v. 11, n. 4, p. 518-531, 2006 
[25] PIMENTEL, C. Respostas fisiológicas à falta d'água: limitação difusiva ou metabólica? In: NOGUEIRA, R.J.M.C.; ARAÚJO, E. DE L.; WILLADINO, L.G.; CAVALCANTE, U.M.T.; (Ed.). Estresses ambientais: danos e benefícios em plantas. Recife: UFRPE, Imprensa Universitária, p.13-21, 2005.

[26] SANTOS, R.F.; CARLESSO, R. Déficit hídrico e os processos morfológico e fisiológico das plantas. Revista Brasileira de Engenharia Agrícola e Ambiental, v.2, p.287-294, 1998.

[27] SCOLFORO, J. R. O mundo eucalipto: os fatos e mitos de sua cultura. Rio de Janeiro: Mar de Ideias, 2008.

[28] SENGUPTA, D.; KANNAN, M.; REDDY, A.R. A root proteomics-based insight reveals dynamic regulation of root proteins under progressive drought stress and recovery in Vignaradiata (L.) Wilczek. Planta, v.233, p.1111-1127, 2011.

[29] SILVA, W., SEDIYAMA, T., SILVA, A. A., CARDOSO, A. A. Índice de consumo e eficiência do uso da água em eucalipto, submetido a diferentes teores de água em convivência com braquiária. Floresta. Curitiba. 34 (3), 325-335. 2004.

[30] STAPE, J. L. BINKLEY, D., RYAN, M. G. Production and carbon allocation in a clonal Eucalyptus plantation with water and nutrient manipulations. For Ecol Manage 222:920-930. 2008 .

[31] TAIZ, L., ZEIGER, E., MØLLER, I. M., MURPHY, A. Fisiologia e desenvolvimento vegetal. 6. ed. Porto Alegre: Artmed, 2017. 888 p.

[32] TATAGIBA, S. D., PEZZOPANE, J. E. M., REIS,
E. F., DARDENGO, M. C. J. D., EFFGEN, T. A. M. Comportamento fisiológico de dois clones de Eucalyptus na época seca e chuvosa. Cerne, v. 13, n. 2, p. 149-159, 2007.

[33] VALDÉS, A. E., IRAR, S., MAJADA, J. P., RODRíGuEZ, A., FERNÁNDEZ, B., PAGÈS, M. Drought tolerance acquisition in Eucalyptus globulus (Labill.): A research on plant morphology, physiology and proteomics. Journal of proteomics, v. 79, p. 263-276, 2013.

[34] VELLINI, A. L. T. F., PAULA, N. F., ALVES, P. L. C. A., PAVANI, L. C., BONINE, C. A. V., SCARPINATI, E. A., PAULA, R. S. Respostas fisiológicas de diferentes clones de eucalipto sob diferentes regimes de irrigação. Árvore, Viçosa-MG, v. 32, n. 4, p. 651-663, 2008.

[35] XAVIER, T. M. T. Efeito da restrição hídrica sobre o crescimento de clones de eucalipto. 2010. 80 p. Dissertação (Mestrado em Produção Vegetal). Universidade do Espírito Santo, Alegre, 2010.

[36] ZHU, L. W., ZHAO, P., WANG, Q., NI, G. Y., NIU, J. F., ZHAO, X. H., ZHANG, Z. Z., ZHAO, P. Q., GAO, J. G., HUANG, Y. Q., GU, D. X., ZHANG, Z. F. Stomatal and hydraulic conductance and water use in a eucalyptplantation in Guangxi, southern China. Agricultural and Forest Meteorology, 202, 61-68, 2015. 


\section{Bapítulo 8}

\section{EVOLUCÃO DOS PLANOS DE MANEJOS FLORESTAIS APROVADOS E IMPLANTADOS NO ESTADO DE MATO GROSSO NO PERIODO DE 2000-2014}

\section{Alessandra Maria Filippin dos Passos}

\section{Aumeri Carlos Bampi}

Resumo: Dadas as contribuições das florestas em pé na redução das mudanças climáticas, conservação de espécies, ciclo hidrológico, qualidade dos solos, água e ar, a cobertura florestal nativa atesta o equilíbrio ecológico dos ecossistemas. Contudo, devido aos fatores de uso e ocupação da região amazônica pós 1970, a inserção de atividades econômicas, como a expansão da fronteira agrícola e pecuária e a extração madeireira de origem ilegal contribuíram para o avanço do desmatamento nos estados que compõem a Amazônia Legal, onde o estado de Mato Grosso vem apresentando taxas elevadas de degradação florestal. Deste modo, como forma de mitigar a exploração ilegal de madeira e consequentemente contribuir na redução do desmatamento, o estudo tem como objetivo demonstrar os esforços do estado de Mato Grosso referente a gestão florestal, evidenciando a implantação de manejos florestais, onde no período de 2000-2014 foram aprovados e implantados cerca de 2.174 planos de manejos buscando a extração sustentável dos recursos florestais associados a outras atividades extrativistas. A metodologia utilizada foi revisão de literatura e coleta de dados tendo como base SCIELO, Periódicos CAPES, GOOGLE Acadêmico e dados do IBAMA e SEMA-MT.

Palavras-chave: Desmatamento; Gestão florestal; Exploração ilegal; Amazônia Legal; Manejo florestal sustentável. 


\section{INTRODUÇÃO}

Considerando os benefícios das florestas, tendo em vista seus valores ambientais e econômicos, a manutenção das florestas é garantida por conta dos seus serviços fornecidos. Além do que, há outras alternativas de produção para a valorização das florestas: implantação de manejos florestais, fruticultura, energia, produtos não madeireiros, ecoturismo, bioprospecção, extrativismo e uso consciente público (RUDORFF et al., 2010).

Uma infinidade de espécies depende diretamente das florestas como fonte de abrigo, alimentação e ambiente para reprodução da biodiversidade. As florestas contribuem em relação a redução das mudanças climáticas através do sequestro de carbono atmosférico (aéreo e subterrâneo) e no solo, contribuindo com a redução do efeito estufa (SCANAVACA JUNIOR, 2011).

Contudo, o valor das florestas em pé não vem sendo respeitado. Na década de 1970, na região da Amazônia dado ao processo de uso e ocupação através da colonização atrelado a inserção de atividades econômicas em larga escala estava diretamente relacionado ao desmatamento na região. Fatores como a inserção de uma rede de estradas facilitando o acesso da capital nacional a novas áreas e as políticas desenvolvimentistas contribuíram para o processo de colonização e consequentemente de desmatamento na Amazônia (MORAN, 1981).

O processo de colonização no Estado de Mato Grosso, seguiu o mesmo modelo. Decorrente da inserção das políticas de colonização do estado e introdução de projetos que visavam a implantação de atividades econômicas, tais como: a exploração de madeira, atividades agropecuárias e a criação de usinas hidrelétricas e rodovias, geraram inúmeros conflitos entre os colonizadores $e$ as populações que já povoavam a região e contribuíram com o desmatamento no estado (ALENCAR, 2004).

A Amazônia brasileira é uma das regiões que apresentam maior potencial produtivo relacionado à extração de madeira tropical, ficando atrás somente da Malásia e Indonésia. A exploração madeireira, seu processamento e beneficiamento se destacam como uma das principais atividades econômicas desenvolvidas na região amazônica, com a mineração, a expansão agrícola e pecuária. (HUMMEL et al., 2010).

Devido aos elevados níveis de desmatamento e de extração ilegal da madeira esse potencial produtivo encontra-se ameaçado. Dados de ABIMCI (2014) destacam que entre 1988 e 2010 foram desmatados 37 milhões de hectares nos estados que compõem a Amazônia Legal, correspondendo em média 1,7 milhão de hectares ao ano.

A ilegalidade na exploração florestal é considerada um dos determinantes do desmatamento. O Brasil tem feito progressos lentos contra a exploração madeireira ilegal, onde a corrupção e a fraude permanecem no setor. Devido à gestão ineficiente dos órgãos, além da redução de recursos e incentivos a exploração legalizada (BLOCK et al, 2014).

A atuação da extração ilegal de madeira no país, em aspectos econômicos se sobressai devido aos produtos serem mais baratos havendo empecilho para as práticas dos manejos florestais. Com o setor madeireiro atuando de forma legal e sustentável, o modelo de desenvolvimento da região amazônica seria configurado para aproveitar os recursos naturais de forma inteligente $e$ que reduziria impactos ambientais da atividade madeireira, garantindo qualidade tanto para a floresta como para a sociedade (LERER e MARQUESINI, 2005).

Com 1,15 milhões de $\mathrm{km}^{2}$ de florestas aptas para a produção sustentável de bens e serviços florestais, o manejo de florestas naturais apresenta uma oportunidade para a promoção do desenvolvimento de base florestal e para a manutenção da qualidade ambiental e valor econômico da região (BANERJEE e ALAVALAPATI, 2010).

Visando $O$ potencial produtivo $e$ a conservação da área florestal, alternativas de exploração sustentáveis devem fomentadas. O manejo sustentável dos recursos florestais é uma alternativa que busca o desenvolvimento econômico de forma que não agrida significativamente a floresta e gerando benefícios sociais e ambientais para a região.

Segundo o Ministério do Meio Ambiente (2016), manejo florestal sustentável é a administração da floresta visando obter benefícios econômicos, socioambientais, levando em conta as limitações dos ecossistemas, ou seja, manejar áreas e extrair as espécies de acordo com as ordenações de 
um manejo sustentável e pensando no futuro da área e das espécies.

Os manejos florestais são apresentados como uma das principais formas de combater a ilegalidade do setor madeireiro, e consequentemente mitigar o desmatamento, formas de extração de madeira as quais minimizam os impactos dessa exploração, tanto das espécies das árvores quanto sobre os animais. Admitindo que a floresta se recupere e continue gerando benefícios. A prática de manejo florestal é considerada a melhor alternativa para aliar a conservação ambiental com o crescimento das comunidades rurais no interior da região da Amazônia Legal, tendo total importância na geração de renda e emprego (WELLESLEY, 2014).

Dada a importância das florestas, seus benefícios ambientais, sociais e potencial produtivo, a extração madeireira ilegal e o desmatamento gera impactos negativos ao meio ambiente. O Estado de Mato Grosso demonstra elevadas taxas de desmatamento, entretanto, segundo a literatura os manejos florestais são evidenciados como forma de extração sustentável das florestas e consequentemente de mitigar 0 desmatamento no estado. Deste modo, o estudo tem como objetivo demonstrar a evolução dos manejos como forma de atividade sustentável no estado de Mato Grosso no período de 2000-2014.

\section{METODOLOGIA}

O presente estudo foi desenvolvido a partir de uma revisão de literatura, onde foram considerados os principais autores nacionais e internacionais que dialogam a respeito do tema abordado. Foram selecionados artigos das seguintes base de dados: SCIELO, Periódicos CAPES, GOOGLE Acadêmico e dados do IBAMA e SEMA-MT.

\section{DETERMINANTES DO DESMATAMENTO E A ILEGALIDADE NO SETOR MADEIREIRO}

Segundo Geist \& Lambin (2002), as causas do desmatamento estão relacionadas as mudanças do uso solo que consequentemente geram impactos ao meio ambiente e a cobertura vegetal. As causas diretas do desmatamento são evidenciadas pelas seguintes categorias: expansão das áreas de pastagens e agrícolas, extração de madeira em tora e a melhoria de infraestrutura. Tais determinantes, definidos como causas subjacentes, estão diretamente relacionadas ao aumento da demanda de mercado por produtos que são originados a partir da mudança no uso do solo, associados a urbanização e o aumento populacional.

De acordo com INPE - Instituto Nacional de Pesquisas Espaciais (2002), o desmatamento é caracterizado como a conversão de áreas de floresta primária por atividades econômicas antropogênicas para o desenvolvimento de atividades agropecuárias detectadas por plataformas orbitais.

O processo de colonização da região Amazônica contribuiu para o desmatamento nos estados que a compõem. Entre os danos ambientais foram demonstrados conflitos violentos no processo de ocupação da região, dado ao avanço da fronteira agrícola e pecuária, em que os títulos de terras e os direitos de propriedade foram fatores que contribuíram gerando conflitos violentos na região (ALSTON et a., 1996).

Os principais determinantes que originaram o desmatamento no bioma amazônico estão ligados à expansão da agricultura, a falta de ordenamento territorial (legislação ambiental versus política fundiária), a pecuária e as obras de infraestrutura, em especial as rodovias e a extração de madeira nativa ilegal (LEMOS e SILVA, 2011).

Segundo Fearnside (2006), o bioma amazônico vem sendo devastado pela expansão do desmatamento, os serviços ambientais provenientes da floresta são altos, e quando a mesma é degradada há efeitos significativos em relação a manutenção da biodiversidade.

No estado do Mato Grosso, devido ao desenvolvimento e aos incentivos das colonizadoras, a inserção da atividade agropecuária e os garimpos, os efeitos dessa ocupação resultaram em grandes modificações na paisagem dos biomas (ANDERSON., et a/2005).

De acordo com os dados do Sistema de Alerta de Desmatamento (SAD) do Instituto do Homem e Meio Ambiente da Amazônia IMAZON (2017) demonstraram que o estado de Mato Grosso vem sendo um dos estados com maiores índices de desmatamento que aumentou cerca de $190 \%$ esses indicadores em 2016 comparado com o ano de 2015. 
Em estudo recente desenvolvido pelo ICV Instituto Centro de Vida (2018), com levantamento de dados a partir do PRODES Projeto de Monitoramento do Desmatamento na Amazônia Legal por Satélite, indicaram que os esforços desenvolvidos pelo estado de Mato Grosso tendo em vista o desenvolvimento sustentável estão sendo insuficientes. O estado de Mato Grosso segue em segunda posição em relação ao desmatamento na Amazônia. Segundo o estudo de agosto de 2017 a julho de 2018, foram desmatados mais $1.749 \mathrm{~km}^{2}$ de florestas, sendo essa taxa a maior detectada nos últimos 10 anos.

Gráfico 1- Desmatamento nos últimos dezoito anos em Mato Grosso.

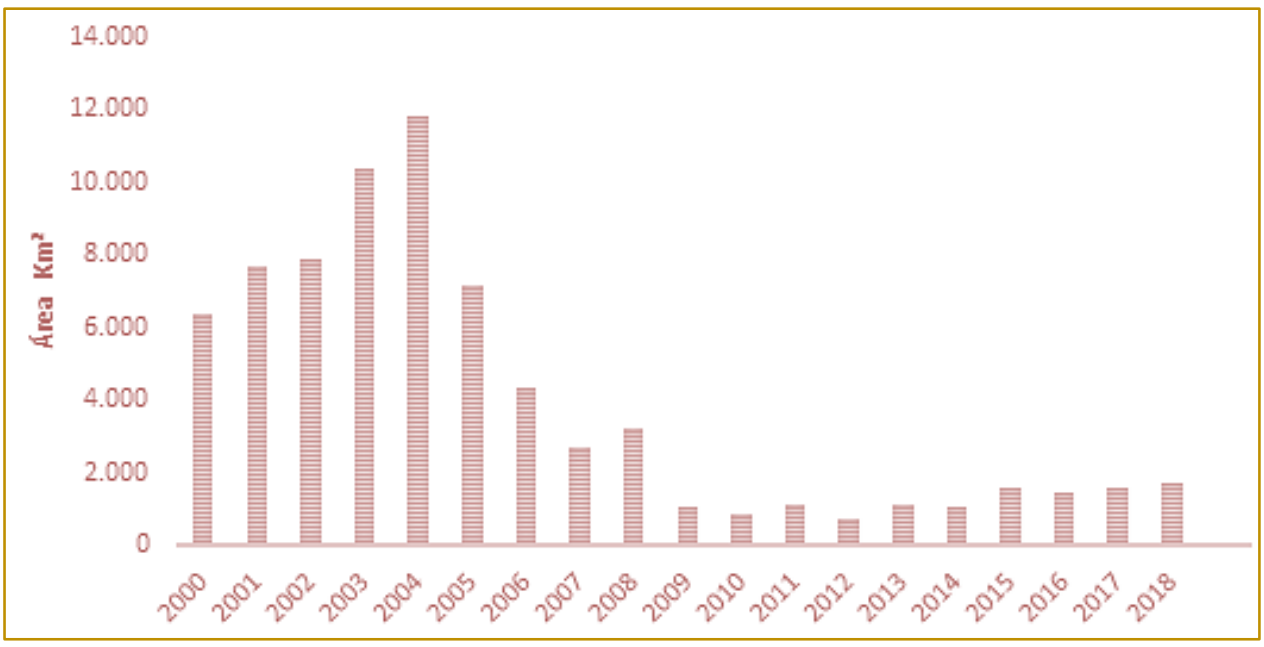

Fonte: Elaborado a partir de dados do INPE/PRODES, 2018.

No tocante da exploração madeireira de origem ilegal, a madeira oriunda da ilegalidade e seu comércio estão associados a graves problemas ambientais, econômicos e sociais. A extração ilegal aponta preocupações sobre o excesso de exploração e os déficits na implantação dos manejos dificultando os serviços ambientais. Como o registro ilegal é considerado rentável no curto prazo, muitas vezes está relacionado a corrupção impedindo o estado o direito de boa governança (LI et al., 2008).

Os produtores de origem madeireira que agem de acordo com as normas de legalidade exigidas no país para a produção, processamento, transporte e comercialização de madeira, não estão encontrando mercado para o seu produto, devido à discrepância de preços entre a madeira legal, onde os custos de produção são elevados. Entretanto, a produção ilegal, que sonega vários produtos possui custos reduzidos por não se adequarem às técnicas de manejo e operação (RICK, 2013).

O Estado de Mato Grosso apresenta representação significativa em relação a produtividade de madeira, em 2009, mais de 1,8 milhões de $\mathrm{m}^{3}$ foram extraídos gerando empregos diretos e indiretos relacionados a indústria madeireira (PEREIRA et al, 2010). Contudo, essa representatividade do setor está associada a problemática da extração madeireira ilegal. Segundo o ICV (2018), quase metade da área de floresta explorada no estado foi de origem ilegal no período de 2012 até 2016 e de acordo com mapeamento realizado em 2014 até 2016, 49\% da área de exploração madeireira no estado foi caracterizada como ilegal.

\section{IMPORTÂNCIA DOS MANEJOS FLORESTAIS E OS ESFORÇOS DESENVOLVIDOS PELO ESTADO DE MATO GROSO}

Uma das principais formas de combater a ilegalidade do setor madeireiro, e mitigar o desmatamento, é dada pela implantação de manejos florestais sustentáveis. A prática de manejo florestal é considerada a melhor alternativa para aliar a conservação ambiental com o crescimento das comunidades no interior da região da Amazônia Legal, tendo 
total importância na geração de emprego e renda (WELLESLEY, 2014).

Os manejos florestais proporcionam relações concretas entre aspectos econômicos, socioambientais e desenvolvimento regional, ressaltando o pensamento do uso das florestas de forma equitativa. Visando tais aspectos, programas de manejos florestais estão sendo implantados em todo o planeta. Organizações governamentais e nãogovernamentais, comunidades e associações buscam formas de extração florestal e sustentável através dos manejos (COUTO \& ALVES, 2003).

Também é citado como importante ferramenta fornecendo participação na assessoria florestal dos devidos órgãos e as atividades econômicas relacionadas à silvicultura. Deste modo, as ações florestais possuem efeitos duradouros em níveis econômicos, ecológicos e socioculturais. O objetivo do planejamento florestal é fornecer informações aos tomadores de decisões para que sejam cumpridas de forma eficiente os critérios estabelecidos para uma gestão sustentável dos recursos florestais (KANGAS \& KANGAS, 2005).

Os manejos florestais estavam inseridos no Código Florestal de 1965, como política ambiental para a exploração madeireira na região amazônica, onde no artigo 15, mencionava-se que estava proibida a exploração sob forma empírica das florestas primitivas na bacia amazônica, que só poderiam ser exploradas a partir da condução do plano de manejo dentro de suas normas técnicas estabelecidas por ato do Poder Público dentro de um ano. Entretanto, somente em 1995 o Instituto Brasileiro de Meio Ambiente e dos Recursos Renováveis (IBAMA) especificou o manejo florestal na portaria 48 (GARRIDO FILHA, 2002).

Buscando a legalidade na extração florestal, o estado de Mato Grosso vem desenvolvendo esforços em relação a implantação de planos de manejos florestais, onde o estado apresentou 2.183 manejos aprovados e implantados no período de 2000-2014.

Gráfico 1- Evolução dos Planos de Manejos Florestais implantados em Mato Grosso

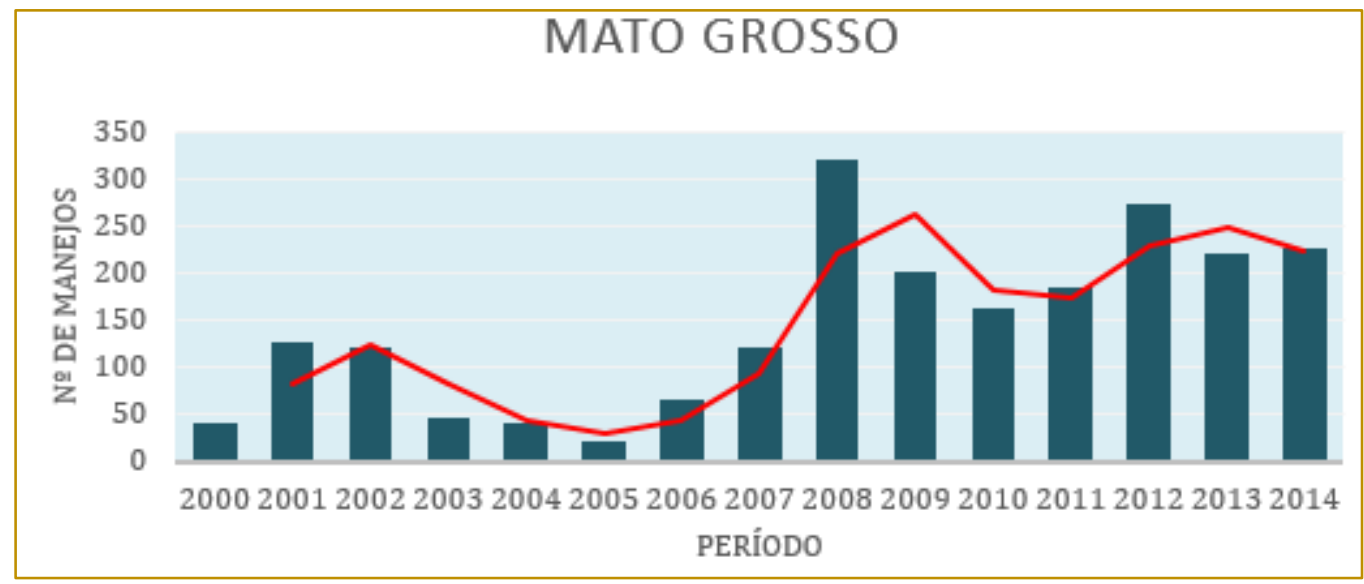

Fonte: Elaborado a partir de dados do IBAMA/SEMA-MT, 2015.

Segundo dados fornecidos pela Secretaria de Estado de Meio Ambiente (SEMA-MT), e pelo Instituto Brasileiro do Meio Ambiente e dos Recursos Naturais Renováveis (IBAMA), o período de 2000-2006 foi considerado discreto em relação a inserção dos planos de manejos, fator esse atrelado a falta de investimentos e não cumprimento da legislação florestal. Já o ano de 2008 foi o mais significativo onde foram aprovados e implantados 322 planos de manejos, representando $15 \%$ do total de manejos florestais implantados no estado.
Contudo, em 2009 a inserção de planos de manejos florestais reduziu (-39\%), segundo o ICV essa diminuição se deu pela burocracia e retardamento no licenciamento ambiental nas áreas de manejo no estado, onde por consequência, a oferta de madeira legal originada dos manejos sustentáveis diminuiu. O ano de 2010, também demonstrou uma redução no número de manejos implantados (-20\%), reduzindo também a exploração de madeira nativa.

No entanto, o ano de 2012 apresentou a segunda maior significância dado o período 
analisado, representando $13 \%$ do total de manejos implantados. Os anos sequentes de 2013 e 2014, mantiveram-se elevados e apresentaram pouca variação.

Logo, pode ser visto que por conta da burocracia e a falta de incentivos impedem a constante aprovação e implantação dos planos de manejos florestais, levando a oscilação na quantidade anual abrindo espaço para a extração ilegal de madeira, onde a mesma é considerada menos custosa e burocrática em curto prazo.

\section{CONSIDERAÇÕES FINAIS}

De acordo com a evolução dos planos de manejos no Estado de Mato Grosso, como

\section{REFERÊNCIAS}

[1] Abimci - Associação Brasileira da Indústria de Madeira Processada e Indústrial Estudo setorial. Disponível em: http:// http://www.abimci.com.br/estudos-setoriais/.

[2] Alencar, A. Belém: Instituto de Pesquisa Ambiental da Amazônia, 2004

[3] Alston, L. J., Libecap, G. D. \& Schneider, R. (1996), Violence and the assignment of property rights on two brazilian frontiers, in 'The Political Economy of Conflict and Appropriation', Cambridge University Press, 1996.

[4] Anderson, L. O., Shimabukuro, Y. E., Lima, A., \& Medeiros, J. S (2005). Mapeamento da cobertura da terra do Estado do Mato Grosso através da utilização de dados Multitemporais do Sensor Modis. Geografia, 30(12), 2005.

[5] Banerjee, O.; Alavalapati J. "Illicit exploitation of natural resources: The forest concessions in Brazil." Journal of Policy Modeling 32.4: 488-504, 2010.

[6] Block, S., Galabuzi, G. E., \& Weiss, A. (2014). The colour coded labour market by the numbers. Toronto, ON: Wellesley Institute, 2009.

[7] Couto, E. P.; Alves A. M. S. O manejo florestal no Brasil. 2003.

[8] Fearnside, P. M. (2006). Desmatamento na Amazônia: dinâmica, impactos e controle. Acta Amazonica, 36(3), 395-400, 2006.

[9] Garrido Filha, I. Manejo florestal: questões econômico-financeiras e ambientais. Estudos Avançados 16.45 p. 91-106, 2002.

[10] Hummel, A. C., Alves, M. D. S., Pereira, D., Veríssimo, A., \& Santos, D. A atividade madeireira forma de extração sustentável dos recursos florestais e mitigar o desmatamento, o estado aprovou cerca de 2.174 manejos florestais de 2000 até 2014, onde os anos de 2008 e 2012 foram os mais significativos, representando 15 e $13 \%$, respectivamente.

Além da importância dos manejos florestais em relação a gestão da floresta, outro fator relevante são os benefícios socioeconômicos e ambientais que os manejos proporcionam, abrindo espaço para dialogar com outras atividades florestais como 0 extrativismo utilizando os conhecimentos empíricos das populações locais na elaboração do projeto de manejo e na prática do mesmo fortalecendo a participação local no processo fomentando benefícios sociais econômicos e ecológicos.

na Amazônia brasileira: produção, receita e mercados. Belém: Imazon, 2010.

[11] Ibama, Instituto Brasileiro do Meio Ambiente e dos Recursos Naturais Renováveis. Disponível em: <http://www.ibama.gov.br/>. Acesso em abril de 2018.

[12] Icv, Instituto Centro de Vida. Disponível em:<http://www.icv.org.br/>. Acesso em junho de 2018.

[13] Instituto Nacional de Pesquisas Espaciais (INPE) 2002. Monitoring of the Brazilian Amazon Forest by Satellite 2000-2001. Brasília, INPE, FUNCATE.

[14] Kangas, J., \& Kangas, A. (2005). Multiple criteria decision support in forest management The approach, methods applied, and experiences gained. Forest Ecology and Management, 207(1-2 SPEC. ISS.), 133-143. Disponível em: <https://doi.org/10.1016/j.foreco.2004.10.023>. Acesso em março de 2018.

[15] Lemos, A. L. F.; Silva, J. A. Desmatamento na Amazônia Legal: evolução, causas, monitoramento e possibilidades de mitigação através do Fundo Amazônia. Floresta e Ambiente 18.1 p. 98-108, 2011.

[16] Lerer, R., Marquesini, M. Tolerância zero: chega de madeira ilegal. Greenpeace Brasil, 2005.

[17] Ministério do Meio Ambiente, 2016. Disponível

em: <http://www.mma.gov.br/florestas/manejo-florestalsustent\%C3\%A1vel>. Acesso em fevereiro de 2018.

[18] Rudorff, B. F. T.; Aguiar, D. A.; Silva, W. F.; Sugawara, L. M.; Moreira, M. A. Studies on the Rapid Expansion of Sugarcane for Ethanol 
Production in São Paulo State (Brazil) Using Lansat Data. Remote Sensing, 2010.

[19] Sad (Sistema de Alerta de Desmatamento) - IMAZON (Instituto do Homem e Meio Ambiente da Amazônia). Disponível em: <http://amazonia.org.br/2016/05/desmatamento-daamazonia-legal-aumenta-190-em-mt-diz-imazon/> Acesso em: abril de 2018.

[20] Sema-MT, Secretaria de Estado de Meio Ambiente. Disponível em: <http://www.sema.mt.gov.br/>. Acesso em maio de 2018.

[21] Wesllesley, L. Exploração Florestal Ilegal e Comércio Conexo A Resposta no Brasil. Energia, Meio Ambiente e Recursos, 2014.
[22] Geist, H. J.; Lambin, E. F. Proximate causes and underlying driving forces of tropical deforestation. P. 143-150, 2002.

[23] Scanavaca Junior, L. "A importância da floresta para o meio ambiente." Embrapa Meio Ambiente-Artigo de divulgação na mídia (INFOTECA-E) (2011).

[24] Moran, E. F.1981. Developing the Amazon. Indiana University Press, Bloomington. 292p.

[25] LI, R., Buongiorno, J., Turner, J. A., Zhu, S., \& Prestemon, J. (2008). Long-term effects of eliminating illegal logging on the world forest industries, trade, and inventory. Forest Policy and Economics, 10(7-8), 480-490.

[26] Pereira, D., Santos, D., Vedoveto, M., Guimarães, J., \& Veríssimo, A. (2010). Fatos Florestais. Imazon, Belém, PA. 


\section{Bapítulo 9}

\section{USO DE EXTRATOS NATURAIS COMO INIBIDORES DE CORROSÃO PARA O AÇO AISI 304}

\section{Juliana Araujo da Silva \\ Graziella Sarpe Capo \\ Maurício Masaru de Souza Ribeiro \\ Maurício Marques Pinto da Silva}

Resumo : O trabalho baseia-se em estudar o efeito de compostos não tóxicos ao meio ambiente e provenientes de recursos naturais renováveis, utilizando-os como inibidores de corrosão ambientalmente seguros para o aço AISI 304 em meio de $\mathrm{HCl}$ 0,1 mol. $\mathrm{L}^{-1}$. Os extratos aquosos e etanólicos das folhas desidratadas e moídas de llex paraguariensis e Camellia sinensis, que foram obtidas na Zona Cerealista da cidade de São Paulo, foram previamente analisadas granulometricamente e submetidas à agitação magnética. A avaliação da proteção à corrosão foi feita com a imersão de placas de aço em alíquotas dos extratos aquosos e etanólicos durante 30 minutos. O potencial de corrosão (Ecorr) foi determinado utilizando eletrodo de calomelano saturado como referência. Na ausência de inibidores (ensaio preliminar), o Ecorr foi igual a - $158 \mathrm{mV} / E C S$. O Ecorr do extrato aquosos de Ilex paraguariensis foi de - $138 \mathrm{mV} / \mathrm{ECS}$ e o de Camellia sinensis $-149 \mathrm{mV} / \mathrm{ECS}$. Os extratos etanólicos de Ilex paraguariensis e Camellia sinensis apresentaram Ecorr iguais a -58 e -143 mV/ECS, respectivamente. Apenas o extrato etanólico da /lex paraguariensis apresentou resultado significativo na inibição do processo corrosivo no metal em estudo; desta forma, este apresenta potencial uso como inibidor de corrosão do aço AISI 304.

Palavras-chave: Anticorrosivos; Inibidores verdes; Camellia sinensis; Ilex paraguariensis. 


\section{INTRODUÇÃO}

A corrosão é definida como um fenômeno natural comum em diversos tipos de metais, sendo o resultado de reações químicas ou eletroquímicas entre o metal e o ambiente, podendo estar relacionado à esforços mecânicos, causando a degradação e até a perda do metal. Para cada tipo de metal existem inibidores distintos, que devem ser selecionados anteriormente. Essa prática é bastante comum na indústria para reduzir os gastos com manutenção de elementos metálicos que sofrem com a corrosão (Távora, 2007).

Três métodos de inibição de corrosão são os mais comuns: o método eletroquímico, o de proteção anódica e catódica (revestimentos orgânicos) e; a inibição da reação catódica ou anódica utilizando agentes que reagem com os produtos da corrosão (costa, 2017). A maioria dos agentes inibidores utilizados em indústrias são compostos orgânicos (rocha e gomes, 2017).

Os inibidores de corrosão químicos podem ser potencialmente poluidores; por este motivo, atuais estudos estão pesquisando a eficiência de extratos de plantas ou materiais biodegradáveis para realizar esta função, podendo levar à formação de filmes na superfície do metal, devido à presença de compostos como alcaloides, flavonoides, entre outros (Rocha e Gomes, 2017).

Nesse contexto, diversos estudos têm sido feitos sobre o potencial de extratos naturais como inibidores verdes contra a corrosão de metais (Teixeira et al., 2015; Nabel et al., 2013; Loto et al., 2011). A substituição dos compostos orgânicos por outros de origem natural e renovável, como extratos naturais, podem contribuir para a diminuição da degradação ambiental.

A erva mate (/lex paraguariensis) é uma espécie vegetal nativa das regiões subtropicais e temperadas da América do Sul; o extrato desta erva e de outras folhas pode ser utilizado como inibidor de corrosão para aço inoxidável em soluções ácidas (Santos et al., 2017).

Outro exemplo de extrato de folhas que pode ser utilizado na inibição da corrosão, é da Camellia sinensis, que dá origem aos chás preto e verde; por conter polifenóis monoméricos e catequinas, inibem a corrosão em algumas condições (Teixeira et al., 2015).
Essa pesquisa objetivou analisar a aplicação de extratos naturais na inibição de corrosão do aço AISI 304 em meio ácido.

\section{METODOLOGIA}

Os inibidores verdes foram preparados obtendo-se extratos aquosos e etanólicos das folhas desidratadas e moídas com auxílio de almofariz e pistilo de llex paraguariensis e Camellia sinensis, que foram obtidas na Zona Cerealista da cidade de São Paulo.

Utilizaram-se $10 \mathrm{~g}$ do material previamente analisados granulometricamente com peneira de 65 Tyler com abertura de $212 \mu \mathrm{m}$, submetidos à agitação magnética (com 100 $\mathrm{mL}$ de água fervente por 60 minutos) e filtradas em papel filtro. Outra extração sob agitação foi realizada utilizando etanol (grau P.A.) como solvente de extração em temperatura ambiente.

As placas de aço inoxidável austenítico tipo ABNT $304(680 \times 120 \times 1 \mathrm{~mm})$ foram lixadas manualmente (320, 400 e 600 mesh), até a remoção de resíduos de sujeira acumulados no local, lavadas com água destilada e secas em corrente de ar quente, conforme a norma ASTM - A967- 05.

A avaliação da proteção à corrosão foi por meio da imersão das placas em alíquotas dos inibidores, durante 30 minutos em meio natural, à temperatura ambiente. Em seguida, as placas foram expostas em meio corrosivo por um período de 60 minutos, com a imersão em solução de ácido clorídrico $(\mathrm{HCl} \quad 0,10$ $\left.\mathrm{mol} \cdot \mathrm{L}^{-1}\right)$.

A variável resposta foi a diferença de potencial entre a placa e a solução (Potencial de circuito aberto - Eca), utilizando eletrodo de calomelano saturado (ECS) como referência na determinação do potencial de corrosão (Ecorr), sendo determinada no seguinte padrão: a cada minuto nos primeiros 10 minutos; a cada 2 minutos até completar 20 minutos e; a cada 5 minutos até o período de 60 minutos, tempo suficiente para determinação do valor de Ecorr. Os dados foram obtidos em duplicata. Um ensaio preliminar foi realizado, submetendo as placas diretamente ao meio corrosivo $(\mathrm{HCl})$ sem tratamento com os extratos naturais.

Para analisar os efeitos dos extratos de lex paraguariensis e Camellia sinensis como inibidores de corrosão, trataram-se 
estatisticamente os dados de Ecorr utilizandose o teste t pareado.

\section{RESULTADOS E DISCUSSÃO}

As placas de aço AISI 304 na presença de inibidores apresentaram valores de Ecorr menos negativos, mais próximos de zero, em relação ao ensaio preliminar. A Tabela 1 exibe os valores de Ecorr obtidos para a duplicata dos sistemas em ausência e em presença de inibidores verdes de corrosão após 60 minutos.

Tabela 1. Valores médios de potencial de circuito aberto (Eca (mV/ECS) obtidos na presença e ausência de extratos naturais (Et: etanólico e Aq: aquoso) e no ensaio preliminar ( $\mathrm{HCl} \mathrm{0,10} \mathrm{mol} \cdot \mathrm{L}^{-1}$ ) nas diferentes faixas de tempo analisadas.

\begin{tabular}{|c|c|c|c|c|c|}
\hline \multirow[t]{2}{*}{ Tempo (min.) } & \multirow[t]{2}{*}{$\mathrm{HCl}$} & \multicolumn{2}{|c|}{$\begin{array}{c}\text { Ilex } \\
\text { paraguariensis }\end{array}$} & \multicolumn{2}{|c|}{$\begin{array}{l}\text { Camellia } \\
\text { sinensis }\end{array}$} \\
\hline & & Et & $\mathrm{Aq}$ & Et & $\mathrm{Aq}$ \\
\hline $0-10$ & $\begin{array}{l}-199 \\
\pm 19 \\
\end{array}$ & $\begin{array}{c}-44 \pm \\
4\end{array}$ & $\begin{array}{c}-171 \\
\pm 4 \\
\end{array}$ & $\begin{array}{l}-191 \\
\pm 23\end{array}$ & $\begin{array}{r}194 \\
\pm 17\end{array}$ \\
\hline $12-20$ & $\begin{array}{c}-176 \\
\pm 2 \\
\end{array}$ & $\begin{array}{c}-60 \pm \\
9\end{array}$ & $\begin{array}{c}-158 \\
\pm 3 \\
\end{array}$ & $\begin{array}{c}-164 \\
\pm 3 \\
\end{array}$ & $\begin{array}{c}-170 \\
\pm 3 \\
\end{array}$ \\
\hline $25-40$ & $\begin{array}{c}-169 \\
\pm 3\end{array}$ & $\begin{array}{c}-68 \pm \\
3\end{array}$ & $\begin{array}{c}-148 \\
\pm 4\end{array}$ & $\begin{array}{c}-154 \\
\pm 4\end{array}$ & $\begin{array}{c}-160 \\
\pm 3\end{array}$ \\
\hline $45-60$ & $\begin{array}{r}-161 \\
\pm 2 \\
\end{array}$ & $\begin{array}{c}-57 \pm \\
7\end{array}$ & $\begin{array}{c}-140 \\
\pm 2\end{array}$ & $\begin{array}{c}-145 \\
\pm 2\end{array}$ & $\begin{array}{c}-152 \\
\pm 3\end{array}$ \\
\hline$V^{*}$ & $\begin{array}{c}-158 \\
\pm 1\end{array}$ & $\begin{array}{c}-58 \pm \\
4\end{array}$ & $\begin{array}{c}-138 \\
\pm 7\end{array}$ & $\begin{array}{c}-143 \\
\pm 3\end{array}$ & $\begin{array}{c}-149 \\
\pm 2\end{array}$ \\
\hline
\end{tabular}

*Valor de Ecorr. O HCl foi utilizado na concentração 0,10 mol L ${ }^{-} 1$.

O ensaio preliminar apresentou Ecorr médio igual a $-158 \mathrm{mV} / \mathrm{ECS}$ em um tempo de 60 minutos. Já em presença de extrato aquoso de Ilex paraguariensis o Ecorr foi de -138 e $149 \mathrm{mV} / \mathrm{ECS}$ para o extrato aquoso de Camellia sinensis. Os extratos etanólicos de Ilex paraguariensis e Camellia sinensis, neste mesmo tempo, apresentaram valores de potencial de corrosão de -58 e -143 mV/ECS, respectivamente.

O valor menos negativo indica uma menor atividade corrosiva do aço: Carvalho (2015) também notou o comportamento de deslocamento do Eca para valores mais positivos para o aço carbono 1020 tratado com extrato natural.

As moléculas dos inibidores geram um filme protetor, adsorvendo na superfície metálica, o que leva à capacidade protetora de corrosão. Esta adsorção e eficiência estão relacionadas com a estrutura química e propriedades físico-químicas do composto como: o grupo funcional, estrutura eletrônica da molécula, tamanho e comprimento da molécula, o tipo de ligação química e sua força, a capacidade de interligação, solubilidade ao meio, entre outros (NABEL et al., 2013).
Os compostos responsáveis pela ação antioxidante no Camellia sinensis e na llex paraguariensis, de acordo com Saito (2007), são os fenólicos: as folhas em base seca apresentam cerca de 10 a $20 \%$ destes compostos. Dentre outras características, os compostos fenólicos são responsáveis pela coloração das folhas e a capacidade de neutralizar radicais livres de oxigênio: estes compostos podem desempenhar atividades antioxidantes devido as suas características estruturais, como a afinidade com metais (Loto et al, 2011).

Esta afinidade se dá devido a ação como agente quelante dos compostos naturais, onde é realizada a ligação com o íon metálico em dois locais da molécula no grupo ortodifenólico dos dois aneis benzênicos de sua estrutura: este mecanismo da adsorção do filme protetor na superfície metálica pode ser representado por equações (Rocha et al., 2014 e Khan et al., 2015).

Segundo as equações 1 e 2 , a molécula de inibidor que está presente na solução (Inibidor $\left._{(s o l)}\right)$, substitui a molécula de água adsorvida na superfície metálica $\left(\mathrm{H}_{2} \mathrm{O}_{(\text {ads })}\right)$, não necessariamente obedecendo a proporção de 1:1. Para esta equação: (sol) significa molécula dissolvida na solução, (ads) 
moléculas adsorvidas na superfície, e " $x$ " 0 número de moléculas de água que serão substituídas (Khan et al., 2015).

Depois da primeira etapa de substituição das moléculas de água adsorvidas, o inibidor pode se combinar com os íons metálicos $\left(\mathrm{M}^{2+}\right)$, que são gerados devido ao processo de oxidação, formando um complexo.

$$
\begin{aligned}
\text { Inibidor }_{(\text {sol })}+\mathrm{xH}_{2} \mathrm{O} & \rightarrow \text { Inibidor }_{(\mathrm{ads})}+\mathrm{H}_{2} \mathrm{O}_{(\text {sol })} \\
\mathrm{M}^{2+}+\text { Inibidor }_{(\mathrm{ads})} & \rightarrow[\mathrm{M}-\text { Inibidor }]_{(\mathrm{ads})}^{+2}
\end{aligned}
$$

Este mecanismo é ilustrado graficamente (Figura 1) onde, foi possível observar a tendência de comportamento da placa metálica em estudo, quando atacada pelo meio corrosivo em presença e em ausência dos extratos naturais. A curva de Eca para o extrato etanólico de llex paraguariensis foi a única, que mostrou comportamento inibitório de corrosão, as curvas de Eca dos demais extratos foram semelhantes ao ensaio preliminar, sendo assim, não apresentaram efeito inibitório.

No contato inicial do metal com o meio corrosivo, a tendência do valor de Eca é subir abruptamente devido à busca do equilíbrio, nos 10 primeiros minutos do ensaio preliminar, os valores de Eca variaram de forma não linear. Este comportamento pode indicar o ataque inicial da solução de ácido clorídrico à placa de aço já que, segundo Tussolini et al. (2007), o aço tipo ABNT 304 não resiste a ácidos como o clorídrico diluído, sendo necessária a adição de inibidores de corrosão para que o mesmo não degrade.

Na placa tratada com inibidores naturais, nos mesmos dez primeiros minutos, os valores de
Eca se apresentaram menos negativos do que o ensaio preliminar. Porém, ocorreu a oxidação do metal, indicado por valores de Eca mais negativos; conforme liberaram-se os íns provenientes da oxidação, estes reagiram com a molécula do inibidor formando o complexo que foi responsável pela eficiência inibitória da corrosão (valor de Ecorr estabilizado).

Assim, pode-se inferir que o efeito de adsorção das moléculas orgânicas (compostos polifenóis ou heterocíclicos) presentes no extrato de Camellia sinensis e llex paraguariensis provavelmente contribuíram na preservação do aço, com a formação de uma película protetora. (Rocha e Gomes, 2017)

Segundo Singh (2011), em seu estudo do efeito inibitório de corrosão por compostos naturais, a eficiência na redução no potencial de corrosão na superfície metálica de aço carbono atacada por ácido clorídrico, também foi atribuída a formação de um filme protetor do extrato de Pongamia pinnata.

Figura 1 - Comparação dos valores de Eca no efeito inibitório de extratos naturais na corrosão do aço AISI 304 em meio de HCl.

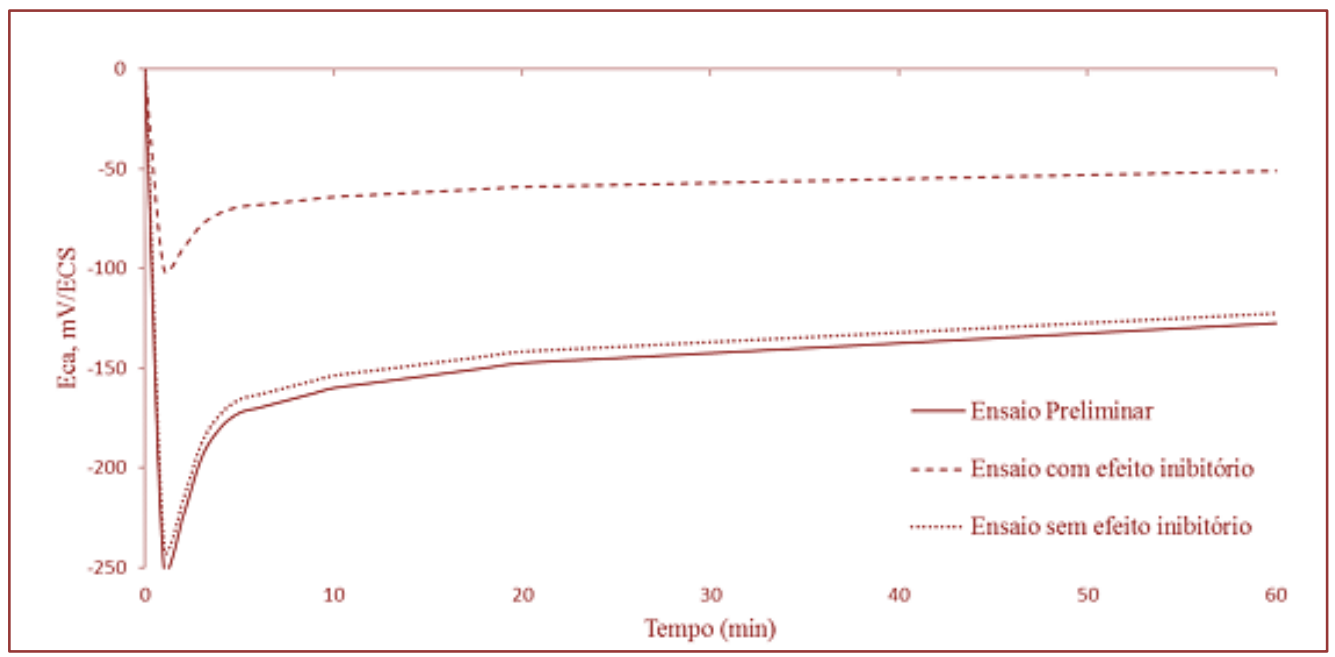


Então, pôde-se testar que as diferenças (analisadas pelo teste-t pareado) entre 0 ensaio preliminar e com inibidores etanoicos são diferentes de zero, em que o extrato de Ilex paraguariensis apresentou valor $86 \%$ menor e o extrato de Camellia sinensis 7\%, ou seja, a proteção contra a corrosão se mostrou mais eficiente em soluções etanólicas, para o extrato de llex paraguariensis devido à ação polar e apolar do etanol; para o extrato de Camellia sinensis o efeito inibitório não se mostrou tão significativo.

Inicialmente a parte apolar do solvente removeu óleos, graxas, pigmentos e esteróis, que podem estar presentes nos extratos naturais, o que facilitou a extração dos compostos de interesse, onde a parte polar extraiu as substâncias polifenólicas, como os flavonoides. As soluções aquosas de ambos os extratos naturais em estudo, teriam melhor eficácia, se antes fosse realizada uma etapa de extração de impurezas (moléculas não importantes para o presente estudo) através de um solvente apolar (Rocha et al., 2014).

\section{REFERÊNCIAS}

[1] ASTM A967-05. 2005. Standard Specification for Chemical Passivation Treatments for

Stainless Steel Parts, ASTM International, West Con shohocken, PA. DOI: http://doi.org/10.1520/A096705

[2] Carvalho, R.H.R. 2015. Extração supercrítica de óleo de Sesamum indicum L. e aplicação como inibidor de corrosão em aço AISI 1020 através de sistemas microemulsionados. Tese de Doutorado em Engenharia Química, Centro de Tecnologia, Universidade Federal do Rio Grande do Norte, Natal, Rio Grande do Norte. 146p

https://repositorio.ufrn.br/jspui/handle/123456789/2 2444

[3] Costa, S.N. 2017. Compostos derivados do Imidazol como inibidores da corrosão do aço carbono em meio ácido. Dissertação de Mestrado, Programa de Pós Graduação em Engenharia e Ciência de Materiais, Centro de Tecnologia, Universidade Federal do Ceará, Fortaleza, Ceará. $71 \mathrm{p}$.

http://www.repositorio.ufc.br/handle/riufc/22805

[4] Khan, G.; Kazi, S.N.; Basirun, W.; Binti, H.; Ali, M.; Faraj, F.; Mustafa, K.G. 2015. Application of Natural Product Extracts as Green Corrosion Inhibitors for Metals and Alloys in Acid Pickling Processes-A review. International Journal of Electrochemical Science, 10(8): 6120-6134. http://www.electrochemsci.org/list15.htm\#issue8

\section{CONCLUSÕES}

Dentre os extratos analisados, o extrato etanólico de Ilex paraguariensis., apresentou valor significativamente melhor que o ensaio preliminar, para a amenização do efeito corrosivo sobre a placa do aço AISI 304 nas condições experimentais avaliadas.

Para validação do potencial uso de Camellia sinensis e llex paraguariensis como inibidores de corrosão para o aço AISI 304, deve-se quantificar a concentração de polifenóis nos extratos das ervas nos diferentes métodos de extração, além de realizar testes com outros meios corrosivos, também alterando o tempo de imersão da placa nos extratos naturais.

[5] Loto, C.; Loto, R.P.P.; Popoola, A.P.I. 2011. Inhibition Effect of Extracts of Carica Papaya and Camellia Sinensis Leaves on the Corrosion of Duplex $\left(\begin{array}{ll}\alpha & \beta\end{array}\right)$ Brass in $1 \mathrm{M}$ Nitric acid. International Journal of Electrochemical Science, 6( 1): 4900-4914.

http://www.electrochemsci.org/list11.htm

[6] Nabel A.; Negm, M.A.; Yousef, S.M.T. 2013. Impact of Synthesized and Natural Compounds in Corrosion Inhibition of Carbon Steel and Aluminium in Acidic Media. Recent Patents on Corrosion Science (Discontinued), 3(1):5 8 -

68. DOI: https://doi.org/10.2174/221068391130301 0007

[7] Rocha, J.C., Gomes, J.A.C.P. 2017. Inibidores de corrosão naturais - Proposta de obtenção de produtos ecológicos de baixo custo a partir de resíduos industriais. Revista Matéria, Suplemento,22(jan):e-

11927. DOI: http://dx.doi.org/10.1590/s1517707620170005.0263

[8] Rocha, J. C., Gomes, J. A. C. P.; D'Elia, E.2014. Aqueous extracts of mango and orange peel as green inhibitors for carbon steel in hydrochloric acid solution. Materials Research, 17(6): 1581

1587. https://dx.doi.org/10.1590/1516-1439.285014

[9] Santos, M,; Almeida, Thassia Felix de, Cotting, Fernando, Aoki, Idalina Vieira, Melo, Hercílio Gomes de, \& Capelossi, Vera Rosa. 2017. 
Evaluation of Castor Bark Powder as a Corrosion Inhibitor for Carbon Steel in Acidic Media. Materials Research, 20(2): 492-505. DOI: http://dx.doi.org/10.1590/1980-5373-mr-2016-0963

[10] Santos, A. M.; Almeida, T. F.; Cotting, F,; Aoki, I.V.; Melo, H.G.; Capelossi, V.R. (2017). Evaluation of Castor Bark Powder as a Corrosion Inhibitor for Carbon Steel in Acidic Media. Materials Research, 20(2), 492-505. DOI http://dx.doi.org/10.1590/1980-5373-mr-2016-0963

[11] Singh, A., Ahamad, I., Singh, V.K. 2011. Inhibition effect of environmentally benign Karanj (Pongamia pinnata) seed extract on corrosion of mild steel in hydrochloric acid solution. Journal Solid State Electrochem, 15(6): 1087 - $1097 . \quad$ DOI: https://doi.org/10.1007/s10008-010-1172-z

[12] Távora, M. P. 2007. Avaliação do efeito de particulados sólidos na eficiência de um inibidor de corrosão recomendado para meios salinos com CO2. Dissertação de Mestrado, Programa de Pós
Graduação em Ciência e Engenharia de Materiais, Centro de Ciências Exatas e da Terra, Universidade Federal do Rio Grande do Norte, Natal, Rio Grande do Norte. 128p. https://repositorio.ufrn.br/jspui/handle/123456789/1 2858

[13] Teixeira, V. M.; dos Santos, E. C.; Rezende, M. J. C.; D'Elia, E. 2015. Estudo da ação Inibidora do Extrato de Camellia sinensis na Corrosão do Aço-Carbono $1020 \mathrm{em} \mathrm{HCl} 1$ mol L-1. Virtual Química, 7(5): 1780-1794. http://rvqsub.sbq.org.br/index.php/rvq/article/view/1220/645

[14] Tussolini, M.; Spagnol, C.; Gomes, E.C.; Cunha, M.T..; Rodrigues, P.R.P. (2007). Estudo do comportamento eletroquímico do benzotriazol e benzimidazol na oxidação do aço inoxidável tipo ABNT 304. Revista Escola de Minas, 60(1): 41-44. https://dx.doi.org/10.1590/S0370-

44672007000100006 


\section{Bapítulo 10}

\section{PERFIL DE USO DE AGROTOXICOS NO POVOADO CANGANDU, ARAPIRACA -ALAGOAS}

\section{Helane Carine de Araújo Oliveira}

Aldenir Feitosa dos Santos

João Gomes da Costa

Jessé Marques da Silva Júnior Pavão

Maxwel Costa de Amorim

Resumo: O tema Agrotóxicos é de grande importância pois o território brasileiro se destaca em uso desses agroquímicos que são usados no combate à pragas, doenças e ervas daninhas para manter a produtividade agrícola. O presente trabalho visa caracterizar 0 processo de produção agrícola e o perfil sociodemográfico de 31 pequenos agricultores do povoado de Cangandú, município de Arapiraca em Alagoas através de entrevista semiestruturada. Constatou-se que 54,83\% possui ensino fundamental incompleto e $25,80 \%$ não sabe ler. Quanto ao uso de Equipamento de Proteção Individual-EPI, 45,16\% dos agricultores não faz uso no momento da preparação do produto e 41,93\% não faz uso no momento da aplicação; $25,80 \%$ queima as embalagens de agrotóxico após uso, $12,90 \%$ joga no campo e $6,45 \%$ faz a devolução das embalagens. Apenas 29,03\% afirmou ter recebido orientação sobre a utilização de agrotóxicos, tal fato, somado à baixa escolaridade podem ter contribuído para as ações inadequadas de manejo agrícola, como a não devolução das embalagens e uso inadequado de EPI. Por isso é importante o acompanhamento e fiscalização de órgãos ambientais, da agricultura e da saúde em todas as esferas, principalmente de forma a prevenir contaminações, garantido a segurança à saúde humana, dos demais seres vivos e do meio ambiente.

Palavras-chave: Práticas Agrícolas; Meio Ambiente; Homem. 


\section{INTRODUÇÃO}

No Brasil, o uso dos agrotóxicos começou a se difundir em meados da década de 40 . No final da década de 60, o consumo se acelerou em função da isenção de impostos e das taxas de importação de produtos não produzidos no Brasil (SOARES, 2010).

No Brasil, em 1965 teve a criação do Sistema Nacional de Crédito Rural, que vinculava a obtenção de crédito agrícola à obrigatoriedade da compra de insumos químicos pelos agricultores, e em 1975 a criação do Programa Nacional de Defensivos Agrícolas, o que acarretou na disseminação do uso de agrotóxicos. Entre 2001 e 2008 o uso de agrotóxicos no Brasil assumiu proporções assustadoras, a venda de venenos agrícolas no país saltou de pouco mais de U\$\$ 2 bilhões para mais de U\$\$ 7 bilhões, quando alcançamos a triste posição de maior consumidor mundial de venenos. Foram 986,5 mil toneladas de agrotóxicos aplicados (LONDRES, 2011).

As consequências decorrentes da utilização dos agrotóxicos no meio rural são em geral condicionadas por fatores intrinsecamente relacionados, como por exemplo, o uso inadequado dessas substâncias, a pressão exercida pela indústria e comércio para sua utilização, a alta toxicidade de certos produtos, a ausência de informações sobre a saúde e a deficiência dos mecanismos de vigilância, que têm sido muito precárias (PERES et al., 2007).

O crescente uso de agrotóxicos na produção agrícola e a consequente presença de resíduos muitas vezes acima dos níveis autorizados nos alimentos têm sido alvos de preocupação no âmbito da saúde pública, exigindo, das diversas esferas de governo, a implementação de ações de controle do uso de agrotóxicos (BRASIL, 2016).

O Estado de Alagoas não é diferente dos demais quanto ao uso de agrotóxicos, portanto é imprescindível a realização de pesquisas sobre os impactos socioambientais causados pelo manejo inadequado desses produtos. Objetiva-se com esse trabalho caracterizar o processo de produção agrícola e o perfil sociodemográfico de pequenos produtores do povoado Cangandú no Município de Arapiraca - Alagoas.

\section{METODOLOGIA}

Para o recrutamento dos sujeitos e aquisição do Termo de Consentimento Livre e Esclarecido (TCLE), os agricultores em exercício de suas atividades, credenciados na associação de agricultores do Povoado Cangandú no município de Arapiraca Alagoas, foram convidados a participar da pesquisa após a apresentação do projeto. Os interessados em participar da pesquisa, tomaram ciência do conteúdo presente no TCLE e assinaram duas vias do referido termo.

Dos agricultores abordados, 31 pequenos proprietários rurais de Cangandú participaram de uma entrevista semiestruturada, cujo questionário foi adaptado da metodologia de Magalhães (2010). Através do questionário foi possível caracterizar o processo de produção agrícola e o perfil sociodemográfico de pequenos produtores do povoado.

\section{RESULTADOS E DISCUSSÃO}

De acordo com o resultado da entrevista, $74,20 \%$ dos agricultores são do sexo masculino e $25,80 \%$ do sexo feminino; $16,12 \%$ tem idade igual ou menor a 20 anos, 35,48\% tem idade entre 20 e 40 anos, $45,16 \%$ com idade entre 40 e 60 anos e 3,24\% tem idade acima de 60 anos.

Quanto à escolaridade, $54,86 \%$ possui o ensino fundamental incompleto, $25,80 \%$ não sabe ler, $9,67 \%$ possuem ensino médio incompleto, $9,67 \%$ possui ensino médio completo. De acordo com Silva, R.; Silva, J.; Silva, W (2013), o baixo nível de escolaridade dos entrevistados demonstra a vulnerabilidade destes indivíduos quanto à percepção de risco e a compreensão das informações contidas nos rótulos das embalagens dos agrotóxicos.

Em relação à renda, 48,38\% ganha até um salário mínimo, 25,82\% ganha a partir de 1 até 2 salários e 25,8\% não respondeu; 45,16\% destina seus produtos agrícolas para venda e consumo, 19,35\% apenas consome, 12,90\% apenas vende e 22,59 não respondeu.

Dos 18 produtos agrícolas mencionados, os que mais se destacaram foram: feijão (Phaseolus vulgaris) com 22,22\%, milho (Zea mays) com 18,05\% e mandioca (Manihot esculenta Crantz) com $12,5 \%$, os demais totalizam $47,23 \%$. Dos entrevistados, $67,74 \%$ usa agrotóxicos nas culturas, 6,45\% 
respondeu não fazer uso e 25,81\% não respondeu.

No que diz respeito a orientação de como utilizar agrotóxicos, 41,94\% respondeu ter recebido orientação, 29,03\% não recebeu e $29,03 \%$ não respondeu. Ainda no quesito orientação, relacionado à proteção dos agrotóxicos pelo uso de Equipamento de Proteção Individual (EPI), 38,70\% respondeu ter recebido orientação, 32,25 não recebeu e 29,05\% não respondeu. Em concordância com esses resultados, Simonetti et al., (2016) constatou que a maioria dos agricultores tem noção de conhecimento e grau de periculosidade sobre agrotóxicos mais mesmo assim não seguem todas as exigências recomendadas.

Sobre o uso dos EPl's para o momento da preparação do produto, 45,16\% não faz uso, $22,58 \%$ usa e $32,26 \%$ não respondeu. No momento da aplicação do agrotóxico, 41,94\% não faz uso de EPI, 22,58\% utiliza e 35,48\% não respondeu.

Os agricultores que afirmaram usar EPI, indicaram o maior uso para botas, luvas e máscara, ou seja, não usavam os EPIs completos, aumentando assim os riscos de contaminação (Tabela 01).

Tabela 01. Uso de Equipamento de Proteção Individual (EPI) pelos agricultores de Cangandú, Arapiraca - Alagoas

\begin{tabular}{|l|c|c|}
\multicolumn{1}{|c}{ EPI } & $\begin{array}{c}\text { FREQUÊNCIA } \\
\text { RELATIVA } \\
(\%)\end{array}$ \\
\hline LUVAS & 9 & 15,78 \\
\hline MÁSCARAS & 8 & 14,03 \\
\hline BOTAS & 7 & 12,28 \\
\hline CHAPÉU & 5 & 8,77 \\
\hline CAPA & 5 & 8,77 \\
\hline NÃO RESPONDEU & 23 & 40,37 \\
\hline \multicolumn{2}{|c|}{ Fonte: Dados da Pesquisa (2018) }
\end{tabular}

Com relação a utilização de EPI, Silva, R.; Silva, J.; Silva, W (2013) relatam resultado semelhante, mencionando que os horticultores interrogados consideraram como EPI apenas botas e luvas.

Em estudo, Martins et al., (2012), relata que a razão alegada pelos agricultores para a não utilização dos EPI's se deu pela carência financeira, ausência de informação sobre a importância da segurança diante o manuseio com esses agentes químicos, e em outras circunstâncias tratou-se de um comportamento voluntário de desleixo dos agricultores ao cumprimento das normas de segurança previstas nos rótulos e normativos.

Com relação à frequência de aplicação de agrotóxicos, os agricultores relataram aplicar semanalmente $(43,38 \%)$, ficando a aplicação mensal em segundo lugar (11,32\%). A exposição semanal aos agrotóxicos também foi observada no estudo realizado por Leão et al., (2018).
Sobre a tríplice lavagem, técnica que deve ser feita na embalagem após término do agrotóxico, apenas $5,66 \%$ faz uso dessa técnica, 9,44\% não faz, 1,88\% respondeu não saber e $83,02 \%$ não respondeu. Sabe-se da importância da tríplice lavagem por questões de segurança sendo uma técnica indispensável, de acordo com a Lei dos Agrotóxicos, Lei oㅡ 7.802 (1989) e com a Associação Brasileira de Normas Técnicas (ABNT), NBR13968 (BRASIL, 1997).

No que se refere ao descarte das embalagens de agrotóxicos, a maioria queima (Tabela 02), apesar da Lei dos Agrotóxicos, Lei 끄 7.802, estar em vigor no Brasil desde 1989, que relata a responsabilidade por parte do usuário de fazer a devolução das embalagens. Essas e outras recomendações encontram-se presentes na bula ou folheto complementar na embalagem dos agrotóxicos. É de extrema importância que todas as informações sejam respeitadas e atendidas. 
Tabela 02. Destino das embalagens de agrotóxicos pelos agricultores de Cangandú, Arapiraca Alagoas

\begin{tabular}{|l|c|c|}
\multicolumn{1}{|c|}{ Destino das embalagens } & $n$ & Frequência relativa (\%) \\
\hline Queima & 8 & 25,80 \\
\hline Joga no campo & 4 & 12,90 \\
\hline Enterra & 3 & 9,67 \\
\hline Devolve para o vendedor & 2 & 6,45 \\
\hline Guarda & 2 & 6,45 \\
\hline Joga em lixo comum & 1 & 3,22 \\
\hline Não respondeu & 11 & 35,51 \\
\hline
\end{tabular}

Fonte: Dados da Pesquisa (2018)

\section{CONCLUSÕES}

Considerando os resultados obtidos, percebese que a negligência dos agricultores em relação às boas práticas e manejo correto dos agrotóxicos pode estar relacionada a baixa escolaridade dos agricultores e a falta orientação que parte dos entrevistados não recebeu. Dessa forma, é urgente a oferta de uma efetiva orientação técnica, de educação ambiental e até da educação formal para os

\section{REFERÊNCIAS}

[1] Brasil.. Programa de análise de resíduos de agrotóxicos em alimentos (PARA) relatório das análises de amostras monitoradas no período de 2013 a 2015. ANVISA. Brasília, novembro de 2016.

[2] Associação Brasileira de Normas Técnicas. NBR13968 - Embalagem rígida vazia de agrotóxico - Procedimentos de lavagens. Rio de Janeiro, 1997.

[3] Lei $n^{\circ} 7.802$, de 11 de Julho de 1989. Dispõe sobre a pesquisa, a experimentação, a produção, a embalagem e rotulagem, o transporte, o armazenamento, o destino final dos resíduos e embalagens, o registro, a classificação, o controle, a inspeção e a fiscalização de agrotóxicos, seus componentes e afins, e dá outras providências. Diário Oficial da República Federativa do Brasil, Brasília, 1989.

[4] Leão, Renata Spolti et al. Avaliação de saúde pública por exposição a agroquímicos: uma experiência com a agricultura familiar no noroeste do Rio de Janeiro. Sustentabilidade em Debate, v. 9, n. 1, p. 81-94, 2018.

[5] Londres, Flavia. Agrotóxicos no Brasil: um guia para ação em defesa da vida. - Rio de Janeiro: AS-PTA - Assessoria e Serviços a Projetos em Agricultura Alternativa, 2011. 190 p. Disponível em: $\quad$ <http://aspta.org.br/2011/09/lancamento-dolivro-agrotoxicos-no-brasil-um-guia-para-acao-emdefesa-da-vida/agotoxicos-no-brasil-mobile/>. Acesso em 08 de março de 2018.

[6] Magalhães, Maria Auxiliadora de Sá. Exposição a agrotóxicos na atividade agrícola: um estudo de percepção de riscos à saúde dos trabalhadores rurais no distrito de pau de ferroSalgueiro-Pe. 2010. 144 f. Dissertação (Saúde agricultores rurais, principalmente para os pequenos e médios, que não possuem poder aquisitivo de contratar assistência técnica.

Também é de fundamental importância o acompanhamento e fiscalização de órgãos ambientais, agricultura e saúde, trabalhando principalmente de forma a prevenir contaminações, garantido assim a segurança à saúde humana, demais seres vivos e do meio ambiente.

pública) - Centro de Pesquisas Aggeu Magalhães, Recife, 2010.

[7] Martins Myrella Klesy Silva et al. Exposição ocupacional aos agrotóxicos: um estudo transversal. Revinter Revista Intertox de Toxicologia, Risco Ambiental e Sociedade, São Paulo, v. 5, n. 3, p. 6-27, outubro de 2012.

[8] Peres, Frederico; Moreira, Josino Costa. Saúde e ambiente em sua relação com o consumo de agrotóxicos em um pólo agrícola do Estado do Rio de Janeiro, Brasil. Cadernos de Saúde Pública, v. 23, p. S612-S621, 2007.

[9] Silva, R. N.; Silva, J. M.; Silva, W. C. Horticultores e agrotóxicos: estudo de caso no município de Arapiraca (AL). Revista IberoAmericana de Ciências Ambientais, Aquidabã, v.4, n. 1, p.56-68, 2013.

[10] imonetti, Ana Paula Morais Mourão et al. Conhecimento sobre Agrotóxicos no Meio Rural do Município de Nova Aurora-Paraná. Revista Thêma et Scientia, v. 6, n. 1, p. 261-271, 2016.

[11]

oares, W.L. Uso dos agrotóxicos e seus impactos à saúde e ao ambiente: uma avaliação integrada entre a economia, a saúde pública, a ecologia e a agricultura. 2010. 163f.Tese (Doutorado em Ciências na área de Saúde Pública e Meio Ambiente) - Escola Nacional de Saúde Pública Sergio Arouca - ENSP. Rio de Janeiro, 2010. 


\section{Capítulo 11}

\section{INTERACÕES ENTRE A CANTAXANTINA E COMPONENTES CELULARES: POSSIVVEIS MECANISMOS TOXICOLÓGICOS}

\section{Marina Matos Souto}

\section{Marta Maciel Dudus}

Raiane Fonseca Silva Herdy

Xiaoxin $W u$

\section{Juliana Tomaz Latini}

\section{Kátia Calvi Lenzi de Almeida}

Resumo: A cantaxantina é uma xantofila polar largamente utilizada na indústria alimentícia e cosmética por suas propriedades de pigmentação. Sua ingestão está relacionada a retinopatia em humanos e danos hepáticos em animais. Pouco se sabe sobre os mecanismos de toxicidade da cantaxantina. Objetivo: Objetiva-se com esse estudo elaborar hipóteses sobre os mecanismos toxicológicos da cantaxantina. Metodologia: Foi realizada busca na base de dados Pubmed, utilizando os termos "canthaxanthin toxicity", "canthaxanthin lesions" e "canthaxanthin damage", dos 69 resultados gerados, 12 foram selecionados. Além disso, dados do presente grupo de estudo foram incluídos. Principais Resultados: O potencial tóxico da cantaxina está relacionado ao seu transporte mediado por RBPs. A partir da análise de motifs da RBPII foram identificados sítios de ligação para diversas proteínas celulares, tais interações podem permitir o acesso do carotenoide a componentes celulares e modificações dos mesmos. A indução e inibição de algumas enzimas hepáticas pode resultar em danos, principalmente ao tecido hepático. A integração da cantaxantina às membranas biológicas resulta em modificações na espessura, fluidez e permeabilidade das mesmas. Principais conclusões: os mecanismos toxicológicos da cantaxantina resultam de suas propriedades químicas, as quais permitem sua interação e modificação de componentes celulares.

Palavras-chave: Cantaxantina; Toxicidade; RBPII, Membranas biológicas. 


\section{INTRODUÇÃO}

A cantaxantina é um carotenoide lipossolúvel do grupo xantofila, com potente atividade antioxidante e imunomoduladora, cuja molécula é composta por uma cadeia polieno, contendo anéis $\beta$-ionona ligados a grupos cetona e carbonila nas extremidades. Ocorre naturalmente como pigmento em bactérias, fungos $e$ algas. Pode ser sintetizada industrialmente como corante, possuindo grande relevância econômica e sendo amplamente utilizado como aditivo nas indústrias alimentícia e cosmética; com destaque para sua utilização na ração de salmão e truta criados em cativeiro por sua capacidade de conferir a coloração alaranjada característica do pescado selvagem - o qual obtém sua coloração por dieta rica em crustáceos. Tal efeito é resultante de sua incorporação ao tecido muscular, possibilitada por meio da ligação ao complexo actinomiosina (Dudus, 2017; Mathews, 2005; Esatbeyouglu e Rimbach, 2016).

Seu consumo em altas doses está relacionado a alguns riscos para a saúde, existindo relatos de retinopatia e anemia aplásica em humanos consumidores do pigmento em pílulas de autobronzeamento e lesões hepáticas em murinos. A retinopatia é caracterizada por deposição de cristais amarelados na camada interna da retina, especificamente ao redor da papila e mácula lútea (Dudus, 2017; Daicker et al, 1987; Challiol et al, 2018; Sujak, 2009, 2012; Dettoraki e Moschos, 2016). No Brasil a utilização da cantaxantina como aditivo alimentício é regulamentada desde 1998, porém no regulamento não existe referência a dose limite (Dudus, 2017).

O potencial tóxico da cantaxantina é reconhecido mas pouco entende-se sobre seus mecanismos moleculares de toxicidade. A produção científica sobre o tema é escassa, a despeito da franca expansão do consumo de alimentos contendo este carotenoide.

Objetiva-se com esse trabalho elaborar hipóteses sobre os mecanismos toxicológicos da cantaxantina a partir de dados da literatura científica.

\section{METODOLOGIA}

O presente estudo foi construído a partir de revisão da literatura abordando os possíveis mecanismos toxicológicos da cantaxina. Foi realizada em maio de 2018 uma busca eletrônica na base de dados Pubmed, escolhida pela amplitude e qualidade do conteúdo. Os termos de busca utilizados em inglês foram: "canthaxanthin toxicity", "canthaxanthin lesions" e "canthaxanthin damage". Devido à escassez de produções científicas sobre o tema não ocorreu exclusão de artigos baseada em critérios como data e tipo de estudo, sendo o critério de inclusão a adequação ao tema do estudo. Além dos dados selecionados na revisão de literatura, também foram utilizados os resultados publicados em produção prévia do presente grupo de pesquisa. A partir da seleção e análise de dados, foram elaboradas hipóteses para os mecanismos moleculares da toxicidade da cantaxantina.

\section{RESULTADOS E DISCUSSÃO}

A busca resultou em 69 resultados, dos quais foram selecionados 12, que melhor se adequaram a temática do presente estudo. Os trabalhos compreendiam informações sobre os processos de digestão e absorção, transporte plasmático, deposição em tecidos, integração a membranas lipídicas e inibição de enzimas hepáticas pela cantaxantina. A partir de tais dados, torna-se possível traçar hipóteses relacionadas à possível toxicidade do pigmento.

Os animais são incapazes de sintetizar carotenoides. Estes provêm da dieta, sendo que a cantaxantina pode ser obtida na carne de pescados: salmão ou truta salmonada. Sua digestão a partir da emulsificação e hidrólise por lipases resulta em desincorporação do quimo e inclusão em micelas mistas, as quais possibilitam $O$ acesso a superfície dos enterócitos. A absorção ocorre por difusão passiva ou a partir de receptores no revestimento epitelial do intestino delgado. A cantaxantina é disponibilizada a circulação por quilomícrons, obtendo assim acesso aos tecidos periféricos (Chitchumroonchokchai e Failla, 2016; Esatbeyouglu e Rimbach, 2016; Sujak, 2009). Estudos a respeito da absorção da cantaxantina evidenciaram otimização deste processo quando o composto é ingerido em associação com lipídeos; logo pode-se postular que a carne do pescado criada em cativeiro, rica em gorduras saturadas, promove maiores concentrações corpóreas do corante (Petri e Lundebye, 2006; Esatbeyouglu e Rimbach, 2016).

O transporte plasmático da cantaxantina pode ser mediado por lipoproteínas, tais como LDL 
e HDL (Esatbeyouglu e Rimbach, 2016; Matthews et al. 2006). Devido ao caráter insolúvel e quimicamente instável do carotenoide, outros autores indicam a necessidade de proteínas específicas para tal transporte; que atuariam solubilizando $e$ protegendo a molécula. Atuam nessa função a Proteína de Ligação ao Retinol (RBP) plasmática e a Proteína de Ligação Celular de Retinol (RBP II) citoplasmática (Menozzi, Polverini e Berni, 2018; Dudus, 2017). Os prováveis sítios de depósito são a retina, fígado, rins, pulmões, pele e tecido adiposo; sendo o acúmulo nos tecidos retinal, hepático e renal associado a lesões em estudos com modelos animais (Petri e Lundebye, 2006; Dudus, 2017; Esatbeyouglu e Rimbach, 2016).

Dudus (2017) postula sobre o papel das RBP na toxicidade da cantaxantina. Essas proteínas receptoras têm capacidade de ligação a componentes celulares, logo sua atividade de transporte da cantaxantina e mediação das interações intermoleculares da mesma pode resultar em alterações celulares. A análise de motifs - pequenos domínios proteicos que medeiam as interações proteína-proteína - da RBP II humana, de murinos e do salmão pela ferramenta Eukaryotic Linear Motif (ELM) detectou vários que interagem com proteínas de clivagem, proteínas ligadoras, adaptadoras, de fosforilação, dentre outras; podendo implicar na participação da cantaxantina em alterações subletais e letais (Dudus, 2017).

A metabolização do carotenoide ocorre principalmente no fígado; sendo que Jewell e O'Brien (1999) demonstraram potente indução de enzimas do citocromo P450 1A1, 1A2, 2B1/2, 1A1/2, 2B1/2 e $3 A$ nos tecidos hepático, renal e pulmonar. Zheng et al. (2013, 2016) demonstraram inibição reversível das enzimas hepáticas de fase I CYP2C19 e de fase II UGT1A1 e UGT1A3 - em ambos os casos a inibição é moderada e dosedependente. Sendo o fígado um sítio preferencial de acúmulo, a possibilidade de danos aos hepatócitos não pode ser excluída (Jewell e O'Brien, 1999; Zheng et al., 2013, 2016).

Em estudos a partir da espectroscopia de fluorescência e métodos de simulação molecular, Jia et al. (2017) comprovaram o potencial da cantaxantina de interagir com a albumina sérica humana (HSA) - via ligações de hidrogênio e de Van der Waals - e modificar a estrutura secundária da mesma. Considerando $\mathrm{O}$ importante papel de transporte da HSA, modificações induzidas pela cantaxantina podem resultar em prejuízos funcionais, sendo a mesma lógica utilizada para outros aditivos sintéticos (Jia et al., 2017).

Os dados mais expressivos em relação a toxicidade da cantaxantina indicam que esta resulta da integração e modificação de membranas biológicas. A cantaxantina geralmente se integra à membrana em orientação vertical, de modo que suas regiões polares e apolares coincidam com as dos fosfolipídeos. A ligação entre a cadeia polieno e as cadeias alquil dos fosfolipídeos se dá por interações de Van der Waals e favorecem a conformação estendida dos fosfolípideos, aumentando a espessura do core hidrofóbico da membrana (Sujak, 2007, 2009, 2012; Gruszecki e Strzalka, 2005).

As porções polares se unem por ligações de hidrogênio entre os grupos cetona da cantaxantina e o grupo carbonila da cabeça polar dos fosfolipídeos, resultando em imobilização dos grupos fosfato que pode resultar em agregação de vesículas. São notadas alterações das propriedades térmicas da membrana resultando em maior fluidez e a permeabilidade da membrana a solutos polares é reduzida (Sujak, 2007, 2009, 2012; Gruszecki e Strzalka, 2005).

Nos casos de retinopatia, o dano aos capilares retinais pode ser resultante de alterações da membrana endotelial pela deposição da cantaxantina. Considerando que fígado e rins também são órgãos altamente vascularizados, a deposição de cantaxantina em seu endotélio e potencial desestabilização da membrana podem resultar em edema, hemorragia e necrose; alterações notadas na análise histológica de órgãos de murinos com dieta rica em cantaxantina (Dudus, 2017).

\section{CONCLUSÕES}

Os mecanismos moleculares de toxicidade da cantaxantina provêm de suas propriedades de interação e modificação de proteínas celulares; processo que pode ser mediado por moléculas de transporte, como é o caso das RBPs. A alta lipossolubilidade e o caráter anfipático da molécula resultam na capacidade de integração e modificação das propriedades das membranas biológicas. Além disso prováveis danos metabólicos por 
inibição dos sistemas enzimáticos hepáticos

\section{REFERÊNCIAS}

[1] Challiol, C. F. et al. Retinal toxicity due to canthaxanthin. Case series. Archivos de la Sociedad Española de Oftalmología (English Edition), 2018.

[2] Chitchumroonchokchai, Chureeporn; Failla, Mark L. Bioaccessibility and intestinal cell uptake of astaxanthin from salmon and commercial supplements. Food Research International, v. 99, p. 936-943, 2017.

[3] Daicker, B. et al. Canthaxanthin retinopathy. Graefe's archive for clinical and experimental ophthalmology, v. 225, n. 3, p. 189197, 1987.

[4] Dettoraki, Maria; Moschos, Marilita M. The role of multifocal electroretinography in the assessment of drug-induced retinopathy: a review of the literature. Ophthalmic research, v. 56, n. 4, p. 169-177, 2016.

[5] Dudus, M. M. Efeitos Toxicológicos da Cantaxantina Sobre a Prole da Camundongas Consumidoras de Truta Salmonada. 2017. 60 f. Dissertação (Mestrado em Ciências Ambientais e Conservação) - Universidade Federal do Rio de Janeiro Campus Macaé/NUPEM. 2017.

[6] Esatbeyoglu, Tuba; Rimbach, Gerald. Canthaxanthin: From molecule to function. Molecular nutrition \& food research, v. 61, n. 6, p. 1600469, 2017.

[7] Gruszecki, Wiesław I.; Strzałka, Kazimierz. Carotenoids as modulators of lipid membrane physical properties. Biochimica et Biophysica Acta (BBA)-Molecular Basis of Disease, v. 1740, n. 2, p. 108-115, 2005.

[8] Jewell, Christopher; O'brien, Nora M. Effect of dietary supplementation with carotenoids on xenobiotic metabolizing enzymes in the liver, lung, kidney and small intestine of the rat. British Journal of Nutrition, v. 81, n. 3, p. 235-242, 1999. também devem ser considerados.

[9] JIA, Jie et al. Exploration of interaction of canthaxanthin with human serum albumin by spectroscopic and molecular simulation methods. Luminescence, v. 33, n. 2, p. 425-432, 2018.

[10] Matthews, Sarah J. et al. Astaxanthin binding protein in Atlantic salmon. Comparative Biochemistry and Physiology Part B: Biochemistry and Molecular Biology, v. 144, n. 2, p. 206-214, 2006.

[11] Menozzi, Ilaria; Polverini, Eugenia; Berni, Rodolfo. Deciphering protein dynamics changes along the pathway of retinol uptake by cellular retinol-binding proteins 1 and 2 . Archives of biochemistry and biophysics, v. 645, p. 107-116, 2018.

[12] Petri, Dietrich; Lundebye, Anne-Katrine. Tissue distribution of astaxanthin in rats following exposure to graded levels in the feed. Comparative Biochemistry and Physiology Part C: Toxicology \& Pharmacology, v. 145, n. 2, p. 202-209, 2007.

[13] Sujak, Agnieszka et al. Organization of two-component monomolecular layers formed with dipalmitoylphosphatidylcholine and the carotenoid pigment, canthaxanthin. Molecular membrane biology, v. 24, n. 5-6, p. 431-441, 2007.

[14] Sujak, Agnieszka. Exceptional molecular organization of canthaxanthin in lipid membranes. Acta Biochimica Polonica, v. 59, n. 1, 2012.

[15] Sujak, Agnieszka. Interactions between canthaxanthin and lipid membranes-possible mechanisms of canthaxanthin toxicity. Cellular \& molecular biology letters, v. 14, n. 3, p. 395, 2009.

[16] Zheng, Yu Fen et al. Inhibitory effects of astaxanthin, $\beta$-cryptoxanthin, canthaxanthin, lutein, and zeaxanthin on cytochrome P450 enzyme activities. Food and chemical toxicology, v. 59, p. 78-85, 2013. 


\section{Gapítulo 12}

\section{SISTEMA DE PRODUÇÃO DE BIOGÁS PARA APROVEITAMENTO DE RESIDUOS ORGÂNICOS EM NAVIOS MERCANTES}

\section{Stéfany Larissa Dantas Nascimento}

\section{Diego Leon da Silva Monteiro \\ Kevin Harley Ferreira Moura \\ Pedro Rodrigues Bozi Ferrete}

Resumo: Em navios mercantes, especialmente os de passageiros, há uma grande quantidade de resíduos orgânicos descartados, provenientes de esgoto e de alimentos. A matéria orgânica disponível pode ser melhor aproveitada, evitando-se seu descarte no mar. O Biogás é uma fonte de energia alternativa que pode ser obtida a partir da biodegradação anaeróbica dessa matéria orgânica. Este gás é constituído principalmente de metano, gás atóxico e inflamável. O presente artigo traz o desafio para que essa energia se torne viável e aproveitada em navios de passageiros ou, ainda, em outros tipos de navios mercantes. A geração de biogás pode ser projetada em um espaço reduzido dentro dos navios, reduzindo os custos com gás liquefeito de petróleo e podendo ser utilizada em outros compartimentos que utilizam eletricidade como fonte de energia. A metodologia empregada baseou-se na pesquisa de dados de resíduos orgânicos gerados em navios mercantes, correlacionando-os com dados sobre a quantidade de biogás gerada por matéria orgânica, tendo como embasamento experimentos semelhantes realizados em terra. A associação dos dados disponíveis com as especificações explicitadas nos experimentos revela a viabilidade econômica e estrutural da planta de produção de biogás a bordo e seu potencial de aproveitamento.

Palavras Chave: biogerador; esgoto; meio ambiente; geração de metano. 


\section{INTRODUÇÃO}

Navios mercantes, em especial os navios cruzeiros, de passageiros e de carga viva, produzem uma grande quantidade de resíduos orgânicos, sendo restos de alimentos e esgoto os mais relevantes. O gerenciamento desses resíduos a bordo, em geral, consiste no tratamento de uma pequena parcela do material para descarte no mar e na recepção do restante pelos portos, conforme estabelecido nos Anexos IV e V da Convenção Internacional para a Prevenção da Poluição por Navios (MARPOL, 73/78). Tamanha disponibilidade de matéria orgânica pode, no entanto, ser aproveitada de forma a gerar economia para o navio, sendo utilizada na produção de biogás que, por sua vez, é uma fonte de energia.

A geração de biogás vem ao longo dos anos crescendo como fonte de energia alternativa e diversos segmentos produtivos têm adotado essa opção. Entretanto, vários fatores necessitam ser avaliados para a máxima obtenção de biogás a partir da matéria orgânica disponível, com rendimentos aproveitáveis e menor custo possível. A qualidade e a quantidade de biogás produzido requerem o controle de vários parâmetros físico-químicos, e o tipo de matéria orgânica utilizada na sua obtenção é de fundamental importância. Durante o processo de produção, ocorre a obtenção de outros gases que não contribuem com o processo e são considerados impurezas. Esses gases necessitam ser removidos para que o gás principal, o metano, tenha aproveitamento energético satisfatório, ou seja, seu poder calorífico mantenha-se no valor basal, em torno de 8 a $9 \mathrm{mil} \mathrm{kcal} / \mathrm{m}^{3}$ de gás. A proporção de gás metano em relação ao gás carbônico produzido no reator também depende das características do composto orgânico a ser degradado.

Nos sistemas anaeróbicos, verifica-se que a maior parte do material orgânico biodegradável presente no despejo é convertida em biogás (cerca de 70 a 90\%), que é removido da fase líquida e deixa o reator na forma gasosa. Apenas uma pequena parcela do material orgânico é convertida em biomassa microbiana (cerca de 5 a 15\%), vindo a constituir o lodo excedente do sistema. O material não convertido em biogás ou em biomassa deixa o reator como material não degradado (10 a 30\%), podendo ser armazenado a bordo para posterior direcionamento ao porto.
A geração do gás é feita por fases, a saber: a hidrólise (quebra do material orgânico em moléculas), a fermentação (processo de formação de ácidos e alcoóis e por seguinte a formação do ácido acético) e, por fim, a metanogênese (fase em que os ácidos acéticos se tornam metano e dióxido de carbono, há também a formação desses direto da fase de alcoóis, que representa 30\% da produção total).

O metano produzido no processo de digestão anaeróbica é rapidamente separado da fase líquida, devido à sua baixa solubilidade em água, resultando num elevado grau de degradação dos despejos líquidos, uma vez que o gás deixa o reator com a fase gasosa. O dióxido de carbono, por sua vez, é bem mais solúvel em água que o metano, saindo do reator parcialmente como gás e parcialmente dissolvido no efluente líquido.

A quantidade de resíduos orgânicos sólidos biodegradáveis nas atividades a bordo dos navios e a quantidade de esgoto produzido e as suas respectivas misturas são parâmetros fundamentais no dimensionamento de um reator compacto para navios mercantes. As dimensões do sistema variam de 5 a $20 \mathrm{~m}^{3}$, de acordo a necessidade de produção e espaço físico disponível. O controle do $\mathrm{pH}$, a temperatura e a carga de resíduos orgânicos no interior do reator anaeróbico são fatores importantes na geração do biogás. O projeto deve conter, também, medidas e equipamentos de segurança contra explosões e incêndios, devido à alta inflamabilidade do gás metano, bem como contra altas concentrações ou vazamentos de enxofre.

Diante do exposto, o presente trabalho se propõe a analisar tais parâmetros e fatores, a fim de viabilizar a utilização do biogás como fonte de energia elétrica a bordo de navios mercantes.

\section{METODOLOGIA}

A metodologia empregada na pesquisa se baseou em levantamento bibliográfico em livros, relatórios técnicos de resíduos a bordo, analisando-se estudos e documentos e utilizando dados do Scielo (Scientific Eletronic Library Online), tomando por base método já empregado na Universidade de São Paulo (COELHO, VELASQUEZ; SILVA, 2006) e adaptando-se o dimensionamento do sistema para um navio mercante. 


\section{RESULTADOS E DISCUSSÃO}

A quantidade de energia obtida a partir do Biogás a bordo de navios mercantes dependerá da quantidade de resíduos orgânicos biodegradáveis e também do esgoto gerado e produzido. Tais fatores, por sua vez, dependem do tipo da quantidade de passageiros e tripulantes, da duração da viagem e, consequentemente, do tipo de navio. A tabela 1 apresenta as quantidades de esgoto geradas em diferentes tipos de navios, com diferentes tecnologias.

Tabela 1: Quantidade de esgoto produzida por tipo de navio

\begin{tabular}{|c|c|c|c|c|}
\hline Tipo de navio & Tipo de tecnologia & Quantidade gerada & Período & Fonte \\
\cline { 2 - 5 } Cruzeiro & MSD II & $114 \mathrm{~m}^{3}$ por pessoa & Por semana & $\begin{array}{c}\text { Friends of the } \\
\text { Earth, 2009 }\end{array}$ \\
\cline { 2 - 5 } & AWTS & $0,004-0,1 \mathrm{~m}^{3}$ por pessoa & Por dia & EPA, 2008 \\
\hline Ferries & - & $0,1 \mathrm{~m}^{3}$ por pessoa & Por dia & HELCOM, 2014 \\
\hline \multirow{3}{*}{ Pesqueiro } & $\begin{array}{c}\text { The Tank } \\
\text { MSD } \AA\end{array}$ & $0,02 \mathrm{~m}^{3}$ de águas escuras por pessoa & Por dia & OCNMS, 2011 \\
\cline { 2 - 5 } & $\begin{array}{c}\text { Ahead } \\
\text { Tank® }\end{array}$ & $0,03 \mathrm{~m}^{3}$ de águas escuras por pessoa & Por dia & OCNMS, 2011 \\
\cline { 2 - 6 } & Orca ${ }^{\circledR}$ & $0,11 \mathrm{~m}^{3}$ de águas escuras por pessoa & Por dia & OCNMS, 2011 \\
\hline
\end{tabular}

A tecnologia do sistema sanitário do navio deve ser levada em consideração, uma vez que o sistema a vácuo produz menos água efluente. Uma grande quantidade de águas cinzas pode ser gerada, dependendo do sistema utilizado e, dependendo da sua constituição química, essas águas também podem ser empregadas no processo de produção de biogás. A tabela 2 mostra a quantidade de restos de alimentos produzidos em diferentes tipos de navios mercantes.

Tabela 2: Quantidade de restos de alimentos gerados a bordo

\begin{tabular}{|l|l|c|}
\hline \multicolumn{1}{|c|}{ Tipo de navio } & \multicolumn{1}{|c|}{ Restos de alimentos gerados } & Fontes \\
\hline Cruzeiro & $12 \mathrm{~m}^{3}$ por navio por semana & (EPA, 2008) \\
\hline Work vessel & $\begin{array}{l}175 \mathrm{~kg} / 0,35 \mathrm{~m}^{3} \text { por navio por semana }(0,3 \mathrm{~kg} \text { por pessoa por } \\
\text { semana }\end{array}$ & $\begin{array}{c}\text { (Tidy Planet, } \\
2015)\end{array}$ \\
\hline Cruzeiro & $3.5 \mathrm{~kg}$ por passageiro por dia & $(\mathrm{HPTI}, 2007)$ \\
\hline Cruzeiro & 18 to $32 \mathrm{~kg}$ por pessoa por semana & $(\mathrm{ASCl}, 2000)$ \\
\hline
\end{tabular}

Comparando-se navios mercantes de transporte de cargas e de passageiros de grande porte, as diferenças de resíduos sólidos e esgoto produzidos a bordo são enormes e, como consequência, a geração de biogás também. A matéria orgânica que deveria ser descartada (seja a parcela despejada no mar, seja a entregue ao porto) pode ser aproveitada para a geração de biogás em um reator anaeróbico. De acordo com SMITH (2013), 10 kg de matéria orgânica são suficientes para produzir $3 \mathrm{~m}^{3}$ de biogás, o que resulta em energia suficiente para $24 \mathrm{~h}$ de refrigeração ou 3h de iluminação.

A tabela 3 apresenta a quantidade de biogás produzida com base na quantidade de matéria orgânica disponível. O volume final de biogás depende fundamentalmente do tipo de matéria orgânica e da quantidade de sólidos dissolvidos no material. Dessa quantidade, aproveitam-se os sólidos voláteis para a produção de biogás. A porcentagem de $\mathrm{CH}_{4}$ disponível no total de biogás produzido determina a sua qualidade como combustível. 
Tabela 3: Quantidade de biogás produzida por matéria orgânica

\begin{tabular}{|c|c|c|c|c|}
\hline Matéria orgânica & $\begin{array}{l}\text { Sólidos totais (\% de } \\
\text { sólidos dissolvidos) }\end{array}$ & $\begin{array}{l}\text { Sólidos voláteis } \\
\text { (\% de sólidos } \\
\text { dissolvidos) }\end{array}$ & Produção de biogás & $\begin{array}{l}\text { Conteúdo de } \\
\mathrm{CH} 4(\%)\end{array}$ \\
\hline Esterco suíno & 3 a 81 & 70 a 80 & 0,25 a $0,50 \mathrm{~m}^{3} / \mathrm{kg}$ & 70 a 80 \\
\hline Esterco bovino & 5 a 12 & 75 a 85 & 0,20 a $0,30 \mathrm{~m}^{3} / \mathrm{kg}$ & 55 a 75 \\
\hline Restos de frutas & 15 a 20 & 75 & 0,25 a $0,50 \mathrm{~m}^{3} / \mathrm{kg}$ & Ind. \\
\hline Restos de alimentos & 10 & 80 & 0,50 a $0,60 \mathrm{~m}^{3} / \mathrm{kg}$ & 70 a 80 \\
\hline Esgoto & * & * & 0,01 a $0,05 \mathrm{~m}^{3} / \mathrm{m}^{3}$ & 50 a 70 \\
\hline
\end{tabular}

*: variáveis dependentes do sistema sanitário utilizado no navio.

Fonte: adaptado de STEFFEN (1998).

Navios de carga viva, especialmente navios boiadeiros, também produzem um grande aporte de matéria orgânica proveniente de fezes e urina dos animais, podendo também receber a bordo a tecnologia do biogerador. A quantidade de fezes gerada por uma cabeça de gado pode chegar a $20 \mathrm{~kg}$ por dia. Nesse caso, as variáveis a serem consideradas para o volume final da matéria orgânica são a quantidade de animais transportados, que pode chegar a 20.000 cabeças por navio, e a duração da viagem, que em média dura entre 15 e 40 dias.

De acordo com KHANAL (2008), a energia bruta disponível no biogás pode ser calculada utilizando-se a equação:

$$
E=G \times 22.400 \mathrm{~kJ} / \mathrm{m}^{3},
$$

sendo $\mathrm{E}$ a energia bruta em $\mathrm{kJ} /$ dia e $\mathrm{G}$ a produção de biogás no biodigestor em $\mathrm{m}^{3} /$ dia.
Essa quantidade, por sua vez, será utilizada para calcular o potencial de geração de energia elétrica, de acordo com a equação:

$$
P=E \times \eta \times 0,000278 \mathrm{kWh} / \mathrm{kJ} \text {, }
$$

em que $P$ é o potencial de geração de energia, E é a energia bruta em kJ/dia, e $\eta$ a eficiência do equipamento de geração de energia utilizado.
A tabela 4 compara os tipos de geradores que podem ser empregados no sistema, com base no dimensionamento e na eficiência

Tabela 4: Comparação entre os tipos de geradores

\begin{tabular}{|l|c|c|}
\hline \multicolumn{1}{|c|}{ Equipamento } & Porte apropriado da planta & Eficiência (\%) \\
\hline Motor de Combustão Interna Alternativo & Pequeno a médio & $30-35$ \\
\hline Turbina & Grande & $25-30$ \\
\hline Microturbina & Pequeno & $25-30$ \\
\hline Célula de Combustível & Pequeno & $35-40$ \\
\hline
\end{tabular}

Fonte: adaptado de PITTMAN (2002). 
O tipo de gerador que possui maior aplicabilidade nos navios mercantes é o Motor Alternativo, que pode ser acoplado à rede dos MCA's (Motores de Combustão Auxiliares), que compõem a planta de geração de energia elétrica a bordo.

\section{REFERÊNCIAS}

[1] CE Delft, Chew. European Maritime Safety Agency. The Management of Ship-Generated Waste On-board Ship. [S. I. : s. n.]. 2017, 89 p.

[2] Coelho, Suani Teixeira; Velazquez, Sílvia Maria Stortini González; SILVA, Orlando Cristiano da et al. Geração de energia elétrica a partir do biogás proveniente do tratamento de esgoto.. In: Encontro DE Energia no Meio Rural, 6., 2006, Campinas. Proceedings online... Available from: <http://www.proceedings.scielo.br/scielo.php?scrip $\mathrm{t}=$ sci_arttext\&pid=MSC0000000022006000100070 \&lng=en\&nrm=abn>. Acess on: 05 Aug. 2018.

[3] Smith, John E. Biotechnology. 5. ed. Cambridge University Press, 2009.

\section{CONCLUSÕES}

Diante dos dados apresentados, levando em consideração a quantidade de resíduos orgânicos gerados em navios e a consequente quantidade de biogás disponível, pode-se concluir a viabilidade da utilização do reator anaeróbico a bordo de navios mercantes para a geração de energia elétrica auxiliar, sendo seu uso mais vantajoso em navios de carga viva e de passageiros.

[4] Sommer, Sven G.; Christensen, Morten L.; Schmidt, Thomas; Jensen, Lars S. Animal Manure Recycling: Treatment and Management. Wiley, 2013.

[5] United States Environmental Protection Agency. Office of Wastewater Management. Graywater Discharges from Vessels. Washington, 2011. 27 p.

[6] Khanal, Samir K. Anaerobic Biotechnology for Bioenergy Production: Principles and Applications. Blackwell Publishing, 2008. 


\section{Capítulo 13}

\section{AUMENTO DA PRODUÇÃO DE METANO NO BIOGÁS A PARTIR DA CODIGESTÃO DE LODO DE ESGOTO COM DIFERENTES TIPOS DE RESÍDUOS}

\section{Janaína dos Santos Ferreira \\ Isaac Volschna Junior \\ Magali Christe Cammarota}

Resumo: A codigestão anaeróbia de lodo secundário de plantas de tratamento de esgoto com resíduo alimentar ou glicerol bruto foi avaliada em digestores de bancada sob condições mesofílicas $\left(30^{\circ} \mathrm{C}\right)$ e sem agitação. Na codigestão do lodo com diferentes proporções de resíduo alimentar (10 a 25\% v/v) verificou-se que a correção do pH inicial para 7,5 permitiu melhor tamponamento e maior remoção de sólidos voláteis (SV) e produção específica de metano (PEM). A adição de 10\% de resíduo alimentar ao lodo apresentou maior PEM (184 mL CH4/g SVaplicados) e redução de SV (67\%) em comparação ao controle (com lodo somente - $138 \mathrm{~mL}$ $\mathrm{CH} 4 / \mathrm{g}$ SVaplicados e 51\%). Baixas percentagens de glicerol bruto adicionado ao lodo $(<1 \% \mathrm{v} / \mathrm{v})$ reduziram a interferência da salinidade e permitiram aumento da produção de metano, sem prejudicar a estabilização da mistura. A adição de 0,5\% resultou em maior PEM (78 mL CH4/g SVaplicados) mas menor redução de sólidos voláteis (19\%, em média) que no controle ( $45 \mathrm{~mL} \mathrm{CH} 4 / \mathrm{g}$ SVaplicados e $32 \%$ ). Os resultados obtidos indicam que a codigestão anaeróbia de misturas binárias de lodo de esgoto e resíduo alimentar ou glicerol bruto é tecnicamente viável e pode contribuir para o aumento da produção de metano nos digestores de lodo de plantas de tratamento de esgoto, possibilitando seu aproveitamento energético.

Palavras Chave: Codigestão, Lodo de Esgoto, Glicerol, Resíduo Alimentar, Metano. 


\section{INTRODUÇÃO}

Resíduos sólidos são resíduos, no estado sólido e semissólido, que resultam de atividades de origem industrial, doméstica, hospitalar, comercial, agrícola, de serviços, e de varrição. Ficam incluídos nesta definição os resíduos dos serviços públicos de saneamento básico como os lodos provenientes de sistemas de tratamento de água e esgoto, aqueles gerados em equipamentos e instalações de controle de poluição, bem como determinados líquidos cujas particularidades tornem inviável o seu lançamento na rede pública de esgotos ou corpos de água, ou exijam para isso soluções economicamente inviáveis em face à melhor tecnologia disponível (ABNT, 2004).

Segundo a Associação Brasileira de Empresas de Limpeza Pública e Resíduos Especiais, em 2017 foram geradas quase 215 mil ton RSU/dia e cerca de $91 \%$ destes resíduos foram coletados. No entanto, $41 \%$ dos resíduos coletados são dispostos de forma inadequada, em lixões e aterros controlados (ABRELPE, 2017). Considerando que na composição gravimétrica média dos RSU coletados no Brasil cerca de 50\% é matéria orgânica com elevada biodegradabilidade, sua disposição em aterros municipais vem se tornando uma fonte de preocupação, uma vez que produz lixiviado e gases cuja dispersão causa variações estruturais no solo e poluição ambiental (MONTEIRO et al., 2001).

Dentre os RSU, destacam-se os lodos gerados nos sistemas de tratamento de água e esgoto, por definição uma mistura de sólidos e semissólidos removidos da corrente líquida no tratamento de esgotos. Apesar desse resíduo representar somente de 1 a $2 \%$, em média, do volume total de esgoto tratado, seu gerenciamento é bastante complexo e demanda custos elevados. Estima-se que até $60 \%$ do custo total do tratamento de esgotos seja proveniente do gerenciamento dos lodos gerados (FOLADORI et al., 2010). Devido ao crescente aumento populacional e, consequentemente, da produção de lodo nas Estações de Tratamento de Esgoto (ETE), a Política Nacional de Resíduos Sólidos (PNRS), contemplada na Lei $n^{\circ}$ 12.305/2010 (BRASIL, 2010), estabeleceu a necessidade de gestão correta desse lodo. A partir da criação da PNRS, foi determinado que os resíduos sólidos devem ser tratados e recuperados por processos tecnológicos disponíveis e economicamente viáveis, antes de sua disposição final.

Uma grande concentração de material orgânico, nitrogenado e fosforado é encontrada nos lodos primário (separado nos decantadores primários) e biológico ou secundário, sendo necessário um tratamento adequado antes de sua disposição final, que envolve processos de adensamento, desaguamento, estabilização e higienização, dependendo do destino final (ANDREOLI et al., 2001). A estabilização da matéria orgânica contida no lodo se faz necessária, podendo ocorrer via processos biológicos anaeróbios ou aeróbios, ou ainda via estabilização química alcalina. Dentre as diversas opções disponíveis para estabilização dos lodos, a digestão anaeróbia é provavelmente a tecnologia mais amplamente utilizada porque apresenta vantagens como o baixo custo de implantação e a geração de metano, um gás com alto poder calorífico que pode ser empregado como fonte energética (CHERNICHARO, 2007).

Os resíduos alimentares também constituem parte da fração orgânica dos RSU provenientes de várias fontes, incluindo plantas de processamento de alimentos, cozinhas comerciais e domésticas, lanchonetes e restaurantes. São compostos principalmente de polímeros de carboidratos (amido, celulose e hemicelulose), lignina, proteínas, lipídeos, ácidos orgânicos, e de uma menor parcela inorgânica (KIRAN et al., 2014), sendo utilizados como matéria-prima de processos fermentativos para produção de vários tipos de bioprodutos de alto valor agregado, como metano, hidrogênio, etanol, enzimas, ácidos orgânicos, biopolímeros e bioplásticos (SHIN et al., 2008). Existem vários métodos disponíveis para o tratamento desses resíduos orgânicos, entretanto a digestão anaeróbia constitui uma abordagem mais promissora (ZHANG et al., 2015; DEEPANRAJ et al., 2017).

O consumo de biodiesel no Brasil vem aumentando desde a implantação da nova Lei Federal $n^{\circ}$ 11.097, de 13 de janeiro de 2005, relacionada à aplicação dos recursos energéticos, que obrigou, a partir de 2008, o acréscimo de biodiesel ao diesel comum. Segundo o Ministério de Minas e Energia, a produção de biodiesel no Brasil chegou ao maior nível nos últimos dez anos. Nos três primeiros meses de 2018 foram registrados 1,13 bilhão de litros, $32 \%$ a mais que no mesmo período de 2016. O Brasil foi o 
segundo maior mercado de biodiesel em 2017, seguindo os Estados Unidos, com 7,4 bilhões de litros (www.brasil.gov.br). Neste mesmo ano, a geração de glicerol bruto (glicerol proveniente da produção de biodiesel sem nenhum pré-tratamento) foi de 375 mil m3 (ANP, 2018), superando muito a demanda de glicerol como matéria prima de processos industriais químicos e farmacêuticos. Uma alternativa para aproveitamento desse resíduo é a produção de biogás via digestão anaeróbia.

A crescente preocupação com a segurança energética, impactos ambientais e aumento do custo de energia para o tratamento de águas residuárias têm restabelecido o processo de digestão anaeróbia como uma das principais tecnologias de produção de energias renováveis (IACOVIDOU et al., 2012). A fim de aumentar o rendimento de metano, a codigestão de lodo com um ou mais substratos tornou-se uma alternativa, tendo em vista que o cossubstrato pode fornecer nutrientes inexistentes ou em baixas concentrações no lodo e, ao mesmo tempo, proporcionar um efeito sinergético positivo no mistura, conduzindo a uma digestão estável e a uma maior produção de biogás (MATAALVAREZ et al., 2014).

A codigestão anaeróbia de lodo de esgoto e fração orgânica de resíduos sólidos (FORSU) é a mais relatada na literatura. Outros cossubstratos, como frutas, resíduos vegetais e de matadouros, glicerol e biomassa de microalgas, também têm sido amplamente estudados. Diversos autores relatam resultados satisfatórios na codigestão de lodo de esgoto com resíduo alimentar (GOU et al., 2014; ZHANG et al., 2016). Outro cossubstrato avaliado atualmente é o glicerol, principal coproduto da produção de biodiesel. Estudos comprovam que a produção de metano pode aumentar na codigestão de lodo com glicerol, por este ser um substrato de elevada biodegradabilidade, de alta disponibilidade e baixo preço (FOUNTOULAKIS et al., 2010; NGHIEM et al., 2014).

Todo resíduo de natureza orgânica é preocupante quanto aos aspectos ambientais relacionados à sua disposição final, e a digestão anaeróbia se apresenta como tecnologia aplicável ao seu tratamento e estabilização. Entretanto, sabe-se que a eficiência do tratamento anaeróbio é passível de comprometimento devido à presença de inibidores (como, por exemplo, concentrações residuais do catalisador alcalino e metanol no glicerol, e altas concentrações de ácidos graxos na degradação de resíduo alimentar). Portanto, o objetivo geral do estudo foi avaliar a eficiência da codigestão anaeróbia para o tratamento de misturas binárias de lodo de esgotos e resíduo alimentar ou glicerol bruto visando ao aumento da produção de metano.

\section{METODOLOGIA}

\subsection{AMOSTRAGEM E CARACTERIZAÇÃO DOS RESÍDUOS}

O lodo de esgoto empregado nos ensaios de codigestão foi proveniente de decantadores secundários de sistemas de lodos ativados em operação no Centro Experimental de Saneamento Ambiental da Universidade Federal do Rio de Janeiro (CESA-UFRJ) e na Estação de Tratamento de Esgotos do Rio de Janeiro. Após coleta na linha de recirculação, os lodos foram caracterizados em termos de umidade (91-97\%), razão sólidos voláteis: sólidos totais $(0,50-0,61)$, relação carbono: nitrogênio $(7-10)$, e potencial de produção de metano $(73-145 \mathrm{~mL} \quad \mathrm{CH} 4 / \mathrm{g}$ DQOremovida).

O resíduo alimentar foi coletado no Restaurante Universitário do Centro de Tecnologia da Universidade Federal do Rio de Janeiro, triturado com adição de água destilada na proporção 1:3 v/v (resíduo: água) em liquidificador, de modo que a umidade da mistura fosse igual à do lodo utilizado. Uma alíquota da mistura obtida (água + restos de comida) foi submetida a uma caracterização físico-química, sendo o restante armazenado em freezer $\left(-20^{\circ} \mathrm{C}\right)$ até o momento de uso.

O glicerol bruto foi proveniente de usina de biodiesel da Petrobras Biocombustíveis S.A. (PBIO), localizada em Montes Claros-MG. Esta usina utiliza uma mistura de sebo e óleo de soja como matéria-prima e a transesterificação é conduzida com metanol, hidróxido de sódio como catalisador e ácido clorídrico como agente neutralizante. A amostra foi coletada após decantação da fase pesada e recuperação do álcool presente no glicerol, sendo denominada glicerol bruto e caracterizada antes do uso. Para os ensaios de codigestão, o glicerol bruto foi diluído 10 vezes antes de sua adição ao lodo, para uma melhor manipulação e homogeneização na mistura. 


\subsection{EXPERIMENTOS DE CODIGESTÃO EM FRASCOS PENICILINA}

A codigestão de lodo com resíduo alimentar e glicerol bruto foi avaliada separadamente em dois ensaios: o primeiro foi conduzido com a mistura de lodo e resíduo alimentar (RA) e o segundo com a mistura de lodo e glicerol bruto (GB). Ambos os ensaios foram conduzidos em frascos penicilina de $100 \mathrm{~mL}$ com volume útil de 50 e $90 \mathrm{~mL}$ Diferentes percentagens de RA $(10,15,20$ e $25 \% \mathrm{v} / \mathrm{v})$ e GB (1, 0,5 e 0,8 \% v/v) foram adicionadas ao lodo de esgoto. $\mathrm{O} \mathrm{pH}$ inicial das misturas foi corrigido, em todos os frascos, com $\mathrm{NaHCO} 3$ para 7,5. Após a preparação das misturas binárias, os frascos eram fechados e acoplados a seringas plásticas de $60 \mathrm{~mL}$, para medição do volume de biogás produzido, e incubados a $30^{\circ} \mathrm{C}$, sem agitação, até estabilização da produção de biogás. Os ensaios foram conduzidos em 4 réplicas por 30-42 dias.

Alíquotas iniciais eram tomadas para análise do $\mathrm{pH}$ e concentrações iniciais de Sólidos Voláteis, de acordo com Standard Methods (APHA, 2005). A quantificação de glicerol foi realizada de acordo com Bondiolli e Bella (2005). Após estabilização da produção de biogás, os frascos eram abertos e realizadas as medidas finais dos mesmos parâmetros iniciais. No segundo ensaio, DQO solúvel, alcalinidade total (AT) e ácidos voláteis totais (AVT) também foram mensurados, empregando métodos potenciométrico (RIPLEY et al., 1986) e titulométrico (DILALLO e ALBERTSON, 1961), respectivamente. Amostras do biogás acumulado eram tomadas e submetidas à cromatografia em fase gasosa para quantificação de metano.

\section{RESULTADOS E DISCUSSÃO}

\subsection{CARACTERIZAÇÃO DOS RESÍDUOS}

Ambos os lodos apresentaram variação da concentração de sólidos entre os lotes coletados, possivelmente devido a variações na operação da estação de uma coleta para outra, e relação C:N abaixo da faixa adequada para a digestão anaeróbia, entre 10 e 30 (WEILAND, 2001). Segundo MataAlvarez et al. (2014), lodos de esgoto são caracterizados por uma relação C:N relativamente baixa e elevada capacidade tampão. Portanto, combinam bem com substratos contendo grandes quantidades de matéria orgânica facilmente biodegradável e baixos valores de alcalinidade.

Na Tabela 1 é apresentada a caracterização de uma coleta do resíduo alimentar e do glicerol bruto utilizados. Verifica-se que o RA apresentava umidade elevada, $\mathrm{pH}$ ácido e relação SV/ST de 0,94, valor próximo ao encontrado por Gou et al. (2014) e indicativa de um elevado conteúdo de matéria orgânica. A concentração de fósforo era muito baixa em relação ao carbono (C:P de 17200), indicando forte deficiência de fósforo para a digestão anaeróbia. Já a concentração de nitrogênio era maior que a necessária, em relação ao carbono (C:N de 6,5), para a digestão anaeróbia. Quanto ao GB, a caracterização revelou que, além do glicerol, o resíduo também apresenta alta concentração de salinidade e baixa concentração de metanol, - que pode ser prejudicial e benéfico, respectivamente, para a digestão anaeróbia.

Tabela 1. Características do resíduo alimentar e do glicerol bruto.

\begin{tabular}{l|c|l|c|}
\multicolumn{3}{c}{ Resíduo Alimentar } & \multicolumn{2}{c|}{ Plicerol Bruto } \\
Parâmetro & Valor & Umidade $(\%)$ & Valor \\
\hline $\mathrm{pH}$ & 5,2 & DQO $(\mathrm{mg} / \mathrm{L})$ & 1119 \\
\hline Umidade $(\%)$ & 73,2 & Carbono $(\mathrm{g} / \mathrm{L})$ & 411 \\
\hline Carbono $(\mathrm{mg} / \mathrm{g})^{\mathrm{a}}$ & 516,0 & Glicerol $(\mathrm{g} / \mathrm{L})$ & 93,2 \\
\hline Nitrogênio $(\mathrm{mg} / \mathrm{g})^{\mathrm{a}}$ & 80,0 & Salinidade $(\mathrm{g} \mathrm{Cl} / \mathrm{L})$ & 37,1 \\
\hline Fósforo $(\mathrm{mg} / \mathrm{g})^{\mathrm{a}}$ & 0,03 & Metanol $(\mathrm{mg} / \mathrm{L})$ & 19 \\
\hline${\text { Carboidratos }(\mathrm{mg} / \mathrm{g})^{\mathrm{a}}}^{\mathrm{a}}$ & 83,3 & & \\
\hline Proteínas $(\mathrm{mg} / \mathrm{g})^{\mathrm{a}}$ & 97,7 & & \\
\hline Óleos e graxas $(\mathrm{mg} / \mathrm{g})^{\mathrm{a}}$ & 260,4 & & \\
\hline Sólidos Totais $(\mathrm{mg} / \mathrm{g})^{\mathrm{b}}$ & 267,68 & & \\
\hline Sólidos Fixos $(\mathrm{mg} / \mathrm{g})^{\mathrm{b}}$ & 16,31 & & \\
Sólidos Voláteis $(\mathrm{mg} / \mathrm{g})^{\mathrm{b}}$ & 251,37 & & \\
\hline
\end{tabular}




\subsection{CODIGESTÃO DE LODO E RESÍDUO ALIMENTAR (RA)}

Os resultados demonstraram que com a adição de baixas porcentagens de RA ao lodo e uma maior alcalinidade inicial (maior adição de $\mathrm{NaHCO}_{3}$ ), o $\mathrm{pH}$ se manteve na faixa adequada para metanogênese $(7,2-7,6)$ nas misturas com o lodo. Em todas as condições testadas, a porcentagem de metano, bem como a redução de SV e a produção específica de metano (PEM), foram maiores em relação ao controle (Tabela 2). Comparando as quatro condições testadas, a mistura com adição de $10 \%$ de RA apresentou melhor resultado, com um aumento de 1,3 vezes da PEM em relação ao controle e uma redução de SV de 67,2 \% (Figura 1).

Tabela 2. Resultados da codigestão de lodo de esgoto com baixas percentagens de RA.

\begin{tabular}{|c|c|c|c|c|c|c|}
\hline $\begin{array}{c}\text { Mistura } \\
\text { Lodo:RA } \\
(\% \text { v/v) }\end{array}$ & $\begin{array}{c}\mathrm{pH} \\
\text { inicial }\end{array}$ & $\begin{array}{c}\mathrm{pH} \\
\text { final }\end{array}$ & $\begin{array}{c}\text { Remoção SVa } \\
(\%)\end{array}$ & $\begin{array}{c}\text { Biogás }{ }^{a, b . c} \\
(m L)\end{array}$ & $\begin{array}{c}\mathrm{CH}_{4}{ }^{\mathrm{a}, \mathrm{b}, \mathrm{c}} \\
(\%)\end{array}$ & PEM $^{\mathrm{C}}$ \\
\hline $100: 0$ & 7,5 & 7,0 & $51,1 \pm 8,5$ & $17,0 \pm 2,8$ & $67,0 \pm 1,7$ & $137,6 \pm 25,4$ \\
\hline $90: 10$ & 7,5 & 7,3 & $67,2 \pm 4,8$ & $67,3 \pm 1,5$ & $76,1 \pm 1,6$ & $184,2 \pm 17,4$ \\
\hline $85: 15$ & 7,5 & 7,2 & $59,2 \pm 4,7$ & $72,0 \pm 17,1$ & $75,4 \pm 2,5$ & $147,6 \pm 13,8$ \\
\hline 80:20 & 7,5 & 7,3 & $57,8 \pm 7,4$ & $101,8 \pm 18,3$ & $75,4 \pm 3,7$ & $167,9 \pm 24,1$ \\
\hline $75: 25$ & 7,5 & 7,2 & $51,9 \pm 7,4$ & $100, \pm 4,8$ & $73,9 \pm 3,8$ & $120,5 \pm 22,8$ \\
\hline
\end{tabular}

Figura 1. Comparação da PEM, \% SV removidos e \% $\mathrm{CH}_{4}$ no biogás em misturas de lodo secundário com diferentes percentuais de resíduo alimentar.

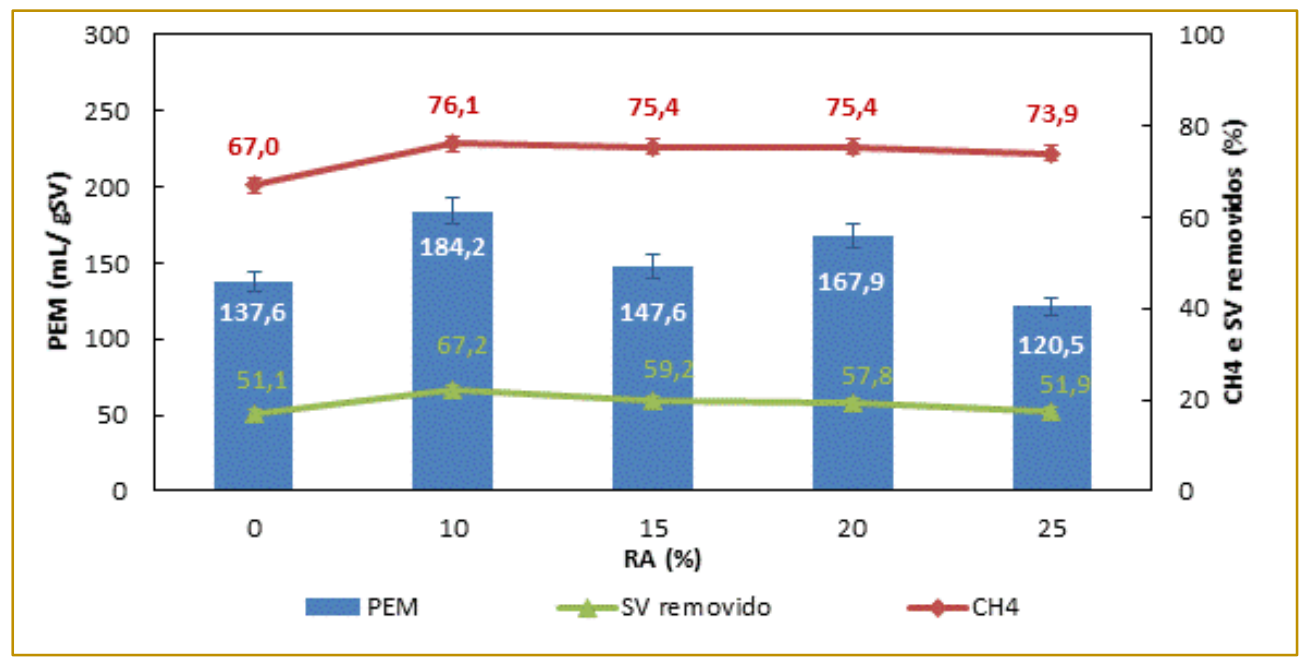

A Figura 2 indica que a adição de RA ao lodo aumentou consideravelmente o volume de biogás até o $30^{\circ}$ dia para todas as condições, estabilizando em seguida. Enquanto no ensaio Controle (com 100\% lodo) atingiu-se volumes de biogás de somente $17 \mathrm{~mL}$ após 42 dias de digestão a $30^{\circ} \mathrm{C}$, no ensaio com $20 \%$ de RA o volume final de biogás atingiu 102 mL após o mesmo período de digestão.
Esses resultados estão de acordo com o reportado por Luostarinen et al. (2009) e Kim e Kang (2015), que também alcançaram a estabilização da produção de biogás aos 30 dias de codigestão de lodo de esgoto com diferentes porcentagens de lodo proveniente de indústria de processamento de carne e de codigestão de resíduo alimentar com biomassa de microalgas, respectivamente. 
Figura 2. Volume de biogás $\left(30^{\circ} \mathrm{C}\right)$ acumulado com lodo puro (100\% lodo) e misturas de lodo e baixas percentagens de RA.

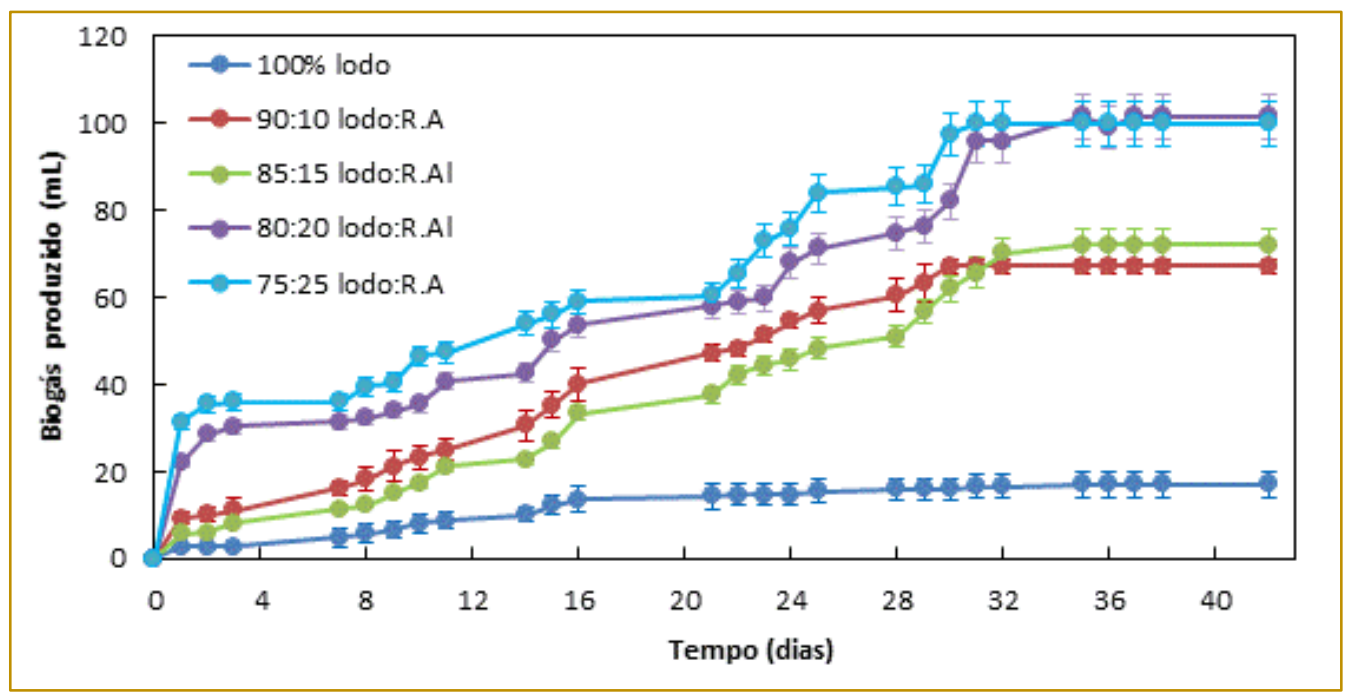

\subsection{ENSAIOS DE CODIGESTÃO DE LODO E GLICEROL BRUTO (GB)}

Em ensaios preliminares, a adição de 1\% (v/v) de GB ao lodo de esgoto resultou em inibição da produção de biogás, provavelmente devido à elevada salinidade, verificando-se uma pequena porcentagem de metano no biogás (16,5 - 22,5\%), menor que a obtida no controle $(26,4 \%)$. A instabilidade no processo de codigestão com a adição de 1\% (v/v) de glicerol ao lodo já foi reportada por diversos autores na literatura (FOUNTOULAKIS et al.,
2010; SILVESTRE et al., 2015). Entretanto, com a adição de menores porcentagens de glicerol verificou-se o aumento do volume de biogás produzido com o tempo (Figura 3). A adição de $0,5 \%$ e $0,8 \%$ (v/v) de GB apresentou resultados similares, com maior velocidade inicial de produção $(2,3 \mathrm{~mL} / \mathrm{d})$ e maior volume final de biogás $(39 \mathrm{~mL}) \mathrm{com}$ $0,8 \%$, em comparação ao controle (100\% lodo), que apresentou valores de 1,3 $\mathrm{mL} / \mathrm{d}$ e $30,5 \mathrm{~mL}$.

Figura 3. Volume acumulado de biogás na digestão de lodo de esgoto sem (100\% lodo) e com adição de baixas concentrações de glicerol bruto.

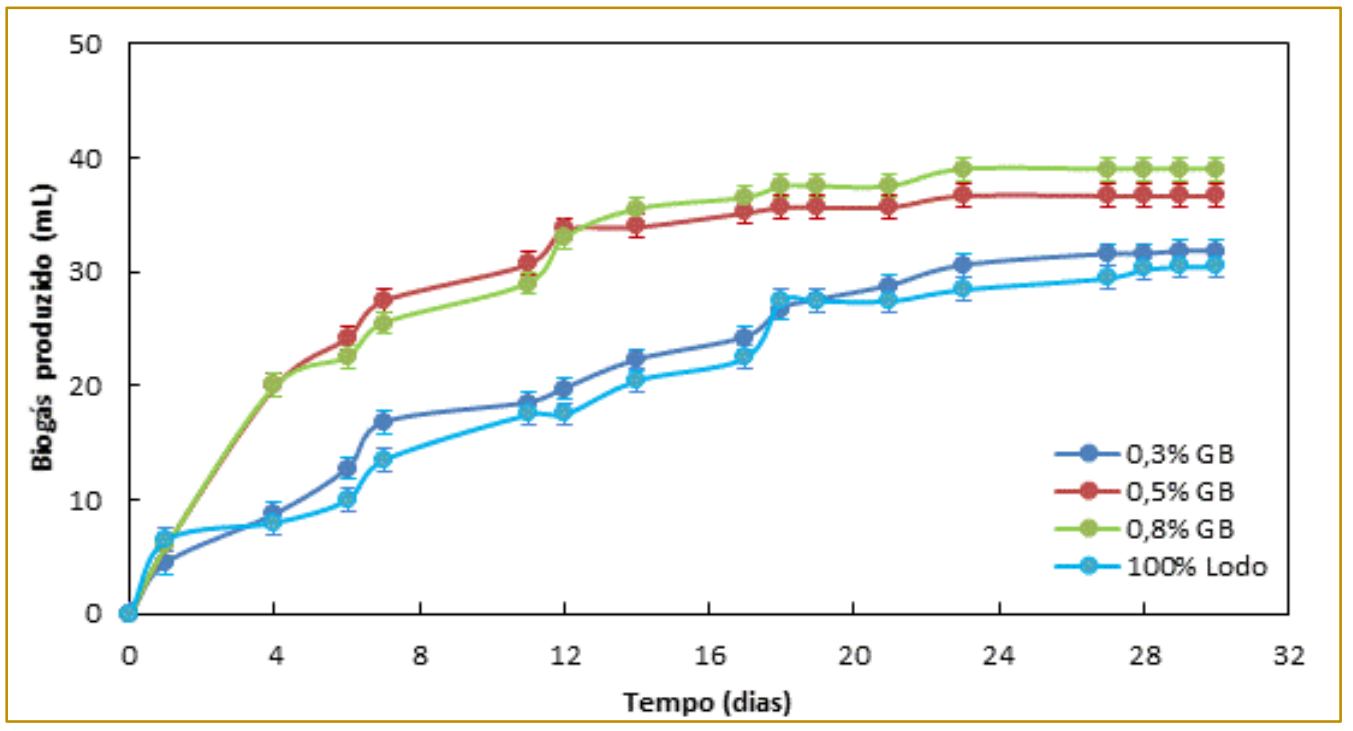


A adição de GB abaixo de 1\% v/v e o ajuste do $\mathrm{pH}$ inicial para valor ligeiramente alcalino $(7,5)$ permitiu o tamponamento da mistura e a manutenção de uma baixa relação AVT/AT $(0,2-0,3)$ ao final do processo de codigestão. Comparando a adição de 0,5 e 0,8\% de GB ao lodo, a adição de 0,5\% apresentou melhor resultado, praticamente dobrando a PEM em comparação ao controle. O valor da PEM para essa condição foi de $78,4 \mathrm{~mL} \mathrm{CH} / \mathrm{g} \mathrm{SV}$ aplicados contra $45,4 \mathrm{~mL} \mathrm{CH} \mathrm{CH}_{4} / \mathrm{g} \mathrm{SV}$ aplicados no controle (Tabela 3).

Nighiem et al. (2014), na codigestão de lodo com 0,25 e $0,5 \%(v / v)$ de glicerol em reator batelada, reportaram valores de PEM de 0,67 e $0,33 \quad \mathrm{~m}^{3} \quad \mathrm{CH}_{4} / \mathrm{L}$ glicerol aplicado, respectivamente. Assim como no presente trabalho, os autores também notaram instabilidade no processo com a adição de $1 \%(\mathrm{v} / \mathrm{v})$ de GB. Em relação à PEM, verificouse no estudo de Nighiem et al. (2014) que esta era tanto maior quanto menor a porcentagem de glicerol adicionado, diferente do que ocorreu no presente estudo. Assim, conclui-se que valores acima ou abaixo de 0,5\% de GB adicionado contribuem para uma menor PEM, apesar desta ser maior em relação ao controle para todas as percentagens abaixo de $1 \%(\mathrm{v} / \mathrm{v})$ testadas.

Tabela 3. Resultados da codigestão de lodo de esgoto com glicerol bruto.

\begin{tabular}{|c|c|c|c|c|c|c|c|}
\hline $\begin{array}{c}\mathrm{GB} \\
(\% \mathrm{v} / \mathrm{v})\end{array}$ & $\begin{array}{l}\mathrm{pH} \\
\text { final }\end{array}$ & $\begin{array}{c}\text { SVi } \\
\text { (mg/L) }\end{array}$ & $\begin{array}{l}S V f^{a, b, c} \\
(m g / L)\end{array}$ & $\begin{array}{l}\text { Remoção } \\
\text { SV }(\%)^{a, b}\end{array}$ & $\begin{array}{c}\text { Biogás }{ }^{a, b, c} \\
(m L)\end{array}$ & $\begin{array}{c}\mathrm{CH}_{4}^{\mathrm{a}, \mathrm{b}, \mathrm{c}} \\
(\%)\end{array}$ & PEM $^{c}$ \\
\hline 0 & 7,0 & 8320 & 5655 & 32,0 & 30,5 & 61,9 & 45,4 \\
\hline 0,3 & 7,5 & 8010 & 6300 & 21,3 & 31,8 & 78,2 & 62,0 \\
\hline 0,5 & 7,4 & 7880 & 6350 & 19,4 & 36,8 & 84,1 & 78,4 \\
\hline 0,8 & 7,4 & 8030 & 6790 & 15,4 & 39,0 & 65,5 & 63,6 \\
\hline
\end{tabular}

${ }^{a}$ médias de 4 réplicas. ${ }^{b}$ valores finais aos 30 dias. ${ }^{\mathrm{c}}$ biogás medido a $30^{\circ} \mathrm{C} / 1 \mathrm{~atm}$. $\mathrm{PEM}=$ produção específica de metano $\left(\mathrm{mL} \mathrm{CH}_{4} / \mathrm{g} \mathrm{SV}\right.$ apliçados $)$.

Apesar do aumento da produção específica de metano (PEM) para misturas com adição de glicerol entre 0,3 e 0,8\% v/v em relação ao controle, a remoção de SV ainda foi baixa, com valor máximo de $21,3 \%$ para $0,3 \% \mathrm{v} / \mathrm{v}$ de GB contra 32,0\% no controle (Tabela 3). Esses valores estão de acordo com o reportado por Athanasoulia et al. (2014), que reportaram redução de SV de $36 \%$ para o controle e $24 \%$ na mistura de lodo e $3 \% \mathrm{v} / \mathrm{v}$ de glicerol, em reator contínuo do tipo CSTR. O fato da redução de SV ser maior no controle que nas misturas lodo e glicerol pode ser devido à maior disponibilidade de carbono proveniente do glicerol, contribuindo para a manutenção da atividade da biomassa e reduzindo a estabilização dos SV (FOUNTOULAKIS et al., 2010).

\section{REFERÊNCIAS}

[1] ABNT. Associação Brasileira de Normas Técnicas. ABNT NBR 9050:2004, 2004.

[2] ABRELPE. Associação Brasileira de Empresas de Limpeza Pública e Resíduos Especiais. Panorama dos Resíduos Sólidos no Brasil. São Paulo: ABRELPE, 2017.

\section{CONCLUSÕES}

Na codigestão anaeróbia de misturas binárias de lodo e resíduo alimentar (RA) em escala de bancada, O alto percentual de SV, carboidratos e proteínas do RA favoreceu a produção de metano. A adição de menores proporções de RA (10 a 25 \% v/v) ao lodo, com correção do $\mathrm{pH}$ inicial para 7,5, permitiu melhor tamponamento e maior remoção de SV e PEM em todas as condições testadas. A adição de proporções < $1 \%(\mathrm{v} / \mathrm{v})$ de $\mathrm{GB}$ ao lodo, reduziu a interferência da salinidade e permitiu aumento da produção de metano, sem prejudicar a estabilização da mistura. A codigestão anaeróbia das misturas binárias pode contribuir para o aumento da produção de metano nos digestores de lodo de ETE, viabilizando seu aproveitamento energético.

[3] ANDREOLI, C.V.; VON SPERLING, M.; FERNANDES. F. Lodos de esgotos - Tratamento e Disposição Final. Rio de Janeiro: ABES. 484 p., 2001.

[4] ANP. Agência Nacional de Petróleo, Gás Natural e Biocobustíveis. Anuário Estatístico Brasileiro do Petróleo, Gás Natural e Biocobustíveis, 2018. 
[5] APHA. American Public Health Association. Standard Methods for the Examination of Water and Wastewater, 18th ed., New York, 2005.

[6] ATHANASOULIAR, E.; MELIDIS, P.; AIVASIDIS, A. Co-digestion of sewage sludge and crude glycerol from biodiesel production. Renewable Energy, v. 62, p. 73-78, 2014.

[7] BONDIOLI, P.; BELLA L.D. An alternative spectrophotometric method for the determination of free glycerol in biodiesel. European Journal of Lipid Science and Technology, v. 107, p. 153-157, 2005.

[8] BRASIL. Lei no 12.305, de 2 de agosto de 2010. Política Nacional de Resíduos Sólidos. Brasília: Governo Federal, 2010.

[9] CHERNICHARO, C.A.L. Reatores Anaeróbios. Departamento de Engenharia Sanitária e Ambiental, Universidade Federal de Minas Gerais, Belo Horizonte, MG, 379 p., 2007.

[10] DEEPANRAJ, B.; SIVASUBRAMANIAN, V.; JAYARAJ, S. Effect of substrate pretreatment on biogas production through anaerobic digestion of food waste. International Journal of Hydrogen Energy, v. 42, p. 26522-26528, 2017.

[11] DILALLO, R.; ALBERTSON, O.R. Volatile acids by direct titration. Journal of Water Pollution Control Federation, v. 23, p. 356-365, 1961.

[12] FOLADORI, P.; ANDREOTTOLA, G.; ZIGLIO, G. Sludge reduction technologies in wastewater treatment plants. IWA Publishing, London, 2010.

[13] FOUNTOULAKIS, M.S.; PETOUSI, I.; MANIOS, T. Co-digestion of sewage sludge with glycerol to boost biogas production. Waste Management, v. 30, p. 1849-1853, 2010.

[14] GOU, C.; YANG, Z.; HUANG, J.; WANG, $H_{\text {.; }} X U, H$.; WANG, L. Effects of temperature and organic loading rate on the performance and microbial community of anaerobic co-digestion of waste activated sludge and food waste. Chemosphere, v. 105, p. 146-151, 2014.

[15] IACOVIDOU, E.; OHANDJA, D.G.; VOULVOULIS, N. Food waste co-digestion with sewage sludge - Realising its potential in the UK. Journal of Environmental Management, v. 112, p. 267-274, 2012.

[16] KIM, J.; KANG, C.M. Increased anaerobic production of methane by co-digestion of sludge with microalgal biomass and food waste leachate. Bioresource Technology, v. 189, p. 409-412, 2015.
[17] KIRAN, E.; TRZCINSKI, A.P.; NG, W.J.; LIU, Y. Bioconversion of food waste to energy: A review. Fuel, v. 134, p. 389-399, 2014.

[18] LUOSTARINEN, S.; LUSTE, S.; SILLANPÄÄ, M. Increased biogas production at wastewater treatment plants through co-digestion of sewage sludge with grease trap sludge from a meat processing plant. Bioresource Technology, v. 100, p. 79-85, 2009.

[19] MATA-ALVAREZ, J.; DOSTA, J.; ROMEROGÜIZA, M.S.; FONOLL, X.; PECES, M.; ASTALS, S. A critical review on anaerobic co-digestion achievements between 2010 and 2013. Renewable and Sustainable Energy Reviews., v. 36, p. 412427,2014

[20] MONTEIRO, J.H.P.; FIGUEREDO, C.E.M.; MAGALHÃES, A.F.; MELO, M.A.F.; BRITO, J.C.X.; ALMEIDA,, T.P.F., MANSUR, G.L. Manual de Gerenciamento Integrado de Resíduos Sólidos. Rio de Janeiro: IBAM. 200p., 2001.

[21] NGHIEM, L.D.; NGUYEN, T.T.; MANASSA, P.; FITZGERALD, S.K.; DAWSON, M.; VIERBOOM, S. Co-digestion of sewage sludge and crude glycerol for on demand biogas production. International Biodeterioration \& Biodegradation, v. 95, p. 160-166, 2014.

[22] RIPLEY, L.E.; BOYLE, W.C.; CONVERSE, J.C. Improved alkalimetric monitoring for anaerobic digester of high-strength wastes. Journal of Water Pollution Control Federation, v. 58, p. 406-411, 1986.

[23] SHIN, J.D.; HAN, S.S.; EOM, K.C.; SUNG, S.H.; PARK, S.W.; KIM, H.O. Predicting methane production potential of anaerobic co-digestion of swine manure and food waste. Environmental Energy Research, v. 13, p. 93-97, 2008.

[24] SILVESTRE, G.; FERNÁNDEZ, B.; BONMATÍ, A. Addition of crude glycerine as strategy to balance the $\mathrm{C} / \mathrm{N}$ ratio on sewage sludge thermophilic and mesophilic anaerobic codigestion. Bioresource Technology, v. 193, p. 377385,2015

[25] ZHANG, C.; SU, H.; WANG, Z.; TAN, T.; QIN, P. Biogas by semi-continuous anaerobic digestion of food waste. Applied Biochemistry and Biotechnology, v. 175, p. 3901-3914, 2015.

[26] ZHANG, J.; LV, C.; TONG, J.; LIU, J.; LIU, J.; YU, D.; WANG, Y.; CHEN, M.; WEI, Y. Optimization and microbial community analysis of anaerobic codigestion of food waste and sewage sludge based on microwave pretreatment. Bioresource Technology, v. 200, p. 253-261, 2016. 


\section{Bapítulo 14}

\section{POTENCIAL BIOTECNOLÓGICO DE BACTÉRIAS ISOLADAS DE BIODIGESTOR ANAERÓBIO}

Angela Cristina Mélo-Schlub

Vânia Kelly da Silva

Alessandra Lee Barbosa Firmo

Leonor Alves de Oliveira da Silva

Resumo: A captação do gás metano produzido nos aterros sanitários é uma alternativa energética sustentável em crescente expansão no mundo, pois relaciona muito bem os aspectos econômicos gerados pela venda deste gás com os aspectos de ordem ambiental. A instalação de aterros sanitários visando a captação e utilização do biogás como fonte energética, diminuirá a emissão na atmosfera dos Gases Efeito Estufa (GEE's), além de reduzir o volume dos resíduos sólidos urbanos gerados e depois entrepostos nos aterros. O presente estudo avalia o potencial enzimático das bactérias isoladas em biodigestor anaeróbico de resíduos sólido urbanos.

A pesquisa foi desenvolvida com dozes (12) linhagens bacterianas isoladas do biorreator preenchido de resíduo sólido urbano (RSU). As linhagens de bactérias foram submetidas aos testes bioquímicos, as provas morfológicas e as análises enzimáticas. O Índice enzimático (I.E.) foi utilizado para avaliar qualitativamente a capacidade dos isolados bacterianos em degradar os substratos de acordo com a enzima estudada.

O resultado obtido demostrou para cada linhagem a sua capacidade na degradação enzimática. Nenhuma das dozes linhagens bacterianas foi capaz de excretar todas as cinco enzimas avaliadas, nenhuma foi capaz de degradar o amido, sendo assim a linhagem foi avaliada segundo o seu maior I.E. para cada substrato.

Palavras-chave: Biorreator anaeróbico. Resíduo Sólido Urbano. Gás Metano. Enzimas hidrolíticas. 


\section{INTRODUÇÃO}

Grande parte da comunidade científica afirma que as mudanças climáticas são causadas pelo uso de fontes tradicionais, como o carvão e o petróleo, e isto é preocupante. Segundo o Painel Intergovernamental sobre Mudanças Climáticas, entre 2000 e 2010 as emissões de gases de efeito estufa na atmosfera cresceram rapidamente e a previsão da temperatura média global é de um aumento de $5^{\circ} \mathrm{C}$ até 2100 (IPCC, 2014).

A procura de alternativas tecnológicas mais respeitosas do meio ambiente estão cada vez mais presentes na sociedade. A produção de biogás é uma delas e é com este enfoque que o presente trabalho foi baseado, mais precisamente os gases oriundos de aterros sanitários urbanos. O biogás produzido em aterro sanitário será captado para a geração de energia, seja na forma de eletricidade ou de calor, ou seja como gás natural. Além de ser uma fonte econômica, o seu reaproveitamento evitará a sua liberação para a atmosfera, reduzindo assim a sua participação nas emissões de GEE's e do volume físico dos resíduos sólidos.

A potência das instalações industriais que produzem biogás no mundo aumentará entre 2012 até 2016 de 4,7 GWe à 7,3 GWe e o crescimento do número de instalações passará de 9.700 unidades a 13.000 unidades, dados apresentados na terceira edição de O biogás em energia (2012/2013), relatado pela empresa de análise Ecoprog e do Instituto Fraunhofer. A Alemanha é o exemplo atual na recuperação do biogás, das 10.000 instalações mundiais de biogás com capacidade de cerca de 5 GWe ela possui $2 / 3$, ela será seguida nos próximos 5 anos pela Itália, Reino Unido, a França, EUA, Canadá, China, Índia e Japão (GALEFFI, 2013).

De acordo com o estudo "Panorama dos Resíduos Sólidos Brasil 2011" da Associação Brasileira de Empresas de Limpeza Pública e Resíduos Especiais (ABRELPE) no Brasil, estimou-se a geração de aproximadamente 62 milhões de toneladas de resíduos sólidos urbanos. Esta quantidade gerada somente $90 \%$ foi coletada, o que equivale a $180 \mathrm{mil}$ toneladas por dia, destes resíduos coletados, $58 \%$ foram destinados a aterros sanitários, $24 \%$ em aterros controlados e 17\% em lixões. Os aterros controlados e os lixões não possuem o conjunto de sistemas e medidas necessárias para a proteção do meio ambiente contra as degradações sofridas por tal prática, mas mesmo assim, recebe 75 mil toneladas diárias (Atlas Brasileiro de Emissões de GEE).

A Política Nacional de Resíduos Sólidos (PNRS), Lei 12.305/10, com seus princípios, diretrizes e metas tenta inverter o estado atual que o Brasil vive em relação aos seus rejeitos sólidos. Segundo, o Instituto Brasileiro de Defesa do Consumidor (IDEC) em dezembro de 2014, o prazo de encerramento dos lixões e a destinação final ambientalmente correta dos rejeitos que estava prevista para agosto de 2014 foi estendido para 2018 por vários motivos operacionais e financeiros que os Municípios e os Estados alegaram.

Os Municípios serão por lei obrigados à entrarem em conformidade. Estas mesmas entidades públicas administrativas podem incluir no seu plano de gestão urbano, o aproveitamento energético do biogás com a construção dos aterros sanitários.

Segundo, o BLOG BGS (2013), não é de hoje que o biogás é utilizado como fonte de energia, no início de 1800, Louis Pasteur vislumbrou pela primeira vez a possibilidade de utilizar o gás produzido pela decomposição da matéria orgânica como combustível para sistemas de aquecimento e iluminação urbana. Em 1857 foi construída a primeira instalação destinada a produzir e utilizar o biogás em grande escala em um hospital para portadores de hanseníase de Bombaim, na Índia.

O biogás como seu próprio nome já indica, tem origem em um processo biológico. Quando a matéria orgânica é degrada por micro-organismos em ausência de oxigênio (meio anaeróbio) é produzido um gás (biogás), energia em forma de calor e biomassa.

A matéria orgânica degradada em anaerobiose produz o metano (50\%-75\% em volume) e o dióxido de carbono (25\%-50\% em volume). O biogás contém também pequenas quantidades de hidrogênio, sulfeto de hidrogênio, amônia e outros gases traços (KALTSCHMITT et al, 2001).

Em um ambiente anaeróbio criado artificialmente que chamamos de biorreator, o crescimento de bactérias anaeróbias é favorecido de maneira controlada, degradando a matéria orgânica introduzida e produzindo o biogás. A composição do biogás dependerá do tipo de substrato à ser 
degradado, da técnica e da tecnologia utilizadas. Por isto existem vários sistemas de digestão anaeróbia no mercado e outras em estudo (KALTSCHMITT et al, 2001).

As enzimas que catalisam as reações químicas, tais como da degradação anaeróbia, são polímeros biológicos. A presença e a manutenção de um conjunto completo e equilibrado de enzimas são essenciais para degradar os nutrientes que fornecem energia e blocos químicos de construção. Como todos os catalisadores, as enzimas não se consomem nem se alteram permanentemente durante sua participação na reação. Além de altamente eficazes, elas são seletivas. A compreensão do funcionamento das enzimas no processo de degradação em anaerobiose nos fornece valiosa contribuição de informações para tornar o processo eficaz e eficiente (VENTURA, 1999).

A formação do biogás passa por vários estágios de degradação bacteriana, coordenadas entre si para que o processo ocorra adequadamente.

O primeiro estágio ocorre a hidrólise dos compostos orgânicos complexos, ( carboidratos, proteína e lipídeos em substâncias menos complexas (açúcares, aminoácidos e ácidos graxos). Nesta etapa participam bactérias hidrolíticas que liberam enzimas responsáveis nesta etapa (Amaral, 2014).

O produto produzido pelas bactérias hidrolíticas, serão por sua vez decomposto pelas bactérias acidogênicas em ácidos graxos de cadeia curta (ácido acético, propiônico e butírico), dióxido de carbono, hidrogênio e pequenas quantidades de ácido lático e álcoois. Os tipos de compostos formados nesse estágio, chamado de fase acidogênica, dependem da concentração do hidrogênio intermediário (Amaral, 2014)

No terceiro estágio chamado de acetogênese, o processo de formação de ácido acético dependem das bactérias acetogênicas que irão converter o produto produzido pelas acidogênicas em ácido acético, hidrogênio e dióxido de carbono. A consequência é o acumulo de ácidos orgânicos que inibem a metanogênese. A necessidade de boa associação das bactérias acetogências e as arqueas metanogênicas. Durante a formação do metano, as arqueas consomem hidrogênio e dióxido de carbono, promovendo um meio propício para as bactérias acetogênicas (Amaral, 2014).

No último estágio, fase metanogênica, as arqueos metanogênicas estritamente anaeróbias convertem principalmente o ácido acético, o hidrogênio e o dióxido de carbono em metano. Os metanógenos hidrogenotróficos produzem metano a partir de hidrogênio e dióxido de carbono, e os metanógenos acetoclásticos a partir da redução de ácido acético (AMARAL, 2004).

Todo o processo de digestão anaeróbia envolve, como foi detalhado anteriormente, vários tipos de bactérias, cada uma com suas próprias exigências. Para que o sistema funcione da melhor maneira possível, segundo os objetivos programados, é necessário chegar a um meio termo em relação aos vários aspectos físico-químicos, tais como: $\mathrm{pH}$ vizinho da neutralidade $(6,5-$ 8,5); potencial de oxido-redução bem baixo (300-400mV) e a temperatura para as termofilas $\left(45-65^{\circ} \mathrm{C}\right.$, cujo o ótimo $55^{\circ} \mathrm{C}$ ), as mesófila $\left(25-45^{\circ} \mathrm{C}\right.$, cujo ótimo $\left.37^{\circ} \mathrm{C}\right)$ e psicrófials $\left(5-25^{\circ} \mathrm{C}\right)$. Vários micro-nutrientes também são importantes para o bom funcionamento da digestão anaeróbia (níquel, magnésio, cálcio, sódio, bário, cobalto, e outros). A relação DCO/N/P aceitável é de 600/7/1 (Mata, 2002).

\section{MATERIAL E MÉTODOS}

O projeto de pesquisa foi realizado no Laboratório de Microbiologia Ambiental e Industrial (LAMAI) na Universidade Federal de Pernambuco. Todo o trabalho foi desenvolvido com dozes (12) linhagens bacterianas isoladas do biorreator preenchido de resíduo sólido urbano (RSU), estes isolados foram conservadas e nomeadas de T1, T2, T3, T5, T6, T9, T11, T13, T16, T17, T18 e T19.

Foram realizados testes bioquímicos, prova morfológica e análises enzimáticas nas doze linhagens bacterianas. Cada linhagem foi repicada em meio Ágar Nutritivo (AN) em pH 7,0 e incubadas a $30^{\circ} \mathrm{C}$ por 24hs. Após o crescimento bacteriano cada linhagem foi semeada em meios enzimáticos para detectar as seguintes enzimas hidrolíticas, xilanases, celulases, amilases, proteases e pectinases.

A determinação qualitativa da atividade enzimática foi realizada em triplicata por meio do método de "cup-plate" modificado, em meios de cultura sólido contendo 20g/L de 
ágar e $10 \mathrm{~g} / \mathrm{L}$ do substrato indutor como fonte de carbono, os quais foram: amido para amilase, carboximetilcelulose (CMC) para celulase, gelatina para protease e xilano de birchwood para xilanase e pectina cítrica para pectinase. Em seguida foram incubados a aproximadamente $30^{\circ} \mathrm{C}$ por 24 horas, sendo acompanhando a cada 12 horas.

A seleção das linhagens bacterianas produtores das referidas enzimas foram visualizadas com formação de halos de degradação enzimática, com a adição de soluções corantes no meio de cultivo de acordo com a enzima analisada: solução de iodo a $0,1 \mathrm{~N}$ ou vapores de iodo para amilase; vermelho congo a $0,1 \%$ para celulase e xilanase. A protease não necessita de solução corante, a medida que o gelatina é degradado pela enzima o halo enzimático fica bem visível a olho nu e solução de lugol para pectinases. Com o aparecimento de halos, a atividade hidrolítica das linhagens bacterianas foram estimadas semiquantitativamente, usando um índice enzimático (IE), o qual é expresso pela relação do diâmetro médio do halo de degradação e do diâmetro do cupplate (HANKIN, L. e ANAGNOSTAKIS, S. L. 1975).

\section{RESULTADOS E DISCUSSÃO}

As provas bioquímicas são utilizadas para identificar as bactérias através de suas características metabólicas reveladas por determinados reagentes. Neste estudo foram utilizados os testes de Peróxido de Hidrogênio $\left(\mathrm{H}_{2} \mathrm{O}_{2}\right)$ à $3 \%$ e Hidróxido de Potássio $(\mathrm{KOH})$ à $10 \%$. Em ambos os testes as doze (12) linhagens foram identificadas como Gram positivas (Gram+). Na identificação morfológica foi usado o teste de coloração Gram, comprovando que as doze (12) linhagens de bactérias são Gram+ e em forma de bastonete curto.

As enzimas avaliadas neste estudo podem ser obtidas de animais, vegetais, bactérias, fungos e leveduras, com ampla aplicação nos diversos setores da indústria. As principais indústrias consumidoras de enzimas são: indústrias de detergente, processamento de amido, laticínios, cervejarias, sucos de frutas e vinhos, panificação, têxtil e papel, couro, entre outras indústrias (LIMA et al, 2001).

Para a determinação enzimática qualitativa a zona mais clara ao redor do "cup plate" corresponde ao halo indicador de degradação enzimática, através do qual foi possível estabelecer o índice enzimático (I.E.), demonstrando a capacidade dos isolados bacterianos em degradar os substratos de acordo com a enzima analisada (xilano de birchwood para xilanases, amido para amilases, gelatina para proteases e carboximetilcelulose para celulases e pectina para pectinases), como foi descrito anteriormente e estão ilustrados na figura 1.

Figura 1. Perfil enzimático dos isolados bacterianas isolados de Biodigestor constituído de RSU.

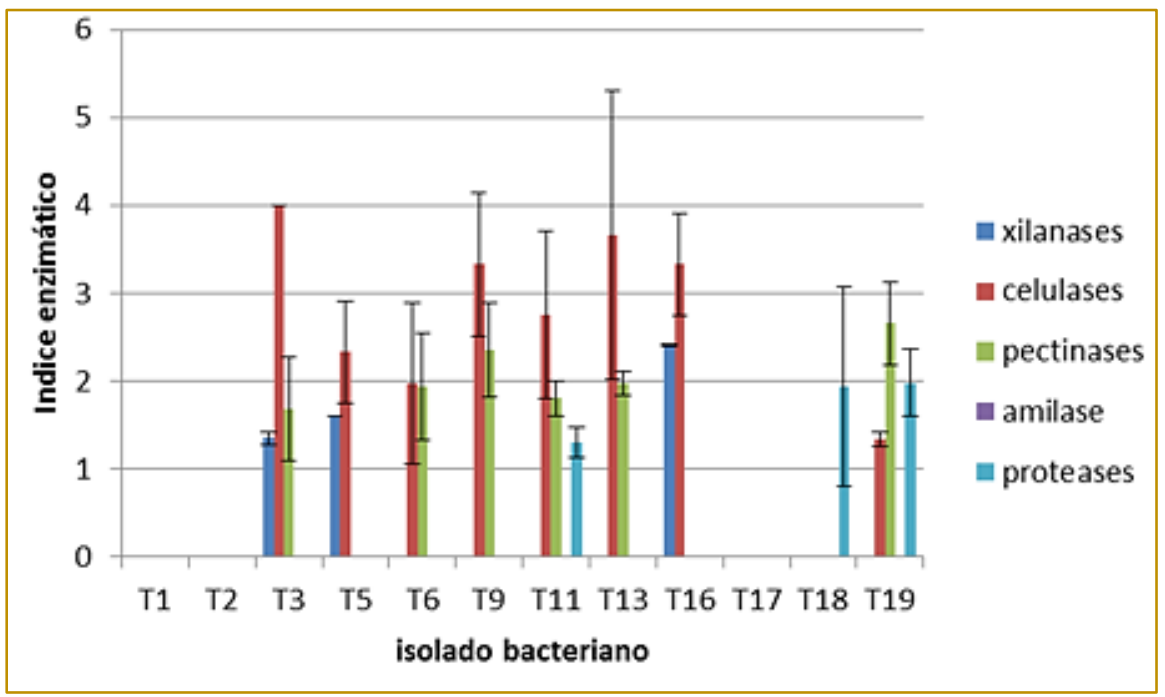

Das dozes linhagens bacterianas apenas três foram capazes de degradar o xilano, a T16 se destacou seguida da T5 e T3. Os isolados bactérianos T3, T6, T9, T11, T13 e T19 mostraram capazes de degradar a pectina. As linhagens bacterianas T11, T18 e T19 
foram capazes de excretar proteases. Os isolados T3, T5, T6, T9, T11, T13, T16 e T19 são capazes de degradar 0 carboximetilcelulose. Neste estudo detectouse que das doze linhagens isoladas do biodigestor constituído de resíduo sólido urbano, nenhuma foi capaz de degradar o amido. Estes dados estão presentes na tabela 1.

Tabela 1. Atividades enzimáticas qualitativas, halos de degradação (mm).

\begin{tabular}{|c|c|c|c|c|c|}
\hline $\begin{array}{l}\text { Isolados } \\
\text { bacterianos }\end{array}$ & Xilanases & Celulases & Pectinases & Amilase & Proteases \\
\hline $\mathrm{T} 1$ & 0 & 0 & 0 & 0 & 0 \\
\hline T2 & 0 & 0 & 0 & 0 & 0 \\
\hline T3 & 1,35 & 4 & 1,68 & 0 & 0 \\
\hline T5 & 1,6 & 2,33 & 0 & 0 & 0 \\
\hline T6 & 0 & 1,97 & 1,94 & 0 & 0 \\
\hline T9 & 0 & 3,33 & 2,35 & 0 & 0 \\
\hline $\mathrm{T} 11$ & 0 & 2,75 & 1,8 & 0 & 1,3 \\
\hline T13 & 0 & 3,66 & 1,97 & 0 & 0 \\
\hline T16 & 2,41 & 3,33 & 0 & 0 & 0 \\
\hline T17 & 0 & 0 & 0 & 0 & 0 \\
\hline T18 & 0 & 0 & 0 & 0 & 1,94 \\
\hline T19 & 0 & 1,33 & 2,66 & 0 & 1,98 \\
\hline
\end{tabular}

\section{CONCLUSÃO}

Dentre as doze linhagens bactérias analisadas nenhuma foi capaz de excretar todas as cinco enzimas avaliadas. Neste contexto se destacaram principalmente dois isolados a T16 com índices enzimáticos superiores a 2,4 na degradação de xilano e celulose e o isolado T19 também se destacou quanto a capacidade de produzir pectinase e proteases. A amilase não foi produzida por nenhum isolado estudado.

A criação de um provável consórcio com essas duas bactérias que apresentaram melhores resultados.

\section{REFERENNCIAS}

[1] Amaral, Fernando Luciano Merlido. Biodigestão Anaeróbia dos Resíduos Sólidos Urbanos. Um panorama tecnológico atual. Dissertação de Mestrado. São Paulo, 2004. 107p.

[2] Atlas Brasileiro de Emissões de GEE e Potencial Energético na Destinação de Resíduos Sólido. ABRELPE.

[3] Blogbgs. Histórico do biogás. Publicado 08/02/2013. Acesso em: 11 mar. 2015. Online. Disponível em:

$<$ http://bgsequipamentos.com.br/blog/helloworld/>.

[4] Galeffi, Carlo. Biogás no mundo. Acesso em 11 mar. 2015. Online. Disponível em: < http://www.portalresiduossolidos.com/biogas-nomundo-carlo-galeffi/>

\section{AGRADECIMENTOS}

Ao IFPE e CNPq pela concessão da bolsa de Iniciação Científica. Ao Grupo de Pesquisa BIOGÁS - Desenvolvimento de Soluções Tecnológicas a partir do Biogás Produzido em Sistema de Tratamento e Aterros Sanitários para Geração de EE do Centro de Tecnologia e Geociências (CTG) da UFPE pela parceria e disponibilidade de infraestrutura. Ao Laboratório de Microbiologia Ambiental e Industrial (LAMAI) da UFPE pela parceria e disponibilidade de infraestrutura e material.

[5] Kaltschmitt et al, 2001. Fundamentos da Fermentação Anaeróbia. In: Guia Prático do Biogás - Geração e Utilização. 50 edição. Gülzow. 2010.Cap. 2, p. 20-21

[6] Hankin, L.; Anagnostakis, S. L. The use of solid media for detection of enzymes production by fungi. Mycologia, v. 67, n. 3, p. 597-607, 1975.

[7] Instituto Brasileiro de Defesa do Consumidor-IDEC. Vitória do consumidor: adiamento do encerramento de lixões é vetado. Acesso em 10 mar. 2015. Online. Disponível em: $<$ http://www.idec.org.br/em-acao/em-foco/vitoriado-consumidor-adiamento-de-encerramento-delixes-e-vetado>.

[8] Lima, U. A.; Aguarone, E.; Borzani, W.; Schmidell,W. Biotecnologia Industrial. Editora Edgard Blucher Ltda, 2001. 
[9] Mata, A. J. 2002. Fundamentals of the anaerobic digestion proches, in Biomethanization of the organic fraction of municipal solid wastes, Mata Alvarez er. IWA publishing ISBN 19900222140, pp 1-20.

[10] Relatório final do IPCC não deixa dúvidas: precisamos agir agora. Acesso em 10 mar. 2015.
Online. Disponível em: $<$ http://www.greenpeace.org/brasil/pt/Noticias/Relat orio-final-do-IPCC-nao-deixa-duvidas-precisamosagir-agora/>.

[11] Ventura, Manuel M. Enzimas em Biotecnologia - Produção, Aplicação e Mercado. Editora Interciência Ltda, Rio de Janeiro,1999. 


\section{Capítulo 15}

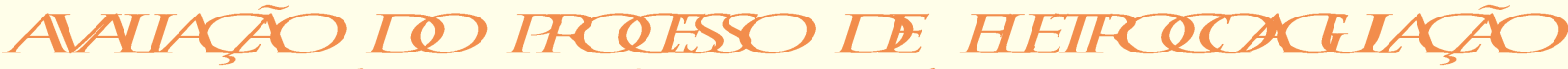

 AHCDICS}

\section{André Aguiar Battistelli}

Maria Eliza Nagel Hassemer

Naiara Mottim Justino

Flávio Rubens Lapolli

Resumo - O aporte excessivo de fósforo, decorrente do despejo de efluentes sanitários, tem sido considerado um dos maiores problemas relacionados à constante degradação dos corpos hídricos, dessa forma, a remoção desse nutriente deve ser considerada nos sistemas de tratamento propostos. Nesse contexto, esse trabalho buscou avaliar o processo de eletrocoagulação com a aplicação de correntes elétricas de baixa intensidade, objetivando a remoção de fósforo em reatores aeróbios. Um planejamento fatorial $2^{2}$ foi previamente elaborado para realização de experimentos em escala de bancada, onde foram avaliados diferentes gradientes de tensão (1,0; 1,5 e 2,0 V) e modos de exposição à corrente elétrica (6 ON/6 OFF; 6 ON/12 OFF; 6 ON/18 OFF - minutos) aplicados em lodos aeróbios sob constante aeração, durante 70h. O sistema empregado mostrou-se altamente eficiente, tendo alcançado, na melhor condição operacional, remoção média de 99,95\% de $\mathrm{P}_{-} \mathrm{PO}_{4}{ }^{3}$, demonstrando, assim, elevado potencial de utilização nas estações de tratamento de efluentes objetivando a minimização dos impactos ambientais decorrentes desse nutriente.

Palavras-chave: Eutrofização; reatores aeróbios; eletrocoagulação; remoção de fósforo. 


\section{INTRODUÇÃO}

A disposição inadequada de efluentes sanitários não tratados ou submetidos a um tratamento insatisfatório tem sido considerada um dos maiores problemas relacionados à degradação dos corpos hídricos, principalmente no que tange ao fenômeno da eutrofização, resultante do aporte excessivo de nutrientes, sobretudo o fósforo. Nesse contexto, é evidente a necessidade da remoção desse nutriente nas estações de tratamento de esgotos existentes.

De acordo com Irdemez, Yildiz e Tosunoğlu (2006), o fósforo é usualmente encontrado em efluentes sanitários, sobretudo, sob a forma de ortofosfato solúvel $\left(\mathrm{P}-\mathrm{PO}_{4}{ }^{3-}\right)$, cuja remoção é usualmente realizada através de processos físico-químicos ou biológicos (LACASA et al., 2011). O processo biológico, conhecido como Enhanced Biological Phosphorus Removal, é baseado na intermitência entre fases aeróbias e anaeróbias que permitem aos microrganismos acumular uma quantidade de fósforo maior que a necessária a seu metabolismo, removendo assim esse nutriente do meio (METCALF e EDDY, 2003). Entretanto, apesar de oferecer vantagens como baixo custo de operação e menor produção de lodo, esse método nem sempre permite atingir eficiências de tratamento satisfatórias (KIM, DENG e BENJAMIN, 2008). O processo de coagulação química e posterior precipitação do fósforo é considerado, por sua vez, um método bastante eficaz para a remoção desse nutriente dos efluentes sanitários (MORSE et al., 1998; SHALABY et al., 2014) Todavia, sua aplicação tem sido limitada devido à grande quantidade de produtos químicos necessários, ao incremento significativo na produção de lodo nos sistemas e a possibilidade de contaminação dos corpos receptores, devido à concentração residual dos compostos utilizados (CLARK e STEPHENSON, 1998; TRAN et al., 2012)

Desse modo, a aplicação do processo de eletrocoagulação (EC), aparece como uma alternativa interessante, pois, ao contrário dos processos de coagulação tradicionais, não utilizam produtos químicos e consequentemente, não apresentam os efeitos negativos supracitados (ZHU; CLIFFORD e CHELLAM, 2005). A EC consiste na aplicação de uma corrente elétrica de corrente contínua (CC) entre dois eletrodos submersos, causando a eletrólise de sua superfície e a oxidação do ânodo metálico (M) para o seu catíon $\left(\mathrm{Mn}^{+}\right)$, liberando íons metálicos em solução, que promovem a precipitação do fosfato insolúvel e permitem, assim, a sua remoção por meio de processos de separação de fases, como precipitação, flotação ou filtração em membranas (MOLLAH et al., 2001; CHEN, 2004). Outra vantagem significativa da EC é a possibilidade de aplicação associada a processos biológicos em um reator de câmara única, excluindo, dessa forma, a necessidade de uma unidade adicional para remoção do fósforo (ALSHAWABKEH, SHEN e MAILLACHERUVU, 2004). Porém, nesse caso, devido ao possível efeito adverso que a eletricidade pode exercer sobre a biomassa, é recomendável a aplicação de correntes de baixa intensidade e modos de exposição intermitentes no sistema (BANI-MELHEM et al., 2011).

Perante o que foi exposto, o objetivo deste trabalho foi avaliar o processo de eletrocoagulação aplicado à remoção de fósforo em reatores aeróbios em escala de bancada utilizando correntes de baixa intensidade, buscando, dessa forma, soluções eficazes que permitam melhorias no tratamento de efluentes domésticos através de tecnologias inovadoras.

\section{MATERIAL E MÉTODOS \\ 2.1 UNIDADE EXPERIMENTAL}

A unidade experimental utilizada no trabalho, composta por cinco eletro-biorreatores em escala de bancada está exemplificada na Figura 1 
Figura 1 - Unidade experimental em escala de bancada. 1) Fonte de alimentação ajustável; 2) Painel de controle; 3) Sistema de aeração; 4) Eletro-Biorreatores.

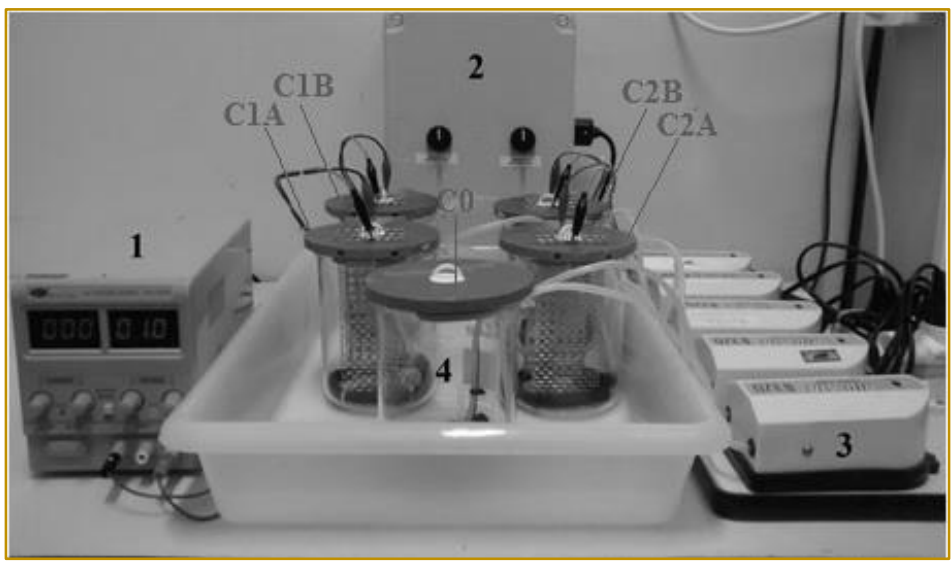

Fonte: Própria

O sistema era composto dois circuitos independentes $\left(\mathrm{C}_{1}\right.$ e $\left.\mathrm{C}_{2}\right)$, com dois eletrobiorreatores ligados em cada ( $\mathrm{A}$ e $\mathrm{B}$ ), permitindo assim, a operação simultânea de duas condições operacionais distintas. O quinto biorreator $\left(\mathrm{C}_{0}\right)$ possuía as mesmas configurações dos demais, porém não era conectado ao sistema elétrico, de modo a permitir a operação sem aplicação de corrente. Cada eletro-biorreator possuía 1,0 L de volume total e era equipado com eletrodos construídos em placas planas de alumínio (Ânodo) e de aço inoxidável (Cátodo), espaçados entre si por $5,0 \mathrm{~cm}$, com dimensões de $5,5 \times 14,0 \mathrm{~cm}$ e perfuração de $45 \%$ da área a fim de permitir um regime de mistura adequado do lodo. O provimento de oxigênio aos microrganismos, bem como a manutenção do regime de mistura completa era realizada através de difusores de ar instalados na base dos reatores. A densidade de corrente aplicada era controlada através de uma fonte de alimentação digital ajustável de corrente contínua (PS A305D), com variação de tensão de 0-30 V e de corrente de 0-5 A, já o tempo de exposição era regulado por temporizadores digitais instalados em um painel de controle entre a fonte de alimentação e os eletrodos.

\subsection{PROCEDIMENTO EXPERIMENTAL}

O lodo utilizado nos experimentos foi proveniente do tanque de aeração da estação de tratamento de esgotos (ETE) Insular da cidade de Florianópolis - SC, do tipo lodos ativados de aeração prolongada, pertencente à Companhia Catarinense de Águas e Esgotos (CASAN). As amostras eram coletadas anteriormente a cada ensaio e submetidas à sedimentação e retirada do sobrenadante visando estabilizar a concentração de sólidos para $5000 \mathrm{mg} \cdot \mathrm{L}^{-1}$. A concentração de $\mathrm{P}_{-} \mathrm{PO}_{4}{ }^{-3}$ inicial também era ajustada para valores próximos a 10,0 mg. $\mathrm{L}^{-1}$, por meio da adição de fosfato de potássio monobásico $\left(\mathrm{KH}_{2} \mathrm{PO}_{4}\right)$ a fim de propiciar uma padronização entre as diferentes amostras. Em seguida, $800 \mathrm{~mL}$ de lodo padrozinado eram inoculados em cada reator e iniciado o processo de eletroagulação em regime de mistura completa sob aeração constante e temperatura ambiente controlada em $24^{\circ} \mathrm{C}$. Durante os experimentos, foram testados três gradientes de tensão $(1,0,1,5$ e 2,0 V), que forneceram diferentes densidades de corrente entre os eletrodos, além de três modos de exposição diferentes, em minutos (6 ON/6 OFF; 6 ON/12 OFF; 6 ON/18 OFF).

A fim de avaliar o efeito de cada variável (gradiente de tensão e modos de exposição) no processo, bem como a correlação entre tais variáveis, e assim, determinar as melhores condições operacionais com um número mínimo de ensaios, foi realizado um planejamento fatorial $2^{2}$ com ponto central (em triplicata), apresentado na Tabela 1. Os valores dos níveis para as variáveis foram adotados com base no estudo prévio de Ibeid, Elektorowicz e Oleszkiewicz (2013). 
Tabela 1 - Planejamento fatorial $2^{2}$, com ponto central em triplicata, elaborado para a determinação das melhores condições operacionais elétricas do sistema, objetivando a remoção de $\mathrm{PO}_{4}^{-3}$.

\begin{tabular}{|c|c|c|c|}
\hline & Nivel $(-)$ & Nível $(0)$ & Nivel $(+)$ \\
\hline 1. Gradiente de Tensão (V) & 1,0 & 1,5 & 2,0 \\
\hline 2. Modos de exposição (Min) & 6 ON/18 OFF & 6 ON/12 OFF & 6 ON/6 OFF \\
\hline & \multicolumn{3}{|c|}{ Variáveis } \\
\hline Ensaio & 1 & 2 & $+1 \times 2$ \\
\hline 1 & - & - & - \\
\hline 2 & + & + & - \\
\hline 3 & - & + & + \\
\hline 4 & + & 0 & 0 \\
\hline 5 & 0 & 0 & 0 \\
\hline 6 & 0 & 0 & 0 \\
\hline
\end{tabular}

Cada condição foi avaliada em duplicata durante $70 \mathrm{~h}$ e um biorreator sem aplicação de corrente elétrica foi operado simultaneamente para fins de comparação.

\subsection{MÉTODOS ANALÍTICOS}

Os parâmetros $\mathrm{pH}$, condutividade e densidade de corrente foram monitorados continuamente de acordo com os métodos descritos na Tabela 2.

Tabela 2 - Parâmetros avaliado ao longo da operação do reatores e os respectivos métodos de análise utilizados.

\begin{tabular}{|c|c|}
\hline Parâmetro & Método de análise \\
\hline Condutividade & Condutivímetro Portátil (Hanna HI-991300) \\
\hline $\mathrm{pH}$ & Método potenciométrico e leitura em pHmetro (Qualxtron QX-110) \\
\hline Densidade de Corrente $^{1}$ & Multímetro Digital (Power DT-830B) \\
\hline
\end{tabular}

A concentração de ortofosfato solúvel $\left(\mathrm{P}_{-} \mathrm{PO}_{4}{ }^{-}\right.$ ${ }^{3}$ ) foi quantificada na amostra de lodo antes e após a aplicação do processo de eletrocoagulação, permitindo, dessa forma, avaliar o percentual de remoção alcançado. Para realização do procedimento, as amostras eram previamente filtradas em membrana de acetato celulose com tamanho de poro de 0,45 um. O método utilizado, descrito no Standard Methods for Examination of the Water and Wastewater (APHA, 1998), consiste na reação do $\mathrm{P}_{-} \mathrm{PO}_{4}^{-3} \mathrm{com}$ molibdato em meio ácido, produzindo um complexo misto molibdato/ortofosfato que, na presença do íon vanadato, forma o ácido molibdovanadofosfórico, de cor amarelada. A intensidade da cor amarela é proporcional à concentração de ortofosfato na amostra. As leituras eram realizadas em espectrofotômetro $\mathrm{HACH}$ DR5000 sob o comprimento de onda de $420 \mathrm{~nm}$.

\section{RESULTADOS E DISCUSSÃO \\ 3.1 MONITORAMENTO DOS REATORES}

$\mathrm{Na}$ Tabela 3 são apresentados os dados referentes ao monitoramento contínuo dos reatores durante 0 processo de eletrocoagulação quanto a densidade de corrente, $\mathrm{pH}$ e condutividade. 
Tabela 3 - Resultados obtidos referentes ao monitoramento do $\mathrm{pH}$, condutividade e densidade de corrente aplicada, para cada ensaio realizado.

\begin{tabular}{|c|c|c|c|c|c|c|c|}
\hline \multirow[b]{2}{*}{ Ensaio } & \multirow{2}{*}{$\begin{array}{l}\text { Grad. } \\
\text { de } \\
\text { Tensão } \\
\text { (V) }\end{array}$} & \multirow{2}{*}{$\begin{array}{l}\text { Modo de Exp. } \\
\quad \text { (Min) }\end{array}$} & \multirow{2}{*}{$\begin{array}{l}\text { Densidad } \\
\text { e Corrente } \\
\left(A \cdot m^{-2}\right)\end{array}$} & \multicolumn{2}{|c|}{$\mathrm{PH}$} & \multicolumn{2}{|c|}{ Condutividade $\left(\mu \mathrm{S} . \mathrm{cm}^{-1}\right)$} \\
\hline & & & & CO & $\mathrm{C} 1$ e C2 & $\mathrm{CO}$ & 2 \\
\hline 1 & 1,0 & 6 ON/18 OFF & 5,1 & $7,25 \pm 0,40$ & $7,40 \pm 0,42$ & $976,6 \pm 24,7$ & $956,4 \pm 39,15$ \\
\hline 2 & 2,0 & $6 \mathrm{ON} / 18 \mathrm{OFF}$ & 9,5 & $6,59 \pm 0,42$ & $6,98 \pm 0,23$ & $950,89 \pm 90,2$ & $921,40 \pm 67,93$ \\
\hline 3 & 1,0 & 6 ON/6 OFF & 5,1 & $7,25 \pm 0,40$ & $7,65 \pm 0,39$ & $976,6 \pm 24,7$ & $945,5 \pm 62,15$ \\
\hline 4 & 2,0 & 6 ON/6 OFF & 9,5 & $6,59 \pm 0,42$ & $7,02 \pm 0,19$ & $950,89 \pm 90,2$ & $897,70 \pm 44,92$ \\
\hline 5,6 e 7 & 1,5 & 6 ON/12 OFF & 6,5 & $6,25 \pm 0,55$ & $6,94 \pm 0,27$ & $702,0 \pm 123,3$ & $685,60 \pm 53,9$ \\
\hline
\end{tabular}

Na Tabela 3 é possível verificar que após a realização dos ensaios, os valores de $\mathrm{pH}$ do lodo avaliado apresentaram um pequeno acréscimo, proporcional à densidade de corrente aplicada e ao modo de exposição, em relação ao lodo inoculado no reator controle. Ibeid, Elektorowicz e Oleszkiewicz (2013), em estudo sobre a influência da aplicação de correntes elétricas de baixa tensão em lodos ativados, também observaram comportamento semelhante. De acordo com Apaydin, Kurt e Gönüllü, (2009), esse comportamento pode ser atribuído à liberação de radicais hidroxila $\left(\mathrm{OH}^{-}\right)$para o meio, de acordo com a seguinte equação: $\left(4 \mathrm{H}_{2} \mathrm{O}+4 \mathrm{e}^{-} \rightarrow 2 \mathrm{H}_{2 \text { (gas) }}+4 \mathrm{OH}_{(\text {aq) }}^{-}\right)$. Entretanto, o aumento de $\mathrm{pH}$ observado não causaria grandes prejuízos à biomassa do reator, e, portanto, não afetaria significativamente 0 desempenho do tratamento biológico. Já em relação à condutividade, uma pequena diminuição pode ser observada, quando comparados os reatores controle, com os reatores submetidos à corrente elétrica, o que pode ser explicado pela redução dos compostos solúveis no meio, em função do processo de eletrocoagulação. Porém, em escala real, sob regime de fluxo contínuo, esse fenômeno seria minimizado pela constante adição de sais provenientes do esgoto afluente.

\subsection{REMOÇÃO DE FÓSFORO}

Na Tabela 4 são apresentados os resultados referentes ao percentual de remoção de fósforo, para cada condição testada, de acordo com o planejamento fatorial $2^{2}$ previamente realizado.

Tabela 4 - Planejamento fatorial $2^{2}$ elaborado para realização dos ensaios, apresentando como resposta o percentual de remoção de $\mathrm{P}_{-} \mathrm{PO}_{4}{ }^{3-}$

\begin{tabular}{|c|c|c|c|c|c|c|}
\hline \multirow{2}{*}{\multicolumn{4}{|c|}{ Variável }} & \multicolumn{3}{|c|}{ Nível } \\
\hline & & & & - & 0 & + \\
\hline \multicolumn{4}{|c|}{ 1. Gradiente de Tensão (V) } & 1,00 & 1,50 & 2,00 \\
\hline \multicolumn{4}{|c|}{ 2. Modo de Exp. (Min) } & $6 \mathrm{ON} / 18 \mathrm{OFF}$ & $6 \mathrm{ON} / 12 \mathrm{OFF}$ & $6 \mathrm{ON} / 6 \mathrm{OFF}$ \\
\hline \multirow{2}{*}{ Ensaio } & \multicolumn{3}{|c|}{ Variáveis } & \multirow{2}{*}{\multicolumn{3}{|c|}{ Remoção de $\mathrm{P}_{-} \mathrm{PO}_{4}{ }^{3-}(\%)$}} \\
\hline & 1 & 2 & $1 \times 2$ & & & \\
\hline 1 & - & - & + & \multicolumn{3}{|c|}{89,91} \\
\hline 2 & + & - & - & \multicolumn{3}{|c|}{98,90} \\
\hline 3 & - & + & - & \multicolumn{3}{|c|}{98,06} \\
\hline 4 & + & + & + & \multicolumn{3}{|c|}{99,95} \\
\hline 5 & 0 & 0 & 0 & \multicolumn{3}{|c|}{99,76} \\
\hline 6 & 0 & 0 & 0 & \multicolumn{3}{|c|}{98,88} \\
\hline 7 & 0 & 0 & 0 & \multicolumn{3}{|c|}{98,72} \\
\hline
\end{tabular}

Efeitos principais - Gradiente de Tensão: + 5,44 \pm 0,55; Modo de Exposição: + 4,59 \pm 0,55. Efeito combinado - Gradiente de Tensão x Modo de Exposição: - 3,54 $\pm 0,55$. 
Ao realizar um planejamento fatorial, é necessário identificar a influência que o aumento de cada variável apresenta sobre a resposta, assim como a interação entre elas. Para este fim, foram calculados os efeitos principais (de cada variável isolada) e de interação entre as variáveis. Os resultados apresentados no rodapé da Tabela 4 mostram que todos os fatores possuem influência significativa, tanto isolados quanto combinados, em função de seus valores numéricos serem superiores ao desvio padrão (0,55\%), calculado a partir do ensaio em triplicata do ponto central. Para melhor visualização, na Figura 2 é apresentada a representação geométrica dos resultados obtidos.

Figura 2 - Representação geométrica dos resultados obtidos para remoção de $\mathrm{P}-\mathrm{PO}_{4}{ }^{3-} \mathrm{em}$ cada condição avaliada.

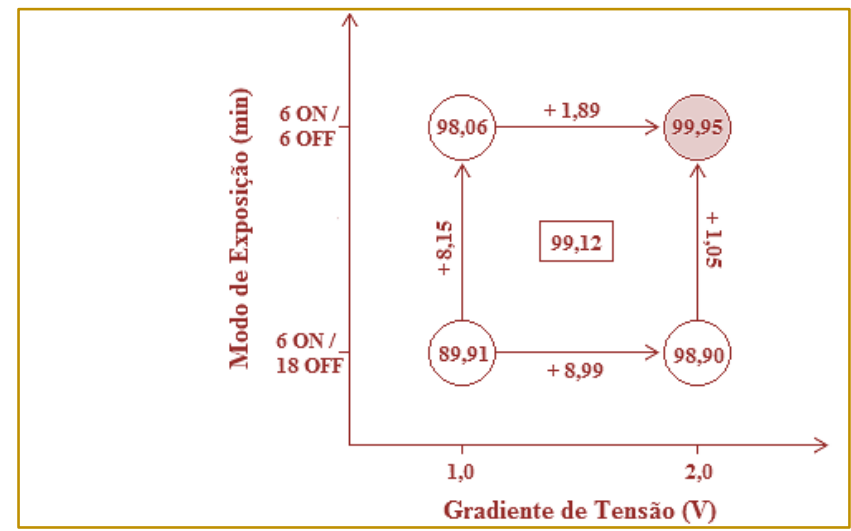

De acordo com os dados apresentados na Figura 2, é possível constatar que o aumento no gradiente de tensão de 1,0 para $2,0 \mathrm{~V}$, resultou na melhoria de rendimento do processo, especialmente sob o modo de exposição de 6 ON / 18 OFF, onde o acréscimo observado foi de 8,99\%. Da mesma forma, a alteração de nível no modo de exposição (6 ON / 18 OFF para 6 ON / 6 OFF) também proporcionou melhoria na eficiência de remoção, chegando ao aumento de $8,15 \%$ quando aplicado um gradiente de tensão de 1,0 V. Desse modo, a condição operacional em que foram aplicados 0 gradiente de tensão de $2,0 \mathrm{~V}$ e o modo de exposição de 6 ON / 6 OFF, mostrou-se mais eficiente, tendo apresentado remoção de fósforo solúvel $\left(\mathrm{P}_{-} \mathrm{PO}_{4}{ }^{-3}\right)$ de $99,95 \% \mathrm{com}$ concentração residual inferior à $0,01 \mathrm{mg} / \mathrm{L}$.

Os resultados obtidos na presente pesquisa são superiores aos observados por Kim et al. (2010), que utilizaram uma unidade de eletrocoagulação com eletrodos de alumínio e aplicação de gradiente de tensão de 1,70 V para o tratamento de efluentes domésticos, tendo alcançando remoção média de $\mathrm{P}_{-} \mathrm{PO}_{4}{ }^{3-}$ próxima a 90\%, com concentração residual de 0,3 mg/L. Hasan et al. (2014), por sua vez, utilizando um sistema de eletrocoagulação associado ao processo de filtração com membranas, obtiveram remoção de $\mathrm{P}_{-} \mathrm{PO}_{4}{ }^{3-}$ de 99,9\% aplicando uma densidade de corrente de 12 A.m - $^{-2}$ sob modo de exposição de 5 ON 110 OFF (min). Resultados semelhantes foram obtidos por Irdemez, Yildiz e Tosunoğlu (2006), que em estudo para a otimização do processo de eletrocoagulação em esgotos sanitários, aplicando uma densidade de corrente de 10 A.m ${ }^{-2}$ obtiveram remoções de $\mathrm{P}_{-} \mathrm{PO}_{4}{ }^{3-}$ superiores a 99,9\%.

\section{CONCLUSÕES}

O lodo inoculado nos reatores apresentou um pequeno acréscimo no $\mathrm{pH}$, bem como uma redução na condutividade em função da aplicação da corrente elétrica, entretanto, esse comportamento não comprometeu a aplicação do processo. A partir do planejamento fatorial previamente realizado para execução dos ensaios, foi possível determinar a melhor condição operacional para a remoção de fósforo $\left(\mathrm{P}-\mathrm{PO}_{4}{ }^{3-}\right)$, em termos de gradiente de tensão e modos de exposição à corrente elétrica, de 2,0 V e 6 ON / 6 OFF (min) respectivamente, condição em que foi atingida uma concentração residual de 0,01 mg. $\mathrm{L}^{-1}$, que correspondeu à 99,95 \% de remoção. Levando-se em consideração esses aspectos, conclui-se que o processo de 
tratamento proposto apresenta elevada potencialidade de aplicação em unidades de tratamento de efluentes domésticos, possibilitando a geração de um efluente final praticamente livre de fósforo.

\section{REFERÊNCIAS}

[1] Alshawabkeh, A. N.; Shen, Y.; Maillacheruvu, K. Y. Effect of DC electric fields on COD in aerobic mixed sludge processes. Environmental engineering science, $v$. 21, n. 3, p. 321-329, 2004.

[2] APHA (1998). Standard Methods For The Examination Of Water And Wastewater, 19 ed., Washington.

[3] Bani-Melhem, K.; Elektorowicz, M. Performance of the submerged membrane electrobioreactor (SMEBR) with iron electrodes for wastewater treatment and fouling reduction. Journal of Membrane Science, v. 379, n. 1, p. 434-439, 2011.

[4] Chen, G. Electrochemical technologies in wastewater treatment.Separation and purification Technology, v. 38, n. 1, p. 11-41, 2004.

[5] Clark, T.; Stephenson, T. Effects of chemical addition on aerobic biological treatment of municipal wastewater. Environmental technology, v. 19, n. 6, p. 579-590, 1998.

[6] Hasan, S. W.; Elektorowicz, M.; Oleszkiewicz, J. A. Start-up period investigation of pilot-scale submerged membrane electrobioreactor (SMEBR) treating raw municipal wastewater. Chemosphere, v. 97, p. 71-77, 2014.

[7] Ibeid, S.; Elektorowicz, M.; Oleszkiewicz, J. A. Modification of activated sludge properties caused by application of continuous and intermittent current. Water research, v. 47, n. 2, p. 903-910, 2013.

[8] Irdemez, Ş.; Yildiz, Y. Ş.; Tosunoğlu, V. Optimization of phosphate removal from wastewater by electrocoagulation with aluminum plate electrodes. Separation and purification Technology, v. 52, n. 2, p. 394-401, 2006.

[9] Kim, H. G.; Jang, H. N.; KIM, H. M.; Lee, D. S.; Chung, T. H. Effect of an electro phosphorous removal process on phosphorous removal and

\section{AGRADECIMENTO}

À fundação CAPES pela concessão de bolsa durante a realização da pesquisa.

membrane permeability in a pilot-scale MBR. Desalination, v. 250, n. 2, p. 629-633, 2010.

[10] KIM, J.; Deng, Q.; Benjamin, M. M. Simultaneous removal of phosphorus and foulants in a hybrid coagulation/membrane filtration system. Water research, v. 42, n. 8, p. 2017-2024, 2008.

[11] Lacasa, E.; Cañizares, P.; Saez, C.; Fernández, F. J.; Rodrigo, M. A. Electrochemical phosphates removal using iron and aluminium electrodes. Chemical Engineering Journal, v. 172, n. 1, p. 137-143, 2011.

[12] Metcalf; Eddy. Wastewater Engineering Treatment and reuse. 4. ed. Boston: McGraw-Hill, 2003.

[13] Mollah, M. Y.; Schennach, R.; Parga, J. R.; Cocke, D. L. Electrocoagulation (EC)—science and applications. Journal of hazardous materials, v. 84, n. 1, p. 29-41, 2001

[14] Morse, G. K.; Brett, S. W.; Guy, J. A.; Lester, J. N. Review: phosphorus removal and recovery technologies. Science of the total environment, v. 212, n. 1, p. 69-81, 1998.

[15] Shalaby, A.; Nassef, E.; Mubark, A.; Hussein, M. Phosphate removal from wastewater by electrocoagulation using aluminium electrodes. American Journal of Environmental Engineering and Science, v. 5, n.1, p. 90-98, 2014.

[16] Tran, N.; Drogui, P.; Blais, J. F.; Mercier, G. Phosphorus removal from spiked municipal wastewater using either electrochemical coagulation or chemical coagulation as tertiary treatment. Separation and Purification Technology, v. 95, p. 16-25, 2012.

[17] Zhu, B; Clifford, D. A.; Chellam, S. Comparison of electrocoagulation and chemical coagulation pretreatment for enhanced virus removal using microfiltration membranes. Water Research, v. 39, n. 13, p. 3098-3108, 2005. 


\section{Gapítulo 16}

\section{AVANCOS E RETROCESSOS DA ATUALIZACÃO DA INSTRUCÃO NORMATIVA SOBRE O GERENCIAMENTO DE RESIDUUOS SÓLIDOS DE SAÚDE COM FOCO NOS RESIDUOS MEDICAMENTOSOS}

\section{Renata Oliveira Luís}

Hygor Aristides Victor Rossoni

Resumo: O presente trabalho possui o objetivo de realizar a análise de conteúdo temático-categorial entre a normativa da Agência Nacional de Vigilância Sanitária n.- 306/2005 e sua atualização RDC n.ำ 222/2018, com foco nos resíduos de medicamentos, considerando os impactos ambientais e a aplicação em estabelecimentos farmacêuticos. Contatou-se que apesar da revisão buscar se adequar as principais inovações tecnológicas, careceu de posicionamento claro quanto ao descarte de resíduos medicamentosos, não privilegiando iniciativas de logística reversa ou o reaproveitamento energético.

Palavras chave: medicamentos; logística reversa; reaproveitamento energético; PGRSS. 


\section{INTRODUÇÃO}

A Política Nacional de Resíduos Sólidos, por meio da Lei n.- 12.305/2010, introduziu novos conceitos e entendimentos com base na evolução das tecnologias relacionadas aos resíduos sólidos de saúde (RSS). Dessa forma, a Resolução da Diretoria Colegiada (RDC) da ANVISA n. 306/2004, que versava sobre o gerenciamento dos RSS apresentava falhas quanto ao manejo e tratamento desses resíduos, necessitando de atualização.

Após uma janela de 11 anos, em julho de 2015, por meio da consulta pública n.ำ 20, foram propostas contribuições à ANVISA para a revisão da RDC n.ㅇ 306/2004. Em 2018, finda-se esse processo e então é publicada a RDC n.․․ 222.

Esse artigo objetiva comparar as modificações entre as RDC n. 306/2005 e 222/2018 com foco nos resíduos de medicamentos, explanar sobre os impactos relacionados aos aspectos ambientais e a aplicação prática da normativa em estabelecimentos farmacêuticos.

\section{METODOLOGIA}

Foi utilizado o método da Análise de Conteúdo Temático-Categorial, que, conforme Bardin (2011) consiste em descobrir os núcleos de sentido que compõem uma comunicação cuja presença ou frequência tenham algum significado para o objetivo analítico visado.

Após a formulação dos objetivos, a análise foi dividida em três etapas, conforme preconizado por Oliveira, 2008: i) pré-análise: definição do corpus por meio da leitura flutuante; formulação das categorias; ii) exploração do material: agregação dos dados brutos em características pertinentes ao conteúdo expresso nos sítios eletrônicos; e iii) tratamento dos resultados, inferência e interpretação: análise qualitativa comparativa dos dados.

Tanto a RDC n.. 222/2018 quanto a RDC n.․․ 306/2005 foram acessadas no site da ANVISA. Assim, foi explorado o material e definido os itens e artigos novos que estavam relacionados aos resíduos medicamentosos.

Em seguida, utilizou-se a ferramenta de pesquisa do navegador para busca por expressões previamente definidas. Desse modo, as informações foram segregadas, avaliadas e realizadas as inferências e comparações necessárias à tratativa dos dados.

\section{RESULTADOS E DISCUSSÃO}

Inicialmente, a RDC revisada diferenciou-se quanto à abrangência, passando a ser aplicada aos geradores de serviços de RSS sejam eles públicos, filantrópicos, militares, instituição de ensino e pesquisa. Anteriormente, os estabelecimentos caracterizados como privados não eram obrigados a atender à normativa e somente em tempo recente passaram a se adequar às exigências da norma.

Em seguida, conforme descrito na tabela 1, pode-se identificar as principais atualizações propostas pela nova regulamentação sobre o gerenciamento dos resíduos sólidos de saúde, com base na técnica de Análise de Conteúdo Temático-categorial. 
Tabela 1 - Análise de Conteúdo Temático-Categorial comparativa entre as RDC n. 306/2004 e RDC n.. 222/2018 com foco nos resíduos medicamentosos.

\begin{tabular}{|c|c|c|}
\hline \multirow{2}{*}{ 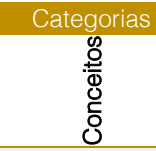 } & RDC n. $9306 / 2004$ & RDC n. $\div 222 / 2018$ \\
\hline & $\begin{array}{l}\text { Não refere a conceitos relacionados às tecnologias } \\
\text { atuais de gestão de resíduos sólidos }\end{array}$ & $\begin{array}{l}\text { Foram inseridos novos conceitos e/ou modificados, a fim de se } \\
\text { adequarem as atuais tecnologias, dentre eles: coletor, LR e resíduo } \\
\text { perigoso. }\end{array}$ \\
\hline $\begin{array}{l}m \\
\stackrel{m}{2} \\
\frac{0}{w} \\
\mathbb{d} \\
\simeq\end{array}$ & $\begin{array}{l}\text { Resíduos contendo substâncias químicas que } \\
\text { podem apresentar risco à saúde pública ou ao meio } \\
\text { ambiente, dependendo de suas características de } \\
\text { inflamabilidade, corrosividade, reatividade e } \\
\text { toxicidade. }\end{array}$ & $\begin{array}{l}\text { Incluiu as características carcinogenicidade, teratogenicidade, } \\
\text { mutagenicidade e quantidade aos resíduos B. }\end{array}$ \\
\hline \multirow{5}{*}{ 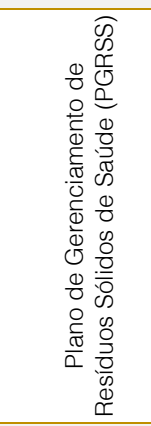 } & $\begin{array}{l}\text { Exigia se o desenvolvimento de instrumentos de } \\
\text { avaliação e controle para acompanhamento da } \\
\text { eficácia do PGRSS. }\end{array}$ & \multirow{2}{*}{$\begin{array}{l}\text { A nova legislação, não faz essas exigências, nem define outros } \\
\text { métodos substitutivos. }\end{array}$} \\
\hline & $\begin{array}{l}\text { Exigia-se o registro dos resultados do } \\
\text { monitoramento do tratamento dos RSS por sistema } \\
\text { próprio dos estabelecimentos de saúde. }\end{array}$ & \\
\hline & $\begin{array}{l}\text { Não refere ao armazenamento temporário, nem aos } \\
\text { procedimentos de LR. }\end{array}$ & $\begin{array}{l}\text { Inclui a definição das abordagens dos procedimentos para o } \\
\text { armazenamento temporário e para o processo de LR. }\end{array}$ \\
\hline & $\begin{array}{l}\text { Os resultados do monitoramento dos registros } \\
\text { devem ser registrados em documento próprio e } \\
\text { mantidos em local seguro durante cinco anos. }\end{array}$ & $\begin{array}{l}\text { Determinou o arquivamento dos registros de treinamento e documento } \\
\text { comprobatório de venda/doação dos RSS por } 5 \text { anos para fins de } \\
\text { avaliação de qualidade. }\end{array}$ \\
\hline & $\begin{array}{l}\text { Responsabilizava-se o profissional designado com } \\
\text { certificado de responsabilidade técnica para ser o } \\
\text { responsável pelo PGRSS. }\end{array}$ & O serviço gerador de RSS passa a ser o responsável pelo PGRSS. \\
\hline 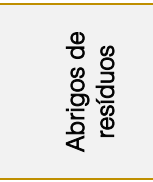 & $\begin{array}{l}\text { Os abrigos de resíduos deveriam ser fechados em } \\
\text { alvenaria e conectados à rede de esgoto. }\end{array}$ & $\begin{array}{l}\text { Os abrigos temporários e externos de resíduos deixam de ser } \\
\text { definidos como de alvenaria, e além de serem conectados à rede de } \\
\text { esgoto, precisarão ser instalados sistema elétrico e de combate a } \\
\text { incêndio, área coberta para pesagem dos RSS e caixa de retenção } \\
\text { nas canaletas para armazenamento de resíduos líquidos ou outra } \\
\text { forma de contenção validada. }\end{array}$ \\
\hline \multirow{2}{*}{  } & $\begin{array}{l}\text { Permitia-se a identificação dos resíduos com } \\
\text { adesivos }\end{array}$ & Foi vetado o uso de adesivos para a identificação do resíduo \\
\hline & $\begin{array}{l}\text { A coleta e os veículos atendiam as diretrizes da } \\
\text { Associação Brasileira de Normas Técnicas (ABNT) }\end{array}$ & $\begin{array}{l}\text { Veículo de transporte dos RSS deve ser exclusivo e passa a atender } \\
\text { as diretrizes dos Planos Municipais de RS. Além disso, eles não } \\
\text { poderão possuir sistema de compactação que danifique os sacos, } \\
\text { exceto para os resíduos do tipo D. }\end{array}$ \\
\hline 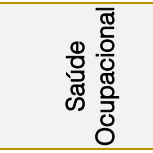 & $\begin{array}{l}\text { Era abordado temas relacionados à segurança do } \\
\text { trabalho, tais como: redução de ruídos, limite de } \\
\text { carga dos recipientes coletores e imunização dos } \\
\text { trabalhadores. }\end{array}$ & $\begin{array}{l}\text { Não será mais normatizado sobre esses assuntos nessa RDC. } \\
\text { Entretanto, ampliou-se os temas a serem trabalhados na capacitação } \\
\text { dos trabalhadores em gerenciamento dos RSS. }\end{array}$ \\
\hline \multicolumn{2}{|c|}{$\begin{array}{l}\text { Não deixava claro se o tratamento poderia ser realizado dentro ou fora } \\
\text { da unidade geradora. }\end{array}$} & \\
\hline \multicolumn{2}{|c|}{$\begin{array}{l}\text { Resíduos químicos que apresentam ou não riscos, poderiam ser } \\
\text { reutilizados, recuperados ou reciclados. }\end{array}$} & $\begin{array}{l}\text { RSS que não apresentem riscos químicos, biológicos ou radiológicos } \\
\text { podem ser encaminhados para recuperação, reciclagem, } \\
\text { compostagem, aproveitamento energético ou para LR, e } \\
\text { necessariamente devem ser dispostos de forma ambientalmente } \\
\text { adequada. }\end{array}$ \\
\hline \multicolumn{2}{|c|}{$\begin{array}{l}\text { Resíduos líquidos podem ser lançados em corpos receptores, sem } \\
\text { tratamento. }\end{array}$} & $\begin{array}{l}\text { Resíduos líquidos devem ser submetidos a tratamento antes da } \\
\text { destinação final. }\end{array}$ \\
\hline \multicolumn{2}{|c|}{ Não se exigia tratamento dos resíduos sólidos. } & Os resíduos sólidos devem ser tratados. \\
\hline \multicolumn{2}{|c|}{ Não refere à gestão dos resíduos perigosos. } & $\begin{array}{l}\text { São obrigatórios o tratamento e a disposição em aterro Classe I de } \\
\text { produtos contendo: hormonais, antimicrobianos, citostáticos, } \\
\text { antineoplásicos, imunossupressores, } \\
\text { digitálicos, imunomoduladores e anti-retrovirais e as embalagens } \\
\text { primárias que entrarem em contato. }\end{array}$ \\
\hline  & $\begin{array}{l}\text { Exigia-se a elaboração do plano de radioproteção } \\
\text { para os resíduos contendo radioisótopos. }\end{array}$ & Não faz menção sobre o plano de radioproteção. \\
\hline \multirow{3}{*}{ 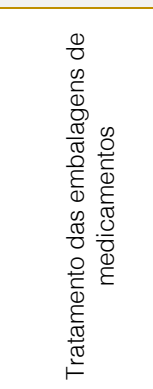 } & $\begin{array}{l}\text { Não exigia tratamento para as embalagens de } \\
\text { produtos químicos que apresentem periculosidade. }\end{array}$ & $\begin{array}{l}\text { As embalagens que entraram em contato com os produtos que } \\
\text { contenham risco devem ser submetidas à limpeza com técnica } \\
\text { validada antes da disposição final. }\end{array}$ \\
\hline & $\begin{array}{l}\text { Não constava a possibilidade de reciclagem das } \\
\text { embalagens de produtos não perigosos. }\end{array}$ & $\begin{array}{l}\text { Rejeitos de embalagem medicamentos que não apresentem riscos } \\
\text { poderão ser reciclados. }\end{array}$ \\
\hline & $\begin{array}{l}\text { Não era permitido o reaproveitamento das } \\
\text { embalagens para acondicionamento dos resíduos. }\end{array}$ & $\begin{array}{l}\text { Permite-se o uso das embalagens para o acondicionamento dos } \\
\text { resíduos, desde que se considere a compatibilidade entre esses. }\end{array}$ \\
\hline
\end{tabular}


Por fim, a nova legislação baseia-se no princípio de que as excretas de pacientes tratados com antineoplásicos só serão lançadas na rede de esgoto que atendam as normas da concessionária ou serão lançadas em corpos hídricos após tratamento prévio. Ora, sabendo que do total de 5.564 municípios, em 2008, apenas 3.069 possuem rede de esgoto, e somente 1.587 municípios realizam tratamento (RODRIGUES, 2011), pode-se afirmar que tratamento de esgoto não é a realidade brasileira, e será necessária mais fiscalização para se evitar a contaminação das águas por antineoplásicos.

\section{CONCLUSÕES}

A atualização da normativa buscou principalmente adequar às novas tecnologias disponíveis para a gestão dos resíduos. Notase que os artigos do dispositivo legal que referenciavam outras normas tiveram as devidas referências substituídas, conforme

\section{REFERENCIAS}

[1] Anvisa. Agência Nacional de Vigilância Sanitária. Consulta discute resíduos de serviços de saúde. Disponível em: <http://portal.anvisa.gov.br/noticias>. Acesso em: abr. 2018.

[2] Brasil. Agência Nacional de Vigilância Sanitária. RDC № 222, DE 28 DE MARÇO DE 2018. Regulamenta as Boas Práticas de Gerenciamento dos Resíduos de Serviços de Saúde e dá outras providências. Diário Oficial da República Federativa do Brasil. Brasília, DF, 2018.

[3] Brasil. Agência Nacional de Vigilância Sanitária. RDC № 306, DE 7 DE DEZEMBRO DE 2004. Dispõe sobre o Regulamento Técnico para o especificado ou de acordo com normas ambientais vigentes. Com isso, mantém-se a norma atualizada, porém, percebe-se que as decisões sobre alguns assuntos serão abordadas em outras instâncias.

Apesar de incluírem as características de carcinogenicidade, teratogenicidade e mutagenicidade aos resíduos medicamentosos, não foi exigida a descrição dessas particularidades na rotulagem dos produtos, assim como a descrição das características de compatibilidade necessárias para a prevenção dos riscos de acidentes, em caso de mistura.

Também não se definiu como será o descarte de fármacos. Já que se mantiveram as escolhas pelo gerenciamento desses resíduos a cargo dos responsáveis pelos estabelecimentos farmacêuticos. Isso não favorece as ações de preservação do meio ambiente, principalmente àquelas relacionadas à $L R$ e ao aproveitamento energético.

gerenciamento de resíduos de serviços de saúde. Diário Oficial da República Federativa do Brasil. Brasília, DF, 2004.

[4] Bardin, L. Análise de conteúdo. Lisboa: Edições 70, 279 p, 2011.

[5] Oliveira, D. C. Análise de conteúdo temático-categorial: uma proposta de sistematização. Revista de Enfermagem. Universidade Estadual do Rio de Janeiro, p. 569 576, out/dez de 2008.

[6] Rodrigues, C. M. Rede coletora de esgoto. Atlas do Saneamento 2011. Disponível em: <https://biblioteca.ibge.gov.br/visualizacao/livros/liv 53096_cap8.pdf>. Acesso em abr. 2018. 


\title{
Bapítulo 17
}

\section{CARNAVAL DE MANAUS: A DESTINAÇÃO FINAL DOS RESIDUUOS SOLIDOS PRODUZIDOS NO DESFILE DAS ESCOLAS DE SAMBA DO GRUPO ESPECIAL}

\author{
Davi do Socorro Barros Brasil \\ Flávia Karenine Silva da Ponte \\ Tales Vinicius Marinho de Araújo \\ Anne Marcelle Guimarães Sales \\ Júlio Fabricio Soares Furtado Belém \\ Helen Rita Menezes Coutinho
}

Resumo: Os eventos que se apresentam nos calendários das grandes cidades, geralmente são bastante esperados e tem uma importante participação de moradores e turistas que apreciam festas como o Carnaval, folclore regional, aniversário da cidade, santo padroeiro e outros eventos que ficam registrados na cidade. Sabemos que estes acontecimentos trazem um legado importante para a cidade, mostrando pontos positivos como a vinda de turistas que despendem, gerando movimentação financeira, mas são marcados também de forma negativa pelos resíduos que ficam amontoados nas calçadas, córregos, ruas da cidade, mais especificamente em nossa pesquisa, no sambódromo de Manaus após o desfile das escolas de samba do grupo especial. Dessa forma, serão realizadas pesquisas antes, durante e após o evento acompanhando a destinação dos materiais utilizados no evento que através das alegorias, transformam papeis, plásticos, papelão, garrafas, artefatos e outros produtos em fantasias, combinação de cores e um espetáculo a céu aberto. Quanto às propostas sugeridas, a pesquisa busca uma medida efetiva de redução dos impactos ambientais, vivenciados constantemente pelos cidadãos de Manaus no período carnavalesco, onde o fluxo de resíduos aumenta muito. Dessa forma, a sugestão é que seja feita a coleta e separação dos resíduos para que possam ser descartados ou reaproveitados de maneira adequados e assim, minimizar os impactos causados pelos resíduos sólidos deixados pelo evento.

Palavras - Chave: Evento. Resíduos Sólidos. Meio Ambiente. 


\section{INTRODUÇÃO}

O Carnaval é a festa que para Braga (1983), celebra a sobrevivência dos povos, cultua Ísis e homenageia Dionísio, até mesmo considerada como "festas inocentes" e dos doidos durante a Idade Média. O carnaval no Brasil originou-se com o entrudo, evento onde as pessoas brincavam com água, farinha, cal e outras substâncias que molhavam e sujavam os brincantes, manifestações estas nada tranquilas. Depois vieram os ranchos e em seguida, tivemos os blocos de carnaval, que eram constituídos por parte da população mais pobre que residiam em morros e subúrbios cariocas (SANCHES, 1999).

Sales (2008) discorre que em Manaus, como na maioria das grandes cidades brasileiras, o carnaval teve seu começo estritamente nos salões, passando para o entrudo. As festas ocorriam ao redor das mansões dos ricos da borracha, nas ruas com as "batalhas de confete" e nos clubes como Atlético Rio Negro Clube e Ideal Clube que até hoje cultivam os grandes bailes. A presente pesquisa vem contribuir de forma significativa sobre os impactos positivos causados pelos eventos, e aos poucos vêm sendo inseridos no campo de estudos científicos os impactos sociais, culturais e ambientais que favorecem 0 desenvolvimento sustentável da localidadesede, como afirmam Andersson e Lundberg (2013). Já quanto aos impactos negativos, Zanella (2008) indica o acúmulo de pessoas, a poluição, a violência e a geração de resíduos, que Mortean (2010) considera como um dos principais impactos dos eventos.

A gestão e a aplicabilidade dos resíduos de forma produtiva podem tornar-se elementos importantes, se utilizados na logística reversa pelos próprios grêmios recreativos ou encaminhados para diversos tipos de reciclagem, de acordo com o material apresentado.

Diante do exposto, esta pesquisa tem a seguinte problemática: O carnaval é um importante evento cultural e econômico para a cidade de Manaus. Analisando a gestão dos resíduos sólidos produzidos pelo desfile das Escolas de Samba de Manaus do grupo especial, como podemos descrever os impactos ambientais que podem ocorrer com o descarte inadequado dos resíduos sólidos originados pelo evento?

\section{METODOLOGIA}

A presente pesquisa utilizou-se de método de pesquisas bibliográficas e documental, através de matérias em jornais, documentos relacionados à produção e destinação dos resíduos sólidos gerados no carnaval da cidade. Foram disponibilizadas informações pelo IMPLURB - Instituto Municipal de Planejamento Urbano, que hoje responde pela coleta dos resíduos retirados da cidade de Manaus, sendo feitas ações especificas neste período do evento. Este estudo abrange sobre os resíduos oriundos das agremiações no dia do desfile das Escolas de Samba do Grupo Especial do ano de 2018, ocorrido no dia 10 de fevereiro.

Esta pesquisa tem como prioridade buscar responder questionamentos sobre o "como" e o "porquê" dos resíduos sólidos serem mal utilizados, ou mesmo nem reutilizados no processo do Evento, sendo o método de procedimento o Monográfico, ou Estudo de Caso, uma vez que perscrutará a respeito dos resíduos sólidos produzidos no carnaval dos Grêmios Recreativos de Escolas de Samba do Grupo Especial realizado no sambódromo de Manaus.

Os registros fotográficos foram feitos antes, durante e após o dia do evento. Nesta pesquisa utilizaremos a abordagem qualitativa por apresentar os fatos de forma descritiva, buscando uma compreensão e interpretação de acordo com os sujeitos. Quanto aos métodos a serem adotados, optamos pelo Dedutivo, onde analisamos do geral ao especifico, chegando a uma conclusão que pressupõe a generalização de conhecimento evidenciado.

No Contexto investigativo, foram investigados os tipos e como são descartados os resíduos sólidos, para assim analisarmos os diversos itens que podem influenciar no processo.

Quanto aos procedimentos e instrumentos da coleta de dados, foi utilizado o método de observação in loco que permite a evidência de informações, material e fatos que segundo Marconi \& Lakatos (1999), é um tipo de pesquisa que faz uso de determinados aspectos da realidade. Quanto ao material e recursos utilizados para coleta de dados, foram utilizados papel, caneta, lápis, livros, câmera fotográfica, jornais e computador. 


\section{RESULTADOS E DISCUSSÃO}

Nesta etapa da pesquisa são apresentados os resultados obtidos no presente estudo, baseados no objetivo proposto e na bibliografia utilizada sobre o tema em questão. Inicialmente, apresentam-se as matérias-primas utilizadas na confecção de fantasias e alegorias pelos grêmios recreativos e quanto isso produz de resíduo sólido. Em seguida, as sugestões, de acordo com os objetivos propostos no desenvolvimento desta pesquisa.

Quando se decide por abordar um conteúdo de forma mais profunda, há sempre algo que causa uma inquietação para que possamos nos interessar e entrar no universo da pesquisa, dessa forma todo o resíduo sólido que é produzido no desfile de escolas de samba no sambódromo há tempos são discutidos por todos os prejuízos que causam ao meio ambiente e à população. Torna-se cada vez mais evidente que a sustentabilidade e o gerenciamento adequado dos resíduos sólidos podem reduzir significativamente os impactos ao ambiente e à saúde. Nos países mais ricos que geram maiores quantidades de resíduos e de lixo, existe mais capacidade de equacionamento da gestão, por um somatório de fatores que incluem recursos econômicos, preocupação ambiental da população e desenvolvimento tecnológico. Em cidades de países em desenvolvimento com urbanização muito acelerada, verificam-se déficits na capacidade financeira e administrativa dessas em prover infraestrutura e serviços essenciais como água, saneamento, coleta e destinação adequada do lixo e moradia, e em assegurar segurança e controle da qualidade ambiental para a população.

Esta pesquisa foi relevante para a sociedade como um todo, pois diariamente resíduos são lançados em locais públicos, incluindo parques, ruas, calçadas, vielas, sendo que o objeto aqui estudado tem uma sazonalidade e localidade especifica nos eventos da cidade de Manaus e foi restringido ao dia especifico em que os grêmios recreativos escolas de samba do grupo especial desfilam no sambódromo da capital. Mas não podemos esquecer que o carnaval como um todo acumula cerca de 240 toneladas de lixo que são retiradas pela Secretaria Municipal de Limpeza e Serviços Públicos (Semulsp), onde está incluído bandas de Carnaval pela cidade. Duas das Bandas mais populares de Manaus, Banda da Bica e Banda do
Boulevard, foram responsáveis por 40 toneladas de lixo. No geral, apesar do número elevado, foi reduzido o número de resíduos acumulados neste período, pois $80 \%$ das bandas cumpriram a nova Lei de limpeza pública municipal que diz no Art 8 № âmbito do Sistema de Limpeza Urbana, são considerados usuários:

I - o munícipe - usuário, entendido como a pessoa física ou jurídica que gerar resíduos ou auferir proveito decorrente da prestação dos serviços de limpeza urbana;

II - a pessoa jurídica responsável pela coleta, remoção e triagem de resíduos é usuária em relação aos operadores de tratamento e destinação final;

III - a Prefeitura Municipal de Manaus, representando a coletividade ou parte dela.

Dessa forma, cada grêmio, bloco ou banda de carnaval deve ser responsável pela coleta, remoção e triagem dos seus resíduos, embora a administração pública municipal tenha a responsabilidade de gerenciar os resíduos sólidos, desde a sua coleta até a sua disposição final, que deve ser ambientalmente segura.

A finalidade da pesquisa é responder ao problema inicial, para tanto é preciso que o pesquisador produza hipóteses ou questões e posteriormente desenvolva a coleta de dados imprescindíveis (GERHARDT E SILVEIRA, 2009) e este estudo procurou entender de que modo seria possível reaproveitar internamente os resíduos sólidos e gerados pelo dia de desfile das escolas de samba do grupo especial, pois alguns resíduos sólidos como isopor, plástico, ferro, papel e seus derivados que são difíceis de se decomporem e geram um aumento significativo de geração de resíduos, os quais podem ter como destinação final, um tratamento e/ou reuso.

Compreender a destinação final dos resíduos sólidos produzidos pelo carnaval no desfile dos Grêmios Recreativos de Escolas de Samba do Grupo Especial realizado no sambódromo de Manaus está como objetivo mais holístico da pesquisa, porque dessa forma saberemos o que é feito do produto consumido (fantasias e alegorias), até o momento em que a coleta municipal é feita. Neste processo, observamos que a logística reversa é um trabalho a ser desenvolvido e incluído para que se minimizem os impactos causados ao ambiente. 
Dentre os resultados, expomos também como objetivos mais direcionados a identificação das matérias-primas utilizadas no evento que geram entulhos e acúmulos em torno do sambódromo e principalmente na frente dos galpões de confecções de alegorias que causam os resíduos, como nas figuras a seguir. Se houver um conhecimento prévio sobre esses materiais, poderemos ver o que poderá ser feito durante todo o processo de uso até o direcionamento do descarte ou aproveitamento do mesmo.

Figura 01: Resíduos Sólidos em torno ao Sambódromo de Manaus

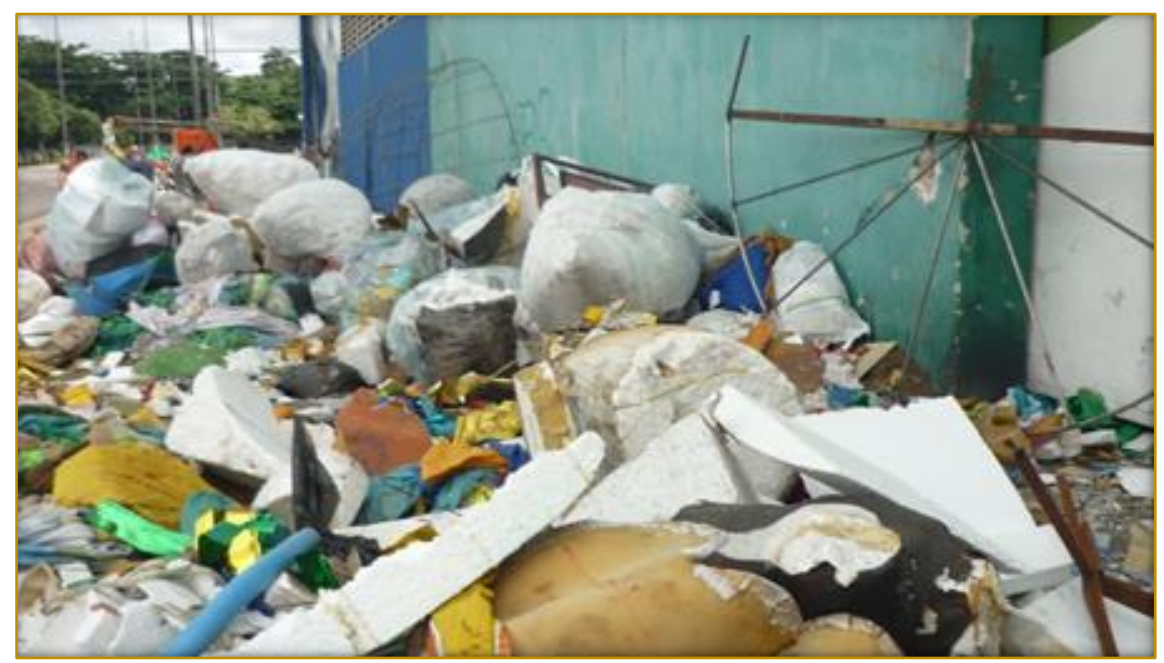

Fonte: Própria autora. Fev, 18.

Figura 02: Resíduos Sólidos em torno ao Sambódromo de Manaus

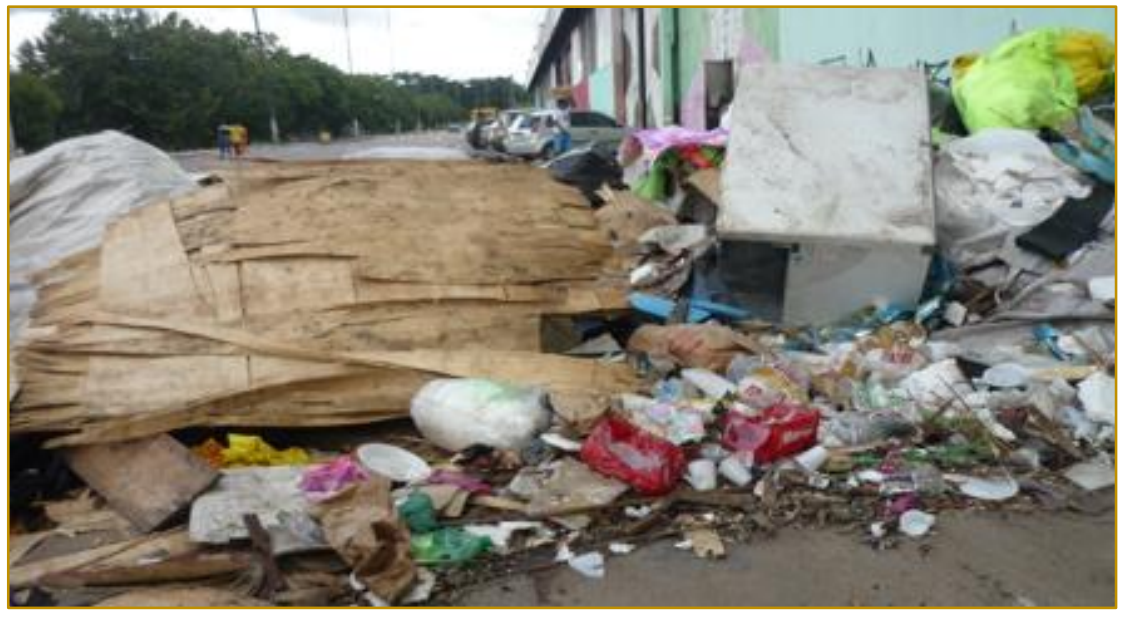

Fonte: Própria autora. Fev, 18. 
Figura 03 - Resíduos Sólidos em torno ao Sambódromo de Manaus

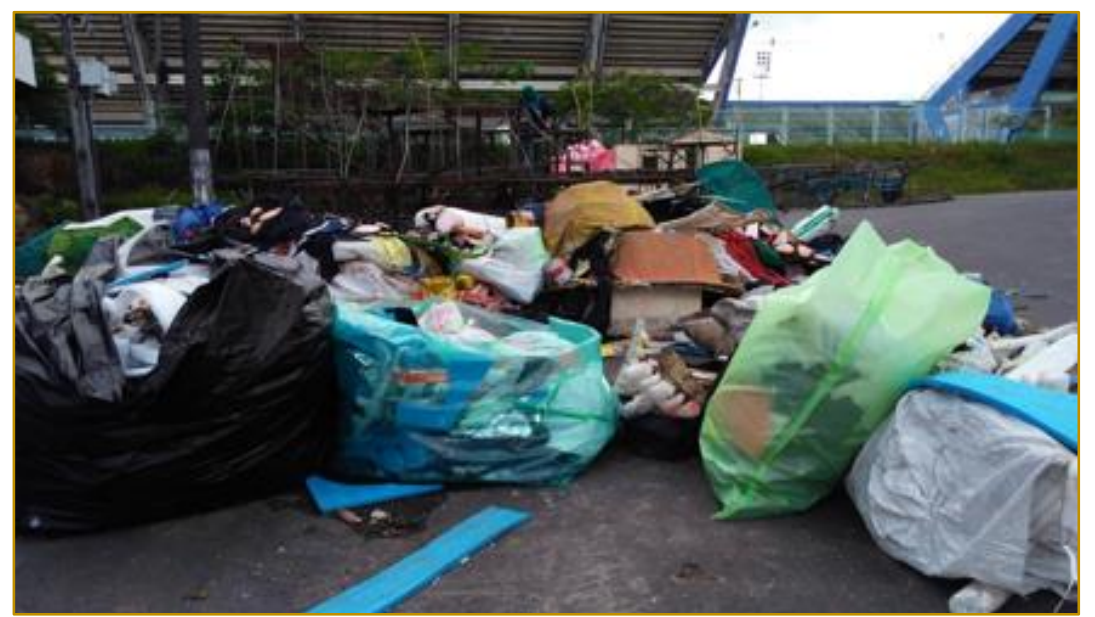

Fonte: Própria autora. Fev, 18.

Desde que iniciaram as festas de carnaval em Manaus, ainda quando os desfiles eram feitos na Avenida Eduardo Ribeiro, não existia utilização e variedade de materiais como nos dias atuais para a confecção das alegorias, o que não gerava tantos resíduos sólidos nas ruas do centro de Manaus e temos que colocar como um fator relevante a restrição de tipos de materiais que eram utilizados e o comportamento das pessoas daquela época.

Com a mudança para a Avenida Djalma Batista e o crescimento dos desfiles das escolas de samba, o evento começou a gerar muitos resíduos sólidos no entorno da avenida, no entanto naquela época existia o reaproveitamento de matérias-primas, pois ao termino do desfile as pessoas da comunidade se uniam em busca de materiais que seriam utilizados em outro ano.

Hoje, o que se observa é a continua ausência de um planejamento por parte dos grêmios e dos órgãos públicos responsáveis, com aquilo que muitos podem chamar de lixo, mas que se trata de resíduos sólidos que podem ser utilizados de diversas formas.

Para compreendermos a destinação do resíduo foi necessária uma investigação a partir da quantidade de materiais utilizados nas agremiações e o número de brincantes que trazem para o desfile. Desfilaram no sambódromo oito agremiações com a seguinte quantidade de componentes: A Grande Família (3.500), Reino Unido da Liberdade (4.500), Mocidade Independente de Aparecida (3.200), Unidos da Alvorada (2900), Vitória Régia (3.000), Vila da Barra (2.900), Sem Compromisso (2.500) e Andanças de Cigano (2.300), formando um total de 24.800 foliões e mais de 50 toneladas de material utilizado. Além dos foliões, temos que inserir no estudo os carros alegóricos cada agremiação traz em média entre 2 a 5 alegorias. Dessa forma, Jardim et al. (1995), citam que as características dos resíduos sólidos urbanos são influenciadas por vários fatores, como número de habitantes, poder aquisitivo, nível educacional, hábitos e consumos da população, condições climáticas e sazonais.

O desfile apresenta uma variável de materiais como ferro, madeira, acetato, tecidos, plásticos, papelão, pedrarias, vidros, espelhos, plumas, penas, produtos descartáveis que hoje são reutilizados como descartáveis, CDs, papéis de diversas gramaturas, papelão, entre outros arrecadado pela própria comunidade com o objetivo de reduzir gastos.

Esse material, segundo a assessoria da SEMULSP (Secretaria Municipal de Limpeza e Serviços Públicos), no dia do desfile das escolas de samba do grupo especial gera cerca de 12 a 20 toneladas de resíduos que são coletados por 120 funcionários da prefeitura que também auxiliam no processo de pesagem e remoção ao aterro sanitário de Manaus. A secretaria ainda esclarece que não há um serviço de coleta seletiva e que apenas as ferragens são levadas aos galpões dos grêmios, não sendo reutilizados os demais materiais.

As ferragens que constituem a estrutura dos carros alegóricos e algumas madeiras, como o compensado, são também reutilizadas, pois representam muito no orçamento do evento, 
dessa forma podemos considerar a logística reversa, como mencionado na figura 10.

Plumas, penas e pedrarias são os materiais mais caros também entram na lista de reaproveitáveis, no entanto são guardadas pelos próprios foliões que investem no material e não pela agremiação, somente será investimento da agremiação, caso seja um item obrigatório do desfile como, por exemplo, porta-bandeira e mestre-sala, baianas, entre outros itens. Entretanto, cerca de 70 a $80 \%$ do material em Manaus, de acordo com a observação in loco e dos dados da SEMULSP, vai para o lixo.

Foi observado que durante a festa de Momo há um aumento significativo de resíduos sólidos em torno do sambódromo de Manaus e durante todo o desfile. Onde acontece o desfile ficam "pedaços" de fantasias e alegorias, apesar de a prefeitura ter uma equipe especifica para o local do evento. No dia posterior ao evento podemos observar que as alegorias ficam na área denominada dispersão ou nas ruas adjacentes ao sambódromo, conforme Figuras 18, 19 e 20.

Figura 04: Resíduos Sólidos no entorno do Sambódromo

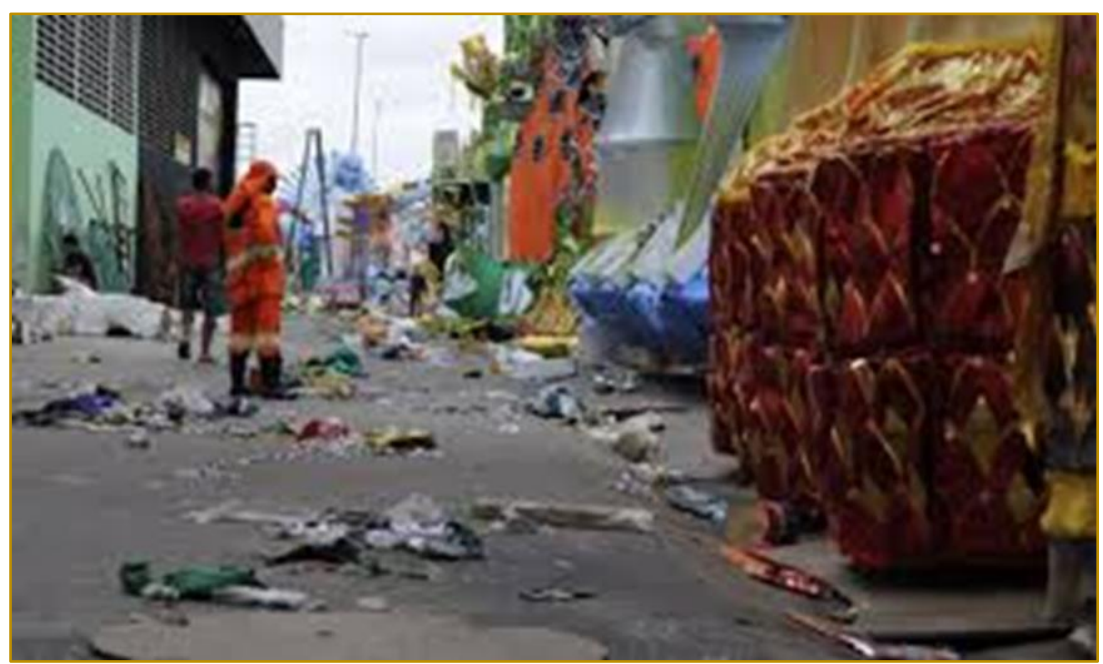

Fonte: D24AM - 5/04/17

Figura 05: Resíduos Sólidos no entorno do Sambódromo

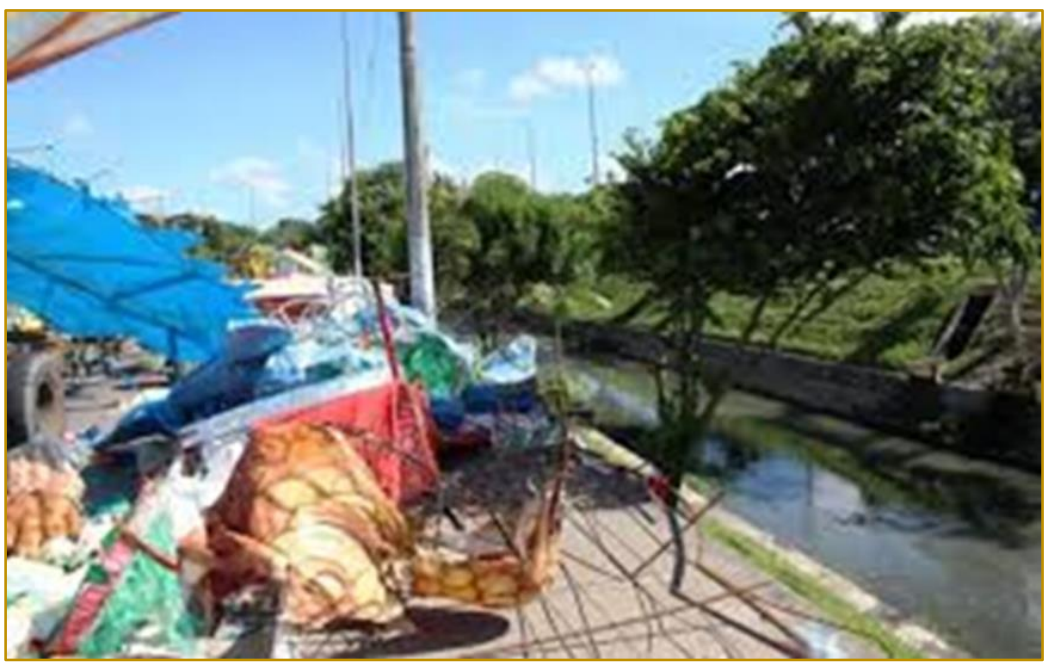

Fonte: D24AM - 5/04/17 
Figura 06: Resíduos Sólidos no entorno do Sambódromo

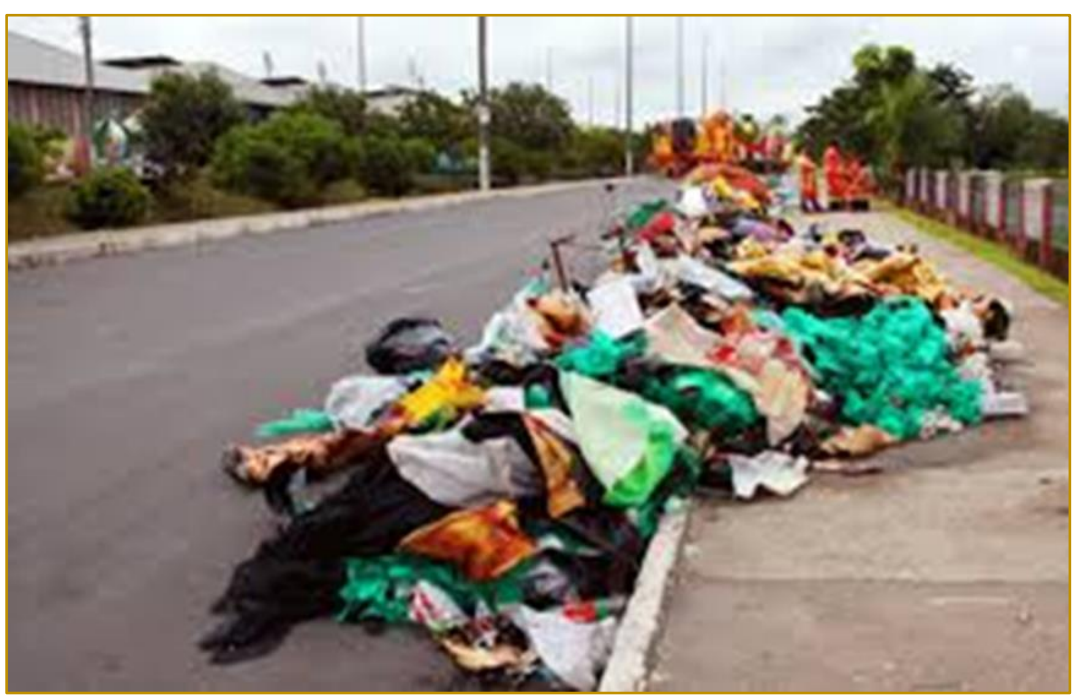

Fonte: D24AM - 5/04/17

A gestão e a disposição inadequada dos resíduos sólidos causam impactos socioambientais, tais como degradação do solo, comprometimento dos corpos d'água e mananciais, intensificação de enchentes, contribuição para a poluição do ar e proliferação de vetores de importância sanitária nos centros urbanos e catação em condições insalubres nas ruas e nas áreas de disposição final.

Mandelli (1997) aponta que a gestão dos resíduos sólidos compreende a definição de ações conjuntas articuladas por normas, políticas, planejamento operacional e financeiro fundamentadas em critérios sanitários, ambientais e sociais, políticos, técnicos, educacionais, culturais, estéticos e econômicos, para a geração, o manejo, o tratamento e a disposição final dos resíduos sólidos.

Em busca de minimizar os problemas causados pela falta de separação adequada dos resíduos, a sugestão é que haja um trabalho de sensibilização em todos os grêmios para que na dispersão tenha uma equipe para separar e, posteriormente, faça o tratamento adequado para cada tipo de material coletado. Para Gentil (2008), o circuito tem um melhor desenvolvimento se todas as etapas forem realizadas no mesmo espaço com a criação de centros de triagem facilitando o transporte do material, resultando possivelmente em redução do orçamento financeiro para execução da gestão. Gentil
(2008) e Araújo (2011) também destacam a inclusão de cooperativas de catadores como mão de obra especializada porque os catadores buscam produtos específicos que podem trazer uma renda ou mesmo lucro em sua coleta e não tem conhecimento suficientes para a separação adequada dos resíduos. Outro autor que propõe uma sequência de ações como prevenção e redução de resíduos, reaproveitamento através da coleta seletiva, tratamento e disposição final para uma correta gestão de resíduos é Valle (2004). A gestão de resíduos sólidos traz consigo a redução da poluição ambiental e também garante a longo prazo uma estabilização da demanda por recursos naturais e do volume final de resíduos não precisando extrair a matéria-prima da natureza.

De Conto (2004) argumenta que, para uma gestão de resíduos sólidos, seja nos eventos ou nos empreendimentos turísticos, há necessidade da mudança do comportamento de todos os envolvidos, organização, prestadores de serviços, participantes, iniciativas privadas e públicas. Além da importância de uma legislação atuante e preventiva em prol da sustentabilidade local, seja através do Turismo ou de realização de eventos.

O evento de Carnaval é considerado um grande gerador de resíduos solido, dessa forma há a necessidade de pôr em prática o Programa de Gestão de Resíduos Sólidos. 
Alberguini (2008) cita três medidas urgentes para diminuir a quantidade de lixo e o impacto dos resíduos no meio ambiente que são a coleta seletiva, a reciclagem de materiais e a compostagem, que devem ser realizados de forma integrada, dentro de um programa contínuo, com apoio do poder público municipal, de empresas e conscientização da população. Segundo Alberguini (2008, p. ),

Coleta seletiva é um sistema de recolhimento de materiais recicláveis: papéis, plásticos, vidros, metais e orgânicos, previamente separados na fonte geradora e que podem ser reutilizados ou reciclados. A coleta seletiva funciona, também, como um processo de educação ambiental na medida em que sensibiliza a comunidade sobre os problemas do desperdício de recursos naturais e da poluição causada pelo lixo. Reciclagem é o processo de transformação de um material, cuja primeira utilidade terminou, em outro produto. A compostagem é o processo de transformação de materiais grosseiros, como palhada e estrume, em materiais orgânicos utilizáveis na agricultura.

Os resíduos sólidos urbanos são uma das principais preocupações dos gestores públicos municipais, no que tange à sua gestão e gerenciamento. Pois exigem dos municípios medidas imperativas e adequadas para gerenciá-los diante das obrigações legais, com vistas à minimização dos impactos sociais, econômicos e ambientais. Os lixões e aterros estão numa situação cada vez mais complicada pois o lixo oriundo do Carnaval causa graves impactos no meio ambiente e gera um alto custo extra de coleta para a prefeitura, pago com recursos públicos. É possível e necessário que o folião que vai curtir uma programação mais tranquila, aproveite a festa de Carnaval e também ter atitudes sustentáveis.

No quadro hoje em que ocorre o desfile das escolas de samba, não há um espaço suficiente para dispor dos resíduos e somente depois separa-lo, dessa forma a pesquisa nos fez buscar por soluções mais eficazes do que a simples deposição dos mesmos no meio ambiente. Para isso, buscamos abordagens para saber uma providência para cada solução (Valle, 1995), como mostra o quadro 1, a seguir:

Quadro 1: Soluções para destinação e respectivas providências

\begin{tabular}{|c|c|}
\hline Soluções & Providências \\
\hline Minimização & $\begin{array}{l}\text { Preventiva, orientada para reduzir o volume e o impacto causado pelos } \\
\text { resíduos. A minimização é feita através de modificações no processo } \\
\text { produtivo, ou pela adoção de tecnologias limpas, mais modernas que } \\
\text { permitem, em alguns casos, eliminar completamente a geração de materiais } \\
\text { nocivos. Não se considera a redução do volume de resíduos como } \\
\text { minimizacão sem a redução de sua toxicidade. }\end{array}$ \\
\hline Reciclagem & $\begin{array}{l}\text { Reciclar é refazer o ciclo, permite trazer de volta à origem, sob a forma de } \\
\text { matérias-primas, aqueles materiais que não se degradam facilmente e que } \\
\text { podem ser reprocessados, mantendo suas características básicas. }\end{array}$ \\
\hline $\begin{array}{l}\text { Recuperação dos resíduos } \\
\text { gerados }\end{array}$ & $\begin{array}{l}\text { Abordagem orientada para extrair valores materiais ou energéticos dos } \\
\text { resíduos, contribuindo para reduzir os custos de destinação dos resíduos. }\end{array}$ \\
\hline
\end{tabular}
Fonte: Valle, 1995

Diante deste exposto vemos que o método da prevenção sempre é o mais adequado porque faz com que se tenha menos trabalho e custo. No caso dos resíduos sólidos do desfile, há uma necessidade de reunir com os organizadores do evento para que se fação um trabalho onde sejam adquiridos materiais menos poluentes e que possam ser minimizados os focos tóxicos.

$\mathrm{Na}$ reciclagem podem ser adquiridos produtos que após o uso primário, possam ser reaproveitados em outras alegorias, como por exemplo, tecidos, plásticos ou até mesmo sobras de acetatos. Quanto à recuperação dos resíduos gerados, temos o ferro como maior produto recuperado para ser utilizado novamente, pois além de ter um custo alto, ele é aproveitado quase que totalmente, mesmo em um novo processo na confecção de fantasias e alegorias, como mostra a Figura 07, a seguir: 
Figura 07 - Transformação dos resíduos sólidos em matéria-prima secundária.

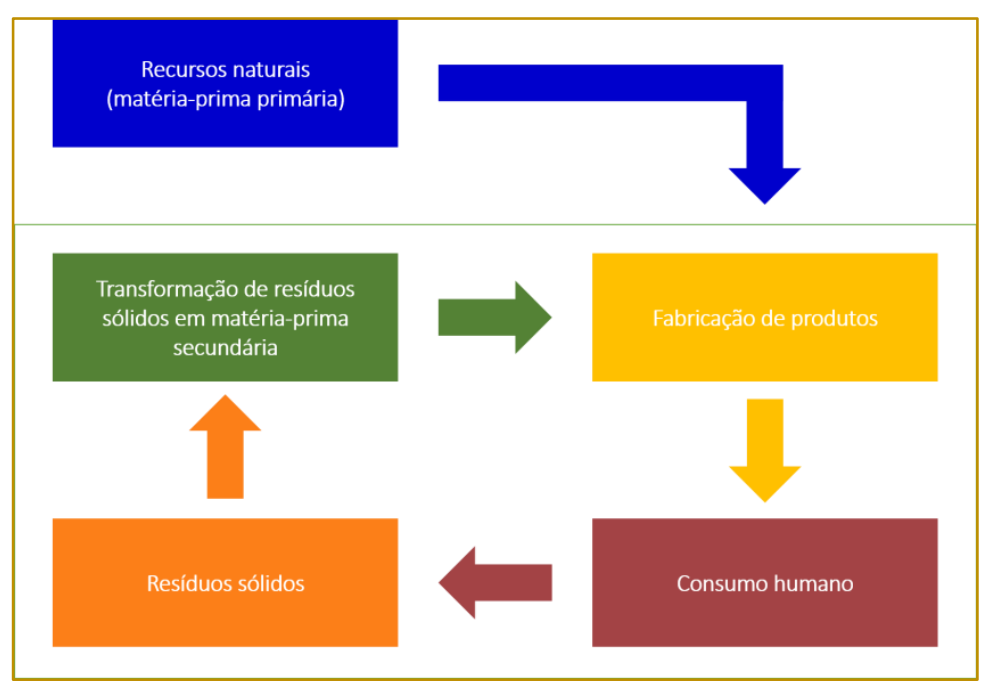

Fonte: Própria autora, 2018.

Em todo este processo que antecipa a separação dos resíduos sólidos, são necessárias ações e sensibilização por parte de todos os envolvidos neste processo para que apresente resultados positivos, como destaca Ceron (2014, p. 1):

A reflexão sobre as práticas sociais, em um contexto marcado pela degradação permanente do meio ambiente e do seu ecossistema, envolve uma necessária articulação com a produção de sentidos sobre a educação ambiental. A dimensão ambiental configura-se crescentemente como uma questão que envolve um conjunto de atores do universo educativo, potencializando o engajamento dos diversos sistemas de conhecimento, a capacitação de profissionais e a comunidade universitária numa perspectiva interdisciplinar. Nesse sentido, a produção de conhecimento deve necessariamente contemplar as inter-relações do meio natural com o social, incluindo a análise dos determinantes do processo, o papel dos diversos atores envolvidos e as formas de organização social que aumentam o poder das ações alternativas de um novo desenvolvimento, numa perspectiva que priorize novo perfil de desenvolvimento, com ênfase na sustentabilidade socioambiental.

A separação dos resíduos oriundos das agremiações são de grande volume, como já citados durante esta pesquisa. Para que haja uma separação e que traga retornos positivos serão sugeridos que tenham cinco caminhões baús que funcione como "cestões" para cada tipo de material como papel (azul), plástico (vermelho), vidro (verde), metal (amarelo), ao termino do desfile de cada agremiação e dessa forma, a separação otimizada para que ao término de todos os desfiles, os profissionais técnicos vejam todo o material e dêem o seu destino, inclusive reaproveitamento para outras escolas de samba ou até mesmo para a mesma, com a finalidade dos produtos de forma diferente, como mostra a Figura 08. 
Figura 08: Caminhões baús sugeridos para separação de resíduos sólidos no evento.

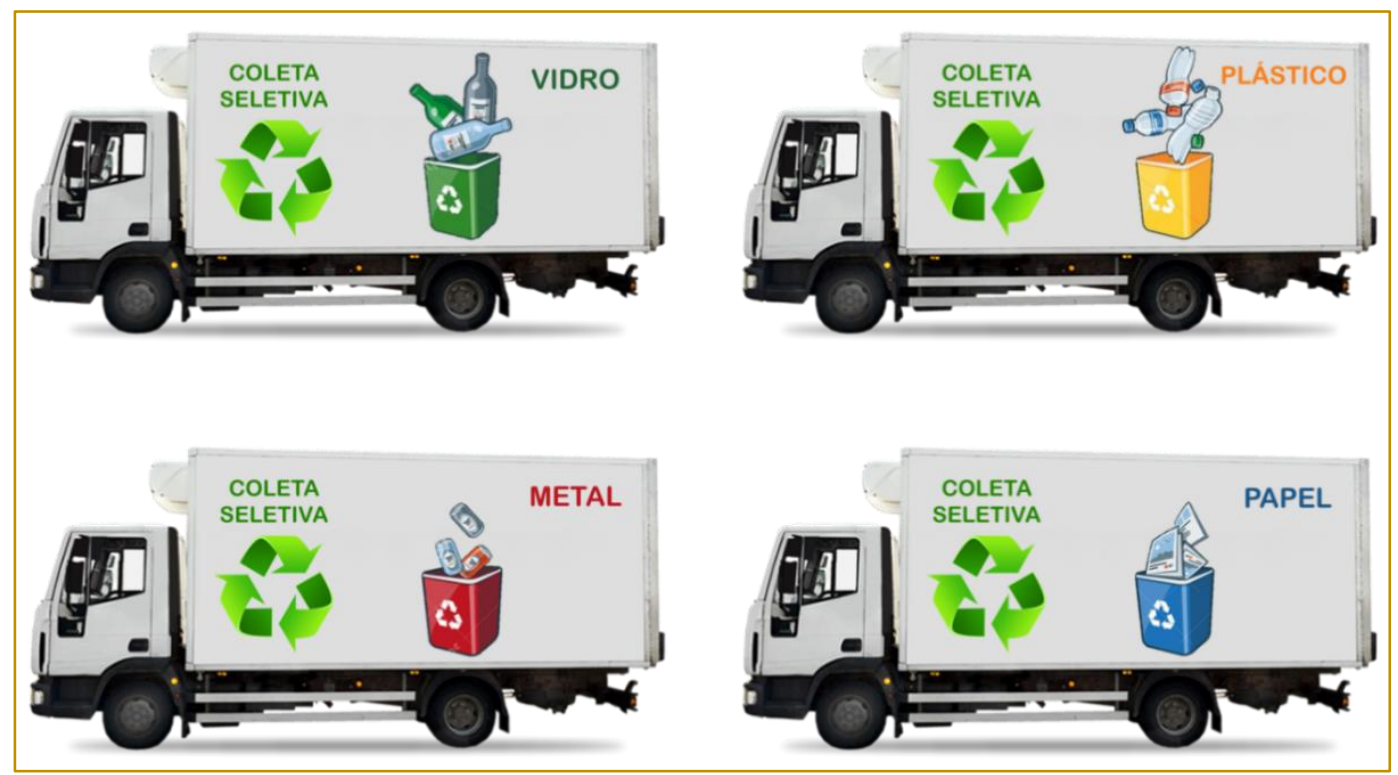

Fonte: Própria autora, nov 2018

Pouco se perde dos adornos de uma grande escola de samba passado o desfile na avenida. Os diretores e administradores do carnaval são unanimes em dizer que no lixo do carnaval há uma enorme riqueza, além de todo o aproveitamento que é oferecido. Para que se alcance o sucesso na interação sociedade e poder público como sugere o texto a seguir:

A política nacional de manejo de resíduos sólidos urbanos será tanto mais bem sucedida enquanto tiver como alvos: reduzir a quantidade e a nocividade dos resíduos sólidos; eliminar os prejuízos à saúde pública e ao meio ambiente por eles causados; formar uma consciência comunitária sobre a importância da opção pelo consumo de produtos e serviços que não afrontem o meioambiente e/ou que sejam recicláveis mediante um manejo adequado; e gerar benefícios sociais e econômicos tanto aos municípios que se dispuserem a licenciar instalações para a destinação correta dos resíduos, quanto a centenas de milhares de catadores, bem como para empresas de reciclagem. (Kapaz, 2009, pg. 45)

Ainda será necessário um trabalho anterior ao desfile para que a equipe tenha conhecimento de todo tipo de matéria-prima utilizada, permitindo que desde o processo de uso ao direcionamento do descarte ou aproveitamento do mesmo, seja analisado da melhor forma.

Por fim, se faz necessário um trabalho multidisciplinar para que as sugestões e propostas de melhorias na destinação dos resíduos sólidos às partes envolvidas na organização do evento sejam aceitas, pois dessa forma todos estarão incluídos nas mudanças que trarão impactos positivos para o evento, podendo ser através de diversas formas de comunicação e auxilio com os órgãos públicos.

\section{CONCLUSÕES}

O consumo exacerbado de produtos e materiais de diversas espécies e origens proporciona um aumento acelerado de resíduos liquido e sólidos no Brasil e no Mundo, trazendo transtornos ambientais e de saúde para a população, que muitas vezes é a maior ou a principal fonte geradora desses resíduos. Esse volume de resíduos das cidades é grande e a quantidade de dejetos tem a tendência de cada vez mais aumentar, trazendo exaustão ao ambiente natural.

Dentro desse processo em originar resíduos, estão os eventos pelo mundo todo que ocasionam papeis, plásticos, alumínio, líquidos e outros materiais, no entanto tem sua economia impulsionada por acontecimentos religiosos, culturais, profissionais, comerciais, científicos e dessa forma, aumentam o lixo e sua composição, pois muitos desses materiais não se deterioram rapidamente.

Falar de reaproveitamento de material em um país que tem a cultura de jogar fora diversos tipos de matéria-prima não pode e nem deve 
ser analisada de forma isolada, pois inclui diversos processos, incluindo o social, cultural, ambiental e logístico.

Neste trabalho, a logística reversa e a coleta seletiva tornam-se fundamentais, já que hoje somente pequena parte do material são reutilizados no desenvolvimento das alegorias. Sendo necessário, o reuso de

\section{REFERÊNCIAS}

[1] Andersson, T., \& Lundberg, E. (2013). Commensurability and sustainability: triple impact assessment of a tourism event. Tourism Management, 37:99 - 109.

[2] Braga, Genesino. Fastígio e sensibilidade do Amazonas de ontem. 2 ed. Manaus: Imprensa Oficial, 1983.

[3] Ceron, Luciano Peske. Educação ambiental e Reciclagem do Lixo. Disponível em:. Acesso em: 05 ago. 2015.

[4] Jardim, N. S. et al. Lixo Municipal: manual de gerenciamento integrado. São Paulo: IPT/CEMPRE, 1995.

[5] Kapaz, Emerson. Por uma Política Nacional de Resíduos Sólidos. Disponível em:. Acesso em: 12 fev. 2015.

[6] Marconi, M.A. \& Lakatos, E.M. Fundamentos da metodologia científica. 5 ed. SP: Atlas, 2003. materiais como plástico, papelão, isopor, entre outros para tornar o evento mais viável economicamente e ambientalmente correto.

É necessário que as sugestões sejam implantadas, melhorando os controles e ações desenvolvidas por parte dos coordenadores do evento e das agremiações.

[7] Mortean, Alan Frederico. Quantificação da produção de resíduos sólidos de eventos mais sustentáveis: estudo de caso da USP de São Carlos. Monografia apresentada a Graduação em Engenharia Ambiental da Universidade de São Paulo, 2010

[8] Sanches, Cleber. Fundamentos da cultura brasileira. Manaus: Travessia, 1999.

[9] Sales, Daniel. É tempo de sambar: história do carnaval de Manaus com ênfase às Escolas de Samba. Manaus: Editora Nortemania, 2008.

[10] Valle, C.E. Qualidade Ambiental: como ser competitivo protegendo o meio ambiente: (como se preparar para as Normas ISO 14000). São Paulo: Pioneira, 1995

[11] Zanella, Luiz Carlos. Manual de organização de eventos: Planejamento e organização. 4 ed. São Paulo: Atlas, 2008. 


\section{Bapítulo 18}

\section{PROPOSIÇÃO DE INDICADORES PARA AVALIAÇÃO DE IMPACTOS AMBIENTAIS CAUSADOS POR RESİDUOS DE ESTAÇÕES DE TRATAMENTO DE ESGOTO SANITÁRIO}

\section{Poliana Arruda Fajardo}

Nemésio Neves Batista Salvador

João Sérgio Cordeiro

Resumo: Com a possibilidade de geração de impactos ambientais negativos, as ETEs estão entre os empreendimentos que devem passar pelos processos de Avaliação de Impacto Ambiental e de licenciamento ambiental. O presente trabalho é resultante de uma pesquisa, cujo objetivo foi desenvolver instrumentos de auxílio à realização da Análise Ambiental Inicial em ETEs, em concordância com a NBR ISO 14001:2004 (Sistema de Gestão Ambiental), por meio de um estudo de caso, e visa contribuir para essa questão. Um dos instrumentos elaborados, bem como observações e fotografias permitiram o registro de aspectos, potenciais impactos e indicadores ambientais referentes aos resíduos gerados na ETE-Monjolinho, em São Carlos/SP, Brasil. Considera-se que estes resultados podem auxiliar a utilização e aprimoramento de Planos de Gestão Ambiental e, consequentemente, a utilização de estudos de impactos ambientais para além de processos de licenciamento.

Palavras-chave: EIA. ETE. Impacto Ambiental. Resíduos. 


\section{INTRODUÇÃO}

Um dos setores da gestão pública que mais têm chamado a atenção é o de saneamento básico, e entre seus integrantes, as Estações de Tratamento de Esgotos sanitários (ETEs). Isto porque as ETEs são importantes não somente sob o ponto de vista de saúde pública, por afastarem dos cidadãos o esgoto bruto com grandes quantidades de organismos patogênicos, como também porque são elementos fundamentais na gestão das cidades para a proteção e conservação dos recursos ambientais (FAJARDO e CORDEIRO, 2014).

As ETEs, no entanto, embora sabidamente concebidas para resolverem um problema de poluição ambiental e de saúde pública, também podem se tornar um grande problema para as administrações municipais e por isso devem receber especial atenção. Seus processos de tratamento geram resíduos que, aliados a possíveis falhas de equipamentos e de processo, podem provocar impactos ambientais [negativos] e também danos aos seus próprios operadores e circunvizinhança (FAJARDO e CORDEIRO, 2014).

Com a possibilidade de geração de impactos ambientais negativos, as ETEs estão entre os empreendimentos que devem passar pelos processos de Avaliação de Impacto Ambiental (AIA) e de licenciamento ambiental.

No Brasil, os processos de AIA e de licenciamento estão regulamentados pelas resoluções do Conselho Nacional de Meio Ambiente (CONAMA) № 001/1986, que exige a identificação, avaliação sistemática, definição de medidas mitigadoras (para impactos negativos) e a elaboração de um programa de acompanhamento e monitoramento dos impactos ambientais positivos e negativos, "indicando os fatores e parâmetros a serem considerados"; e a e № 237/1997, segundo a qual os órgãos ambientais competentes devem determinar a complexidade dos estudos exigidos para o licenciamento ambiental de empreendimentos e atividades, de acordo com a significância dos impactos.

Estas exigências estão em concordância com - Plano de Gestão Ambiental exigido em processos de AIA, após a aprovação de projetos, que é composto, segundo Sánchez (2013), por: plano de monitoramento e medidas mitigadoras, compensatórias e de valorização dos impactos benéficos.
Assim, o presente trabalho, resultante de uma pesquisa, cujo objetivo foi desenvolver instrumentos de auxílio à realização de Análise Ambiental Inicial em ETEs, em concordância com a NBR ISO 14001:2004 (Sistema de Gestão Ambiental), visa contribuir para esta questão.

Os instrumentos foram elaborados por meio de um estudo de caso realizado na ETEMonjolinho, São Carlos/SP, e então aplicados à referida ETE. Durante a elaboração e aplicação dos instrumentos, verificaram-se várias características, entre estas, aspectos e potenciais impactos ambientais associados aos resíduos gerados pelo tratamento da Estação, para os quais foram elaborados também indicadores ambientais.

Desta maneira, os resultados obtidos no que se refere aos resíduos da ETE-Monjolinho poderão colaborar para uma melhor utilização de Planos de Gestão Ambiental para além do processo de licenciamento, bem como contribuir para ações semelhantes em outras ETEs.

\section{MATERIAL E MÉTODOS}

A metodologia da pesquisa que originou este trabalho foi realizada em quatro etapas. $\mathrm{Na}$ primeira etapa, foi realizado embasamento teórico; na segunda, o conhecimento mais aprofundado da ETE-Monjolinho; na terceira, foram elaborados os instrumentos de Análise Ambiental Inicial e realizada sua aplicação à ETE-Monjolinho; e na quarta etapa realizaramse a exposição e discussão dos resultados, bem como as considerações finais do trabalho.

Embora haja semelhanças entre algumas partes dos instrumentos produzidos na terceira etapa (oito, no total, além de uma sugestão de capa para o processo), cada um possui características específicas de elaboração. Assim, o "Instrumento de auxílio à identificação de aspectos e impactos ambientais e elaboração de indicadores ambientais", que permitiu o registro de aspectos, potenciais impactos e indicadores ambientais, incluindo-se aqueles referentes aos resíduos gerados na ETE, foi elaborado utilizando-se como parâmetro um dos anexos contidos na NBR ISO 14004:2005, que é destinado a objetivo similar.

$\mathrm{Na}$ aplicação deste instrumento à ETEMonjolinho, foram consideradas as principais etapas do tratamento de esgoto sanitário 
realizado (Tratamento preliminar, reatores UASB, flotadores, desinfecção e centrífuga), além do esgoto sanitário tratado. Observações e fotografias produzidas durante a aplicação à ETE-Monjolinho deste e dos outros instrumentos elaborados também auxiliaram na obtenção dos dados referentes aos aspectos, impactos e indicadores ambientais.

\section{RESULTADOS E DISCUSSÃO}

O tratamento de esgoto sanitário da ETE Monjolinho é constituído por: tratamento preliminar (gradeamentos grosso e fino, desarenadores e reator para degradação de gorduras e óleos - estes retirados pelos escumadores dos desarenadores); tratamento biológico com reatores anaeróbios de fluxo ascendente (UASB); flotação por ar dissolvido para a remoção de sólidos suspensos gerados no processo biológico - precedido de floculação com coagulantes metálicos e polímeros (para a remoção de fósforo) (CAMPOS, 2013); desinfecção do efluente final com radiação ultravioleta (UV) e por pósaeração do esgoto tratado em escada hidráulica, antes que este seja lançado ao Rio Monjolinho.

Assim, analisando-se estas etapas, alguns aspectos ambientais foram observados e outros considerados de possível ocorrência, para os quais foram identificados potenciais impactos e elaborados indicadores ambientais. No Quadro 1 estão representados os aspectos, impactos e indicadores ambientais para os resíduos sólidos da ETEMonjolinho.

Quadro 1 - Instrumento de auxílio à identificação de aspectos e impactos ambientais e elaboração de indicadores ambientais para os resíduos sólidos da ETE-Monjolinho. A/P/S: Atividade, Produto ou Serviço.

\begin{tabular}{|c|c|c|c|}
\hline $\mathrm{A} / \mathrm{P} / \mathrm{S}$ & Aspectos ambientais & Impactos ambientais & Indicadores ambientais \\
\hline \multirow{4}{*}{  } & \multirow{2}{*}{$\begin{array}{l}\text { Exalação de odor } \\
\text { ruim (grades, esteiras } \\
\text { e caçambas) }\end{array}$} & $\begin{array}{l}\text { Incômodos aos trabalhadores e } \\
\text { população em geral }\end{array}$ & $\begin{array}{l}\mathrm{n}^{\circ} \text { de reclamações internas e } \\
\text { externas quanto a maus odores por } \\
\text { mês }\end{array}$ \\
\hline & & Atração de vetores de doenças & $\begin{array}{l}\mathrm{n}^{\circ} \text { de registros de grandes } \\
\text { quantidades de vetores de doenças } \\
\text { por mês }\end{array}$ \\
\hline & \multirow{2}{*}{$\begin{array}{l}\text { Geração de Rejeitos } \\
\text { sólidos }\end{array}$} & \multirow[t]{2}{*}{ Presença de patógenos } & $\begin{array}{l}\mathrm{n}^{\circ} \text { de profissionais com sintomas de } \\
\text { doenças transmitidas por patógenos } \\
\text { do esgoto bruto por mês }\end{array}$ \\
\hline & & & $\begin{array}{l}n^{\circ} \text { de registros da não utilização de } \\
\text { EPIs para os desarenadores por mês }\end{array}$ \\
\hline \multirow{5}{*}{$\begin{array}{l}0 \\
0 \\
0 \\
\frac{0}{0} \\
\text { D } \\
\frac{0}{0} \\
\frac{0}{0} \\
0 \\
0 \\
0\end{array}$} & $\begin{array}{ll}\text { Disposição } & \text { de } \\
\text { Rejeitos sólidos } & \\
\end{array}$ & Uso do solo & $\begin{array}{l}\text { \% de redução de rejeitos sólidos do } \\
\text { gradeamento por mês }\end{array}$ \\
\hline & \multirow{2}{*}{$\begin{array}{l}\text { Exalação de odor } \\
\text { ruim } \\
\text { (caçambas) }\end{array}$} & $\begin{array}{l}\text { Incômodos aos trabalhadores e } \\
\text { população em geral }\end{array}$ & $\begin{array}{l}\mathrm{n}^{\circ} \text { de reclamações internas e } \\
\text { externas quanto a maus odores por } \\
\text { mês }\end{array}$ \\
\hline & & Atração de vetores de doenças & $\begin{array}{l}\mathrm{n}^{\circ} \text { de registros de grandes } \\
\text { quantidades de vetores de doenças } \\
\text { por mês }\end{array}$ \\
\hline & \multirow{2}{*}{$\begin{array}{l}\text { Geração de Rejeitos } \\
\text { sólidos }\end{array}$} & \multirow[t]{2}{*}{ Presença de patógenos } & $\begin{array}{l}\mathrm{n}^{\circ} \text { de profissionais com sintomas de } \\
\text { doenças transmitidas por patógenos } \\
\text { do esgoto bruto por mês }\end{array}$ \\
\hline & & & $\begin{array}{l}n^{\circ} \text { de registros da não utilização de } \\
\text { EPIs para os desarenadores por mês }\end{array}$ \\
\hline \multirow{3}{*}{ 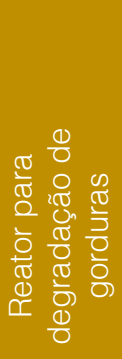 } & $\begin{array}{ll}\text { Disposição } & \text { de } \\
\text { Rejeitos sólidos } & \\
\end{array}$ & Uso do solo & $\begin{array}{l}\text { \% de redução de rejeitos sólidos dos } \\
\text { desarenadores por mês }\end{array}$ \\
\hline & \multirow[b]{2}{*}{$\begin{array}{l}\text { Geração de Resíduos } \\
\text { sólidos }\end{array}$} & Presença de patógenos & \multirow[b]{2}{*}{$\begin{array}{l}\mathrm{n}^{\circ} \text { de vazamentos de gorduras e } \\
\text { sólidos flutuantes por mês }\end{array}$} \\
\hline & & Poluição da água & \\
\hline
\end{tabular}


Quadro 1 - Instrumento de auxílio à identificação de aspectos e impactos ambientais e elaboração de indicadores ambientais para os resíduos sólidos da ETE-Monjolinho. A/P/S: Atividade, Produto ou Serviço. (continuação ...)

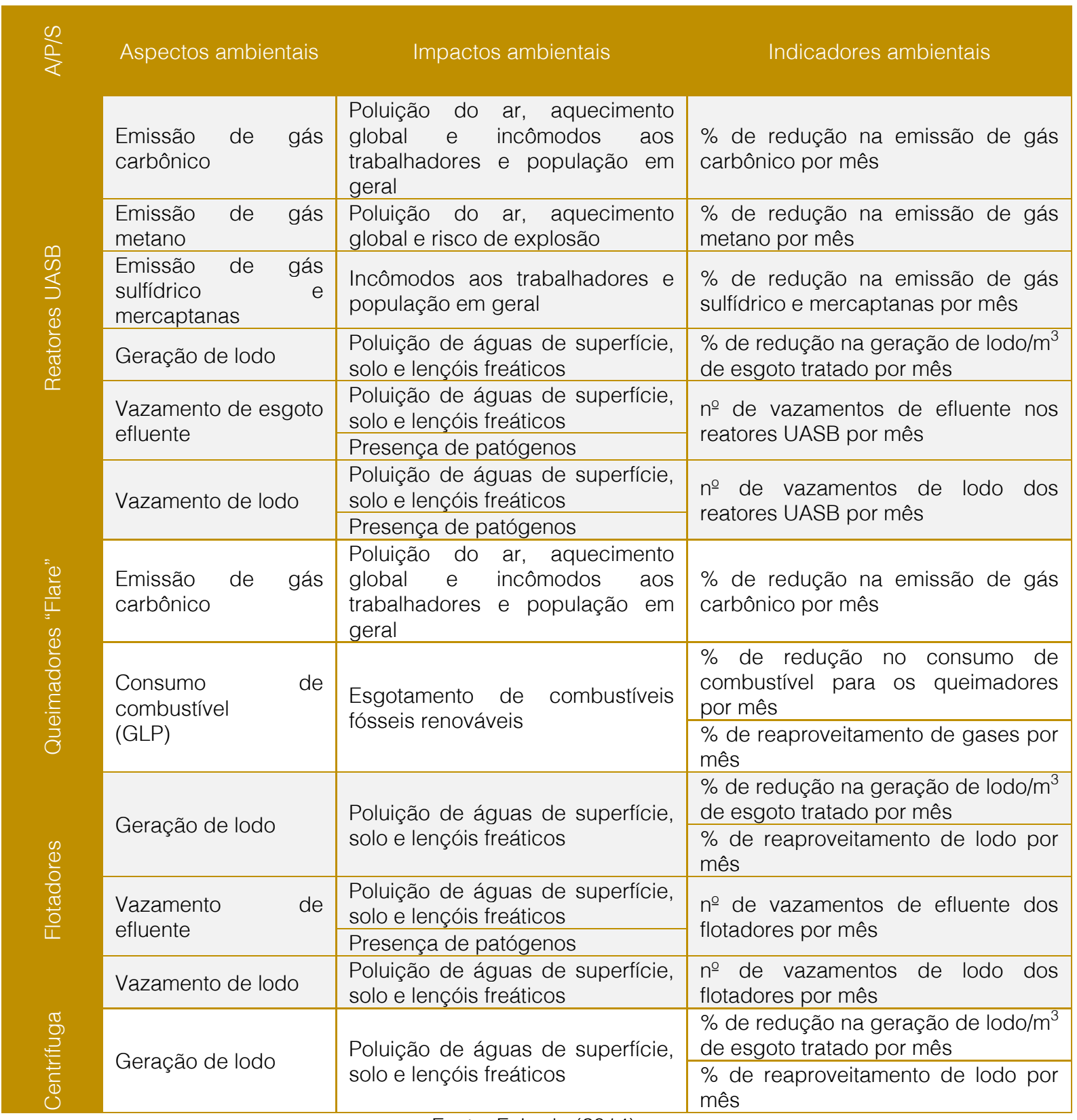

Fonte: Fajardo (2014).

No que se refere ao processo de desinfecção do efluente dos flotadores, não foi identificada a produção de resíduos sólidos. Os exemplos seguintes ilustram como os indicadores podem evidenciar o êxito, a estagnação ou dificuldades na implantação de um programa de gestão ambiental na ETE.

A elaboração de indicadores ambientais pode ser realizada na prática como no exemplo a seguir (indicador relativo à utilização de energia elétrica). Neste exemplo, seria possível verificar a diminuição ou aumento mensal no uso de energia elétrica para o tratamento do esgoto sanitário:

$\mathrm{I}_{\text {energia }}=\mathrm{kWh} / \mathrm{m}^{3}$ esgoto tratado no mês atual/ $\mathrm{kWh} / \mathrm{m}^{3}$ esgoto tratado no mês anterior $\times 100$

Em que $I_{\text {energia }}$ é o índice de energia elétrica utilizado para cada $\mathrm{m}^{3}$ de esgoto tratado.

Outro exemplo pode ser observado a partir da Figura 1. A redução das quantidades de areia e material gradeado removidos da ETEMonjolinho poderia significar, por exemplo, o êxito de programas de Educação Ambiental 
voltados à população para reduzir o teor de sólidos grosseiros no esgoto bruto ou mesmo para diminuir lançamentos de águas pluviais clandestinas na rede de esgoto sanitário em períodos de chuva.

Figura 1. Quantidades mensais (t) de areia e material gradeado removidos de janeiro a setembro de 2013 na ETE-Monjolinho, São Carlos-SP.

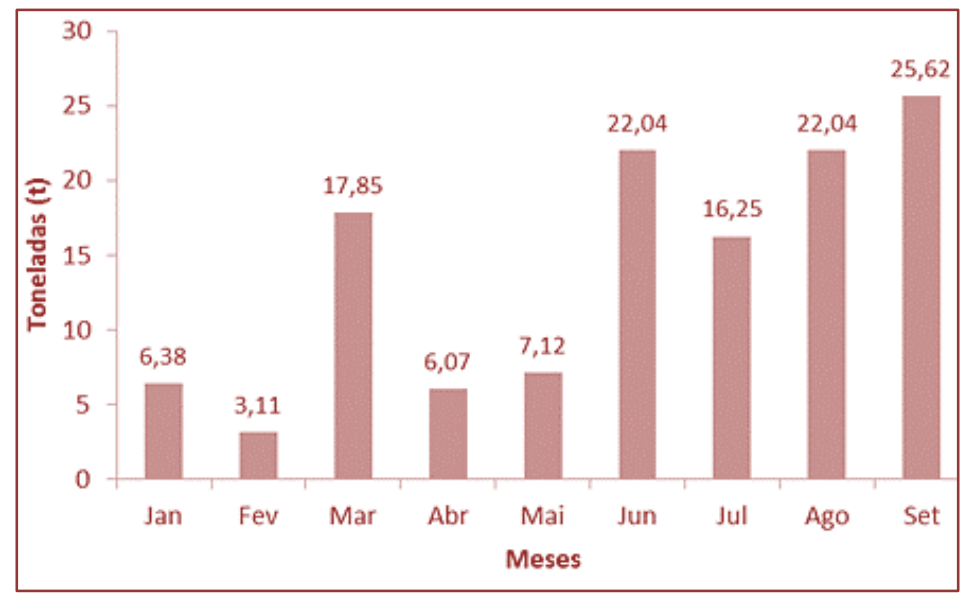

Fonte: Fajardo (2014).

Além disso, pelos dados da Figura 1, percebe-se que de junho a setembro de 2013, meses tipicamente de menor pluviosidade, ocorreram as maiores remoções de areia e material gradeado. Este fato sugere a necessidade, portanto, da realização de uma pesquisa mais aprofundada para verificar as causas do maior teor de sólidos nesse período.

\section{CONCLUSÕES}

Os resultados apresentados neste trabalho quanto aos resíduos da ETE-Monjolinho poderão contribuir para a utilização e aprimoramento de Planos de Gestão Ambiental de ETEs. Assim, planos de monitoramento e as medidas mitigadoras, compensatórias e de valorização dos impactos benéficos poderão ser melhor elaborados e direcionados.

Há também a possibilidade da elaboração de outros indicadores para os resíduos da ETEMonjolinho, além daqueles apresentados como exemplo neste trabalho. Além disso, normas como a NBR ISO 14001:2004, empregada para a implantação de Sistemas de Gestão Ambiental, podem ser utilizadas como facilitadores neste processo, já que possuem como objetivo principal evitar danos ambientais e utilizam-se de indicadores para a verificação de melhoria contínua.

Desta maneira, estudos de impacto ambiental poderão ser utilizados para além do processo de licenciamento, o que atenderia mais adequadamente aos anseios crescentes da sociedade por uma maior preservação e conservação ambientais.

\section{AGRADECIMENTOS}

Os autores agradecem à UFSCar, ao Departamento de Engenharia Civil (DECiv), ao Programa de Pós-Graduação em Engenharia Urbana (PPGEU), à Coordenação de Aperfeiçoamento de Pessoal de Nível Superior (CAPES), à Prefeitura Municipal de São Carlos-SP, ao Serviço Autônomo de Água e Esgoto (SAAE) de São Carlos-SP, e aos funcionários da ETE-Monjolinho, em São Carlos-SP. 


\section{REFERÊNCIAS}

[1] Associação Brasileira de Normas Técnicas. NBR ISO 14001: Sistemas de Gestão Ambiental - especificação e diretrizes para uso. Rio de Janeiro, 2004. 27 p.

$[2$

NBR ISO 14004: Sistemas de Gestão Ambiental Diretrizes gerais sobre princípios, sistemas e técnicas de apoio. 2004. Rio de Janeiro. 2004. 45p

[3] Brasil. Ministério do Meio Ambiente. Conselho Nacional do Meio Ambiente. Resolução no 001, de 23 de janeiro de 1986. Dispõe sobre os critérios básicos e diretrizes gerais para o Relatório de Impacto Ambiental. Diário Oficial [da] República Federativa do Brasil, Brasília, DF, 17 fev. 1986. Disponível

em:<file://C:/Users/User/Downloads/con00186. pdf>. Acesso em: 18 dez. 2014.

[4] Brasil. Ministério do Meio Ambiente. Conselho Nacional do Meio Ambiente. Resolução no 237, de 19 de dezembro de 1997. Regulamenta os aspectos de licenciamento ambiental estabelecidos na Política Nacional de Meio Ambiente. Diário Oficial [da] República Federativa do Brasil, Brasília, DF, 22 dez. 1997. Disponível
em:<file:///C:/Users/User/Downloads/con23797.pdf>. Acesso em: 18 dez. 2014

[5] Campos, J. R. Tratamento de esgoto no Brasil: cenários e inovações. In: BAGNATO, V. S.; Barrionuevo, W. (Coord.). Intercâmbio de inovações tecnológicas entre Brasil e Itália. São Carlos: Instituto de Física de São Carlos, USP, 2013. (No prelo)

[6] Fajardo, P. A.; Cordeiro, J. S. 2014. Instrumentos para avaliação ambiental inicial em estações de tratamento de esgotos sanitários como auxílio para a governança. In: 4ำ Congresso Internacional de Tecnologias para o Meio Ambiente, 2014, Bento Gonçalves-RS. Anais do evento. Disponível em: <http://vbaco01.ucs.br/congressoAnais2014/index. php/trabalhosTecnicos>. Acesso em: 6 dez. 2014.

[7] Fajardo, P. A. Proposta de instrumentos para a realização de Análise Ambiental Inicial em Etes à luz da NBR ISO 14001:2004: o caso da ETE Monjolinho, São Carlos-SP. 231 p. Dissertação. (Mestrado em Engenharia Urbana) Universidade Federal de São Carlos. São Carlos - SP, 2014.

[8] Sánchez, L. E. Avaliação de Impacto Ambiental: conceitos e métodos. 2. ed. São Paulo: Oficina de textos, 2013. 583 p 


\section{Gapítulo 19}

\section{AVALIACÃO DAS PERCEPCÕES, DOS VALORES E DAS DIFICULDADES DE UMA COLETA SELETIVA DE LIXO NO MUNICIPIO DE INHUMAS-GO}

João Baptista Chieppe Júnior

Gustavo Henrique Amaral Monteiro Rocha

Natasha Camilo da Silva Oliveira

Marcela Amorim da Silva

Resumo: Este projeto têm como objetivo avaliar dentro de um contexto atual como pensa e comporta os moradores da cidade de Inhumas-GO, caso fosse implantada a coleta seletiva de lixo, buscando conhecer seus hábitos, valores, atitudes e percepções no contexto desse processo. Utilizando técnicas de pesquisa com aplicação de questionários e entrevistas nos domicílios, tendo como base um questionário com perguntas estruturadas, essa avaliação serviu de base para o planejamento, inserção e viabilização de um novo programa de educação ambiental no município, identificando a melhoria que a coleta seletiva de lixo irá ter no processo de gestão de resíduos na cidade. Após conhecer a verdadeira situação do lixo no município buscando identificar o tipo de lixo produzido pela cidade, esse diagnóstico será apresentado a Prefeitura Municipal de Inhumas-GO, buscando implantar a construção de uma unidade de triagem e compostagem e paralelamente desenvolver um projeto de educação ambiental, que terá como objetivo sensibilizar a população para novos valores e atitudes em relação ao lixo.

Palavras-chave: coleta seletiva, lixo, educação ambiental. 


\section{INTRODUÇÃO}

O lixo é a vedete da maioria das experiências em educação ambiental, em escolas e empresas e, provavelmente em outros espaços. Paradoxalmente, muitos, talvez também a maioria, dos programas de coleta seletiva (em bairros, municípios, edifícios, instituições de natureza variada) prescindam de um programa consistente e permanente, ou consolidado, de educação ambiental. Sempre que esse tema vem a tona, vem à mente uma situação vivida há alguns anos: a regra dos $3 R$.

De acordo com Logarezzi (2006), o princípio que orienta ações de educação e gestão sobre o problema dos resíduos na grande maioria dos países do mundo, segundo o qual devemos adotar essencialmente três atitudes de modo integrado, procurando seguir determinadas prioridades: primeiro reduzir, depois reutilizar e reciclar Essa ordem coincide com a seqüência natural das atividades em que podem ser exercidas as atitudes, ou seja, reduzir: no consumo de produtos e serviços, incluindo durante o uso; reutilizar: após a geração e antes do descarte de resíduo; reciclar (do ponto de vista da(o) cidadã(o), que é, na verdade, apenas separar): no descarte; reciclar (do ponto de vista de agentes, como poder público, catadores e empresários): após o descarte. De fato essa priorização da redução apóia-se em sua capacidade de minimizar resíduo - e, consequentemente, também de minimizar lixo -, enquanto a reutilização e a reciclagem somente são capazes de minimizar lixo.

Os problemas decorrentes da geração de resíduo pelas atividades humanas do mundo atual são muitos, complexos e permanecem desafiando as sociedades em geral, especificamente no contexto urbano. A solução mais difundida é conhecida como coleta comum e associa o descarte comum dos resíduos sólidos domiciliares (convertidos, nesse ato, em lixo) à sua destinação para confinamento em aterro ou segregação em lixão, a céu aberto. As principais limitações para esse tipo de procedimento são: o desperdício de matériaprima, energia e outros insumos incorporados ao resíduos passíveis de reaproveitamento; os impactos ambientais negativos das células de deposição (lixões) ou de acondicionamento (aterros), poluindo o solo, as águas subterrâneas e o ar, além do alto custo estrutural e operacional e da dificuldade de serem, encontrados locais apropriados para essa destinação (Logarezzi, 2006).

Para Logarezzi (2006), a alternativa da coleta seletiva associa o descarte seletivo dos resíduos recicláveis secos e seu encaminhamento para a reciclagem, passando pela triagem e pelo acondicionamento. Nesse caso, há reaproveitamento de insumos incorporados e diminuição dos impactos ambientais negativos na coleta comum, na medida em que o resíduo da coleta seletiva deixa de compor o lixo da coleta comum, diminuindo o volume que chega aos aterros e lixões e assim, seus problemas, custos etc. Além disso, essa rota também gera oportunidade de trabalho e renda para populações excluídas do mercado de trabalho, o que é bastante significativo, especialmente em um país com um quadro social como o Brasil, que, entre outras coisas, costuma ser campeão mundial em desigualdade social. Incluem-se aqui as coletas formal e informal.

No entanto, a questão dos resíduos sólidos domiciliares permanece sem solução adequada, o que indica a necessidade de que tanto gestores(as) quanto educadores(as) revejam suas atuações nesse contexto. É preciso evoluir do tratamento que tem sido tradicionalmente adotado (coleta seletiva) como alternativa de solução em relação ao tratamento convencional (coleta comum). É preciso evoluir da noção do descarte seletivo para a de geração responsável de resíduo. E essa noção inclui $\mathrm{o} R$ da redução com a devida prioridade e requer que passemos a focar a etapa do consumo com espaço central das causas dos problemas e das possibilidades de solução. Sendo assim, quando se focaliza essa etapa, temos de reconhecer a complexidade da questão e, ao analisarmos algumas características da sociedade de consumo, somos incitados a considerar a tarefa que se apresenta no contexto das responsabilidades humanas, em suas três dimensões: "assumir as conseqüências diretas e indiretas de nossos atos; unir-se para sair da impotência; reconhecer que nossa responsabilidade é proporcional ao saber e ao poder de cada um "(PALMA, [s/d]). Essa noção de responsabilidade propõe novamente a associação entre ética e dever, numa era este final/início de século - descrita por Lipovetsky (1994, apud Portilho, 2005, p. 118) como do "pós-dever"ou da "pós-moralidade".

Nesse sentido, é especialmente significativo, por exemplo, o contexto da geração de 
resíduo e de sua destinação como lixo no Brasil, em que o drama social (de catadores em lixões, aterros e ruas) e a degradação ambiental (dos conhecidos impactos no solo, na água e no ar) devem ser compreendidos como implicações indiretas de nossos atos em sociedade, o que nos torna responsáveis por aqueles problemas e, na medida de nossa noção de cidadania, também pelas soluções que devem ser construídas ema ações individuais e coletivas (Locarezzi, 2006).

Segundo Rodrigues (1998, p.141), a produção de lixo é "[...] tão antiga quanto o processo de ocupação da terra pelo homem. Porém, alteram-se suas características (durabilidade e volume) no processo de desenvolvimento industrial".

À medida que nos dermos conta dessa alteração nas características do lixo, talvez ele passe a ser incorporado em nossas preocupações cotidianas em decorrência, principalmente, da falta de espaços para a disposição do lixo e da durabilidade dos materiais produzidos pela sociedade do descartável. Mesmo já estando incorporado às preocupações diárias de algumas pessoas, são poucas as que conseguiram desenvolver uma consciência crítica em relação aos processos de produção e consumo (Pitolli, 2006).

Colocadas as raízes da questão e seus principais impactos ambientais e possíveis estratégias de gestão e manejo dos resíduos, é preciso apontar para soluções que propõem minimizar esse montante.

Segundo Zacarias e Pinto (2006), a proposta de avaliar a gestão de resíduos, que tem como base um programa de educação ambiental, parece bastante interessante, pois sabe-se da ausência de dados que possam indicar como de fato a educação ambiental vem contribuindo para a melhoria dos problemas socioambientais. Sabe-se também que, por ser uma tarefa complexa, poucas instituições, principalmente as públicas, realizam esse tipo de avaliação de forma sistemática. A ausência desses processos pode levar, segundo Loureiro e Andrade (2001), à não-identificação de dificuldades, limitações ou erros que poderiam ser superados e percebidos a tempo.

Considerando que a gestão do município de Inhumas GO, não faz a coleta seletiva na área urbana, esse trabalho é justificável por oferecer informações básicas muito importantes que fazem parte da cadeia produtiva de reaproveitamento de resíduos urbanos, visto que os mesmos provocam sérios problemas sócio ambientais em decorrência da destinação inadequada.

Durante as últimas décadas, os resíduos sólidos produzidos pelo município estão sendo despejados às margens dos cursos d'água e em encostas da região, provocando sérios problemas socioambientais em decorrência da destinação inadequada.

Sendo assim, esse projeto têm como objetivo avaliar dentro de um contexto atual como pensa e comporta os moradores da cidade de Inhumas-GO, caso fosse implantada a coleta seletiva de lixo, buscando conhecer seus hábitos, valores, atitudes e percepções no contexto desse processo. Essa avaliação servirá de base para o planejamento, inserção e viabilização de uma novo programa de educação ambiental no município, identificando a melhoria que a coleta seletiva de lixo irá ter no processo de gestão de resíduos na cidade. Após conhecer a verdadeira situação do lixo no município buscando identificar o tipo de lixo produzido pela cidade, esse diagnóstico será apresentado a Prefeitura Municipal de Inhumas-GO, buscando implantar a construção de uma unidade de triagem e compostagem e paralelamente desenvolver um projeto de educação ambiental, que terá como objetivo sensibilizar a população para novos valores e atitudes em relação ao lixo.

\section{MATERIAL E MÉTODOS}

Entende-se que a avaliação da gestão de resíduos é uma forma regular de verificação de qualquer processo, que precisa ser visto como um projeto específico, com metodologia própria e etapas definidas. Com base nessas considerações, será estabelecida uma pesquisa, para compreender e avaliar como os moradores do Município de Inhumas-GO, participam da coleta seletiva de lixo (seus hábitos, atitudes e as dificuldades encontradas). Serão utilizadas técnicas de observação participativa, entrevistas semiestruturadas, bem como aplicação de um questionário.

Fases do desenvolvimento:

- Levantamento de dados para demarcar e separar por classe social o município de Inhumas- GO. 
- Aplicação dos questionários nos bairros de classe mediana (padrão de vida média/baixa) em primeiro momento, e posteriormente em bairros de padrão de vida alto. Os bairros participantes foram a Vila Jandira, Vila Floresta, Panorama Park, Setor Teodoro Alves, Vale das Goiabeiras e Centro.
- Tabulação dos dados adquiridos por meio do Microsoft Office Excel 2008.

- Estudo analítico dos dados tabulados.

Questionário usado para realização das pesquisas:

[Tabela 1] questionário domiciliar.

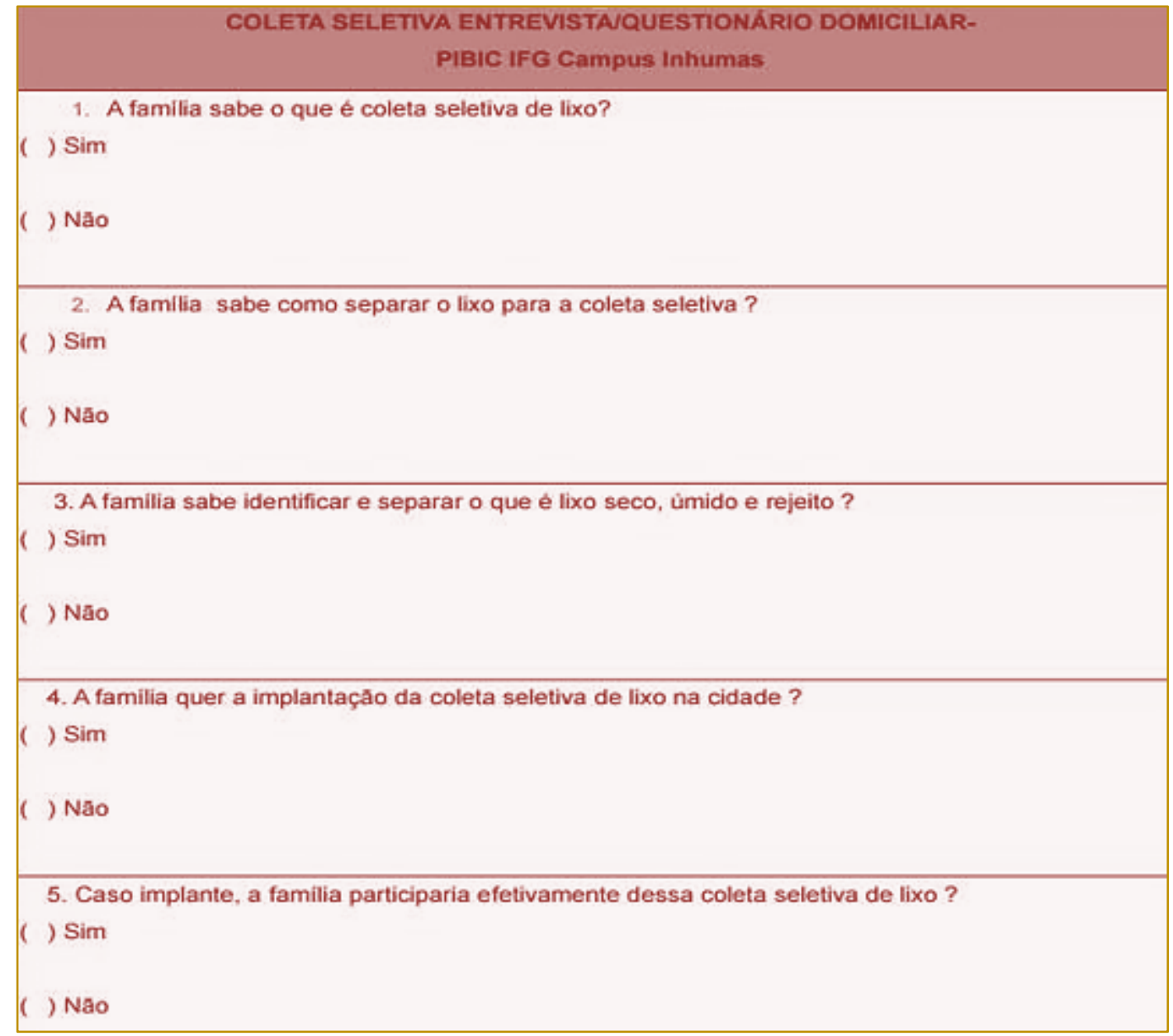

\section{RESULTADOS E DISCUSSÃO}

Os bairros estudados em uma análise descritiva para a realização da pesquisa domiciliar, foram analisados sobre a óptica dos padrões de vida de diferentes localidades de setores/vilas/bairros do município de Inhumas-GO, considerando que os indíviduos podem apresentar diferentes dificuldades, percepções e valores distintos, de acordo com sua relação com o meio, sendo a ausência destes processo como cita Loureiro e Andrade (2001), à não-identificação de dificuldades, limitações ou erros que poderiam ser superados e percebidos a tempo. O município foi analisado a partir de um mapa abaixo (MAPA 1) confeccionado em 2006 a partir das interpretações de informações do satélite LANDSAT 5TM. Os questionários foram aplicados de acordo com o padrão de vida dos moradores. 
[Mapa 1] Área Urbana Da Cidade De Inhumas/Go (2006)/Teixeira

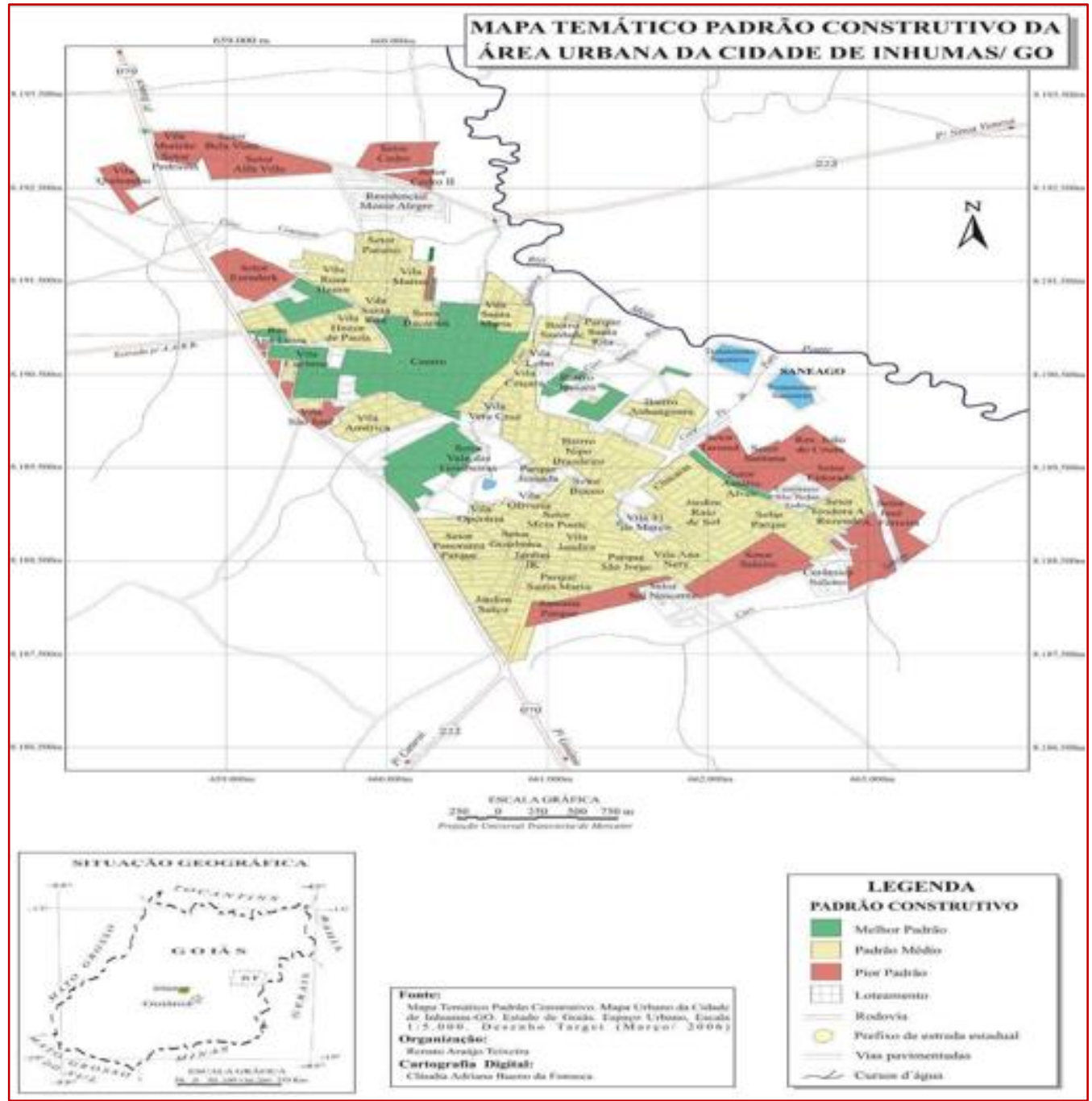

Os resultados das pesquisas realizadas em bairros brevemente selecionados e estratégicos, foram tabulados e analisados em forma de gráficos, em que foram realizadas entrevistas domiciliares em algumas casas de bairros, considerados de padrões medianos (padrão de vida média/baixa) em primeiro momento, e posteriormente em bairros de padrão de vida alto. Os bairros participantes foram a Vila Jandira, Vila Floresta, Panorama Park, Setor Teodoro Alves, Vale das Goiabeiras e Centro.

Nas entrevistas realizadas, categorizou-se que a recepção para realização das pesquisas/entrevistas em bairros de padrão de vida mediano possui maior receptividade por parte dos moradores do que em padrões de vida alto. Os dados isolados obtidos em cada padrão de bairros foram agrupados, tabulados e analisados em conjunto.

Obtivemos cinco gráficos, um para cada pergunta, com a porcentagem da amostragem total de entrevistados. As amostragens totais válidas foram de 300 casas. Os gráficos estão respectivamente, alinhados de acordo com a ordem da entrevista fechada realizada em domicílio. 
Gráfico 1 percentual da questão 1 - entrevista fechada domiciliar/ implementação da coleta seletiva em Inhumas-GO.

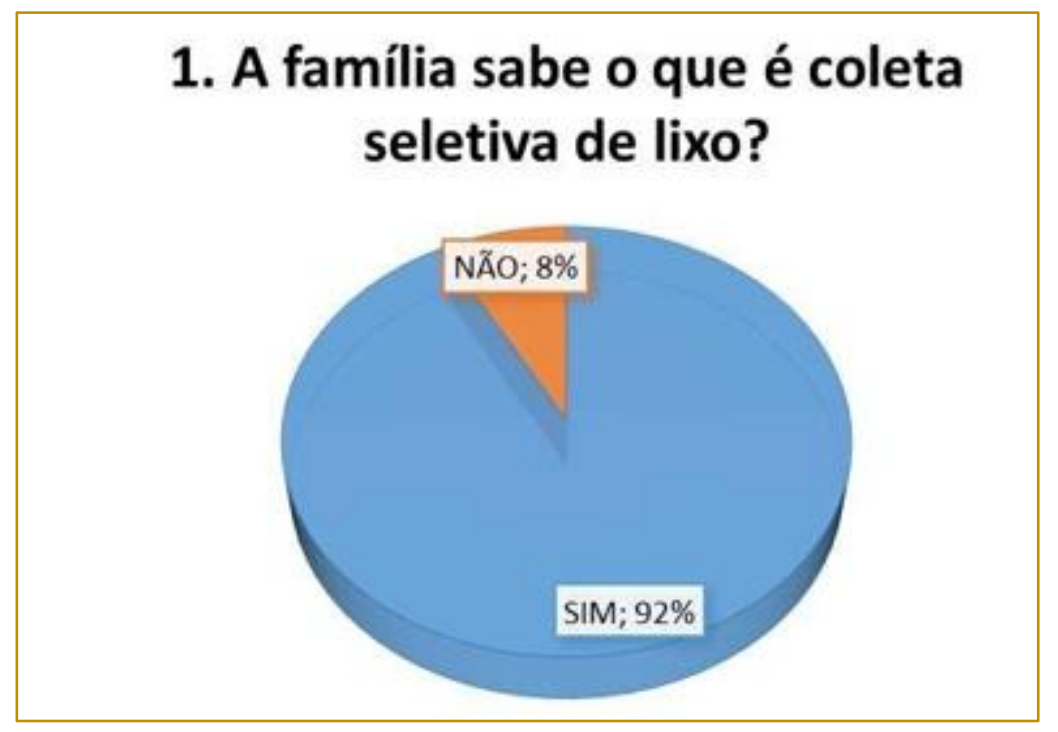

Gráfico 2 Percentual da Questão 2 - Entrevista Fechada Domiciliar/ Implementação da Coleta Seletiva em Inhumas-GO.

\section{A família sabe como separar o lixo para coleta seletiva?}




Gráfico 3 Percentual da Questão 3 - Entrevista Fechada Domiciliar/ Implementação da Coleta Seletiva em Inhumas-GO.

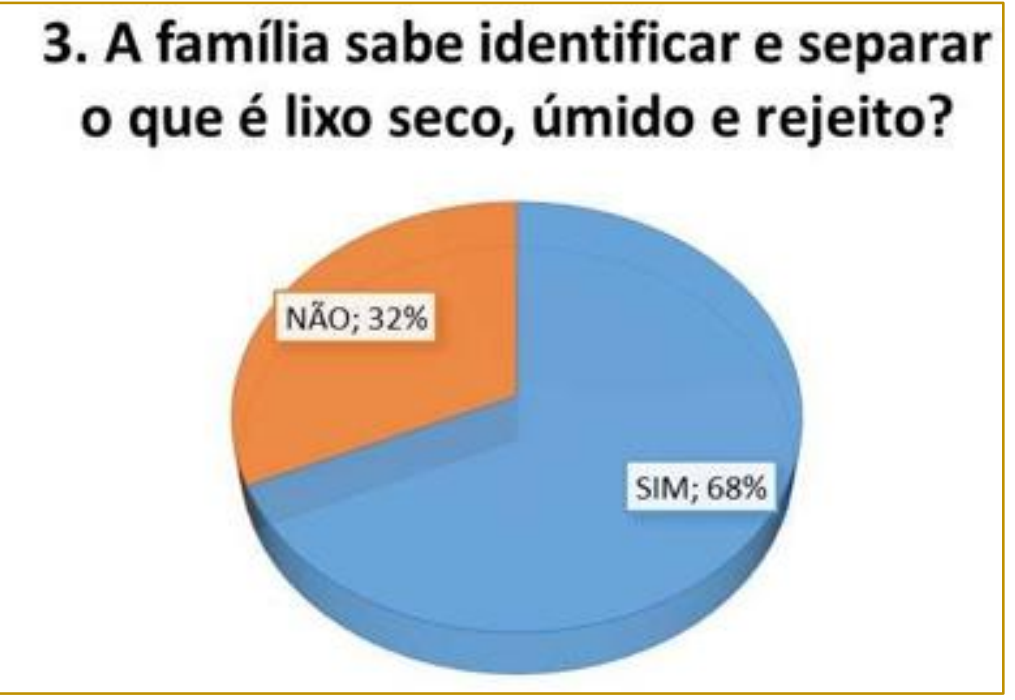

Gráfico 4 Percentual da Questão 4 - Entrevista Fechada Domiciliar/ Implementação da Coleta Seletiva em Inhumas-GO.

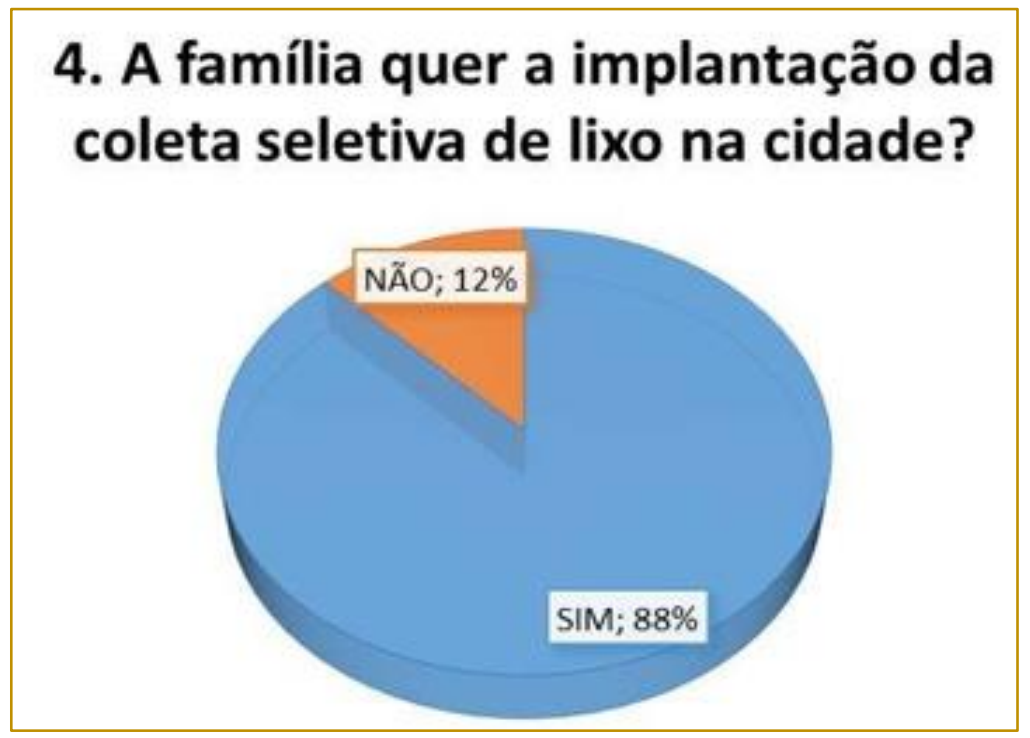


Gráfico 5 Percentual da Questão 5 - Entrevista Fechada Domiciliar/ Implementação da Coleta Seletiva em Inhumas-GO

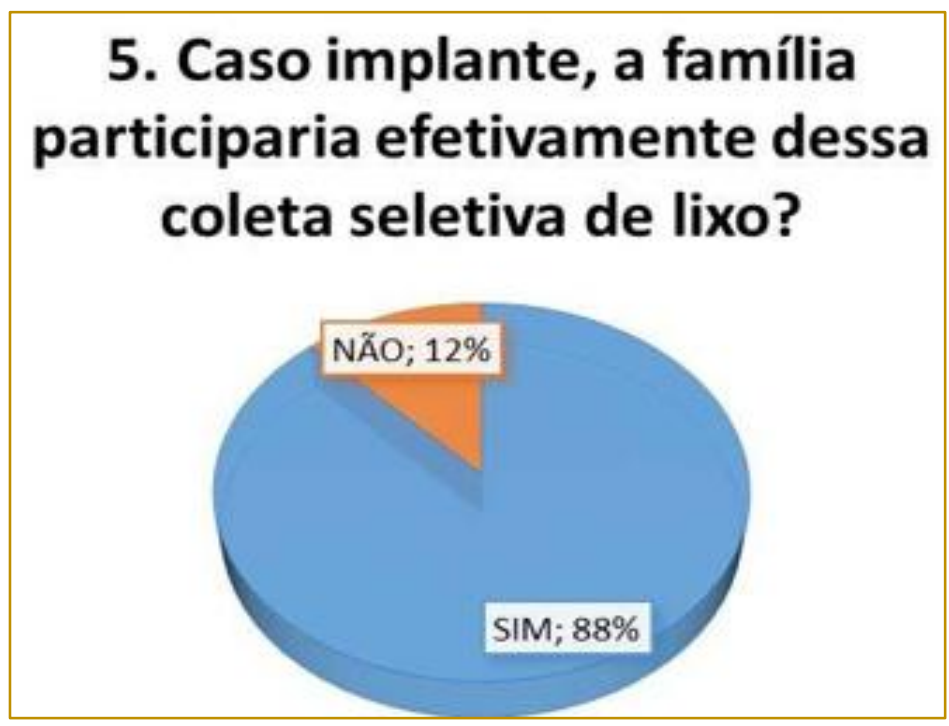

As análises mostraram que os indivíduos entrevistados do município de Inhumas-GO (92\%) conhecem o conceito de coleta seletiva de lixo. Todavia, da amostragem total (15\%) não sabem como separar o lixo para coleta seletiva; bem como (32\%) não sabem identificar e separar o que é lixo seco, lixo úmido e rejeito.

Em relação a implementação da coleta seletiva na cidade, entre os entrevistados, (88\%) desejam esta implementação e afirmaram que irão contribuir com a coleta seletiva caso fosse implantada na cidade. Todavia, a cidade não possui ainda um plano de gestão de resíduos para a coleta seletiva.

\section{CONCLUSÃO}

Conclui-se que a partir dos dados tabulados e analisados, grande maioria dos entrevistados da cidade de Inhumas-GO conhecem o conceito do sistema de coleta seletiva de lixo. No entanto, aproximadamente $1 / 3$ do

\section{REFERÊNCIAS}

[1] Locarezzi, A. Educação ambiental em resíduo: o foco da abordagem. In: Locarezzi, A. Cinquetti, H..C. S. (Orgs.) Consumo e Resíduo Fundamentos para o trabalho educativo. 1.ed.São Carlos: EdUFSCar, 2006. p. 119- 144.

[2] Loureiro, C. F. B.; Andrade, A. L. C. Monitoramento e avaliação de projetos em educação ambiental: uma contribuição para o desenvolvimento de estratégias. In: Santos, J. E. ; montante, tem dificuldades na separação dos lixos para este sistema de coleta. Sendo assim, pode-se aferir, a partir deste fator que a aceitação e a contribuição, caso a coleta seletiva fosse implantada, estão relacionados com o conhecimento de manuseio e organização no sistema de coleta seletiva na cidade.

Portanto, pontua-se ser necessário a sequência deste projeto, com a continuidade nos estudos das percepções e valores dos moradores locais, bem como, pensar na ótica de uma educação ambiental contribuindo para conhecimento da população leiga neste sistema altamente sustentável e benéfico para nossa sociedade. Além disso, é visto necessário a parceria com a prefeitura municipal para solução do problema de resíduos municipais, sendo importante sua atuação em campanhas de educação ambiental e estudo de caso para aplicação de um sistema de triagem e compostagem na região.

Sato, M. A. A contribuição da educação ambiental à esperança de Pandora. São Carlos: Rima, 2001.

[3] Palma, I. Carta das responsabilidades humanas: aliança para um mundo responsável, plural e solidário. São Paulo: Imagens Educação e Instituto Ágora em Defesa do eleitor e da Democracia, (s/d). Disponível em : http://alllies.alliance21org/chater>. 
[4] Pitolli, A.M.S. O lixo diário e os modos de (con)viver com ele. In: Locarezzi, A.; Cinquetti, $\mathrm{H}$. C.S. (Orgs.) Consumo e Resíduo - Fundamentos para o trabalho educativo. 1.ed.São Carlos: EdUFSCar, 2006. p.169-184.1998.

[5] Portilho, F. Sustentabilidade ambiental, consumo e cidadania. São Paulo: Cortez, 2005
[6] Rodrigues, A.M. Produção e consumo do e no espaço: problemática ambiental urbana. São Paulo: Hucitec,

[7] Zacarias, R.; Pinto, V.P.dos Santos.Reconhecendo as percepções, os valores e as dificuldades de Uma comunidade na coleta seletiva de lixo. In: Locarezzi, A.; Cinquetti, H. C. S. (Orgs.) Consumo 


\section{Gapítulo 20}

\section{LEVANTAMENTO DE ASPECTOS E IMPACTOS AMBIENTAIS APLICADO AOS ECOSSISTEMAS DE ILHAS E OCEÂNICOS}

\section{Tális Pereira Matias}

\section{Talita Vieira Maywald Prata}

\section{Adriana Maria Imperador}

Resumo: O crescimento populacional vinculado aos padrões insustentáveis de consumo causa diversos impactos aos ecossistemas, especialmente em zonas que apresentam maiores fragilidades ambientais, como as regiões costeiras e os ecossistemas de ilhas, que comumente são mais vulneráveis do que os ecossistemas continentais. Através da realização de um levantamento de aspectos e impactos ambientais (LAIA) podem-se obter informações para lidar com problemática ambiental e investir em técnicas de gestão e planejamento ambiental. Este trabalho foi realizado no norte da ilha de Florianópolis, durante 30 dias de análise, sendo 15 dias em alta temporada e 15 dias em baixa temporada, no ano de 2016. Os resultados são derivados desse trabalho de campo e também de uma revisão da literatura, e indicam intensa pressão antrópica na localidade estudada e danos aos ecossistemas costeiros, principalmente em função do esgoto e da disposição inadequada de resíduos sólidos.

Palavras-chave: Impactos ambientas; Poluição; Ecossistemas de ilhas. 


\section{INTRODUÇÃO}

Em função do seu isolamento geográfico as ilhas abrigam uma biodiversidade muito peculiar, em sua maioria composta com espécies endêmicas e vulneráveis à pressão das atividades antrópicas, como poluição e outros impactos ambientais, o que frisa a importância da realização de estudos para a tomada de decisão pelos órgãos competentes visando o desenvolvimento sustentável (CÓZAR et al., 2014; SERAFINI, 2010).

Inseridos nesta problemática, tem-se sérios problemas de perda de biodiversidade, alterações de nichos ecológicos, danos ambientais de difícil mensuração, além de prejuízos à saúde humana e comprometimento dos corpos d' água, como rios, lagos, lagunas, córregos e oceanos (TOMAZELA, 2008).

As regiões litorâneas e de ilhas são áreas extremamente vulneráveis à poluição, pois embora os ambientes oceânicos apresentem altas taxas de aeração, eles também abrigam uma biodiversidade vulnerável à poluição, especialmente pelos resíduos sólidos, que entram nas cadeias alimentares prejudicando os indivíduos que compõe a biodiversidade marinha, além dos organismos presentes na linha de costa que são potencialmente afetados pelo mesmo problema (MAZZER, 2007).

O turismo, a pesca e as atividades comerciais também são atingidas pela falta de um gerenciamento de resíduos sólidos eficaz, que geram problemas de magnitude local e externalidades, podendo ser externalidades globais, uma vez que os resíduos sólidos no mar podem atingir longas distâncias propagando o dano ambiental (OLIVEIRA, 2015).

O levantamento de aspectos e impactos ambientais (LAIA) é uma ferramenta da gestão ambiental que através de procedimentos específicos pode servir como base para a definição de objetivos e metas para lidar com os aspectos e impactos ambientais detectados. É uma técnica de análise que exige percepção ambiental e análise crítica, e é um importante recurso preliminar de análise para a execução de projetos de engenharia ambiental, podendo ser utilizado em ecossistemas de ilhas e diversos ambientes ou empreendimentos (CRUZ; ARAÚJO, 2015; FREIRE; LOPES; SÁ, 2016; GOMES et al., 2015).
A ilha de Florianópolis/ SC (Brasil) é uma das três capitais insulares do Brasil, e vem cada vez mais se tornando uma importante cidade turística, e associado ao turismo intenso surgem impactos ambientais que devem ser observados visando a conservação ambiental. Segundo o IBGE, em 1996 a ilha apresentava 268.551 habitantes, já em 2010, chegou a 421.240 habitantes, esse crescimento tende a aumentar e com ele os impactos ambientais (PMF, 2016).

Embora a ilha de Florianópolis apresente um número razoável de reservas legais e projetos que visam melhorias nos aspectos ambientais da região, a questão do saneamento básico ainda é muito deficiente nesta região, sendo necessária a realização de estudos técnicos que possam servir de base para a tomada de decisão e reformulações do sistema de gerenciamento dos resíduos sólidos locais (TOMAZELA, 2008).

O objetivo desse trabalho foi a realização de um LAIA e a sugestão de medidas mitigatórias e ações preventivas para os impactos ambientais levantados na região norte da ilha de Florianópolis, na praia de Canasvieiras, a fim de gerar informações que possam ser utilizadas pelo poder público na tomada de decisão, além de realizar uma abordagem sobre os impactos ambientais e as suas externalidades a fim de justificar a importância de um gerenciamento ambiental eficiente na área estudada.

\section{METODOLOGIA}

\subsection{CARACTERIZAÇÃO DA ÁREA DE ESTUDO}

O local escolhido para a realização deste trabalho de campo foi a ilha de Florianópolis, devido a sua vulnerabilidade ambiental perante a pressão antrópica, cada vez mais acentuada na região, além de ser um ponto estratégico para o estudo da propagação de resíduos no oceano, em função do seu posicionamento geográfico.

A cidade de Florianópolis é a capital do estado de Santa Catarina (Figura1). Situa-se no litoral catarinense, possui uma área de $671,58 \mathrm{~km} 2$ e conta com uma parte insular e outra parte continental, que foi incorporada à cidade em 1927, através da ponte pênsil Hercílio Luz, Colombo Salles e Pedro Ivo Campos. O clima predominante é o subtropical úmido, alternando entre verões e 
invernos, e abundante distribuição anual de chuvas (BRASIL, 2010 ; PMF, 2016).

As unidades geomorfológicas da capital correspondem às Serras Cristalinas Litorâneas, estas são formadas por conjuntos montanhosos denominados de Maciços Graníticos e as Planícies Litorâneas que representam as terras baixas de Florianópolis, na qual são formadas por processos marinhos e continentais de acumulação e erosão (DIEDERICHSEN et al., 2013).

Segundo o mesmo autor, no aspecto fitogeográfico em Florianópolis são encontradas áreas de densa vegetação típica de mata atlântica, presentes em sua maioria sobre os topos e as vertentes de morros.

Figura 1. Localização da cidade de Florianópolis em Santa Catarina.

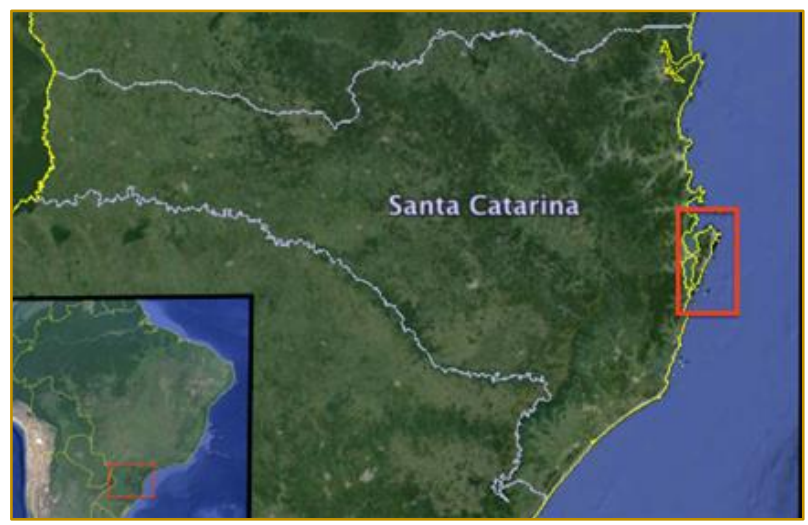

Fonte: Google Earth Pro (acesso em 08. Jun. 2016).

Florianópolis é uma das três capitais insulares do Brasil e vem cada vez mais se tornando um centro turístico, devido principalmente à beleza das praias que circulam a ilha (Jurerê, Canasvieiras, Ingleses, Armação e outras). Porém, torna-se cada vez mais preocupante o conflito existente entre o crescimento populacional e a destinação final dos resíduos, portanto um aspecto que deve ser levado em consideração é a demografia. Segundo o IBGE, em 1996 a ilha apresentava 268.551 habitantes, já em 2010, chegou a 421.240 habitantes (BRASIL, 2010; PMF, 2016).

Devido ao contexto de urbanização da área litorânea e grande atratividade turística, como é o caso de Florianópolis, é de suma importância o estudo dos resíduos sólidos, efluentes líquidos e outros impactos ambientais. A ocupação de forma negligenciada pelo planejamento urbano causa uma redução do ambiente natural, gerando um desequilíbrio ambiental e ameaçando as espécies que dependem do ambiente litorâneo para sobreviver (ELLER et al., 2013).

\subsection{PROCEDIMENTO E TÉCNICAS ADOTADAS}

A metodologia de análise dos trabalhos de campo consistiu na percepção ambiental dos autores perante os aspectos e impactos ambientais observados durante a pesquisa, os materiais utilizados foram notebook, GPS Portátil Garmim eTrex, câmera fotográfica e planilhas eletrônicas. Os trabalhos de campo foram estruturados da seguinte forma:

- $\quad$ Análises em baixa temporada: Realizada no mês de julho de 2016, inclui visita técnica e registro das condições ambientais locais sob reduzida pressão antrópica, uma vez que no inverso a quantidade de turistas é menor.

- $\quad$ Análises em alta temporada: Realizada no mês de dezembro de 2016, inclui visita técnica e registro das condições ambientais sob alta pressão antrópica.

Os estudos incluem 15 dias de análises em cada temporada, com visitas técnicas diárias na região costeira da pesquisa. Durante este período foram observados e avaliados os principais impactos ambientais e pressões sofridas no ambiente natural decorrente das atividades antrópicas na região, totalizando assim, 30 dias de estudos de campo e visitas técnicas para a obtenção de dados e informações.

A fim de coletar informações sobre a fauna aquática afetada por impactos ambientais associados às atividades antrópicas na região, foi feita uma visita técnica ao projeto TAMAR situado na Rua Professor Ademir Francisco s/n, Barra da Lagoa. 


\subsubsection{PROCEDIMENTO DO LAIA}

O procedimento utilizado para a construção do LAIA consiste na observação da frequência de ocorrência dos aspectos e impactos ambientais em baixa e alta temporada, tendo uma pontuação de 1 a 3 , sendo a maior pontuação correspondente a maior frequência de ocorrência dos aspectos e impactos ambientais levantados.

Para a determinação do grau de risco o impacto ambiental apresenta maior significância perante o aspecto ambiental, isto é, o aspecto ambiental pode não ter sofrido alterações durante as duas temporadas, mas se houve percepção de maior impacto ambiental, este implicará em uma atribuição de maior grau de risco. Por exemplo, na diferença entre duas temporadas estudadas, determinado tipo de resíduo sólido é encontrado disposto em quantidades semelhantes, porém se houver evento de precipitação em uma das temporadas, o impacto ambiental será maior devido ao entupimento de bueiros em função dos resíduos, embora o aspecto ambiental não tenha mudado (quantidade de resíduo), assim o grau de impacto ambiental terá um peso maior, embora o aspecto em si não tenha sofrido uma variação quantitativa, pois o que variou foi o regime de chuvas.
Desta forma pode-se construir um LAIA básico que atue como guia de orientação para a tomada de decisão de ações de gestão ambiental, levando em consideração os principais aspectos e impactos ambientais detectados.

Além do procedimento de construção do LAIA o presente trabalho também é produto de uma revisão bibliográfica que permitiu uma discussão mais articulada entre os elementos levantados em campo e o seu contexto global, realizando uma abordagem sobre os impactos ambientais nos ecossistemas de ilhas e ambientes oceânicos.

\section{RESULTADOS E DISCUSSÃO}

\subsection{LEVANTAMENTO DE ASPECTOS E IMPACTOS AMBIENTAIS (LAIA)}

Os resultados da pesquisa encontram-se representados na Tabela 1, que correspondem ao LAIA gerado durante a realização dos trabalhos de campo. Os aspectos ambientais são detalhados e correlacionados aos seus respectivos impactos ambientais nos itens de 1 a 10 subsequentes.

Tabela 1. Levantamento de aspectos e impactos ambientais (LAIA) na região costeira de Canasvieiras e Centrinho (Florianópolis - SC).

\begin{tabular}{|c|c|c|c|c|c|c|c|c|}
\hline & & & & LAIA & & & & \\
\hline $\begin{array}{c}\text { Aspectos } \\
\text { Ambientais }\end{array}$ & $\begin{array}{l}\text { Principais } \\
\text { Impactos } \\
\text { Ambientais }\end{array}$ & F.a.b. & F.a.a. & F. i. b. & F. i. a. & R.b & R.a & $\begin{array}{c}\text { Medidas Mitigatórias } \\
\text { e Preventivas } \\
\text { Aplicáveis }\end{array}$ \\
\hline $\begin{array}{l}\text { 1.Embalagens } \\
\text { Plásticas de } \\
\text { Produtos }\end{array}$ & $\begin{array}{l}\text { Enchentes, } \\
\text { poluição visual, } \\
\text { e danos à } \\
\text { biodiversidade }\end{array}$ & 2 & 3 & 2 & 3 & Médio & Alto & $\begin{array}{l}\text { Reduzir, Reutilizar, } \\
\text { Reciclar; Educação }\end{array}$ \\
\hline $\begin{array}{l}\text { 2.Papéis } \\
\text { provenientes do } \\
\text { comércio local }\end{array}$ & $\begin{array}{l}\text { Enchentes, } \\
\text { poluição visual, } \\
\text { e danos à } \\
\text { biodiversidade }\end{array}$ & 2 & 3 & 2 & 3 & Médio & Alto & $\begin{array}{l}\text { Ambiental; } \\
\text { Monitoramento e } \\
\text { controle; Destinação } \\
\text { final adequada; }\end{array}$ \\
\hline $\begin{array}{l}\text { 3.Vidros e } \\
\text { metais de } \\
\text { origem } \\
\text { comercial e não } \\
\text { comercial }\end{array}$ & $\begin{array}{l}\text { Cortes } \\
\text { ferimentos, } \\
\text { poluição visual, } \\
\text { marinha } \\
\text { costeira }\end{array}$ & 1 & 3 & 1 & 3 & Baixo & Alto & $\begin{array}{l}\text { Planos de } \\
\text { gerenciamento dos } \\
\text { resíduos sólidos } \\
\text { aplicados }\end{array}$ \\
\hline $\begin{array}{l}\text { 4.Esgoto } \\
\text { doméstico }\end{array}$ & $\begin{array}{l}\text { Poluição } \\
\text { marinha, } \\
\text { contaminação, } \\
\text { danos à saúde } \\
\text { e à } \\
\text { biodiversidade }\end{array}$ & 2 & 3 & 3 & 3 & Alto & Alto & $\begin{array}{l}\text { Tratamento de } \\
\text { efluentes; } \\
\text { Monitoramento } \\
\text { constante; } \\
\text { Disponibilização de } \\
\text { informações }\end{array}$ \\
\hline
\end{tabular}


Tabela 1. Levantamento de aspectos e impactos ambientais (LAIA) na região costeira de Canasvieiras e Centrinho (Florianópolis - SC) (continuação ...)

\begin{tabular}{|c|c|c|c|c|c|c|c|c|}
\hline & & & & LAIA & & & & \\
\hline $\begin{array}{l}\text { Aspectos } \\
\text { Ambientais }\end{array}$ & $\begin{array}{l}\text { Principais } \\
\text { Impactos } \\
\text { Ambientais }\end{array}$ & F.a.b. & F.a.a. & F. i. b. & F. i. a. & R.b & R.a & $\begin{array}{c}\text { Medidas Mitigatórias } \\
\text { e Preventivas } \\
\text { Aplicáveis }\end{array}$ \\
\hline $\begin{array}{l}\text { 5.Animais } \\
\text { domésticos na } \\
\text { praia }\end{array}$ & $\begin{array}{l}\text { Propagação de } \\
\text { doenças } \\
\text { resíduos } \\
\text { orgânicos no } \\
\text { mar (potencial) } \\
\end{array}$ & 1 & 1 & 1 & 1 & Baixo & Baixo & $\begin{array}{l}\text { Educação Ambiental; } \\
\text { Programas } \\
\text { específicos de gestão }\end{array}$ \\
\hline $\begin{array}{l}\text { 6.Drenagem } \\
\text { Urbana }\end{array}$ & $\begin{array}{l}\text { Enchentes, } \\
\text { água parada, } \\
\text { presença de } \\
\text { vetores }\end{array}$ & 1 & 2 & 2 & 3 & Médio & Alto & $\begin{array}{l}\text { Projetos de } \\
\text { engenharia } \\
\text { (Declividade, canais, } \\
\text { bocas de lobos, etc.) }\end{array}$ \\
\hline $\begin{array}{l}\text { 7.Restos de } \\
\text { alimentos: } \\
\text { Resíduos } \\
\text { orgânicos }\end{array}$ & $\begin{array}{l}\text { Contaminação, } \\
\text { odor, ambiente } \\
\text { favorável para } \\
\text { proliferação de } \\
\text { vetores }\end{array}$ & 1 & 2 & 1 & 1 & Baixo & Baixo & $\begin{array}{l}\text { Compostagem; } \\
\text { Educação Ambiental }\end{array}$ \\
\hline $\begin{array}{l}\text { 8. Lixeiras } \\
\text { inadequadas à } \\
\text { demanda }\end{array}$ & $\begin{array}{l}\text { Transbordo de } \\
\text { resíduos } \\
\text { sólidos, } \\
\text { infiltração de } \\
\text { líquidos }\end{array}$ & 3 & 3 & 2 & 3 & Médio & Alto & $\begin{array}{l}\text { Aumentar a } \\
\text { quantidade de } \\
\text { lixeiras; Aumentar as } \\
\text { entradas das lixeiras; } \\
\text { Impermeabilizar as } \\
\text { bases }\end{array}$ \\
\hline $\begin{array}{l}\text { 9.Árvores } \\
\text { impróprias }\end{array}$ & $\begin{array}{lr}\text { Excesso de } \\
\text { folhas grandes } \\
\text { nas ruas e } \\
\text { bocas r de } \\
\text { lobos, quebra } \\
\text { das calçadas }\end{array}$ & 1 & 1 & 1 & 1 & Baixo & Baixo & $\begin{array}{l}\text { Realizar a troca de } \\
\text { espécies } \\
\text { inadequadas ao } \\
\text { ambiente urbano por } \\
\text { espécies apropriadas }\end{array}$ \\
\hline 10.Veículos & $\begin{array}{l}\text { Poluição } \\
\text { atmosférica } \\
\left(\mathrm{NOx}, \mathrm{CO}, \mathrm{CO}_{2}\right)\end{array}$ & 2 & 3 & 1 & 2 & Baixo & Médio & $\begin{array}{l}\text { Uso de transporte } \\
\text { coletivo, boas } \\
\text { condições de filtro } \\
\text { dos veículos, } \\
\text { favorecer a dispersão } \\
\text { de poluentes }\end{array}$ \\
\hline & & & & genda & & & & \\
\hline F.a.b & Frequência dos & specto & ambie & tais em & oaixa te & nporada & & \\
\hline F.a.a & Frequência dos & specto & ambie & tais em & alta tem & orada & & \\
\hline F.i.b & Frequência dos i & mpacto & ambie & tais em & oaixa te & iporada & & \\
\hline F.i.a & Frequência dos i & mpacto & ambie & tais em & alta tem & orada & & \\
\hline R.b & Grau de risco de & ocorrêr & cia do & npacto & mbient & em baì & a temp & rada \\
\hline R.a & Grau de risco de & ocorrêr & cia do & npacto & mbient & em alta & empo & \\
\hline
\end{tabular}

\section{EMBALAGENS PLÁSTICAS DE PRODUTOS}

Foi observado na localidade abundância de resíduos plásticos dispostos nas calçadas, derivados do comércio local, em condições suscetíveis ao transporte pelo vento ou chuva até o mar, podendo entupir bocas de lobo diminuindo a eficiência da rede de drenagem local e assim ocasionando enchentes. Em alta temporada, no período chuvoso, foram observados eventos de precipitação em que pequenas enchentes ocorreram, e os resíduos plásticos além de afetar a drenagem ainda foram transportados para o mar onde podem prejudicar os ecossistemas locais, como problemas gastrointestinais nas espécies que podem vir a se alimentar deste material confundindo-os com os seus alimentos naturais, como é o caso das tartarugas marinhas.

No período de verão aumentam a quantidade de materiais de maior mobilidade, como sacolas, copos, canudos e garrafas plásticas. Tais materiais são depositados normalmente na maré vazante, demonstrando serem materiais de fontes distantes ou em outros casos, lixos deixados pelos banhistas. 
Ao analisar as possíveis fontes dos resíduos e investigar a sua dinâmica na praia, percebe-se a influência das diferentes estações do ano (verão e inverno), nos meses de verão, com o uso mais intenso da praia por banhistas, aumentou a proporção de copos e canudos plásticos, sendo que neste caso a principal fonte de tais resíduos são os turistas e banhistas.

\section{PAPÉIS PROVENIENTES DO COMÉRCIO LOCAL}

O resíduo sólido mais abundante na região, depois do plástico, é o papel, que pode ser transportado para o oceano causando impactos a biodiversidade local, ou ainda sendo propagado para regiões mais distantes pelas correntes marinhas, assim como outros resíduos sólidos.

Este material tem origem comercial, doméstica e turística, podendo variar desde papéis limpos e secos, até mesmo papéis contaminados como guardanapos usados, papel higiênico, lenços de papel e outros.

\section{VIDROS E METAIS DE ORIGEM COMERCIAL E NÃO COMERCIAL}

Esses materiais são mais significativos em alta temporada, estando associados a intensa atividade turística na região, os principais materiais encontrados foram latinhas de refrigerante e cerveja, espalhados pelas ruas e na areia da praia, podendo não só afetar os organismos aquáticos como também apresentam a possibilidade de ferimentos aos turistas e moradores por fragmentos de vidros e metais na areia.

\section{ESGOTO DOMÉSTICO}

A questão do esgoto doméstico é um elemento que preocupa moradores e turistas pois pode gerar problemas à saúde dos banhistas. Foram observados 5 pontos em que havia fluxo de água para o mar, esta água apresentava coloração escura, odor, espumas e óleos, que são indicadores de má qualidade da água. 0 ponto mais crítico de poluição foi detectado no começo da praia, nas coordenadas 27-35'34.34" S e 4826'57.36" O, $5 \mathrm{~m}$ de elevação, perto do trapiche, no qual existe uma barricada de areia para conter o esgoto vindo do Rio do Brás (Figura 2 e 3), porém quando acontece uma chuva de maior intensidade, a barricada é insuficiente para conter o vazamento do esgoto, que extravasa e chega ao mar. Outro indicador de possível contaminação e poluição das águas foi a mortandade de peixes. Em aproximadamente $1,5 \mathrm{~km}$ de percurso na orla da praia de Canasvieiras foram contabilizados 25 peixes mortos, além de espumas e materiais graxos na água.

Figura 2. Poluição da água e da areia por efluentes líquidos domésticos.

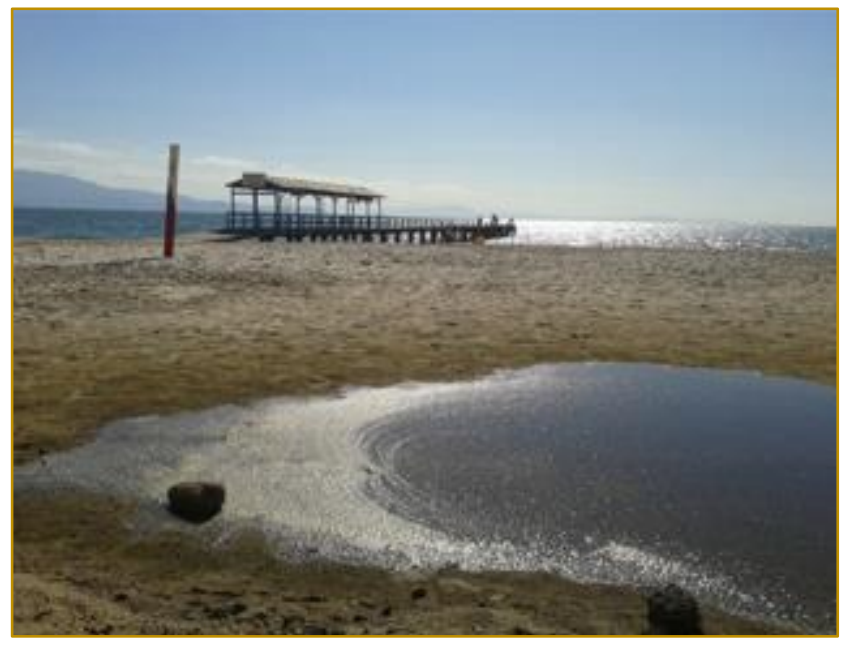


Figura 3. Barreira de areia que separa o rio poluído do mar.



Neste ponto crítico apenas uma curta barreira de areia separa a água poluída do mar, sabe-se a areia pode contribuir como filtro natural para a contenção de sólidos mais grosseiros, todavia um sistema sobrecarregado perde eficiência, necessitando de limpeza, o que visivelmente não ocorre na localidade.

Além da área crítica do Trapiche, em outras regiões foi observado que há presença de água com qualidade visivelmente ruim, e animais como garças e outros tipos de aves ali presentes, podendo gerar diversos tipos de danos à saúde desses animais e também dos seres humanos que ali possam interagir com contaminantes.

\section{ANIMAIS DOMÉSTICOS NA PRAIA}

Embora apresente baixa frequência de ocorrência, foram observados animais domésticos na praia, como algumas raças de cães, estes animais além de poder defecar na areia e gerar riscos de contaminação, também podem ser contaminados pela poluição do Rio do Brás, uma vez que o acesso ao rio é fácil, todavia este aspecto ambiental foi pouco observado em campo.

\section{DRENAGEM URBANA}

Durante os 15 dias consecutivos de análise na primeira temporada, durante todos os dias foi observado o acúmulo de água em algumas ruas, em área plana e na ausência de chuva no período, o que indica uma possível falha no sistema de drenagem, gerando riscos de vetores que se estabelecem em águas paradas. $\mathrm{Na}$ segunda temporada essa observação torna- se irrelevante, uma vez que houveram eventos de precipitação acentuados e a região encontrava-se com alagações que variavam bastante diariamente. Em alguns casos também se pode observar a presença de árvores inadequadas à localidade, justificado pelas suas raízes que danificavam as calçadas e as suas folhas que entupiam bocas de lobo, aumentando as chances de enchentes, assim como o volume de lixo nas ruas, especialmente em altas temporadas.

\section{RESTOS DE ALIMENTOS: RESÍDUOS ORGÂNICOS}

Quanto aos resíduos orgânicos associados aos alimentos produzidos ou consumidos na região, em alta temporada há um aumento observado em lixeiras e nas ruas, sendo, todavia, estes resíduos pouco relevantes em função de sua baixa abundância no local.

\section{LIXEIRAS INADEQUADAS A DEMANDA}

A quantidade de lixeiras ao longo da orla e no centrinho (região comercial da praia), pequena e incapaz de suprir a demanda, até mesmo em baixa temporada essas lixeiras apresentam baixa eficácia, sendo que muitos volumes de resíduos comerciais, principalmente plásticos, papéis e papelões, ficam dispostos nas ruas amarrados em postes e fora das lixeiras, ficando vulneráveis à dispersão pelo vento e pela água da chuva. Outro fator observado refere-se ao tamanho das lixeiras e das suas aberturas, que são muito pequenas. Entretanto o tamanho e a quantidade das lixeiras não é o único elemento problemático nesse assunto. As lixeiras 
presentes na orla, além de apresentarem estes aspectos problemáticos, ainda não dispõem de base impermeável, ou seja, existe o risco de infiltração de resíduos líquidos no solo e contaminação da areia e do mar, podendo também haver transporte de resíduos sólidos de dentro das lixeiras para fora quando a maré está alta, uma vez que em vários pontos foram detectadas lixeiras soterradas, facilmente atingidas pela elevação da maré.

Outra circunstância a ser destacada é que durante a baixa temporada a quantidade de resíduos é menor, o que reduz o impacto ambiental associado ao tamanho e quantidade das lixeiras, entretanto em alta temporada a quantidade de resíduos aumenta e a quantidade de lixeiras se mantém, o que intensifica o impacto ambiental nessa temporada.

\section{9. ÁRVORES IMPRÓPRIAS}

Em alguns pontos foram detectadas calçadas comprometidas devido ao crescimento das raízes das árvores plantadas, além do fato de que as folhas dessas árvores eram grandes e apresentam risco potencial de entupimento de bocas de lobos. As espécies plantadas no meio urbano devem ser adequadas à localidade, e diversos estudos mostram as espécies mais indicadas para esse tipo de situação. Entretanto este aspecto ambiental foi pouco significativo na região.

\section{VEÍ́CULOS}

Este aspecto ambiental é mais intenso em alta temporada, quando o fluxo turístico é maior. Sabe-se que veículos em circulação podem liberar poluentes atmosféricos como monóxido de carbono derivado de processos de combustão incompleta e dióxido de nitrogênio e dióxido de carbono, além de material particulado. Considerando que a região apresenta uma dispersão de poluentes atmosféricos favoráveis em função da grande circulação de ar no local, este aspecto é mais suave quando comparado aos demais levantados nesta pesquisa.

A partir do LAIA gerado pode-se construir os Figuras 4 e 5, que expressam os resultados a partir da frequência de ocorrência dos eventos levantados em campo. A Figura 4 representa a pontuação total referente à frequência dos aspectos e impactos ambientais durante as duas estações da pesquisa, sendo, portanto, um gráfico que representa o LAIA geral obtido durante o período de análise.

Figura 4. Pontuação dos aspectos e impactos ambientais nas duas temporadas.

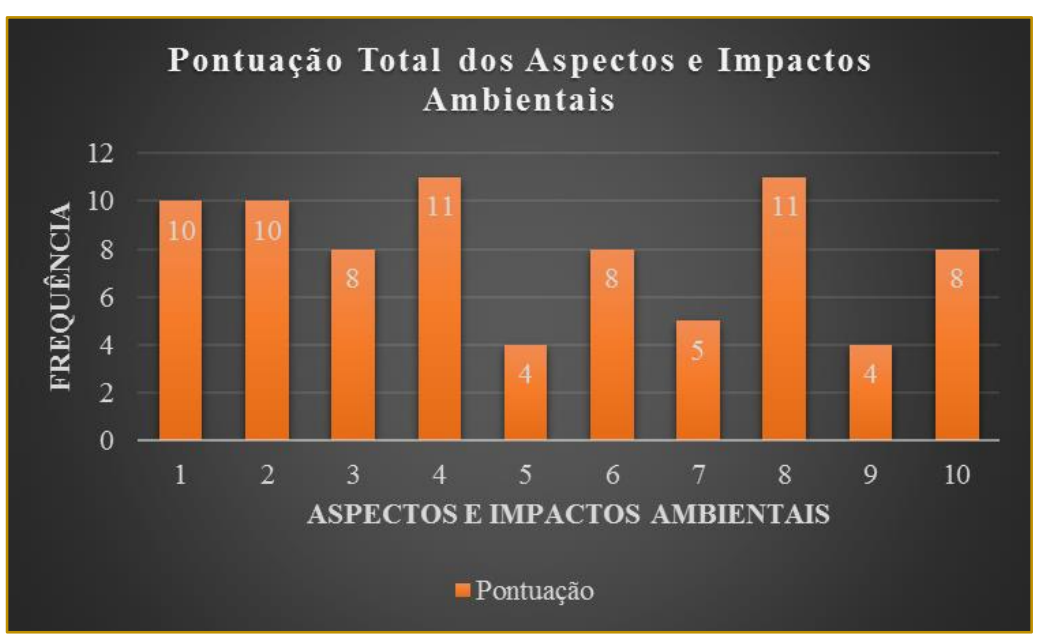

Observando a Figura 4 pode-se inferir que os aspectos e impactos ambientais referentes aos itens 4 e 8 são os que representam o maior grau de risco segundo a análise gráfica, uma vez que a pontuação atinge 0 valor de 11 para um máximo de 12 pontos. Esses itens correspondem aos aspectos de esgoto doméstico e lixeiras inadequadas, e os seus respectivos impactos ambientais enumerados na Tabela 1.

O segundo gráfico indicado pela Figura 5 representa a pontuação distinta entra as duas temporadas estudadas, em que se pode relacionar a variação de aspectos e impactos 
ambientais entre as duas estações. De maneira geral houve um aumento na frequência observada para os aspectos e impactos ambientais em alta temporada, entretanto em alguns casos ela se manteve. O LAIA representado pela Tabela 1 expressa 0 detalhamento referente a construção do segundo gráfico, que por sua vez permite uma visualização favorável a identificação dos elementos que sofreram maior variação.

Figura 5. Pontuação parcial dos aspectos e impactos ambientais em baixa (AIA(b)) e em alta temporada $(\mathrm{AI} A(\mathrm{a}))$.

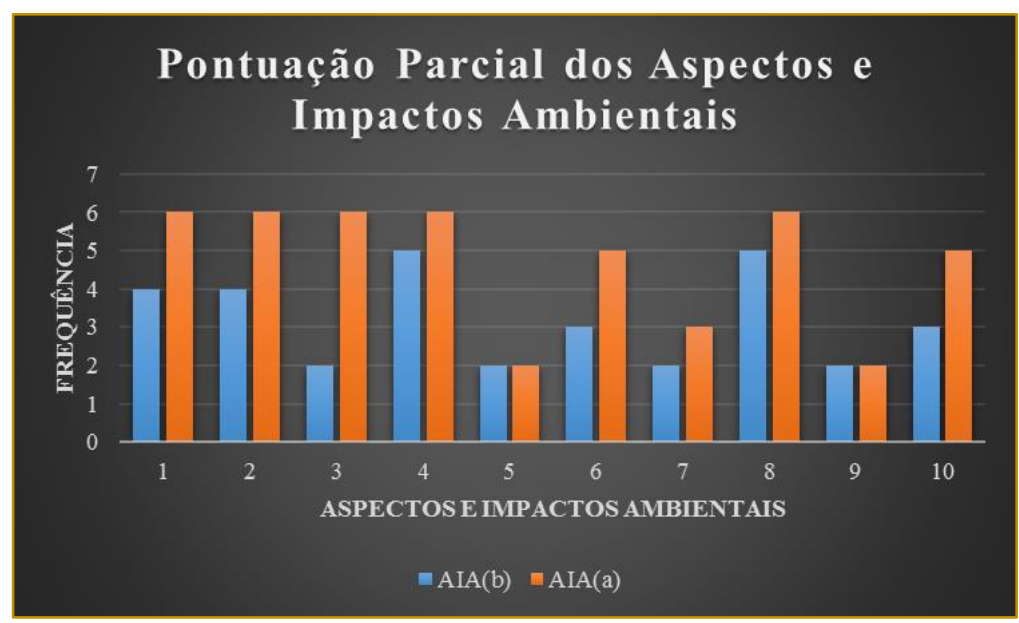

Analisando a Figura 5 pode-se notar que a maior discrepância entre as duas temporadas estudadas foi o item 3 , que corresponde ao aspecto ambiental de vidros e metais de origem comercial e não comercial, o que condiz com a realidade, uma vez que no verão os turistas lotam a região e o consumo de bebidas em latas e garrafas de vidro aumenta muito quando comparado ao inverno. Os aumentos nos resíduos sólidos de baixa para alta temporada também são destacados no gráfico, tanto de plástico como de papéis (itens 1 e 2). Vinculados aos maiores eventos de precipitação no período amostrado percebe-se uma intensificação nos impactos ambientais associados aos problemas de drenagem (item $6)$.

O item 10 que corresponde ao aumento de poluentes atmosféricos relacionados a circulação de veículos na região também sofre aumento, tal como o item 7 , que se refere ao aspecto de restos de alimentos e resíduos orgânicos, ambos relacionados ao aumento populacional no período de veraneio.

Traçando um paralelo entre as duas estações, percebe-se que elas se diferenciam, basicamente, apenas em termos quantitativos, e não qualitativos, isto é, a caracterização dos resíduos sólidos produzidos e dispostos naquela região não variam muito, entretanto a quantidade de resíduos sofre um grande acréscimo, e tal acréscimo não é adequadamente gerenciado, gerando volumes de resíduos que extrapolam e chegam em grandes quantidades no mar, circulando pelas correntes oceânicas e podendo causar uma ampla gama de impactos ambientais nos ecossistemas marinhos.

\subsection{DISCUSSÃO DO LAIA NOS ECOSSISTEMAS DE ILHAS E OCEÂNICOS}

Durante a visita técnica ao projeto TAMAR algumas informações relevantes foram coletadas, como o registro de diversos tipos de resíduos sólidos no estômago de sete tartarugas marinhas com aproximadamente 25 a $30 \mathrm{~cm}$ de casco, dentre estes resíduos destacam-se: linha de pesca, náilon, fio dental, tampinhas de refrigerantes, rótulos de embalagens e dentre outros. Estes resíduos podem ocasionar a morte desses organismos, além de dificuldades de locomoção e deformação no corpo de tartarugas em desenvolvimento.

A partir da caracterização dos tipos de resíduos sólidos encontrados nos estômagos dessas sete tartarugas marinhas, pode-se inferir a possibilidade de desague de esgoto doméstico no oceano, impactando severamente estes organismos, uma vez que materiais como fio dental, por exemplo, é um resíduo comum no 
esgoto doméstico, embora impróprio para tal destinação.

A situação destes animais marinhos corrobora para a importância em se desenvolver técnicas e projetos que sejam capazes de balizar a problemática dos resíduos sólidos no mar, como projetos de engenharia, educação ambiental, gestão urbana e costeira, e também destaca a importância da realização de diagnósticos ambientais constantes nas zonas de risco, monitoramento e controle, visando à recuperação de áreas impactadas quando possível.

Para destacar a importância dos ecossistemas e da dinâmica das ilhas, sabe-se que esses ambientes correspondem a $5 \%$ da cobertura terrestre do planeta, mas ainda assim abrigam cerca de um terço de todas as espécies de mamíferos, aves e anfíbios ameaçados, em sua maioria, composta por espécies de baixa variabilidade genética, 0 que frisa a vulnerabilidade desses ecossistemas perante os ecossistemas continentais (SERAFINI, FRANÇA, ANDRIGUETTO-FILHO, 2010).

O tipo de resíduo depositado na praia de Canasvieiras é uma ameaça à fauna marinha, uma vez que as características dos resíduos encontrados representam riscos à fauna de ilha e aos seres humanos. Dentre os tipos de materiais encontrados a maioria constitui-se de plásticos, sendo estes provavelmente os mais perigosos, devido tanto a ingestão quanto a possibilidade do animal se emaranhar. Estes materiais se espalham facilmente, sendo confundidos por peixes, aves e anfíbios com minhocas, enguias e outros organismos que fazem parte da alimentação dos mesmos.

Sabe-se também que a maior parte de resíduos encontrados no mar são plásticos, menores que $1 \mathrm{~cm}$, considerados micro plásticos, e quanto menor o seu tamanho, maiores são as chances de serem ingeridos por uma gama ainda maior de organismos marinhos e alguns tipos de aves. Os efeitos desses plásticos nos organismos dos indivíduos que os consomem são dos mais variados, com destaque em obstrução gastrointestinal. Estes materiais são altamente resistentes à degradação, demorando milhares de anos para serem decompostos, o que intensifica o dano ambiental (CÓZAR et al., 2014; SBERT-MATEU, et al., 2013; ORMEDILLA; PEREIRA; MONTEIRO, 2014).

Os resíduos sólidos que entram no mar pela praia de Canasvieiras, além da possibilidade de ocasionar impactos na própria ilha, podem também apresentar impactos ambientais transfronteiriços, uma vez que podem ser carregados pelas correntes marítimas para regiões mais distantes.

Entende-se por correntes marítimas os deslocamentos de massas de águas oceânicas, ordenadas ou não, causadas pela inércia de rotação do planeta, pelas variações de densidade, salinidade e pelos ventos. Estas correntes estão presentes em todo o globo terrestre, movimentando-se por todos os oceanos do mundo, transportando calor, sendo utilizadas por organismos marinhos como meio de transporte, e tendo forte influência em aspectos como clima, pesca e vida marinha. As principais correntes marítimas são: a Corrente do Golfo, Corrente do Brasil, Correntes de Humbolt, e entre outras (SILVEIRA et al., 2000).

Basicamente, a corrente brasileira, com suas variações de largura e velocidade ao longo de seu percurso, está associada ao giro subtropical do atlântico sul, que segundo Cózar e colaboradores (2014) é uma região de depósitos de resíduos. Esta corrente origina-se ao sul de $10^{\circ} \mathrm{S}$, na região onde o ramo mais ao sul da Corrente Sul Equatorial se bifurca, formando também a Corrente do Norte do Brasil, depois ela flui para o sul, bordejando o continente sulamericano até a região da Convergência Subtropical (33-38오 $)$ em que conflui com a Corrente das Malvinas e se separa da costa (SILVEIRA et al., 2000).

A entrada de todo o tipo de resíduos sólidos nos oceanos pode ser extremamente problemática e causar diversos prejuízos aos ecossistemas aquáticos, apresentando efeitos mensuráveis e imensuráveis. Dentre estes resíduos, o plástico está entre os mais problemáticos, pois atinge longas distâncias, acompanhado as correntes marinhas e causando diversos tipos de impactos transfronteiriços (JAMBECK et al., 2015; ORMEDILLA; PEREIRA; MONTEIRO, 2014).

Plásticos de origem continental entram no oceano em grande parte através de escoamento de águas pluviais, que fluem em cursos de água ou são diretamente depositados em águas costeiras. Estimar a entrada de plástico no oceano é uma tarefa complexa. Na década de 1970, a Academia Nacional de Ciências dos Estados Unidos estimou que o fluxo de plástico para os oceanos do mundo foi de 45.000 toneladas por ano, o equivalente a $0,1 \%$ da produção mundial de plástico. Desde então, a produção anual de plástico quintuplicou (265 milhões de toneladas por ano em 2010). Cerca de $50 \%$ do plástico produzido é flutuante. Esses 
materiais movimentam-se livremente pelo mar, seguindo as massas de águas predominantes e fixando-se em maior parte nas zonas de giro subtropical (CÓZAR et al., 2014).

Desta forma, considerando que os resíduos liberados na praia de Canasvieiras, em função do posicionamento geográfico da ilha, podem entrar neste sistema de propagação tem-se uma externalidade do dano ambiental, que não se restringe apenas a localidade em que o problema tem origem.

A carga orgânica de esgoto jogada no mar também pode afetar os ecossistemas marinhos e ambientes costeiros, especialmente em regiões de ilhas que são mais vulneráveis aos impactos ambientais do que os ecossistemas continentais. Em Canasvieiras a má qualidade da água, determinada pela análise visual dos efluentes detectados, pode ser um fator que representa uma ameaça aos ecossistemas locais, e unida aos resíduos sólidos que chegam ao mar torna-se um dos aspectos ambientais mais notáveis na localidade.

O resultado da pesquisa enfatiza a importância de ações coordenadas entre o poder público e a sociedade (população local, comércio e turistas), para diminuir a poluição na região e para uma conscientização dos problemas levantados. Uma possível solução seria a realização de projetos específicos de engenharia para os problemas encontrados, além de um programa de informação ambiental para os turistas e a população local, o que poderia evitar parte da poluição causada pelos mesmos.

Outros trabalhos citados no texto também permitem um embasamento teórico que destaca

\section{REFERÊNCIAS}

[1] Brasil. Política Nacional DE Resíduos Sólidos (PNRS). LEI № 12.305, DE 2 DE AGOSTO DE 2010. Disponível

<http://www.planalto.gov.br/ccivil_03/_ato2007-

2010/2010/lei/l12305.htm > Acesso: 02/04/2016.

[2] Cózar. A.; Echevarria. F.; González-Gordillo. J. I.; Irigoien. X.; Úbeda. B.; Hernández-León. S.; Palma. A. T.; Navarro. S.; García-de-Lomas. J.; RUIZ. A.; Fernández-De-Puelles. M. L.; Duarte. C. M. Plastic debris in the open ocean. July 15, vol. 111 no. 28 Proceedings of the National Academy of Sciences of the United States of America. PNAS. 2014.

[3] Cruz, F. P. da; Araújo, W. E. L. Avaliação Dos Aspectos e Impactos Ambientais No Setor de Abate de Um Frigorífero em Cachoeira Alta- GO. Revista Online UniRV, v. 1, p. 28-40, 2015. a importância de se implementar medidas de gerenciamento ambiental local, visando o equacionamento de problemas ambientais em pequena escala, para que os impactos ambientais globais sejam minimizados cada vez mais, e os danos ambientais detectados em grande escala sejam reduzidos ou até mesmo eliminados.

\section{CONCLUSÃO}

A realização desta pesquisa permitiu a construção de um LAIA que indicou maiores riscos ambientais associados aos resíduos sólidos e aos efluentes líquidos que entram nos ecossistemas marinhos, podendo ocasionar perda de biodiversidade, além de outros aspectos e impactos ambientais detectados no norte da ilha de Florianópolis, Casnasvieiras. Também permitiu a indicação de medidas mitigatórias ou preventivas aplicáveis para cada situação levantada.

A revisão da literatura e os resultados dos trabalhos de campo frisam a importância da implementação de medidas de gestão ambiental e costeira, especialmente em ecossistemas de ilhas e ambientes marinhos que sejam capazes de equacionar a problemática local, contribuindo assim, para uma redução nos impactos ambientais globais, assim como destacam a importância de dados e informações técnicas que sirvam como base para o processo de tomada de decisão pelos órgãos gestores competentes, como o levantamento de aspectos e impactos ambientais.

[4] Eller, J. R.; Santos, L.; Nascimento, R. S. Analise Ambiental Do Manguezal Do Rio Tavares. Florianópolis. 2013. Disponível em: http://observatoriogeograficoamericalatina.org.mx/ega |14/Procesosambientales/Impactoambiental/03.pdf Acesso: 10/10/2016

[5] Freire, L. C. M. E.; Lopes, V. DA S. S. M.; SÁ, M. G. S. Abordagem Socioeconômica e EcológicoCultural da Ilha Do Príncipe / São Gomes, L. P. et al. Avaliação ambiental de aterros sanitários de resíduos sólidos urbanos precedidos ou não por unidades de compostagem. Engenharia Sanitaria e Ambiental, v. 20, p. 449-462, 2015.

[6] Jambeck. J. R.; Geyer. R.; Wilcox. C.; Siegler. T. R.; Parryman. M.; andrady. A.; Narayan. R.; Law. K. $\mathrm{L}$. Plastic waste inputs from land into the ocean. Science 13 Feb Vol. 347, Issue 6223, pp. 768-771. DOI: 10.1126/science.1260352. 2015. 
[7] Mazzer. A. M. Proposta Metodológica para Análise de Vulnerabilidade da Orla Marítima à erosão Costeira: Aplicação em praias arenosas da costa sudeste da llha de Santa Catarina (Florianópolis Santa Catarina - Brasil). Universidade Federal do Rio Grande do Sul (UFRGS). Instituto de Geociências. Programa de Pós-Graduação em Geociências. Porto Alegre. 2007. Disponível em: http://www.ufrgs.br/igeo/pesquisas/3601/10-3601.pdf Acesso 15/11/2016.

[8] Ormedilla, A. C.; Pereira, T. B.; Monteiro, M. $Z$. Analysis of antropogenic waste found in the digestive tract of green turtles ( Chelonia mydas). BioScience, v. 3, p. 83-89, 2014.

[9] Pmf. Prefeitura Municipal De Florianópolis. 2016. Disponível em: http://www.pmf.sc.gov.br Acesso: 11/05/2016.

[10] Sbert-Mateu, J. M.; Cabello-Ricci, I.; OlivesVillalonga, E.; Irigoyen-Cabeza, E. The impact of tourism on municipal solid waste generation: The case of Menorca Island (Spain). Waste Management, V.33, P. 2589-2593, 2013
[11] Serafini, T. Z; França, G. B; Filho, J. M. A. Brazilian oceanic islands: known biodiversity and its relation to the history of human use and occupation. Journal of Integrated Coastal Zone Management. 2010.

[12] Silveira, I. C. A., Schmidt, A. C. K., Campos, E. J. D., Godoi, S. S., Ikeda, Y. A corrente do Brasil ao Largo da Costa Leste Brasileira. Instituto Oceanográfico da Universidade de São Paulo (Caixa Postal 66149, 05315-970 São Paulo, SP, Brasil). Rev. bras. oceanogr.. 48(2):171-183. 2000.

[13] Tomazela D. P. Monitoramento Espacial e Temporal de Parâmetros Físicos, Químicos, e Biológicos da Bacia Hidrográfica do Rio Capivari. (Norte da Ilha de Santa Catarina). Universidade Federal de Santa Catarina (UFSC). Instituto de Ciências Biológicas. Florianópolis. 2008. Disponível em: $\quad$ http://www.limnos.ufsc.br/assets/docs/TCCDANILO.pdf Acesso: 12/10/2016.

[14] Tomé E Príncipe: desafios à gestão ambiental local. Revista de Geografia e Interdisciplinaridade, v. 2, p. 269-290, 2016. 


$$
\text { Alutary }
$$




\section{FABIANE DOS SANTOS TOLEDO (Organizadora)}

Mestre em geografia pela Universidade Federal de Uberlândia, na área de planejamento ambiental, atuante em geociências, com ênfase em ambiental - áreas verdes, índice de áreas verdes, espaços públicos livres e parques urbanos. Possui graduação em Geografia (Licenciatura e Bacharelado) pela Universidade Federal de Uberlândia, mestrado em geografia pela Universidade Federal de Uberlândia. Tem experiência na área de Geociências, com ênfase em Geografia ambiental, atuando principalmente nos seguintes temas: áreas verdes, índice de áreas verdes, espaços públicos livres e parques urbanos.

\section{ADRIANA MARIA IMPERADOR}

Doutora em Ciências da Engenharia Ambiental pela Universidade de São Paulo - Escola de Engenharia de São Carlos, Brasil Professora na Universidade Federal de Alfenas (UNIFALMG), Campus Poços de Caldas. Instituto de Ciência e Tecnologia. Rodovia José Aurélio Vilela, BR 267, Km 533, 11999 - Cidade Universitária, Poços de Caldas - MG, 37715-400.

\section{ALAN DA SILVA SAMPAIO}

Gestor Ambiental, pela Universidade Federal de Rondônia. Tem experiência em área ambiental.

\section{ALDENIR FEITOSA DOS SANTOS}

Possui mestrado em Química e Biotecnologia pela Universidade Federal de Alagoas (1997) e doutorado em Química e Biotecnologia pela Universidade Federal de Alagoas (2005). Atualmente é coordenadora stricto sensu da coordenação de pesquisa e pós-graduação do Centro Universitário CESMAC. Também atua como professora e pesquisadora no Curso de Mestrado Profissional de Pesquisa em Saúde e no Curso de Medicina. É professora titular e pesquisadora do Curso de Licenciatura em Química da Universidade Estadual de Alagoas onde também coordena o Núcleo de química do PIBID/UNEAL. Tem experiência na área de fitoterapia e fitoquímica, com ênfase em química de compostos bioativos, atuando principalmente nos seguintes temas: atividade antioxidante, cicatrizante, moluscicida, cercaricida, antiesquistossomótica e hipoglicemiante de espécies vegetais, incluindo também seus resíduos. A pesquisa por composto naturais bioativos é sua principal área de atuação e dentro desta linha fez o pós-doutorado no Instituto de Química e Biotecnologia da UFAL, Laboratório de Pesquisa em Recursos Naturais - LPqRN, na área de produtos naturais com ação anti-HIV e antioxidante.

\section{ALESSANDRA LEE BARBOSA FIRMO}

Professora e pesquisadora do Instituto Federal de Educação, Ciência e Tecnologia de Pernambuco (IFPE) desde julho de 2009, no curso de Tecnologia em Gestão Ambiental. Líder do Grupo de Resíduos Sólidos do IFPE e membro do Grupo de Resíduos Sólidos da UFPE (GRS/UFPE). Bolsista de Produtividade em Pesquisa 2015/2016. Diretora de Extensão do IFPE em 2014-2015. Graduação em Eng. Química pela UFPE (2006), em Tecnologia em Gestão Ambiental em (2008), Mestrado em Eng. Civil pela UFPE (2008) e Dra. em Eng. Civil pela UFPE (2013). Participou como pesquisadora de projetos financiados pelo CNPq, FINEP, FACEPE, CHESF, BNDES e Foundation CMG nas áreas de geotécnica ambiental, resíduos sólidos, biodegradação e geração de biogás, geração de energia em aterros, plano de gerenciamento integrado de resíduos sólidos, interação rocha-fluido, estudo de modelos numéricos de geração e fluxo em meios porosos. 


\section{ALESSANDRA MARIA FILIPPIN DOS PASSOS}

Economista, Mestranda no Programa de Pós-Graduação em Ciências Ambientais pela Universidade do Estado de Mato Grosso - Campus de Cáceres-MT.

\section{ANA CLARA DE BARROS}

Possui graduação em Agronomia pela Faculdade de Ciências Sociais e Agrárias (FAIT) de Itapeva (SP), em 2014. Mestrado em Agronomia pela Universidade Estadual Paulista Júlio de Mesquita Filho (2017). Atualmente cursa Doutorado no programa de Agronomia pela UNESP/FCA. Tem experiência na área de Agronomia, com ênfase em Cultivo do Milho e também, em Licenciamento Ambiental e Planejamento e Gestão dos Recursos Hídricos, além de conhecimentos em Geotecnologias.

\section{ANA LUCY CAPRONI}

Possui graduação em Engenharia Florestal pela Universidade José do Rosário Vellano (1984), mestrado em Agronomia (Fitotecnia) pela Universidade Federal de Lavras (1991) e doutorado em Agronomia Fitotecnia pela Universidade Federal Rural do Rio de Janeiro (2001), Pós doutorado pela Universidade de Buenos Aires (2004). Atualmente é professora Associada III do Departamento de Gestão Ambiental do Campus de Guajará Mirim da Universidade Federal de Rondônia. Tem experiência na área de Recursos Florestais e Engenharia Florestal, com ênfase em Sementes Florestais, atuando principalmente nos seguintes temas: Silvicultura, Paisagismo, Agroecologia, Sistemas Agroflorestais, diversidade, fma, áreas degradadas, ecologia do solo, Trabalho de Conclusão de Curso e Metodologia de Pesquisa.

\section{ANA PAULA LEITE}

Possui graduação em Geografia pela Universidade Estadual Paulista Júlio de Mesquita Filho (2015). Atualmente cursa Mestrado no programa de Agronomia pela UNESP/FCA. Tem experiência em sensoriamento remoto e geoprocessamento no monitoramento e planejamento do uso da terra.

\section{ANDRÉ AGUIAR BATTISTELLI}

Possui graduação em Engenharia Ambiental pela Universidade Estadual do Centro-Oeste-PR (2014) e Doutorado em Engenharia Ambiental pela Universidade Federal de Santa Catarina (2018), para o qual foi aprovado por meio de transferência direta de mestrado para doutorado. Atualmente é pós-doutorando (PDJ-CNPq) no programa de Pós-graduação em Engenharia Ambiental da Universidade Federal de Santa Catarina.

\section{ANDRESSA CORRÊA LEITE}

Pós graduada em Engenharia de Segurança do Trabalho, graduada em Engenharia Ambiental e Técnica de Segurança do Trabalho. Atualmente atuando com documentação do Sistema de Gestão Integrado de uma multinacional do ramo metalúrgico.

\section{ANGELA CRISTINA MÉLO-SCHLUB}

Graduação em Engenharia HES (Alta Escola Superior) em Gestão Ambiental no Cantão de Genebra/Suíça na École d'Ingénieurs de Lullier - 1298 (Escola de Engenheiros de Lullier). Graduação no Curso Superior de Tecnologia em Sistema de Gestão Ambiental no Instituto Federal de Pernambuco (IFPE) - 2017. Bolsista do CNPq 2014-2016 atuando no Laboratório de Microbiologia Ambiental e Industrial (LAMAI) da Universidade Federal de Pernambuco (UFPE) e no laboratório do Grupo de Resíduos Sólidos (GRS) da UFPE. Conhecimento prático no software: Spring 5.2, Terra View 4.2, MemoQ e pacote Windows. Tradutora e intérprete nos 
pares FR/PT - PT/FR em produção científica, literária e audiovisual, nos seguintes temas: ambiental, agricultura, saneamento, microbiologia e biotecnologia.

\section{ANNE MARCELLE GUIMARÃES SALES}

Mestra em Ciências e Meio Ambiente pelo Instituto de Ciências Exatas e Naturais da Universidade Federal do Pará - ICEN/UFPA. MBA em Logística e Supply Chain pela Faculdades Metropolitanas Unidas (FMU/SP). Pós-graduação Lato Sensu em Engenharia de Produção pela Universidade Federal do Amazonas (2008). Graduada Bacharela em Administração pela Universidade Federal do Amazonas (2006). Sólida experiência de mais de 14 anos em empresas certificadas e em implantação e manutenção de Sistemas de Gestão da Qualidade \& Meio Ambiente, no segmento Industrial do polo de duas rodas (empresa japonesa) e eletroeletrônico. Auditora Líder da Qualidade (ISO 9001:2015) e Meio Ambiente (ISO 14001:2015) com certificação internacional reconhecida pelo IRCA. Atualmente é professora do Centro Universitário do Norte (UniNorte/Laureate), onde leciona e compõe o NDE dos cursos de Gestão da Qualidade, Logística, Marketing, Gestão Comercial e Gastronomia. Membro da equipe de Elaboração e Validação de Itens do Exame Nacional de Desempenho de Estudantes (ENADE) da UniNorte/Laureate.

\section{AUMERI CARLOS BAMPI}

Doutor em Filosofia e Ciências da Educação pela USC, Espanha. Docente da Faculdade de Educação e Linguagem e dos Programas de pós-graduação em Ciências Ambientais (PPGCA) e Geografia (PPGEO) da Universidade do Estado de Mato Grosso. Professor da Faculdade de Educação e Linguagem - UNEMAT. Av. dos Ingás, 3001. Campus de Sinop, Sinop/MT, Brasil.

\section{BEATRIZ ISABELLA DA SILVA PEREIRA}

Graduada em Engenharia Ambiental pela Universidade de Sorocaba - UNISO. Atuou como Educadora Ambiental pela Secretária do Meio Ambiente de Sorocaba. Foi voluntária auxiliando em diversas pesquisas pelo Laboratório de Toxicologia da Universidade de Sorocaba - LAPETOX.

\section{DÁRIA MARIA CARDOSO NASCIMENTO}

Possui graduação em Geografia (Licenciatura/Bacharelado), doutora em Geologia Costeira UFBA; especialização em Cartografia Avançada no IAGS/CSDMA, na Zona do CanalPanamá. Geógrafa e professora do Departamento e do Programa de Pós-Graduação em Geografia IGEO/UFBA, onde Coordena o Laboratório de Cartografia - LACAR. É membro da Comissão Estadual de Cartografia e de Geoinformação - CECAR/BA, representando a Sociedade Brasileira de Cartografia - SBC.

\section{DAVI DO SOCORRO BARROS BRASIL}

Possui graduação em Química Industrial pela Universidade Federal do Pará (1995), graduação em CIÊNCIAS (LICENCIATURA EM QUÍMICA) pela Universidade Federal do Pará (2002) e mestrado e Doutorado em Química pela Universidade Federal do Pará (1999, 2008). Atualmente é professor Associado I da Universidade Federal do Pará. Tem experiência na área de Química, com ênfase em Química dos Produtos Naturais, Química Teórica e desenvolvimento tecnológico, atuando principalmente nos seguintes temas: fitoquímica, modelagem molecular, desenvolvimento de biomateriais. 


\section{DIEGO LEON DA SILVA MONTEIRO}

Bacharelando em Ciências Náuticas, com especialização em Máquinas, no Centro de Instrução Almirante Braz de Aguiar - Escola de Formação de Oficiais da Marinha Mercante

\section{FLÁVIA KARENINE SILVA DA PONTE}

Possui graduação em Comunicação Social pelo Centro Universitário do Norte (2002). Atualmente é professora titular do Centro Universitário do Norte (UNINORTE) e do Centro Integrado de Ensino Superior da Amazônia(CIESA). Tem experiência na área de Comunicação, com ênfase em Programação de Rádio e Televisão, atuando principalmente nos seguintes temas: imagem, plano de negócios, eleição, crise e estratégia. Especialização em Marketing Empresarial (2003 - 2004) - Universidade Federal do Amazonas(UFAM). Especialização em Docência Superior (2011 - 2012) - Centro Integrado de Ensino Superior da Amazônia (CIESA). Mestrado profissional em Ciências e Meio Ambiente (2017 - 2018) Universidade Federal do Pará (UFPA).

\section{FLÁVIO RUBENS LAPOLLI}

Professor da Universidade Federal de Santa Catarina desde 1976. Possui graduação em Engenharia Civil pela Universidade Federal de Santa Catarina (1976), mestrado em Engenharia de Produção pela Universidade Federal de Santa Catarina (1993) e doutorado em Engenharia Hidráulica e Saneamento pela Universidade de São Paulo (1998) com "Sandwich" - Universite de Montpellier II (Scien. et Tech Du Languedoc) (1997).

\section{GABRIELA MATEUS DE FONTES SILVA}

Engenheira Ambiental pela Universidade Estadual do Sudoeste da Bahia, Mestranda do Programa de Pós-Graduação em Ciências e Tecnologias Ambientais da Universidade Federal do Sul da Bahia / Instituto Federal da Bahia, Campus Porto Seguro

\section{GIOVANNA FRANÇA BISPO DA GAMA}

Graduanda do Bacharelado Interdisciplinar em Ciências da Universidade Federal do Sul da Bahia, Campus Teixeira de Freitas

\section{GLÁUCIA REGINA SANTOS}

Possui graduação em Engenharia Florestal (2011) pela Universidade Federal de Lavras (UFLA). Na Faculdade de Ciências Agronômicas da Universidade Estadual Paulista Júlio de Mesquita Filho (FCA/UNESP) cursou o Mestrado (2016). Atualmente é doutoranda do programa de pós-graduação em Recursos Florestais da Universidade de São Paulo, campus de Piracicaba (ESALQ/USP). Tem experiência na área de recursos florestais com ênfase em bacias hidrográficas, produção de mudas nativas/ exóticas, trilhas ecoturísticas, recuperação de áreas degradadas, ciclagem de nutrientes, decomposição de serapilheira e macroinvertebrados aquáticos.

\section{GRAZIELLA SARPE CAPO}

Graduada em Ciências Biológicas pelo Centro Universitário Fundação Santo André e Engenharia Química pela Faculdade de São Bernardo do Campo. Realizei pesquisas de Iniciação Científica em ambas as faculdades e fui bolsista do CNPq em uma delas. 


\section{GUSTAVO HENRIQUE AMARAL MONTEIRO ROCHA}

Graduando em Engenharia Química pela Universidade Federal de Goiás. Técnico em Química pelo Instituto Federal de Educação, Ciência e Tecnologia. Fundador e diretor executivo da companhia Nutricandies. Criador dos chocolates nutritivos à base de vegetais. Líder da equipe finalista do Thought for Food 2018. Atua com ênfase na área de desenvolvimento de produtos, química dos alimentos e otimizações para tratamento de efluentes em indústrias alimentícias.

\section{HELANE CARINE DE ARAÚJO OLIVEIRA}

Possui graduação em Agronomia pela Universidade Federal de Alagoas (2002). Especialista em Gestão Estratégica de Empresas e Marketing pelo Centro de Estudos Superiores de Maceió - CESMAC (2006). Especialista em Gestão e Educação Ambiental pela Universidade Federal de Alagoas (2009). Mestranda em Análise de Sistemas Ambientais pelo Centro Universitário CESMAC (2017). Ensinou em escolas municipais de Coruripe (de 2004 a 2006). Coordenou a Educação Ambiental das escolas municipais de Coruripe pela Secretaria de Educação de Coruripe (de 2007 a 2010). Desde 2010 está no Instituto Federal de Alagoas como professora de meio ambiente. Desde 2014 está na chefia de departamento acadêmico do IFAL - Campus Coruripe.

\section{HELEN RITA MENEZES COUTINHO}

Atualmente cursa doutorado em Turismo e Hotelaria na Universidade do Vale do Itajaí (UNIVALI), possui mestrado em Administração pela Universidade Federal de Santa Catarina (2003), graduação em Curso de Turismo pela Universidade de Fortaleza (1996). É professora concursada da Universidade do Estado do Amazonas (UEA). Tem experiência na área de Turismo e Administração, com ênfase em Turismo e Educação, atuando principalmente nos seguintes temas: diagnóstico, qualidade em serviços, infraestrutura de apoio, turismo, educação, saúde pública e metodologia da pesquisa. Possui experiência de gestão na área de Educação Superior, atuou como Coordenadora dos Cursos de Turismo, Letras, Geografia, Marketing e Gastronomia.

\section{HYGOR ARISTIDES VICTOR ROSSON}

Graduado em Engenharia Ambiental pela Universidade Federal de Viçosa (2005), mestre em Ciência Florestal pela mesma instituição (2007) e Doutor em Saneamento, Meio Ambiente e Recursos Hídricos pela Universidade Federal de Minas Gerais (2015). Atualmente é professor da Universidade Federal de Viçosa - Campus de Florestal. Tem experiência na área de Engenharia Sanitária e Ambiental, com ênfase em Controle da Poluição e Saneamento, atuando, principalmente, nos seguintes áreas temáticas: políticas públicas de saneamento, tratamento e reutilização de efluentes ou águas residuárias; gerenciamento de resíduos sólidos, monitoramento e controle ambiental e gerenciamento de recursos hídricos. Foi o primeiro coordenador do Curso Superior de Tecnologia em Gestão Ambiental e Diretor de Ensino da UFV - Campus de Florestal. Recentemente atua como membro do Núcleo Docente Estruturante (NDE) e Coordenador Suplente do Curso Superior de Tecnologia em Gestão Ambiental. Coordena as seguintes disciplinas: i) Controle Ambiental na Indústria; ii) Coleta e Tratamento de Águas Residuárias; iii) Gestão Ambiental; iv) Manejo e Tratamento de Poluentes; v) Ética e Atuação Profissional; vi) Qualidade da Água e Tratamento de Resíduos; vii) Sustentabilidade Ambiental e viii) Turismo e Meio Ambiente. Recentemente (2017) vem atuando como docente e orientador permanente do Programa de Pós-Graduação em Sustentabilidade e Tecnologia Ambiental (Mestrado Profissional) do Instituto Federal de Minas Gerais - Campus Bambuí, desenvolvendo trabalhos nas linhas de pesquisas referentes a Gestão e Planejamento Ambiental e Tecnologia Ambiental. As orientações estão sendo desenvolvidas nas seguintes áreas de interesses: i) Planejamento, Gestão e Avaliação de Políticas Públicas de Saneamento; ii) Tecnologias de Tratamentos de Águas de Abastecimento e Residuárias; e iii) Controle Ambiental em Processos Agrícolas e Industriais. 


\section{ISAAC VOLSCHAN JUNIOR}

Engenheiro Civil e Sanitarista, M.Sc. em Engenharia Sanitária, D.Sc em Engenharia de Produção. Professor Titular do Depto. de Recursos Hídricos e Meio Ambiente da Escola Politécnica da UFRJ. Atua nos cursos de Graduação e Pós-graduação em Engenharia Civil e Engenharia Ambiental da UFRJ. Coordenador do Curso de Especialização em Engenharia Sanitária e Ambiental da UFRJ. Coordenador do Centro Experimental de Saneamento Ambiental da UFRJ. Coordenador de projetos de pesquisa no âmbito de programas da FINEP, CNPq, CAPES, FAPERJ e CYTED. Consultor da Fundação COPPETEC e de outras entidades para estudos e projetos de engenharia aplicados ao saneamento ambiental urbano. Membro do Conselho Diretor da Associação Brasileira de Engenharia Sanitária e Ambiental.

\section{JANAÍNA DOS SANTOS FERREIRA}

Possui graduação em Engenharia Química pela Universidade Estadual de Maringá (2011), mestrado em Engenharia Química pela Universidade Federal de São Carlos (2014) na área de Controle Ambiental e Doutorado em Engenharia de Processos Químicos e Bioquímicos (Engenharia Química) com ênfase em Tecnologia Ambiental pela Universidade Federal do Rio de Janeiro (2017). Foi Professora substituta EBTT no Instituto Federal de São Paulo, ministrando aulas principalmente no curso de graduação em Tecnologia de Processos Químicos. Atualmente é professora (EaD) no curso de bacharelado em Engenharia Ambiental junto à UAB-UFSCar e Professora Substituta pela Fundação Universidade Regional de Blumenau ministrando disciplinas de termodinâmica no curso de Engenharia Mecânica. Tem experiência na área de Engenharia Química (Ambiental), com ênfase em Tratamento de Efluentes e Digestão Anaeróbia para produção de Biogás e Bioenergia, atuando principalmente nos seguintes temas: Bioenergia, biomassa, biodiesel, produção biológica de hidrogênio, codigestão de resíduos sólidos urbanos e industrias com Lodo de Esgoto.

\section{JESSÉ MARQUES DA SILVA JÚNIOR PAVÃO}

Possui graduação em Agronomia pela Universidade Federal de Alagoas (2006) Mestrado em Agronomia/Fisiologia Vegetal pela Universidade Federal de Lavras (2007) e Doutorado em Agronomia/Fisiologia Vegetal, pela mesma instituição (2009). No mestrado estudou e desenvolveu metodologias para a degradação (quebra) da parede celular em monocotiledôneas usando Protoplastos. Durante o doutoramento estudou a atividade da enzima Fenilalanina Amônio Liase (PAL) relacionada aos processos de lignificação da parede celular. Tem experiência na área de Fisiologia Vegetal, atuando principalmente nos seguintes temas: Biotecnologia vegetal: Protoplastos e Cultura de tecidos. Anatomia vegetal: estrutural e quantitativa. Plantas infestantes: Matologia, Tecnologia de aplicação de Herbicidas, Modo de ação e Mecanismo de Ação. Microscopia eletrônica de varredura e transmissão. Realizou pós-doutorado no Seed Conservation Department, Royal Botanic Gardens, Kew, Wakehurst Place, West Sussex - England, onde desenvolveu pesquisas para compreender as bases da Tolerância a Dessecação em semente. É pesquisador do Centro de Referência em Recuperação de Áreas Degradas (CRAD) do Baixo São Francisco, da Universidade Federal de Alagoas, desenvolvendo trabalhos de pesquisa na área de recuperação de áreas degradadas por meio de implantação e estabelecimento de modelos de regeneração vegetacional. Professor e pesquisador do Centro Universitário Cesmac e atualmente Coordenador do Programa de Pós-Graduação Análise de Sistemas Ambientais - PPGASA. Palavras-chave do meu interesse para realização de trabalhos: Empreendedorismo. Startups. Energias Renováveis (Eólica e Solar). Sistemas Agroalimentares Locais. Fisiologia do estresse em sementes. Armazenamento de sementes. Mandioca. Herbicida. Interação entre planta $\mathrm{x}$ ambiente. Alelopatia. 


\section{JOÃO BAPTISTA CHIEPPE JÚNIOR}

Possui graduação em Engenharia Agronomica pela Escola Superior de Agronomia de Lavras (1987), curso especialização em Irrigação e Drenagem pela SBEA/Universidade Federal de Viçosa (1991), Curso de aperfeiçoamento em Tecnologia Agrícola e Irrigação pelo GALILEE INTERNATIONAL MANAGEMENT INSTITUTE DE ISRAEL (2011), Pós graduação Latu Sensu em Gestão da Agroindústria Sucroalcooleira pela Universidade Federal de Campina Grande/Universidade Federal do Mato Grosso (2010), mestrado em Agronomia (Irrigação e Drenagem) pela Universidade Estadual Paulista Júlio de Mesquita Filho (1993) e doutorado em Agronomia (Irrigação e Drenagem) pela Universidade Estadual Paulista Júlio de Mesquita Filho (1998). Atualmente é Professor Titular efetivo $1^{\underline{0}}$ e $2^{\circ}$ graus do Instituto Federal de Educação, Ciência e Tecnologia de Goiás, Campus Inhumas-GO. Tem experiência na área de Agronomia, com ênfase em Irrigação e Drenagem, atuando principalmente nos seguintes temas: feijoeiro, irrigação, solo, água e meio ambiente. Atua ambém nas áreas de gestão ambiental, meio ambiente e aproveitamento de resíduos sólidos e também na área sucroalcooleira. Atualmente faz pós doutoramento no Instituto Superior de Agronomia ISA Lisboa Portugal na área de química ambiental com o título INTEGRATED ANIMAL SLURRY TREATMENT TO ALLOW THE USE OF RESULTING PRODUCTS IN INDUSTRIAL HORTICULTURE.

\section{JOÃO BATISTA LOPES DA SILVA}

Engenheiro Agrícola e Doutor em Engenharia Agrícola pela Universidade Federal de Viçosa, Professor da Universidade Federal do Sul da Bahia, Campus Teixeira de Freitas

\section{JOÃO GOMES DA COSTA}

Possui graduação em Engenharia Agronômica pela Universidade Federal de Alagoas (1985), mestrado em Genética e Melhoramento pela Universidade Federal de Viçosa (1995) e doutorado em Biotecnologia - RENORBIO pela Universidade Estadual do Ceará (2010). Atualmente é pesquisador da Empresa Brasileira de Pesquisa Agropecuária - Embrapa Tabuleiros Costeiros e Professor do programa de Pós-Graduação em Agricultura e Ambiente da Universidade Federal de Alagoas e Professor do Centro Universitário CESMAC. Tem experiência na área de Agronomia, com ênfase em Melhoramento Vegetal e Ecologia Química, atuando principalmente nos temas: melhoramento de frutíferas e uso de semioquímicos na agricultura.

\section{JOÃO SÉRGIO CORDEIRO}

Possui graduação pela Escola de Engenharia de São Carlos, da Universidade de São Paulo (1975), mestrado em Engenharia Hidráulica e Saneamento pela Universidade de São Paulo (1981) e doutorado em Engenharia Hidráulica e Saneamento pela Universidade de São Paulo (1993). Atualmente é professor Titular (aposentado) da Universidade Federal de São Carlos. Tem experiência na área de Engenharia Sanitária, com ênfase em tratamento de lodos de ETAs, atuando principalmente nos seguintes temas: drenagem urbana, gerenciamento de Sistemas de Saneamento, estacões de tratamento de água, lodos de decantadores e resíduos sólidos. Foi Diretor e Presidente da ABENGE - Associação Brasileira de Educação em Engenharia.

\section{JORGE HERÁCLITO DE MATTOS}

Possui graduação em Ciências Biológicas pela Universidade Nova Iguaçu Licenciatura Plena- RJ - UNIG (1993). Possui Especialização (Lato sensu) em Ensino Superior e Mestrado em Ciências da Linguagem pela Universidade Federal de Rondônia - UINIR - Campus Guajará-Mirim- RO. Atualmente é Professor Assistente I da Fundação Universidade Federal de Rondônia - UNIR, Lotado no Departamento de Gestão Ambiental. Atua também na área de Educação, com ênfase em Educação Ambiental, Linguagem, Biologia, Ciências Ambientais, Pedagogia e Letras. É Conselheiro Titular do Deliberativo da Reserva Extrativista Estadual do 
Rio Pacaás Novos desde abril de 2012. Doutorando em Biologia do Solo pela Universidade Rural do Rio de Janeiro- UFRRJ.

\section{JORGE LUIZ HERACLITO DE MATTOS}

Possui graduação em Ciências Biológicas pela Universidade Nova Iguaçu Licenciatura Plena- RJ - UNIG (1993). Possui Especialização (Lato sensu) em Ensino Superior e Mestrado em Ciências da Linguagem pela Universidade Federal de Rondônia - UFRO - Campus Guajará-Mirim- RO. Atualmente é Professor Assistente I da Fundação Universidade Federal de Rondônia - UFRO, Lotado no Departamento de Gestão Ambiental. Atua também na área de Educação, com ênfase em Educação Ambiental, Linguagem, Biologia, Ciências Ambientais, Pedagogia e Letras. . Doutorando em Biologia do Solo pela Universidade Rural do Rio de Janeiro- UFRRJ.

\section{JOSÉ RODOLFO DANTAS DE OLIVEIRA GRANHA}

Possui graduação em Engenharia Florestal pela Universidade Federal Rural do Rio de Janeiro (1994), mestrado em Agronomia (Ciências do Solo) pela Universidade Federal Rural do Rio de Janeiro (1998) e doutorado em Agronomia pela Universidade Federal do Rio de Janeiro (2003). Foi professor do curso de pós graduação de Ciência do Solo e Meio Ambiente, atualmente é Professor Adjunto do curso de Graduação de Gestão Ambiental da Fundação Universidade Federal de Rondônia (UNIR) das disciplinas de Ecologia e Fauna e Flora. Tem experiência em Fertilidade do Solo, Nutrição Mineral de Plantas, Solos Florestais, Desenvolvimento Sustentável, Manejo e Conservação do Solo, Física, Ecologia Geral e Biologia do Solo, atuando principalmente nos seguintes temas: Ecologia matemática, diversidade, ecossistemas brasileiros, manejo e conservação dos solos, classificação dos solos, biologia do solo, fauna do solo e micorrizas.

\section{JOSÉ RODOLFO DATAS DE OLIVEIRA GRANHA}

Possui graduação em Engenharia Florestal pela Universidade Federal Rural do Rio de Janeiro (1994), mestrado em Agronomia (Ciências do Solo) pela Universidade Federal Rural do Rio de Janeiro (1998) e doutorado em Agronomia pela Universidade Federal do Rio de Janeiro (2003). Foi professor do curso de pós graduação de Ciência do Solo e Ambiente, atualmente é Professor Adjunto do curso de Graduação de Gestão Ambiental da Fundação Universidade Federal de Rondônia (UNIR) das disciplinas de Gestão de Unidades de Conservação e de Gestão de Recursos Hídricos. Tem experiência em Fertilidade do Solo, Nutrição Mineral de Plantas, Solos Florestais, Desenvolvimento Sustentável, Manejo e Conservação do Solo, Física, Ecologia Geral e Biologia do Solo.

\section{JULIANA ARAUJO DA SILVA}

Técnica em Análises Químicas, graduanda em Engenharia Química pela Faculdade São Bernardo (2019). Possui experiência industrial no segmento de cosméticos, na melhoria contínua (TPM), conhecimentos práticos em análises físico-químicas e instrumentais. Participou de projetos de conversão de resíduos sólidos em energia por rota térmica e na área de formulação e pesquisa de inibidores verdes de corrosão.

\section{JULIANA DE CARVALHO PEDROSO SILVA}

Bacharela em Engenharia Ambiental pela Universidade de Sorocaba, desde 02/2018. Coautora dos artigos "Estudo de caso sobre possível contaminação do solo devido ao abandono de vagões no município de Iperó" e "Estudo de caso sobre o processo referente ao cemitério de vagões no município de Iperó", ambos aprovados e defendidos no XIII Congresso Nacional de Meio Ambiente em Poços de Caldas, em 09/2016. 


\section{JULIANA TOMAZ PACHECO LATINI}

Doutora e Mestre em Ciências Médicas pela UFF/Área Alimentos, Especialista em Nutrição Clínica, graduada em Nutrição pela mesma Universidade. Atualmente, professora das disciplinas Bromatologia, Análise de Alimentos e Toxicologia de Alimentos do Curso de Farmácia da UFRJ/Campus Macaé. Anteriormente, professora Colaboradora do Curso de Especialização em Segurança Nutricional e Qualidade de Alimentos da UGF e da Especialização em Nutrição Clínica da UFF, com experiência na área de Química de Alimentos/Bromatologia, Composição de Alimentos, Tecnologia de Alimentos, Análise Sensorial, Nutrição Experimental e Metodologia da Pesquisa. Experiente também em desnutrição e desenvolvimento fisiológico, embora, trabalhe, nos dias de hoje, com alimentos funcionais, fraudes e rotulagem de alimentos. Inglês fluente, francês intermediário e espanhol básico.

\section{JÚLIO FABRÍCIO SOARES FURTADO BELÉM}

Possui graduação em Administração com habilitação em Marketing pelo Centro Universitário do Norte (2003), especialização em Gerência de Projetos pelo Instituto de Dados da Amazônia (2011) e atualmente cursando Gestão de Negócios, Controladoria e Finanças Corporativas no Instituto de Pós-graduação de Goiás. Profissional com mais de 15 anos de experiência em vendas - entre os níveis operacional e tático - em empresas multinacionais e nacionais de diversos segmentos de mercado: medicamentos, alimentos, serviços, perfumaria e comunicação. Atua no presente como consultor empresarial na área de finanças.

\section{KÁTIA CALVI LENZI DE ALMEIDA}

Professora Adjunta de Patologia Geral na Faculdade de Medicina da Universidade Federal do Rio de Janeiro (UFRJ) e Professora colaboradora na Pós-graduação em Ciências Ambientais e Conservação da Universidade Federal do Rio de Janeiro (UFRJ). Concluiu o Doutorado em Patologia Geral pela Universidade Federal Fluminense (UFF) em 2011 e Mestrado em Patologia Geral nesta mesma Universidade (UFF) em 2007. Possui graduação em Fisioterapia pela Escola Superior de Ensino Helena Antipoff (Pestalozzi), em 2003. Tem experiência na área de Patologia, com ênfase em Patologia Experimental, Patologia Geral, Patologia Ambiental, Toxicologia e Nutrição Experimental. Publicou 14 artigos completos, 17 resumos expandidos em periódicos especializados, além de 93 trabalhos em congressos. Participou de 40 eventos nacionais e internacionais. Orienta 1 Dissertação de Mestrado. Orientou 1 Dissertação de Mestrado e 3 trabalhos de conclusão de curso. Co-orientou 2 Teses de Doutorado, 3 Dissertações de Mestrado e 6 trabalhos de conclusão de curso; nas áreas de Patologia Experimental, Nutrição Experimental e Ciências Ambientais e conservação. Recebeu 3 prêmios e/ou homenagens. Atualmente participa de 4 projetos de pesquisa e de 4 projetos de extensão. Tem publicado artigos em periódicos especializados do Chile, Espanha e Brasil. Em seu currículo Lattes os termos mais freqüentes na contextualização da produção científica, tecnológica e artístico-cultural são: Patologia, Linhaça, Sistema nervoso, Cantaxantina, Ácidos graxos ômega-3 e HIV/AIDS. Em 2012 recebeu o Prêmio Henri Nestlé em Saúde, com trabalho sobre a semente de linhaça e o sistema nervoso.

\section{KEVIN HARLEY FERREIRA MOURA}

Bacharelando em Ciências Náuticas, com especialização em Máquinas, no Centro de Instrução Almirante Braz de Aguiar - Escola de Formação de Oficiais da Marinha Mercante

\section{LÉO DA SILVA SAMPAIO}

Gestor ambiental pela Universidade Federal de Rondônia. Experiência em meio ambiente e Geoprocessamento. 


\section{LEONOR ALVES DE OLIVEIRA DA SILVA}

Possui mestrado em Química pela Universidade Federal de Mato Grosso do Sul(2001) e doutorado em Ciências Biológicas (Microbiologia Aplicada) pela Universidade Estadual Paulista Júlio de Mesquita Filho (2006). Atualmente é Professor Adjunto- Nivel I da Universidade Federal do Amazonas, Revisor de periódico da Acta Amazônica, professor adjunto da Universidade Federal de Pernambuco, Revisor de periódico da Igapó (CEFETAM), Membro de comitê assessor do Instituto federal da Amazônia e Professor da Universidade Federal da Paraíba. Tem experiência na área de Química, com ênfase em Química Orgânica. Atuando principalmente nos seguintes temas: Trichoderma inhamatum, xylanase, Fitoalexinas, Phytoalexin, soybean.

\section{LOURDES MANRESA CAMARGOS}

Engenheira Ambiental e Sanitarista, mestranda no Programa de Pós-graduação em Geografia do Instituto de Geociências - Universidade Federal de Minas Gerais (UFMG)

\section{LUCIANA ELER FRANÇA}

Engenheira Ambiental e atualmente mestranda do curso de Análise e Modelagem de Sistemas Ambientais. São doze anos de experiência em empresas com foco em projetos de licenciamentos ambiental, planos de fechamento de mina e estudos ambientais voltados para criação e plano de manejos de unidade de conservação e relocação de reserva legal. Possui MBA em Gerenciamento de Projetos, pós-graduação de Manejo de Florestas Nativas e especialização de Geoprocessamento.

\section{LUIZA CINTRA FERNANDES}

Atualmente Mestranda em Análise e Modelagem de Sistemas Ambientais, no Instituto de Geociências (IGC) da Universidade Federal de Minas Gerais (UFMG). Engenheira Ambiental pela Universidade Federal de Itajubá (UNIFEI) (2016). Foi bolsista CNPq de iniciação científica e bolsista do programa Ciências sem Fronteiras, fazendo graduação sanduíche na University of Brighton, Brighton, Inglaterra. Estagiou no Instituto Nacional de Pesquisas Espaciais (INPE) no Centro de Ciência do Sistema Terrestre (2010) e na Coordenação de Observação da Terra, na Divisão de Sensoriamento Remoto (2016)

\section{MAGALI CHRISTE CAMIMAROTA}

Professora Titular do Departamento de Engenharia Bioquímica da Escola de Química da Universidade Federal do Rio de Janeiro, com graduação em Engenharia Química pela EQ/UFRJ (1985), Mestrado em Tecnologia de Processos Químicos e Bioquímicos pela EQ/UFRJ (1991) e Doutorado em Bioquímica pelo IQ/UFRJ (1998). Ingressou como docente na Escola de Química em 1995, na qual atua no ensino de graduação e pós-graduação. Atua também no Programa de Mestrado Profissional em Engenharia Ambiental da Escola Politécnica e Escola de Química/UFRJ. Responsável pelo Laboratório de Tecnologia Ambiental da EQ/UFRJ, onde orienta pesquisas nos seguintes temas: tratamento biológico de efluentes industriais com ênfase em biorreatores anaeróbios e produção de biogás, processos híbridos de tratamento (enzimático/biológico) de efluentes industriais, tratamento de efluentes recalcitrantes e intensificação da produção de biogás a partir de lodos de esgoto, resíduos lignocelulósicos e biomassa algácea.

\section{MARCELA AMORIM DA SILVA}

Técnica em Química pelo Instituto Federal De Goiás. Graduanda em Farmácia na Universidade Federal de Goiás. 


\section{MARIA CAROLINE ALVES DE ALIMEIDA}

Graduada em Engenharia Ambiental pela Universidade de Sorocaba, atua na área de Gestão de Resíduos Sólidos e monitoramento da qualidade de água em reservatórios e poços artesianos. Co-autora dos artigos "Estudo de caso sobre possível contaminação do solo devido ao abandono de vagões no município de Iperó" e "Estudo de caso sobre o processo referente ao cemitério de vagões no município de Iperó", ambos aprovados e defendidos no XIII Congresso Nacional de Meio Ambiente em Poços de Caldas, em 09/2016

\section{MARIA ELIZA NAGEL HASSEMER}

Professora Adjunta do Departamento de Engenharia Sanitária e Ambiental - UFSC. Possui graduação em Engenharia Sanitária pela Universidade Federal de Santa Catarina - UFSC (1983), mestrado em Engenharia Ambiental pela UFSC (2000), doutorado em Engenharia Ambiental pela UFSC (2006), com parte realizada na Universidade do Minho, Portugal e posdoutorado pela UFSC (2008 e 2012).

\section{MARINA GRANHA VIEIRA}

Engenheira Ambiental pela Universidade Oswaldo Aranha de Volta Redonda-RJ.

\section{MARINA MATOS SOUTO}

Graduanda em Medicina pela Universidade Federal do Rio de Janeiro - Campus Macaé com início em 2016-2. Atualmente é bolsista de iniciação científica no projeto: Efeitos Toxicológicos da Cantaxantina Sobre a Prole de Camundongas Consumidoras de Truta Salmonada. Também atua como monitora pedagógica das disciplinas de Bioquímica Básica e de Fisiologia humana.

\section{MARTA MACIEL DUDUS}

Possui graduação em Medicina pela Faculdade de Medicina de Campos (1986) e Mestrado em Ciências Ambientais e Conservação pela Universidade Federal do Rio de Janeiro (UFRJ). Atualmente é Professora e Coordenadora de Pediatria da Universidade Federal do Rio de Janeiro-Campus Macaé, pediatra rotina da Unidade Intermediária Neonatal do Hospital Público Municipal de Macaé e pediatra ambulatorial da Prefeitura Municipal de Macaé. Tem experiência na área de Medicina, com ênfase em Saúde Materno-Infantil, atuando principalmente nos seguintes temas: pediatria, neonatologia e aleitamento materno.

\section{MAURÍCIO MARQUES PINTO DA SILVA}

Mestre e Doutor em Química pela Universidade de São Paulo, tem experiência na área química com ênfase em fisico-química. Coordenador de projetos de iniciação científica.

\section{MAURÍCIO MASARU DE SOUZA RIBEIRO}

Técnico Químico, estudante de Engenharia Química. Bolsista de iniciação científica com linha de pesquisa ambiental, na área de inibidores verdes de corrosão.

\section{MAXWEL COSTA DE AMORIM}

Possui graduação em Engenharia de Produção (2009) e especialização em Engenharia de Saúde e Segurança do Trabalho pelo Centro Universitário CESMAC e especialização lato sensu em Logística e Suplly Chain, mestrando em Análise de Sistemas Ambientais pelo Centro Universitário CESMAC. Atuou como consultor pelo Programa de Qualificação para a Exportação - PEIEX na Federação das Indústrias do Estado do Alagoas -FIEA / Casa da Industria Napoleão Barbosa. Atuou como instrutor técnico em Saúde e Segurança do 
Trabalho e Logística no Serviço de Aprendizagem Industrial SENAI/AI. Possui experiência na área de Engenharia de Produção, com ênfase em Engenharia Organizacional com foco em gestão de projetos; Engenharia de operações com foco em Projeto de Fábrica e de Instalações Industriais; LOGÍSTICA com foco na cadeia de suprimentos e sinergia de fluxos diretos e reversos, na ENGENHARIA DO TRABALHO e GESTÃO ESTRATÉGICA com foco na gestão de portfólio e engenharia da prevenção aliadas a qualidade e produtividade. Atua como diretor de operações industrial Aquaplus Ind e Comércio LTDA, diretos de logística na Aquaquímica Comércio de Produtos Químicos ME, consultor industrial, professor universitário, coordenador de pós-graduação lato sensu. Se destacou como $1^{\circ}$ colocado no vestibular 2005.1 CESMAC. (Engenharia de Produção). É lembrado no ramo industrial pela visão focada nos objetivos de crescimento organizacional e ampliação do mercado, redução e custos e sustentabilidade; Idealizador e executor do estudo referente ao tema "Integração entre as funções marketing e logística - Uma estratégia empresarial"; Idealizador e executor do estudo referente ao tema "Viabilidade logística X Qualidade de vida - Propulsores de produtividade e lucratividade - Uma visão estratégica. (Aplicabilidade e considerações das NR's 11 e 17)"; Idealizador e executor do estudo referente logística reversa por modelos lineares generalizados e como voluntário foi Diretor local do grupo de Escoteiros Vale do Paraíba $-4^{\mathrm{a}} \mathrm{AL}$.

\section{NAIARA MOTTIM JUSTINO}

Doutoranda em Engenharia Ambiental pela Universidade Federal de Santa Catarina. Mestre em Engenharia Ambiental pela Universidade Federal de Santa Catarina (2016). Graduada em Engenharia Ambiental pela Universidade Estadual do Centro-Oeste (2014).

\section{NATASHA CAMILO DA SILVA OLIVEIRA}

Tem experiência na área de Química, com ênfase em Química, e na área da saúde, com ênfase em Enfermagem.

\section{NEMÉSIO NEVES BATISTA SALVADOR}

Engenheiro Civil, UnB, 1974; Mestrado em Hidráulica e Saneamento, EESC/USP, 1979; Doutorado em Hidráulica e Saneamento, EESC/USP, 1990; Pesquisador Visitante e Pós Doutorado em Avaliação de Impactos Ambientais, Oxford Brookes University, 1998 - 1999; Engenheiro e Chefe de Divisão, CETESB, 1976 - 1980; Engenheiro de Projetos de Saneamento, IESA, 1980 - 1982; Professor Titular do Departamento de Engenharia Civil, UFSCar, 1982 - presente; Docente do Programa de Pós Graduação em Engenharia Urbana, UFSCar, 1994 - presente; Docente do Programa de Pós Graduação em Engenharia Civil, Universidade Federal de Uberlândia, 2014 - presente; Docente do Programa de Pós Graduação em Desenvolvimento Territorial e Meio Ambiente, Universidade de Araraquara, 2014 - presente.

\section{NIÉDJA SODRÉ DE ARAÚJO}

Doutoranda em Ciências Geodésicas na Universidade Federal do Paraná (UFPR/2018) com ênfase em Cartografia; Mestre em Engenharia Civil pela Universidade Federal da Bahia (UFBA) com ênfase em Sistema de Transportes e Informações Espaciais; Especialista em Geotecnologias pela Escola de Engenharia de Agrimensura da Sociedade Civil Educacional de Engenharia Eletro-Mecânica da Bahia (EEEMBA); Bacharel e Licenciada em Geografia, pelo Instituto de Geociências da UFBA, realiza pesquisa na área de cartografia inclusiva e cartografia aplicada aos estudos ambientais.

\section{PEDRO RODRIGUES BOZI FERRETE}

Bacharelando em Ciências Náuticas, com especialização em Máquinas, no Centro de Instrução Almirante Braz de Aguiar - Escola de Formação de Oficiais da Marinha Mercante 


\section{POLIANA ARRUDA FAJARDO}

Doutoranda e mestra em Engenharia Urbana pela Universidade Federal de São Carlos UFSCar, Especialista em Gestão Ambiental pela mesma universidade e graduada em Ciências Biológicas pela Universidade Estadual Paulista - UNESP, nas modalidades de Licenciatura e Bacharelado. Realiza pesquisas e estudos nas áreas de Ciências Ambientais e Saneamento. Seus principais temas de interesse são: gestão ambiental, meio ambiente, avaliação de impactos ambientais e sustentabilidade. Atua como revisora do periódico Revista Brasileira de Iniciação Científica, presta assessoria ad hoc para a avaliação de trabalhos científicos submetidos a eventos acadêmicos e ministra palestras acerca de temas ambientais.

\section{RAIANE FONSECA SILVA HERDY}

Médica residente em Clínica Médica na Prefeitura de Macaé, graduação em Medicina pela Universidade Federal do Rio de Janeiro Campus Macaé (UFRJ/ Macaé), plantonista no Hospital Público Municipal (Macaé) no setor de Terapia Intensiva. Participou do projeto de pesquisa intitulado: Efeitos toxicológicos da cantaxantina sobre a prole de camundongas consumidoras de truta salmonada.. Atuou como bolsista no projeto do Pró-PET Saúde; atuou como voluntária na monitoria da disciplina de Fisiologia e atuou como bolsista PIBIC no projeto de pesquisa intitulado: Papel dos astrócitos na diferenciação neuronal: efeitos da semente de linhaça (Linum usitatissimum).

\section{RENATA OLIVEIRA LUÍS}

Possui graduação em Farmácia pela Universidade José do Rosário Vellano (2011). Está cursando Gestão Pública pela Universidade Federal de Lavras com enfoque nas ações de vigilância sanitária e de saúde pública e Mestrado Profissionalizante em Sustentabilidade e Tecnologia Ambiental pelo Instituto Federal de Minas Gerais campus Bambuí com a linha de pesquisa Planejamento e Gestão Ambiental e enfoque na "Logística Reversa de Medicamentos". Atualmente é fiscal sanitário farmacêutica da Prefeitura Municipal de Bambuí/MG. Tem experiência na área de Farmácia, com atuação na Indústria Farmacêutica de medicamentos, cosméticos e alimentos; em farmácia clínica com atendimento de usuários do Sistema Único de Saúde (SUS); com Vigilância Sanitária; com educação em saúde contemplando desde atividades voltadas para o público profissional quanto para o público acadêmico.

\section{RENATA TEIXEIRA DE ALMEIDA MINHONI}

Possui graduação em Engenharia Ambiental pela Universidade Federal de Viçosa (2011) e mestrado em Engenharia Civil pela Universidade Federal de Viçosa (2013). Foi professora da Universidade do Sagrado Coração e coordenadora do curso de Engenharia Ambiental e Sanitária da Universidade do Sagrado Coração. Doutoranda em Agronomia (Irrigação e Drenagem), na linha de geoprocessamento, pela Universidade Estadual Paulista Júlio de Mesquita Filho (Unesp - Botucatu). Atualmente é professora substituta na Universidade Federal de São Carlos (UFSCar), Campus Lagoa do Sino.

\section{RICARDO LUIS LOURO BERBARA}

Possui graduação em Agronomia pela Universidade Federal Rural do Rio de Janeiro (UFRRJ1983), MSc Ciências do Solo pela UFRRJ (1989) e PhD em Biologia do Solo - University of Dundee, Escócia (1995). É professor convidado junto a Escuela de Graduados da Facultad de Agronomia da Universidad de Buenos Aires (UBA) desde 2004. Foi Coordenador do Programa de Pós-Graduação em Fitossanidade e Biotecnologia Vegetal Aplicada (2015-) e atual Chefe do Departamento de Solos (2014-). Tem experiência na área de Agronomia, com ênfase em Microbiologia e Bioquímica do Solo, atuando principalmente nos seguintes temas: ecologia e manejo do solo, micorriza e substâncias húmicas. Reitor UFRRJ (2017-). 


\section{SANDER LUIS STELAL}

Técnico de segurança do trabalho. Engenheiro Ambiental e especialista em Segurança do Trabalho.

\section{STÉFANY LARISSA DANTAS NASCIMENTO}

Bacharelando em Ciências Náuticas, com especialização em Máquinas, no Centro de Instrução Almirante Braz de Aguiar - Escola de Formação de Oficiais da Marinha Mercante

\section{TALES VINICIUS MARINHO DE ARAÚJO}

Mestre em Ciências e Meio Ambiente (Universidade Federal do Pará- UFPA). EspecialistaPós Graduação Lato Sensu- Educação Ambiental e Sustentabilidade (Universidade Cândido Mendes- UCAM). Graduado no Curso de Licenciatura em Ciências: Biologia e Química (Universidade Federal do Amazonas- UFAM). Trabalhou no período de Abril/ 2015 a Fevereiro/2017 como Professor de Magistério Superior - no Curso de Licenciatura em Ciências: Biologia e Química (Universidade Federal do Amazonas- UFAM). Professor Visitante de Pós Graduação Lato Sensu (Instituto de Apoio Superior do Norte- Educanorte), nos Cursos de Biologia e Química; Educação Física e Nutrição; Ensino de Matemática e Física e Ensino de Geografia; Educação Infantil. Professor visitante (FACULDADE BRASIL CENTRAL / CGESP), no curso de Gestão Escolar. Professor Ensino Básico- ÁREA: Ciências Naturais (Secretaria Municipal de Educação- SEMED. Professor visitante CENTRO DE EDUCAÇÃO TECNOLÓGICA DO AMAZONAS (CETAM).

\section{TÁLIS PEREIRA MATIAS}

Engenheiro Ambiental, Mestrando em Ciência e Engenharia Ambiental pela Universidade Federal de Alfenas (UNIFAL-MG), Campus Poços de Caldas. Instituto de Ciência e Tecnologia. Rodovia José Aurélio Vilela,BR 267, Km 533, 11999 - Cidade Universitária, Poços de Caldas - MG, 37715-400.

\section{TALITA VIEIRA MAYALD PRATA}

Engenheira Ambiental pela Universidade Federal de Alfenas (UNIFAL-MG), Campus Poços de Caldas. Instituto de Ciência e Tecnologia. Rodovia José Aurélio Vilela,BR 267, Km 533, 11999 - Cidade Universitária, Poços de Caldas - MG, 37715-400

\section{THIARA HELENA MOTA ALMEIDA}

Geografa pela Universidade Estadual de Santa Cruz, Mestranda do Programa de PósGraduação em Ciências e Tecnologias Ambientais da Universidade Federal do Sul da Bahia / Instituto Federal da Bahia, Campus Porto Seguro

\section{VÂNIA KELLY DA SILVA}

Graduanda em Fisioterapia na Faculdade dos Guararapes (FG). Tem experiência em microbiologia ambiental pelo Laboratório de Microbiologia Ambiental e Industrial (LAMAI) da Universidade Federal de Pernambuco (UFPE), no qual esteve vinculada como bolsista de iniciação científica no Departamento de Antibióticos (DANTI) no período entre 2014-2016.

\section{XIAOXIN WU}

Graduanda em Medicina pela Universidade Federal do Rio de Janeiro - Campus Macaé. Bolsista de iniciação científica no projeto de pesquisa intitulada: "Efeitos Toxicológicos da Cantaxantina Sobre a Prole de Camundongas Consumidoras de Truta Salmonada"; e também voluntária no projeto de extensão: " Atendimento ambulatorial da Liga Acadêmica de Cardiologia do Campus UFRJ Macaé Professor Aloísio Teixeira". Atuou como bolsista no projeto: "Acesso e Cuidado Integral a População LGBTT no Município de Macaé- RJ. 


\section{Agência Brasileira do ISBN}

ISBN 978-85-7042-053-4 IIIIIIIIIIIII

, $\left\|_{788570}\right\|_{420534} \|$

.

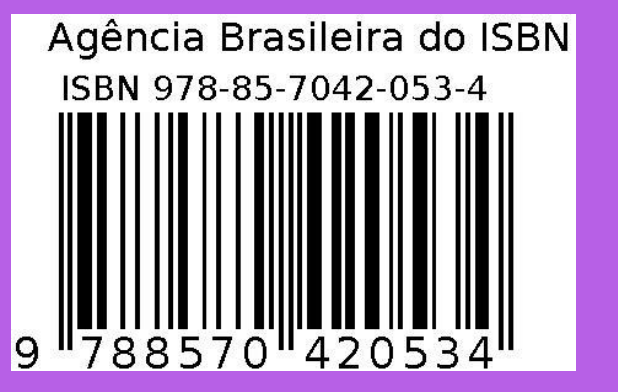

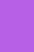

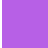
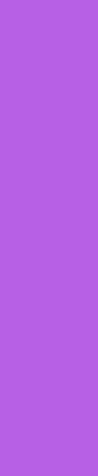